\title{
Analysis of International Efforts in Energy Research and Development
}

\section{Topical Report}

A. John Rezaiyan

R.T. Gill

September 1995

Work Performed Under Contract No.: DE-AC21-90MC27346

For

U.S. Department of Energy

Office of Environmental Management

Office of Technology Development

Washington, DC
U.S. Department of Energy Office of Fossil Energy Morgantown Energy Technology Center Morgantown, West Virginia

By

K\&M Engineering and Consulting Corporation

Washington, DC 20036

DISTRIBUTON OF TIS DOCUMENT IS UNLMTED
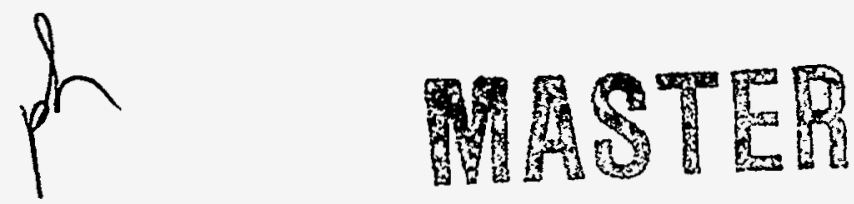


\section{DISCLAIMER}

This report was prepared as an account of work sponsored by an agency of the United States Government. Neither the United States Government nor any agency thereof, nor any of their employees, makes any warranty, express or implied, or assumes any legal liability or responsibility for the accuracy, completeness, or usefulness of any information, apparatus, product, or process disclosed, or represents that its use would not infringe privately owned rights. Reference herein to any specific commercial product, process, or service by trade name, trademark, manufacturer, or otherwise does not necessarily constitute or imply its endorsement, recommendation, or favoring by the United States Government or any agency thereof. The views and opinions of authors expressed herein do not necessarily state or reflect those of the United States Government or any agency thereof.

This report has been reproduced directly from the best available copy.

Available to DOE and DOE contractors from the Office of Scientific and Technical Information, 175 Oak Ridge Turnpike, Oak Ridge, TN 37831; prices available at (615) 576-8401.

Available to the public from the National Technical Information Service, U.S. Department of Commerce, 5285 Port Royal Road, Springfield, VA 22161; phone orders accepted at (703) 487-4650. 



\section{Analysis of International Efforts in Energy Research and Development}

\section{Topical Report}

A. John Rezaiyan

R.T. Gill

Work Performed Under Contract No.: DE-AC21-90MC27346

U.S. Department of Energy Office of Environmental Management Office of Technology Development 1000 Independence Avenue Washington, DC 20585
For

U.S. Department of Energy Office of Fossil Energy Morgantown Energy Technology Center P.O. Box 880 Morgantown, West Virginia 26507-0880

By

K\&M Engineering and Consulting Corporation

2001 L. Street, NW, Suite 500

Washington, DC 20036 


\section{Contents}

Executive Summary vii

1. Introduction 1

1.1. Background 1

1.2. Research and Development Definitions 2

$\begin{array}{ll}\text { 1.2.1. Applications } & 2\end{array}$

1.2.2. Funding Sources 3

1.2.3. Currency Conversion 3

1.2.4. Distribution 4

1.2.5. Fuel Cells 4

1.2.6. Advanced Gas Turbines 6

1.3. Report Structure $\quad 8$

2. Methodology 9

2.1. Literature Review 10

2.2. Country Selection 10

2.3. Data Collection 11

2.4. Data Analysis 12

2.4.1. Public Expenditures 12

$\begin{array}{ll}\text { 2.4.2. Private Expenditures } & 13\end{array}$

3. Research and Development Expenditures 15

3.1. World R\&D Expenditures 15

3.1.1. Total Expenditures 15

3.1.2. Expenditures As a Percentage of GDP 18

3.1.3. Average Annual Percentage Change in R\&D Funding 18

$\begin{array}{ll}3.2 \text { Energy } & 19\end{array}$

3.2.1. Total Expenditures 20

3.2.2. Expenditures As a Percentage of GDP 21

3.2.3. Average Annual Percentage Change in R\&D Expenditures 22

3.2.4. Expenditures As a Percentage of Total R\&D Expenditures 22

3.3. Fossil Fuel 23

3.3.1. Total Expenditures 24

3.3.2. Expenditures As a Percentage of GDP 25

3.3.3. Average Annual Percentage Change in R\&D Expenditures 26

3.3.4. Expenditures As a Percentage of Total R\&D Expenditures 27

$\begin{array}{ll}3.4 \text { Fuel Cell } & 28\end{array}$

3.4.1. Summary 28

3.4.2. Total Expenditures 31

3.4.3. Expenditures As a Percentage of GDP 32

3.4.4. Expenditures As a Percentage of Total R\&D Expenditures 33

3.4.5. Trends in Expenditures 34 
3.4.6. Public and Private Contributions $\quad 35$

3.5 Advanced Gas Turbine $\quad 35$

3.5.1. Summary 36

3.5.2. Total Expenditures 38

3.5.3. Expenditures As a Percentage of GDP 39

3.5.4. Expenditures As a Percentage of Total R\&D Expenditures 39

3.5.5. Trends in Expenditures 41

3.5.6. Public and Private Contributions 41

4. Country Reports $\quad 42$

4.1. Australia $\quad 43$

4.2. Belgium 47

4.3. Canada 51

4.4. Denmark 56

4.5. Finland 61

4.6. France 65

4.7. Germany 71

4.8. Italy $\quad 80$

4.9. Japan $\quad 85$

4.10. Netherlands $\quad 95$

4.11. Norway 100

$\begin{array}{ll}\text { 4.12. Sweden } & 104\end{array}$

4.13. Switzerland 110

4.14. United Kingdom $\quad 115$

4.15. United States $\quad 125$

4.16. European Union 137

$\begin{array}{ll}\text { 5. Conclusions } & 141\end{array}$

$\begin{array}{ll}\text { References } & 143\end{array}$

$\begin{array}{ll}\text { Appendices } & 144\end{array}$

A. R\&D Expenditures Database $\quad 145$

B. Fuel Cell Database $\quad 150$

C. Advanced Gas Turbine Database 165

D. Exchange Rates and Purchasing Power Parities 173

$\begin{array}{ll}\text { E. Further Reading } & 174\end{array}$ 


\section{Tables}

Summary

1.1. Major Fuel Cell Types and Significant Differences 5

1.2. Current Gas Turbine Performan 7

3.1. Estimated 1994 R\&D Expenditures for Selected Countries 17

3.2. Major Fuel Cell Funding Organizations by Country 29

4.1. Fuel Cell Project List for Australia 46

4.2. Advanced Gas Turbine Project List for Australia 46

4.3. Fuel Cell Project List for Belgium 50

4.4. Advanced Gas Turbine Project List for Belgium 50

4.5. Fuel Cell Project List for Canada 54

4.6. Advanced Gas Turbine Project List for Canada 55

4.7. Fuel Cell Project List for Denmark 59

4.8. Advanced Gas Turbine Project List for Denmark 60

4.9. Fuel Cell Project List for Finland 63

4.10. Advanced Gas Turbine Project List for Finland 64

4.11. Fuel Cell Project List for France 68

4.12. Advanced Gas Turbine Project List for France $\quad 70$

4.13. Fuel Cell Project List for Germany 74

4.14. Advanced Gas Turbine Project List for Germany 77

4.15. Fuel Cell Project List for Italy 83

4.16. Advanced Gas Turbine Project List for Italy 84

4.17. Fuel Cell Project List for Japan 90

4.18. Advanced Gas Turbine Project List for Japan 93

4.19. Fuel Cell Project List for the Netherlands 98

4.20. Advanced Gas Turbine Project List for the Netherlands 99

4.21. Fuel Cell Project List for Norway 102

4.22. Advanced Gas Turbine Project List for Norway 103

4.23. Fuel Cell Project List for Sweden 107

4.24. Advanced Gas Turbine Project List for Sweden 109

4.25. Fuel Cell Project List for Switzerland 113

4.26. Advanced Gas Turbine Project List for Switzerland 114

4.27. Fuel Cell Project List for the United Kingdom 119

4.28. Advanced Gas Turbine Project List for the United Kingdom 123

4.29. Fuel Cell Project List for the United States 131

4.30. Advanced Gas Turbine Project List for the United States 135

4.31. Fuel Cell Project List for the European Union 140

D.1. Exchange Rates and Purchasing Power Parities 173 


\section{Figures}

1.1. Fuel Cell Schematics 5

2.1. Methodology 9

2.2. Countries Selected 11

2.3. Data Analysis Flow Chart 13

2.4. Estimation of Privately Funded R\&D Expenditures 14

3.1. Worldwide R\&D Funding Levels 16

3.2. 1994 R\&D As a Percentage of GDP 18

3.3. Annual Percentage Change in R\&D Funding 19

3.4. 1994 World Energy R\&D Expenditures 20

3.5. 1994 World Energy R\&D As a Percentage of GDP 21

3.6. Average Annual Rate of Change in Energy R\&D Funding 22

3.7. 1994 Energy R\&D Funding As a Percentage of Total R\&D Funding 23

3.8. 1994 World Fossil Fuel R\&D Expenditures 24

3.9. 1994 World Fossil Fuel R\&D As a Percentage of GDP 25

3.10. Average Annual Rate of Change in Fossil Fuel R\&D Expenditures 26

3.11. 1994 Fossil Fuel Funding As a Percentage of Total R\&D Expenditures 27

3.12. 1994 World Fuel Cell R\&D Expenditures 32

3.13. 1994 World Fuel Cell R\&D As a Percentage of GDP 33

3.14. 1994 Fuel Cell R\&D Funding As a Percentage of Total R\&D Expenditures 34

3.15. Public and Private Contributions to Fuel Cell R\&D Expenditures 35

3.16. Advanced Gas Turbine Cooperation 36

3.17. 1994 World Advanced Gas Turbine R\&D Expenditures 38

3.18. 1994 World Advanced Gas Turbine R\&D As a Percentage of GDP 40

3.19. 1994 World Advanced Gas Turbine R\&D Funding As a Percentage of Total R\&D Expenditures

3.20. Public and Private Contributions to Advanced Gas Turbine R\&D Funding 41

4.1. Selected Countries 42

4.2. Australian R\&D Expenditures 43

4.3. Breakdown of Australian Energy R\&D and Electricity Generation 45

4.4. Belgian R\&D Expenditures 47

4.5. Breakdown of Belgian Energy R\&D and Electricity Generation 49

4.6. Canadian R\&D Expenditures 51

4.7. Breakdown of Canadian Energy R\&D and Electricity Generation 53

4.8. Danish R\&D Expenditures 56

4.9. Breakdown of Danish Energy R\&D and Electricity Generation 58

4.10. Finnish R\&D Expenditures 61

4.11. Breakdown of Finnish Energy R\&D and Electricity Generation 62

4.12. French R\&D Expenditures 65

4.13. Breakdown of French Energy R\&D and Electricity Generation 67

4.14. German R\&D Expenditures $\quad 71$

4.15. Breakdown of German Energy R\&D and Electricity Generation. 73

4.16. Italian R\&D Expenditures $\quad 80$ 
4.17. Breakdown of Italian Energy R\&D and Electricity Generation 82

4.18. Japanese R\&D Expenditures 85

4.19. Breakdown of Japanese Energy R\&D and Electricity Generation 87

4.20. Dutch R\&D Expenditures 95

4.21. Breakdown of Dutch Energy R\&D and Electricity Generation 97

4.22. Norwegian R\&D Expenditures 100

4.23. Breakdown of Norwegian Energy R\&D and Electricity Generation 101

$\begin{array}{ll}\text { 4.24. Swedish R\&D Expenditures } & 104\end{array}$

4.25. Breakdown of Swedish Energy R\&D and Electricity Generation 106

4.26. Swiss R\&D Expenditures 110

4.27. Breakdown of Swiss Energy R\&D and Electricity Generation 112

4.28. British R\&D Expenditures $\quad 115$

4.29. Breakdown of British Energy R\&D and Electricity Generation 118

4.30. American R\&D Expenditures 125

4.31. Breakdown of American Energy R\&D and Electricity Generation 127

4.32. European Union R\&D Expenditures 137

4.33. Breakdown of European Union Energy R\&D and Electricity Generation 139 


\section{Executive Summary}

Research and experimental development comprise innovative and creative work undertaken systematically to increase the stock of knowledge of science, engineering, and society. This knowledge reserve is used to improve living conditions and standards, including economic growth. Research and development (R\&D) expenditures are useful measures of the scale and direction of technological innovation within a country, industry, or scientific field. Administrators concerned with economic growth and performance rely on $R \& D$ statistics as one possible type of indicator of technological change. R\&D statistics are an essential tool in many government programs and evaluations (OECD 1993).

$\mathrm{K} \& M$ Engineering and Consulting Corporation analyzed international $R \& D$ efforts under a task order with the Morgantown Energy Technology Center (METC) of the U.S. Department of Energy (USDOE) from September 1994 through May 1995. The objective of the analysis was to identify and evaluate R\&D funding sources, levels, and trends in the energy sectors of selected industrialized countries (Australia, Belgium, Canada, Denmark, Finland, France, Germany, Italy, Japan, Netherlands, Norway, Sweden, Switzerland, United Kingdom, United States) and the European Union (EU). Fossil fuel technologies, particularly fuel cells and advanced gas turbines, were the focus of the analysis, whose results are presented in this report.

\section{Introduction and Background}

R\&D programs in the energy sector include conservation, fossil fuel, new energy sources, nuclear, electricity, and energy systems analysis. Fossil fuel R\&D-related programs, as classified by the International Energy Agency (IEA), include enhanced oil and gas recovery; oil and gas refining and transportation; oil shale and tar sands; and coal production, preparation, transport, combustion, and conversion (IEA 1993). Fuel cell and advanced gas turbine $R \& D$ are classified under fossil fuel, energy efficiency, energy conservation, or new energy sources. Fuel cell programs focus on alkaline, phosphoric acid, solid oxide, molten carbonate, polymer electrolyte, and direct methanol technologies. Advanced gas turbine programs concentrate on ultra-high efficiency; environmental superiority; cost competitiveness; fuel flexibility; and reliability, availability, and maintainability (RAM) (USDOE 1993).

Fuel cells are innovative technologies for the efficient and environmentally superior generation of electricity, based on the electrochemical oxidation of a fuel. Because fuel cells do not utilize the combustion reaction, environmentally-restricted combustion 
byproduct gases $\left(\mathrm{NO}_{x}, \mathrm{SO}_{\mathrm{x}}\right)$ are not produced. Also, fuel cells are not efficiency limited by the carnot cycle. Currently, fuel cells are cost prohibitive for commercial applications.

The United States, Japan, Canada, and Europe engage in fuel cell R\&D. The United States and Japan have had, historically, the most significant fuel cell programs and have supplied the vast majority of demonstrated fuel cell stacks. European expenditures in basic and applied research have increased extensively over the past several years. Canada has a large, privately-supported program. Phosphoric acid fuel cells (PAFCs) are the only commercially available fuel cells and have been demonstrated at 11-MW in Japan. Molten carbonate fuel cells (MCFCs) are now operational and are scheduled for demonstration at the 2-MW level in Santa Clara, California. Solid oxide fuel cells (SOFCs) are at the basic research stage and are the technology in which Europe has competed. Polymer electrolyte fuel cells (PEFCs) are the primary technology used in the automotive industry and have the highest current level of R\&D expenditures.

Advanced gas turbines programs support technologies for the production of electric power through the highly efficient combustion of a feed gas. Feed gas consists primarily of hydrogen, methane, carbon monoxide, ethylene, ethane, and lower levels of propylene, propane, butane, and pentane. It can be natural gas or syngas from the gasification of coal or biomass. Gas turbines have the advantage of higher single-cycle efficiency and combined-cycle efficiency than other power generation technologies while retaining an affordable cost and RAM competitive with current standards. Such private corporations as General Electric (GE), Asea Brown Boveri (ABB), Seimens, Rolls Royce, and United Technologies provide the majority of funding. Government funding levels are minimal by comparison.

\section{Summary of Results}

R\&D expenditures in energy, fossil fuel, fuel cells, and advanced gas turbines were collected and analyzed. Table S-1 shows 1994 estimates for the selected countries.

The analysis showed that the United States and Japan provide approximately two-thirds of total R\&D funding. Germany, France, United Kingdom, and Italy also maintain large $R \& D$ budgets. Japan leads the world in funding energy, fossil fuel, and fuel cell $R \& D$, allocating an estimated US $\$ 30.5$ billion to energy R\&D in 1994 (approximately $75 \%$ of the total expenditures of the selected countries). Japan provided more than $50 \%$ of the total fossil-fuel R\&D funding in the selected countries and about $40 \%$ of the total fuel cell funding. American and British private corporations dominated advanced gas turbine $R \& D$ funding. 
1994 funding for fuel cell R\&D escalated to an estimated level exceeding US $\$ 500$ million throughout the world. This funding is provided by Japan, the U.S., Canada, and Europe.

Table S-1. Estimated 1994 R\&D Expenditures for Selected Countries (US\$ million)

\begin{tabular}{|l|l|l|l|l|l|l|}
\hline Country & $\begin{array}{l}\text { GDP } \\
\text { (US\$llion) }\end{array}$ & Total & Energy & $\begin{array}{l}\text { Fossil } \\
\text { Fuel }\end{array}$ & $\begin{array}{l}\text { Fuel } \\
\text { Cell }\end{array}$ & $\begin{array}{l}\text { Advanced } \\
\text { Gas } \\
\text { Turbine }\end{array}$ \\
\hline Australia & 280,900 & $4,984.4$ & 167.7 & 41.6 & 1.0 & 0.0 \\
\hline Belgium & 211,300 & $3,562.1$ & 117.9 & 117.9 & 2.25 & 0.0 \\
\hline Canada & 537,400 & $6,869.5$ & 945.2 & 285.3 & 32.1 & 0.1 \\
\hline Denmark & 137,700 & $2,634.1$ & 139.2 & 25.3 & 8.5 & 0.0 \\
\hline $\begin{array}{l}\text { European } \\
\text { Union }\end{array}$ & 248,800 & $5,224.0$ & 491.0 & 39.3 & 11.1 & 0.0 \\
\hline Finland & 70,000 & $3,188.3$ & 206.0 & 24.9 & 0.5 & 0.0 \\
\hline France & $1,269,800$ & $36,175.3$ & $1,137.5$ & 76.7 & 12.0 & 22.9 \\
\hline Germany & $1,790,000$ & $53,470.2$ & $1,005.4$ & 73.4 & 53.1 & 68.3 \\
\hline Italy & 959,100 & $16,332.9$ & 636.8 & 184.7 & 29.7 & 0.1 \\
\hline Japan & $4,757,800$ & $163,506.9$ & $30,493.7$ & $2,369.0$ & 203.8 & 129.0 \\
\hline $\begin{array}{l}\text { Nether- } \\
\text { lands }\end{array}$ & 317,600 & $6,151.2$ & 310.6 & 24.8 & 16.2 & 5.0 \\
\hline Norway & 102,400 & $1,967.3$ & 93.6 & 22.5 & 3.9 & 0.0 \\
\hline Sweden & 173,600 & $5,477.0$ & 172.1 & 1.0 & 3.0 & 116 \\
\hline $\begin{array}{l}\text { Switzer- } \\
\text { land }\end{array}$ & 237,000 & $6,622.6$ & 547.0 & 47.8 & 3.0 & 116 \\
\hline UK & 927,000 & $17,810.0$ & 408.1 & 40.8 & 12.0 & 509.5 \\
\hline US & $6,579,500$ & $169,809.2$ & $4,751.2$ & 700.3 & 150.5 & 520.5 \\
\hline
\end{tabular}


The Japanese fuel-cell R\&D program is federally funded under the New Sunshine program of the Ministry of International Trade and Industry, managed by the New Energy and Industrial Techology Development Organization (NEDO) and the Agency of Natural Resources and Energy. Two-thirds of total Japanese fuel-cell R\&D funding is provided by such Japanese utilities as Tokyo Electric Power Company (TEPCO), Kansai Electric Power Company, Chubu Electric Power Company, Tohoku Electric Power Company, and Tokyo Gas, as well as private corporations, including Fuji, Hitachi, Mitsubishi, Sanyo, and Ishikawajima-Harima Heavy Industries (IHI).

The U.S. fuel-cell R\&D program is funded primarily through the federal government. The USDOE, Department of Defense (DOD), and the National Aeronautics and Space Administration (NASA) provided funding for fuel-cell R\&D in 1994. Private expenditures are provided by MC Power, International Fuel Cells, Energy Research Corporation, Westinghouse, Allied Signal, H Power, and EP Fuel Cells. The Electric Power Research Institute and the Gas Research Institute allocates additional funding.

Canada's large fuel-cell R\&D program is concentrated within that of Ballard Power Systems, which focuses on development of PEFCs. Germany, Italy, Netherlands, United Kingdom, Denmark, and the EU provide the bulk of European fuel-cell R\&D funding. Of these, Germany has the largest program, which is supported by such private companies as Daimler Benz, BMW, Seimens, and Dornier. Italy has the second largest European program, whose primary participants are Ansaldo, Fiat, and DeNora. The UK's program is well developed; however, most projects are either basic research or partially supported by EU programs. As a result, the funding level of US\$12 million does not accurately reflect the program size of at least 29 projects. UK leaders in the fuel-cell effort are Johnson Matthley, British Gas, AEA Technology, CJB, VSEL, and Rolls Royce. The Dutch program focuses on development of MCFC and the work of the company BCN. Denmark, through the programs of ELSAM, Haldor Topsoe, and the Riso Research Center, is ambitious in investigating MCFC and SOFC.

Advanced gas turbine $\mathrm{R} \& \mathrm{D}$ is dominated by the work of large, private, multinational corporations. Although funding data is unavailable, estimations provide a picture of the funds available for gas turbine R\&D within a corporation. GE, determined the world's leader in advanced gas turbine $R \& D$, has a large $R \& D$ budget and a great deal of available financial resources. Rolls Royce was estimated to have the second largest advanced gas turbine $R \& D$ budget, followed by $A B B$, United Technologies, and Siemens. Additional funding is provided by Kawasaki, European Gas Turbines, Solar Turbines, Hitachi, Westinghouse, IHI, Toshiba, and Mitsubishi. The U.S. and UK are home to three of the four as well as five of the ten largest gas turbine R\&D companies in the world. As a result, these two countries are determined to have the highest level of R\&D support for gas turbine $R \& D$. ABB funding is split between Sweden and Switzerland. Siemens is headquartered in Germany. Japanese advanced gas turbine expenditures include those of Hitachi, Kawasaki, Toshiba, IHI, and Mitsubishi. 
Government expenditures throughout the selected countries ranged from 0 to $100 \%$ of the total advanced gas turbine R\&D expenditures. The federal governments of the United States (US\$ 32 million), Japan (US\$25.2 million), France (US\$ 5.25 million), Germany (US\$ 4.42) and the Netherlands (US\$ 3 million) had the largest absolute levels of advanced gas turbine R\&D expenditures of the selected countries. As a percentage of total advanced gas turbine $R \& D$, government $R \& D$ expenditures in the Netherlands (60\%) were the highest followed by France (22.9\%), Japan (19.5\%), Germany (6.5\%), and the United States (6.2\%).

\section{Conclusions}

Analysis of R\&D expenditures as a percentage of gross domestic product (GDP), spending trends, and percentage of public and private funding resulted in the following conclusions:

- U.S. levels significantly trail those of Japan for energy, fossil fuel, and fuel cell.

- US. Private-sector support is much lower than that of Japan.

- As a percentage of GDP, U.S. expenditures are considerably lower than those of Japan for all areas except advanced gas turbines.

- U.S. and Japanese federal governments and Japanese utilities provide most of the world's support for fuel-cell R\&D.

- PEFC programs in Europe (Daimler Benz, BMW, Fiat) and Canada (Ballard) are rapidly increasing to levels competitive with the U.S. and Japan.

- Of the primary fuel-cell types, PEFC receives the highest level of R\&D funding.

- American, British, Swedish, German, Swiss, and Japanese private companies provide the majority of advanced gas turbine R\&D funding.

Of the selected countries, Japan allocated three-quarters of the total energy R\&D funding. Energy R\&D in Japan focused on nuclear technologies, particularly fusion projects. Although Japan did not place a high priority on fossil-fuel R\&D, the country's budget was more than $300 \%$ greater than that of the U.S. Japan and the U.S. accounted for approximately 38 and $28 \%$, respectively, of the total fuel-cell R\&D funding. GE, Westinghouse, Rolls Royce, United Technologies, ABB, and Siemens provided the majority of funding for advanced gas turbines. 
Although the U.S. R\&D program is among the largest of the selected countries, as a percentage of GDP, the level of U.S. expenditures is significantly less than that of a number of the selected countries. Total U.S. R\&D expenditures as a percentage of GDP were slightly higher than the average of the selected countries; however, energy, fossil fuel, fuel cell, and advanced gas turbine expenditures, as a percentage of GDP, were lower. Finland, Sweden, and Japan had the highest levels of total R\&D expenditures as a percentage of GDP. Japan's energy R\&D expenditure, as a percentage of GDP, was more than nine times the U.S. level. The high level of expenditures as a percentage of GDP was consistent throughout Japan's fossil fuel and fuel cell programs. Denmark and the Netherlands had the highest level of fuel-cell R\&D expenditures as a percentage of GDP. Sweden, Switzerland, and the UK had the highest level of R\&D expenditures as a percentage of GDP for advanced gas turbines.

Overall, total R\&D funding increased over the past several years. In particular, the levels of R\&D funding in Finland; Italy, Japan, and Australia increased at average annual percentages of about $10 \%$ or more. In contrast, overall energy $R \& D$ and fossil fuel $R \& D$ funding decreased. The UK, which abolished its Department of Energy in 1992, decreased energy and fossil-fuel R\&D funding at an average annual rate of $14 \%$ over the past several years. Italy and Belgium significantly reduced their energy R\&D expenditures, while the energy and fossil fuel R\&D funding in Denmark, Finland, Japan, and Switzerland has increased since 1990. Fuel-cell R\&D funding has increased over the past several years. A 1992 estimate by the EU indicated total European expenditures at US\$ 64 million (Michael 1994). The 1994 estimated expenditure level in Europe was approximately US\$155 million. Notable growth occurred in most of the fuel cell programs in Europe, particularly those of Germany and Italy. A 1993 estimate indicated a total fuel-cell R\&D funding level of more than US $\$ 400$ million compared to the 1994 estimated expenditures of US\$543 million. Advanced gas turbine R\&D expenditures have likely been at the high levels estimated for 1994 over the past several years.

Japan's private sector supplies $83 \%$ of the country's total R\&D funding. In the U.S., the private sector supplies $52 \%$. In Germany and the UK, the private sector supplies about $60 \%$ of R\&D funding; for Italy and France, private support is about $50 \%$. In fuel cells, Japan's government expenditures were approximately US\$68 million compared to USDOE and DOD expenditures of US\$87.2 million. However, because of Japan's high level of private sector support, total fuel-cell expenditures in the U.S. trail those of Japan by US $\$ 53$ million. To remain competitive in fuel cell $R \& D$, expenditures must increase to levels equivalent to those of Japan. For advanced gas turbine R\&D, the private sector provides approximately $95 \%$ of total funding of the selected countries. 


\section{Introduction}

From September 1994 through April 1995, K\&M Engineering and Consulting Corporation conducted an analysis of international R\&D efforts for the Morgantown Energy Technology Center (METC) of the USDOE (under contract no. DE-AC2190MC27346, task order no. 27). The objective of the analysis was to identify and evaluate R\&D funding sources, levels, and trends for the energy sectors of selected industrialized countries (Australia, Belgium, Canada, Denmark, Finland, France, Germany, Italy, Japan, Netherlands, Norway, Sweden, Switzerland, United Kingdom, and United States), as well as the European Union (EU). Fossil fuel R\&D technologies, particularly fuel cells and advanced gas turbines, were the focus within the energy sector.

\subsection{Background}

Research and experimental development comprise innovative work undertaken systematically to increase the stock of knowledge in science, engineering, and society. This knowledge is used to devise new applications. R\&D expenditures are useful measures of the scale and direction of technological innovation with a country, industry, or scientific field. Administrators concerned with economic growth and performance rely on $R \& D$ statistics as an indicator of technological change. $R \& D$ statistics are an essential tool in many government programs and evaluations (OECD 1993).

Energy R\&D is comprised of energy conservation, fossil fuel, new energy sources, nuclear, electricity, and energy systems analysis. Fossil fuel R\&D programs are divided into enhanced oil and gas recovery; oil and gas refining and transportation; oil shale and tar sands; and coal production, preparation, transport, combustion, and conversion (IEA 1993). Fuel cell and advanced gas turbine R\&D is classified under the following energy R\&D divisions: fossil fuel, energy efficiency, energy conservation, or new energy sources. Fuel cell R\&D programs focused on alkaline, phosphoric acid, solid oxide, molten carbonate, polymer electrolyte, and direct methanol technologies. Advanced gas turbine R\&D emphasized ultra-high efficiency, environmental superiority, cost competitiveness, fuel flexibility, and reliability, availability, and maintainability (RAM) (USDOE 1993).

Fuel cells are technologies for the efficient and environmentally-superior generation of electricity based on the electrochemical oxidation of a fuel. Because fuel cells do not utilize the combustion reaction, environmentally restricted combustion byproduct gases $\left(\mathrm{NO}_{x}, \mathrm{SO}_{x}\right)$ are not produced and efficiency is not limited by the carnot cycle. Currently, fuel cells are cost prohibitive for commercial applications. 
The U.S., Japan, Canada, and Europe engage in fuel cell R\&D. Most demonstrated fuel cell stacks have been supplied by American or Japanese vendors. European expenditures in basic and applied fuel-cell research have increased extensively over the past several years. Canada has a large, privately-supported fuel cell program.

PAFCs are commercially available and have been demonstrated at $11 \mathrm{MW}$ in Japan. MCFCs are now operational and scheduled for demonstration at a 2-MW facility in Santa Clara, California. SOFCs are at the basic research stage. European SOFC programs are competitive with those of the U.S. and Japan. PEFCs are the primary technology for use in the automotive industry and have the highest current level of $R \& D$ expenditures.

Advanced gas turbine programs support technologies for generating electricity through the highly-efficient and environmentally clean combustion of a feed gas. Feed gas consists primarily of hydrogen, methane, carbon monoxide, ethylene, ethane, and lower levels of propylene, propane, butane, and pentane. It can be natural gas or syngas from the gasification of coal or biomass. Gas turbines have the advantage of higher singlecycle and combined-cycle efficiency than other power generation technologies, while retaining an affordable cost and RAM competitive with current standards. Such private corporations as GE, ABB, Seimens, Rolls Royce, and United Technologies provide the majority of funding. Government funding levels are minimal compared to those of private corporations.

\subsection{Definitions}

The following section defines R\&D classifications; funding sources; and performance institutions, currency conversion methods; and energy, fossil fuel, fuel cell, and advanced gas turbine R\&D. These definitions were used throughout the data collection and analysis and report preparation.

\subsubsection{R\&D Applications}

R\&D expenditures are classified into the following primary applications (OECD 1993):

- Basic Research. Experimental or theoretical work undertaken primarily to acquire new knowledge of the underlying foundation of phenomena and observable facts, without any particular applications or use in view. 
- Applied Research. Original investigation undertaken to acquire new knowledge directed primarily toward a specific objective.

- Experimental Development. Systematic work, drawing on existing knowledge gained from research or practical experience directed to producing new materials, products or devices; installing new processes, systems and services; or substantially improving those already produced or installed.

- Non R\&D Activities. Education and training, non-R\&D industrial activities, and administration and support.

\subsubsection{R\&D Funding Sources}

R\&D funding is provided by various institutions grouped as follows: private (industrial); public (governmental); and other national sources, such as higher education and nonprofit organizations. For the purposes of this report, all funding sources considered were either public or private. Public sources included all government agencies, research centers, and national labs funded solely by the national government. Private sources included all private corporations, research centers, utilities, and associations and organizations whose majority of dues-paying members are private corporations or utilities.

\subsubsection{Currency Conversion}

Foreign currency was converted to U.S. dollars by two methods: (1) the exchange rate(ER) and (2) purchasing power parity (PPP).

- Exchange Rate: Standard proportion utilized to exchange currencies among countries published daily in major periodicals. (For the purposes of this report exchange rates from December 1994 were used)

- Purchasing Power Parity: Integrates the current currency ERs, as well as the relative differences in the cost of a basket of goods from country to country. PPPs are available on a quarterly basis through the IEA of the OECD. (For the purposes of this report PPP's from the 4th quarter of 1994 were used)

PPPs are commonly used to compare expenditures within countries. Their obvious advantage for currency conversion is that they serve to normalize expenditures with the cost of living within a specific country. However, PPPs do not account for the purchase of goods outside the country of interest or the sales of goods in foreign currencies. Therefore, PPPs allow for the assessment of the relative importance of an expenditure in 
relation to cost of living but do not allow for the absolute comparison of the size of a project supported by a given expenditure.

\subsubsection{R\&D Distribution}

R\&D expenditures are divided into many categories. Those focused on in this report are total R\&D, energy, fossil fuel, fuel cell, and advanced gas turbine. Total, energy, and fossil fuel R\&D are defined below. Fuel cell and advanced gas turbine R\&D expenditures are defined in sections 1.2 .5 and 1.2.6, respectively.

- Total R\&D: Sum of all R\&D programs within a country.

- Energy R\&D: Sum of all energy-related R\&D programs within a country, including conservation, fossil fuel, new energy sources, nuclear, electricity, and energy systems analysis.

- Fossil Fuel R\&D: Sum of all fossil fuel-related R\&D programs within a country, including enhanced oil and gas recovery; oil and gas refining and transport; oil shale and tar sands; and coal production, preparation, transport, combustion, and conversion.

The divisions within energy and fossil fuel categories are consistent with the divisions utilized by the IEA of the OECD (IEA 1993).

\subsubsection{Fuel Cells}

The following definition of fuel cells helped determine whether an R\&D project should be included in the overall database of fuel-cell $R \& D$ expenditures. All R\&D projects (basic and applied research or experimental development) related to or involving any technology defined as fuel cell was included in the budgets for fuel cell R\&D.

Fuel cells are emerging power generation technologies for the efficient, economical, and environmentally acceptable production of electric power for utility and automotive applications. They produce electricity through the electrochemical oxidization of a fuel. Fuel cells have inherent advantages over standard energy conversion devices in that they are not reliant upon the combustion of a fossil fuel. For example, the fuel cell is not efficiency limited by the carnot cycle; therefore, most of the chemical energy of the fuel can be directly converted to electricity and, in some applications, heat. In addition, fuel cells do not produce combustion byproduct gases, which are environmentally restricted. 
Fuel cells consist of two electrodes (anode and cathode) and an electrolyte. They are typically classified by their electrolyte. The primary types of fuel cells are alkaline (AFC) phosphoric acid (PAFC), molten carbonate (MCFC), solid oxide (SOFC), and polymer (PEFC). Figure 1.1 shows the schematics of four of these types. All R\&D concerned with the different types of fuel cells was considered in the overall funding levels. Table 1.1 indicates the distinguishing features of the major fuel cell types.

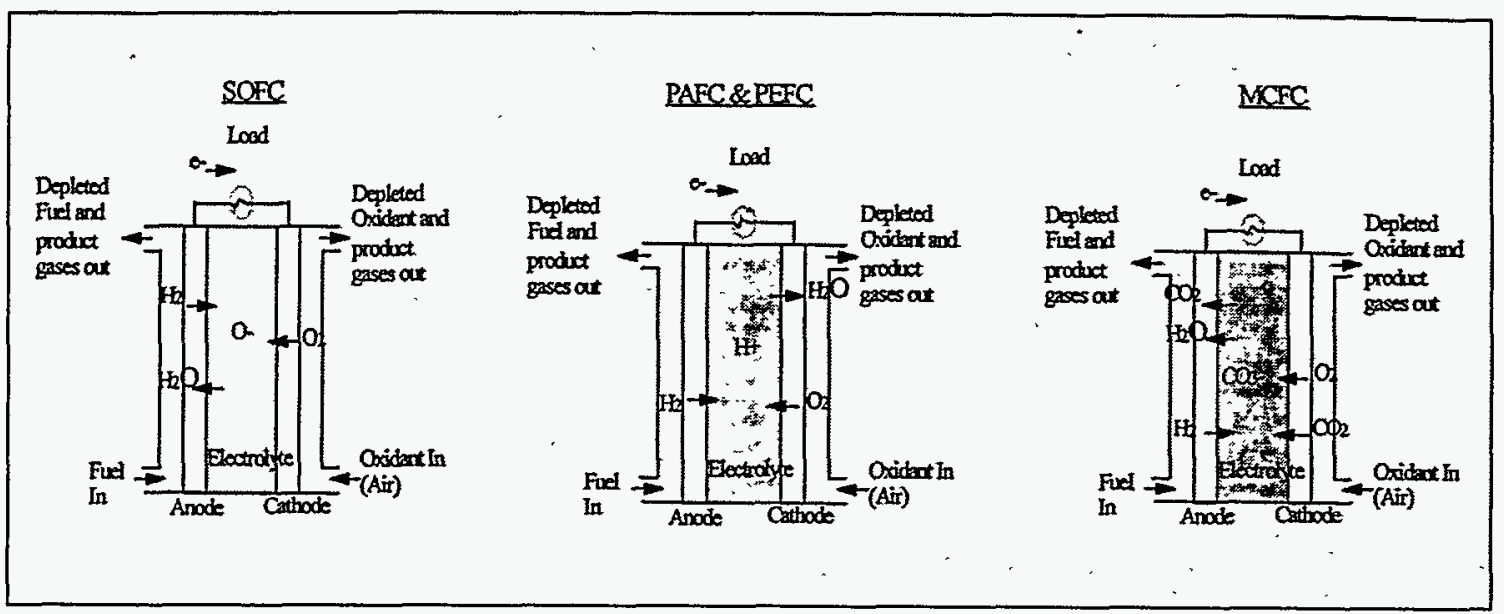

Figure 1.1. Fuel Cell Schematics

Table 1.1. Major Fuel Cell Types and Significant Differences

\begin{tabular}{|l|l|l|l|l|l|}
\hline Type & Electrolyte & $\begin{array}{c}\text { Operating } \\
\text { Temp }\left({ }^{\circ} \mathrm{C}\right)\end{array}$ & Fuel & Poison Gases & \multicolumn{1}{|c|}{$\begin{array}{c}\text { Electro- } \\
\text { catalyst }\end{array}$} \\
\hline Alkaline & $\begin{array}{l}85 \% \mathrm{KOH} \\
35-50 \% \mathrm{KOH} \\
\text { Electrolyte } \\
\text { retained in } \\
\text { asbestos } \\
\text { matrix }\end{array}$ & $\begin{array}{l}250 \\
<120\end{array}$ & & $\begin{array}{l}\mathrm{Ni}, \mathrm{Ag} \text {, metal } \\
\text { oxides, spinels } \\
\text { and noble } \\
\text { metals (anode } \\
\text { and cathode) }\end{array}$ \\
\hline $\begin{array}{l}\text { Phosphoric } \\
\text { Acid }\end{array}$ & $\begin{array}{l}\text { Concentrated } \\
\text { phosphoric } \\
\text { acid retained } \\
\text { in silicon } \\
\text { carbide matrix }\end{array}$ & $150-220$ & $\mathrm{H}_{2}$ & $\begin{array}{l}\mathrm{CO}(>0.5 \%) \\
\mathrm{S}\left(\mathrm{H}_{2} \mathrm{~S} \text { and }\right. \\
\mathrm{COS})(>50 \\
\mathrm{ppm})\end{array}$ & $\begin{array}{l}\mathrm{Pt} \text { (anode and } \\
\text { cathode) }\end{array}$ \\
\hline
\end{tabular}


Table 1.1. Continued.

\begin{tabular}{|c|c|c|c|c|c|}
\hline Type & Electrolyte & $\begin{array}{l}\text { Operating } \\
\left.\text { Temp ( }{ }^{\circ} \mathrm{C}\right) \\
\end{array}$ & Fuel & Poison Gases & $\begin{array}{l}\begin{array}{l}\text { Electro- } \\
\text { catalyst }\end{array} \\
\end{array}$ \\
\hline $\begin{array}{l}\text { Molten } \\
\text { Carbonate }\end{array}$ & $\begin{array}{l}\mathrm{Na}, \mathrm{K} \\
\text { carbonates } \\
\text { retained in a } \\
\text { ceramic matrix } \\
\text { of } \mathrm{LiAlO}_{2}\end{array}$ & $600-700$ & $\mathrm{H}_{2}, \mathrm{CO}$ & $\begin{array}{l}\mathrm{S}\left(\mathrm{H}_{2} \mathrm{~S} \text { and }\right. \\
\mathrm{COS})(>0.5 \\
\text { ppm) }\end{array}$ & $\begin{array}{l}\mathrm{Ni} \text { (anode), } \\
\text { Nickel Oxide } \\
\text { (cathode) }\end{array}$ \\
\hline Solid Oxide & $\begin{array}{l}\text { Nonporous } \\
\text { metal oxide, } \\
\text { such as } \\
\mathrm{Y}_{2} \mathrm{O}_{3-} \\
\text { stabilized } \\
\mathrm{ZrO}_{2}\end{array}$ & $650-1000$ & $\mathrm{H}_{2}, \mathrm{CO}, \mathrm{CH}_{4}$ & $\begin{array}{l}\mathrm{S}\left(\mathrm{H}_{2} \mathrm{~S} \text { and }\right. \\
\mathrm{COS})(>1.0 \\
\mathrm{ppm})\end{array}$ & $\begin{array}{l}\mathrm{CoZrO2} \text {, } \\
\text { NiZrO2 } \\
\text { cermet (anode) } \\
\text { Sr-doped } \\
\text { LaMnO3 } \\
\text { (cathode) }\end{array}$ \\
\hline Polymer & $\begin{array}{l}\text { Flourinated } \\
\text { sulfonic acid } \\
\text { ion exchange } \\
\text { membrane }\end{array}$ & $<120$ & $\mathrm{H}_{2}$ & $\begin{array}{l}\mathrm{CO}(>10 \\
\mathrm{ppm})\end{array}$ & $\begin{array}{l}\mathrm{Pt} \text { (anode and } \\
\text { cathode) }\end{array}$ \\
\hline
\end{tabular}

\subsubsection{Advanced Gas Turbines}

Advanced gas turbines are defined as exhibiting the following characteristics: ultra-high efficiency, environmental superiority, cost competitiveness, fuel flexibility, and RAM (USDOE 1993). The definition of advanced gas turbines helped determine whether a $R \& D$ program should be considered in the overall data of advanced gas turbine $R \& D$.

\section{Ultra-high efficiency}

Ultra-high efficiencies are defined by the U.S. advanced turbine system program as follows: utility systems--60\% (lower heating value basis) and industrial systems-- $15 \%$ improvement over today's best gas turbine systems.

To improve efficiency in advanced gas turbines, research centers on cycle modifications and higher firing temperatures. Cycle modifications include use of innovative cycles involving intercooling, chemical recuperation, moisture injection and, reheat combustors. Firing temperatures of up to $2,600 \mathrm{oF}$ are required to meet efficiency gains of advanced gas turbines; therefore, research applied to changing turbine design (i.e., hot wall ceramics, catalytic combustion, or staged combustion) was considered in overall R\&D 
funding levels. Table 1.2 indicates the performance of gas turbines currently available through commercial manufacturers.

Table 1.2. Current Gas Turbine Performance

\begin{tabular}{|c|c|c|}
\hline Gas Turbine Style & $\begin{array}{c}\text { Simple-Cycle } \\
\text { Efficiency (\%) }\end{array}$ & $\begin{array}{c}\text { Combined-Cycle } \\
\text { Efficiency (\%) }\end{array}$ \\
\hline Utility Scale & 35 & 53 \\
\hline Industrial Scale & $29-34$ & approx. 40 \\
\hline Aeroderivative & 40 & approx. 53 \\
\hline
\end{tabular}

\section{Environmental superiority}

A primary goal of the U.S. advanced turbine system program is to reduce emission levels of nitrogen oxides, carbon dioxide, carbon monoxide, and unburned hydrocarbons. Nitrogen oxide emissions from today's gas turbines are typically greater than $9 \mathrm{ppm}$. Carbon monoxide and unburned hydrocarbon emissions are greater than, $20 \mathrm{ppm}$. All research applied toward reducing emission levels to less than the currently available levels (e.g., staged combustion) was considered advanced gas turbine R\&D.

\section{Cost competitiveness}

A fundamental goal of the U.S. advanced turbine system program is to lower the cost of electricity $10 \%$ from today's levels. The two primary methods for reducing cost to produce electricity are (1) power output increases over today's standards and (2) reduction of environmental clean-up equipment. All R\&D concerned with these two areas was considered in overall funding levels.

\section{Fuel flexibility}

Research concerned with the use of coal or biomass fuels derived for the use in advanced gas turbines was considered in the overall R\&D funding levels.

Reliability, Availability, and Maintainability (RAM)

All research towards RAM improvements was considered in overall R\&D funding levels. 


\subsection{Report Organization}

The following sections center on the methodology, expenditures, reports of the selected countries, and conclusions of the analysis; these sections are followed by text references and five appendices. Section 2 details the methodology maintained throughout the task. The procedures followed during the literature review, country selection, and data collection and analysis are outlined and explained. Section 3 presents $R \& D$ expenditures for the selected countries, including total R\&D, energy, fossil fuel, fuel cell and advanced gas turbine. For each selected country, R\&D expenditures as a percentage of GDP, as a percentage of total $R \& D$, average annual percentage change in $R \& D$ funding, and the percentages of funding from public and private sources are given. Section 4 contains detailed country reports. For each selected country, the following are discussed: total, energy, fossil fuel, fuel cell, and advanced gas turbine R\&D expenditures; structure of R\&D funding sources; breakdown of energy R\&D funding; fuel shares for electricity generation; and overviews of fuel-cell and advanced gas turbine R\&D funding. Section 5 presents the conclusions that resulted from the analysis.

Appendix A presents R\&D expenditure data used throughout the analysis. Appendix B contains a list of fuel-cell R\&D projects and estimated expenditures for the selected countries. Appendix $C$ includes a list of advanced gas turbine $R \& D$ projects and estimated expenditues for the selected countries. Appendix D indicates the ERs and PPPs used in the data analysis. Documents for further reading are listed in Appendix E. 


\section{Methodology}

The overall report methodology followed the flow chart of Figure 2.1. A literature review was conducted to establish the initial list of countries heavily involved in energy $\mathrm{R} \& D$ or having programs in fuel cells or advanced gas turbines. Foreign government embassies located in the U.S.; U.S. embassies located abroad; and agencies, associations, and institutions were contacted to collect information on R\&D budgets within the respective countries. To collect more detailed budgetary data, foreign government agencies and private companies involved in fuel cell or advanced gas turbine R\&D were contacted. The R\&D budgetary data was analyzed to identify potential problem areas and information deficiencies. Once data deficiencies and irregularities were identified, further contacts were made with foreign and U.S. embassies, foreign governments, and private companies to resolve budgetary gaps and information inconsistencies.

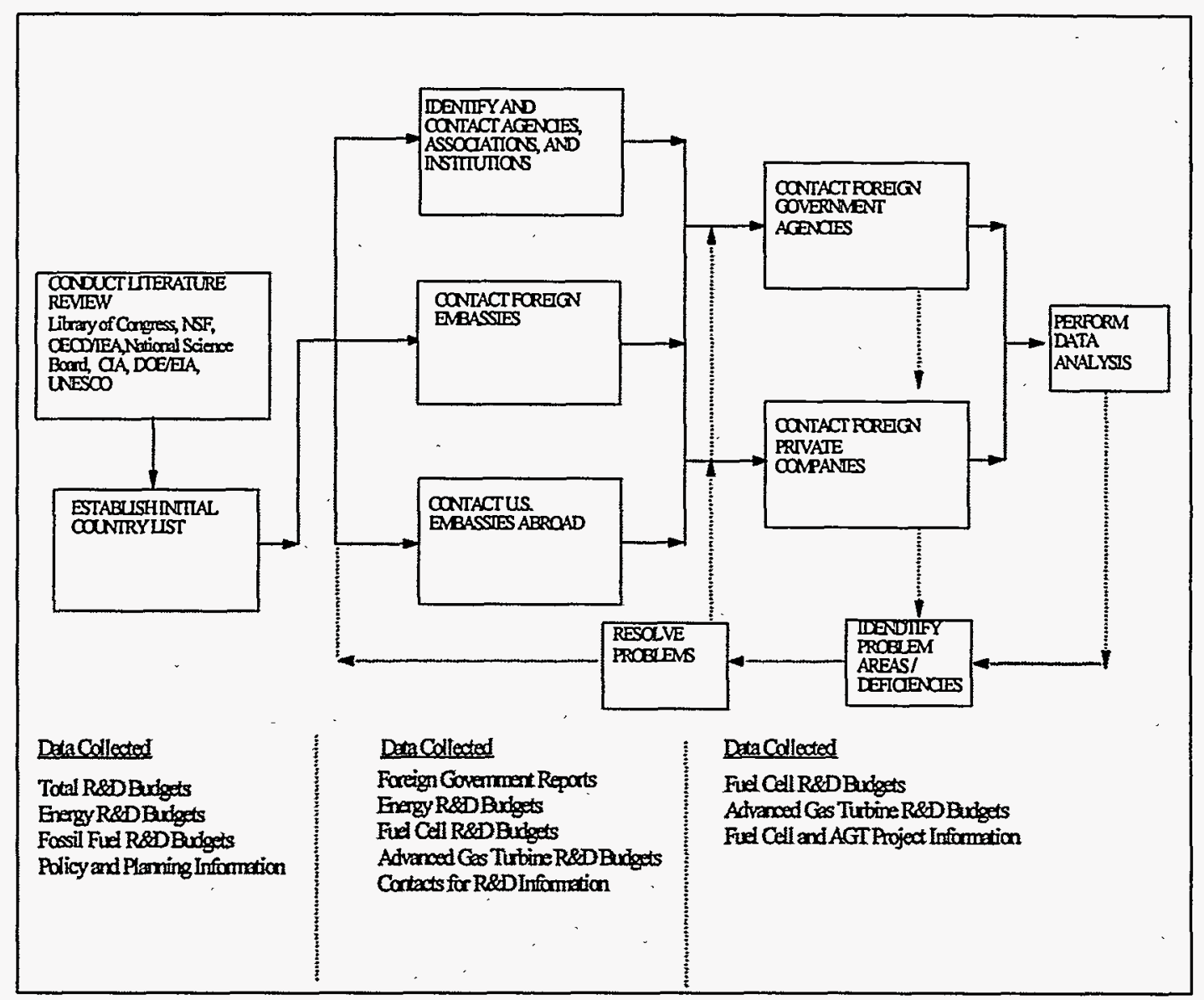

Figure 2.1 Methodology 


\subsection{Literature Review}

The initial literature review was conducted to locate $R \& D$ expenditure data from public and private funding sources available in public documents. The documents reviewed included, but were not limited to, the following:

- Technical and business journals

- OECD/IEA publications

- United Nations publications

- National Science Foundation (NSF) publications

- National Science Board publications

- USDOE documentation

- Central Intelligence Agency (CIA) publications

R\&D materials collected from the initial literature review included total, energy, and fossil fuel budgets; and government planning and policy information on future R\&D. Additional literature reviews were conducted to obtain detailed information on fuel cell and advanced gas turbine R\&D expenditures. Documents analyzed included, but were not limited to, annual reports of various private companies; conference proceedings; agency, associations, and institution publications; and marketing reports and brochures from various private companies.

\subsection{Country Selection}

Based on the initial literature search, 15 countries were selected for investigation throughout the analysis. Countries were selected based on their total, energy, fossil fuel, fuel cell, or advanced gas turbine R\&D expenditures. Each of these countries has allocated a significant amount of money toward one of the previously stated $R \& D$ areas or was believed to have had active $R \& D$ concerning fuel cells or advanced gas turbines. Because the EU also provides significant funding for various R\&D activities, it was considered in the report. The countries selected are highlighted in Figure 2.2. 


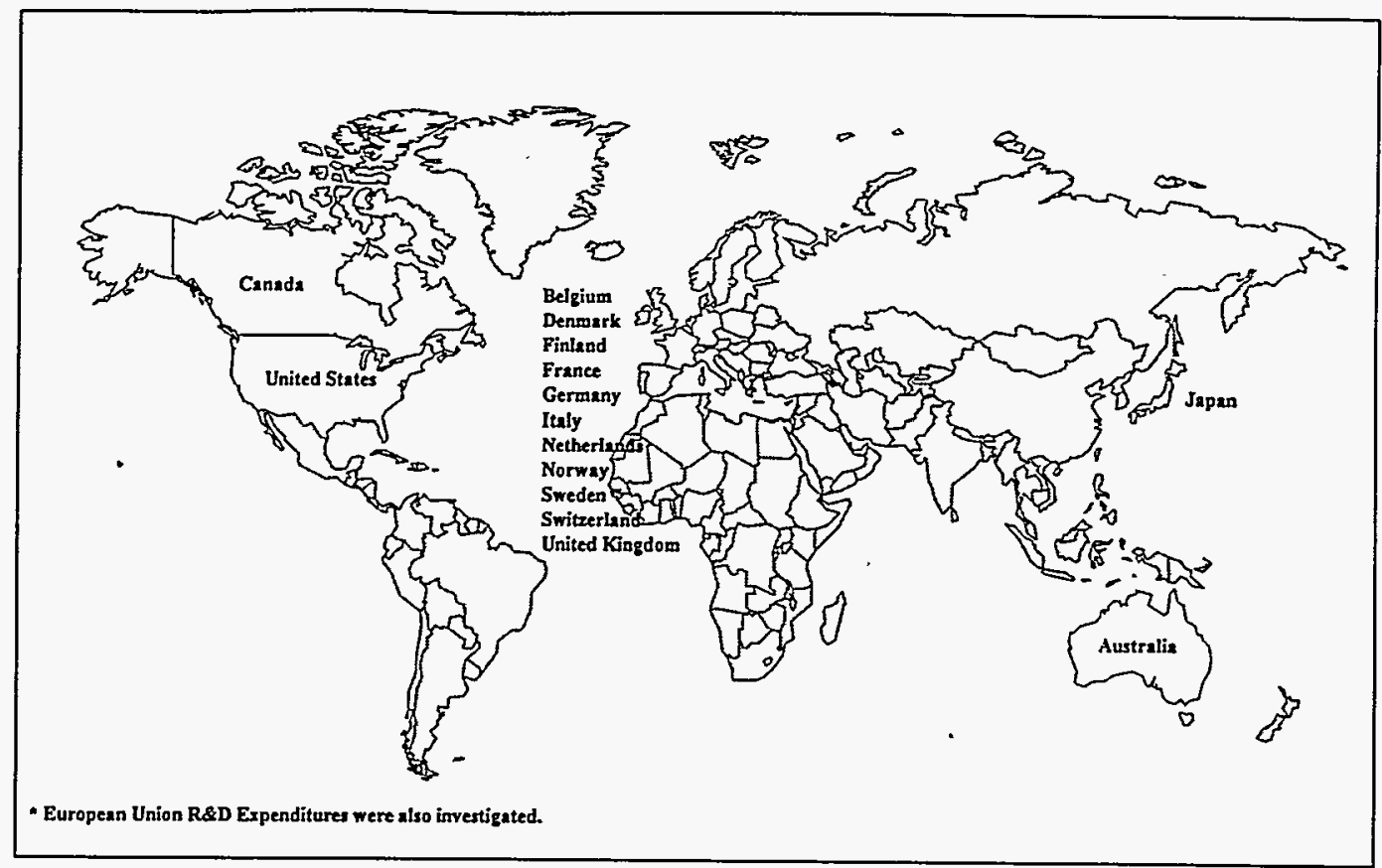

Figure 2.2 Countries Selected*

\subsection{Detailed Data Collection}

Detailed R\&D data was collected through contact of U.S. embassies abroad; foreign government embassies located in Washington D.C.; foreign governments; private companies; and agencies, associations, and institutions identified throughout the literature review. The agencies, associations, and institutions contacted included, but were not limited to, the following:

- Gas Research Institute (GRI)

- Electric Power Research Institute (EPRI)

- American Gas Association (AGA)

- World Energy Council

- Groupe Europeen de Richerche Gaziere (GERG)

- South Carolina Energy Research and Development Center

- Institute of Gas Technology (IGT)

- International Gas Turbine Manufacturers Association (IGTMA)

- Fuel Cell Commercialization Group (FCCG)

The agencies, associations, and institutions contacted provided foreign government energy and R\&D reports, as well as energy and fossil fuel R\&D expenditure data. Little fuel cell and advanced gas turbine R\&D expenditure data was provided by these sources. 
Foreign government embassies located in Washington, D.C. and U.S. embassies abroad provided additional information on fuel cell and advanced gas turbine projects and R\&D funding levels. In addition, personal contacts within foreign governments, overseas private companies, and foreign organizations were made from each of these sources.

Foreign government agencies and private corporations were contacted to fill in any budgetary gaps, to gain insight into the types of fuel cell and advanced gas turbine R\&D currently being pursued, and to collect information pertaining to the relative amount of funding available for gas turbines and fuel cells from private sources. Foreign governments provided $R \& D$ reports, identified the major private corporations involved with advanced gas turbine or fuel cell $R \& D$ within their countries, verified major fuel cell or advanced gas turbine projects in their countries, and, in some cases, provided current levels of public and private funding for fuel cell or advanced gas turbine R\&D. Private companies generally consider R\&D funding information proprietary and are unwilling to divulge levels of funding for areas as specific as fuel cells or advanced gas turbines. For them, funding levels for fuel cells and advanced gas turbines were estimated, based on information published in annual company reports.

\subsection{Data Analysis}

Figure 2.3 indicates the procedure used to analyze the $R \& D$ funding data. $R \& D$ funding levels were collected and a spreadsheet database was created for the analysis of budget data. R\&D funding information was converted to U.S. dollars using both PPP and ERs.

Country R\&D expenditures in U.S. dollars, R\&D expenditures as a percentage of GDP, $R \& D$ expenditures as a percentage of total $R \& D$, and public and private percentages of total funding were compared.

\subsubsection{Public Expenditures}

1994 public R\&D expenditures for total energy, and fossil fuel were estimated based on the average annual percentage change in the respective $R \& D$ category over the most recent four years that data was available. For example, the energy R\&D expenditures for the U.S. decreased from US $\$ 2.696$ billion in 1990 to 2.361 in 1993, an average annual percentage decrease of $4.32 \%$. The 1994 U.S. estimated expenditure for energy R\&D was calculated at US $\$ 2.260$ billion, a decrease of $4.32 \%$ from 1993 . 1994 was chosen as the baseline year to facilitate the analysis of R\&D expenditures on the focal technologies of fuel cells and advanced gas turbines. Public support levels for fuel cell and advanced gas turbine R\&D were generally available for 1994 and estimations based on average 
annual percentage change were not required. In the energy, fossil fuel, fuel cell, and advanced gas turbine subgroups, R\&D expenditures as a percentage of GDP were multiplied by 1,000 . This is indicated throughout the text by (GDP * 1,000).

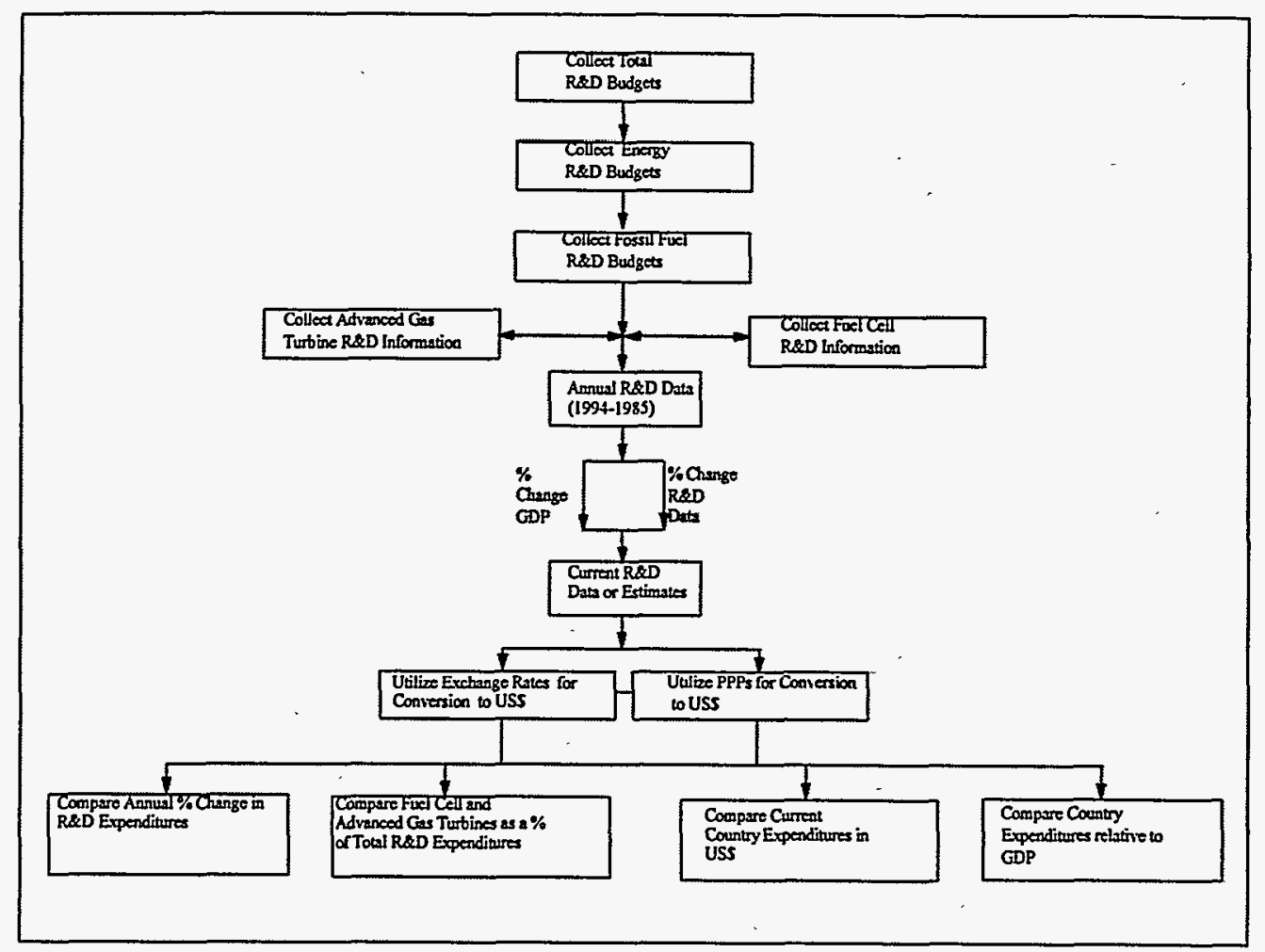

Figure 2.3 Data Analysis Flow Chart

\subsubsection{Private Expenditures}

Funding level information for private companies involved with energy $R \& D$, notably fuel cells and advanced gas turbines, was not as prevalent as public expenditures. 1994 total private expenditures for $R \& D$ was estimated based on the average annual percentage change in the respective $R \& D$ category over the most recent four years that data was available. Private support for energy and fossil fuel R\&D was estimated based on known levels of public support and the ratio of public to private funding for total R\&D.

The procedure utilized for calculation of private fuel cell and advanced gas turbine $R \& D$ is outlined in the flow chart of Figure 2.4. Private companies considered information on R\&D funding levels for fuel cells and advanced gas turbines proprietary information. In these cases private funding levels were estimated based on information in companies annual reports, which typically provide total sales, total R\&D funding, and total sales 
within the product line responsible for gas turbines or fuel cells. The total R\&D funding as a percentage of total sales was calculated and used as a basis for calculating product line and eventually fuel cell and advanced gas turbine R\&D. In scenarios where total R\&D funding was unavailable, an average R\&D percentage of sales (5\%) was used. Five percent was the average $R \& D$ percentage of sales for the companies reporting $R \& D$ and sales figures. Product line sales were multiplied by the ratio of total $R \& D$ to total sales to estimate product line $\mathrm{R} \& \mathrm{D}$ funding. Advanced gas turbine and fuel cell sales were also multiplied by the ratio of total $R \& D$ to total sales to estimate the level of $R \& D$ funding possible for fuel cell and advanced gas turbine activities. In cases where advanced gas turbine and, for a select group of mainly Japanese companies, fuel cell sales were unavailable, estimates were made to the percentage of total product line sales for which fuel cells or advanced gas turbines were responsible. In cases where the overall size and scope of a fuel cell project was known, total funding levels were estimated based on known funding levels of projects similar in size and scope.

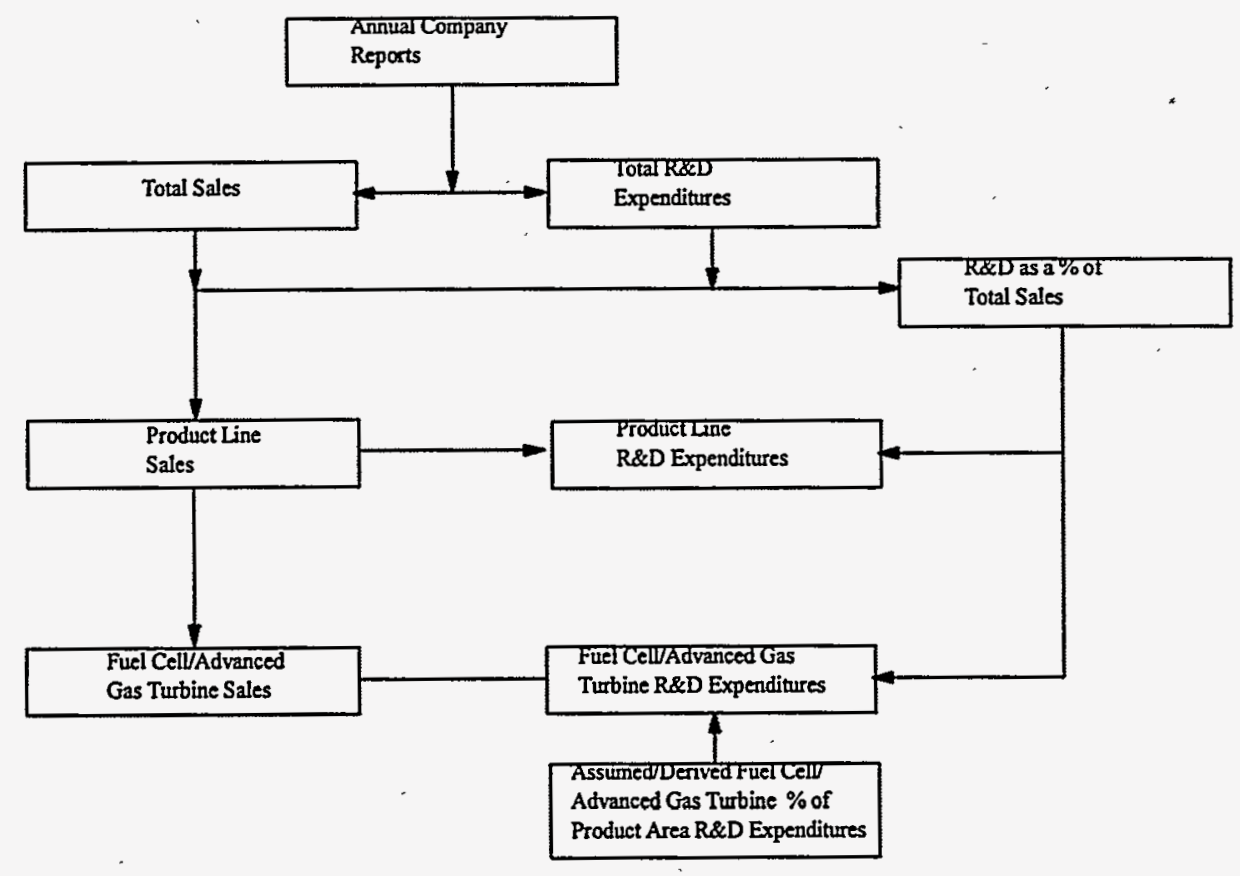

Figure 2.4 Estimation of Privately-Funded R\&D Expenditures 


\section{R\&D Expenditures of the Selected Countries}

R\&D expenditures in various areas were compared and contrasted for 15 industrialized countries. R\&D expenditures were compiled in the areas of total energy, fossil fuel, fuel cells, and advanced gas turbines. For each area, the following items were compared on a country-by-country basis:

- Total level of expenditures

- Expenditures as a percentage of GDP

- Percentage change in funding levels over past the 5-to-10 years

- Sector expenditures as a percentage of total R\&D expenditures

- Percentage of funding provided by public and private sources

Each country's expenditures, funding sources, fuel cell projects, and advanced gas turbine projects are described in Section 4.

\subsection{World R\&D Expenditures}

This section examines total $R \& D$ expenditures, $R \& D$ expenditures as a percentage of GDP, average annual percentage change in $R \& D$ funding, and percentage of total expenditures funded by public and private sources.

\subsubsection{Total Expenditures}

Approximately US $\$ 450$ billion was allocated to R\&D throughout the world in 1994. Figure 3.1 indicates R\&D allocations from public and private sources converted to US\$ by ERs and PPPs. Utilizing ERs for currency conversion, the U.S and Japan are clearly the world's R\&D funding leaders. The U.S. allocated approximately US $\$ 170$ billion during 1994, while Japan budgeted US\$163.5 billion. Combined, the U.S. and Japan accounted for approximately $69 \%$ of all R\&D funded in 1994. Germany, France, United Kingdom, and Italy provided the majority of the additional $R \& D$ funding during that same year. These six countries accounted for close to $94 \%$ of the total R\&D funding throughout the 15 selected countries in 1994 (See Table 3.1). 
Due to the relatively high cost of living in Japan, the PPP is considerably more Japanese yen to the U.S. dollar than the ER $(E R=99.75$ yen/U.S.\$; PPP = 187 yen/U.S.\$).

Utilizing PPPs, the Japanese allocation for 1994 reduces to approximately US $\$ 80$ billion or $22 \%$ of the total R\&D funding throughout the world. The U.S. contribution increases to approximately $43 \%$ of the total R\&D funding throughout the world. Germany, France, United Kingdom, and Italy remained the major providers of additional R\&D funding when using PPPs. These six countries accounted for approximately $91 \%$ of the 15 selected countries total 1994 R\&D funding.

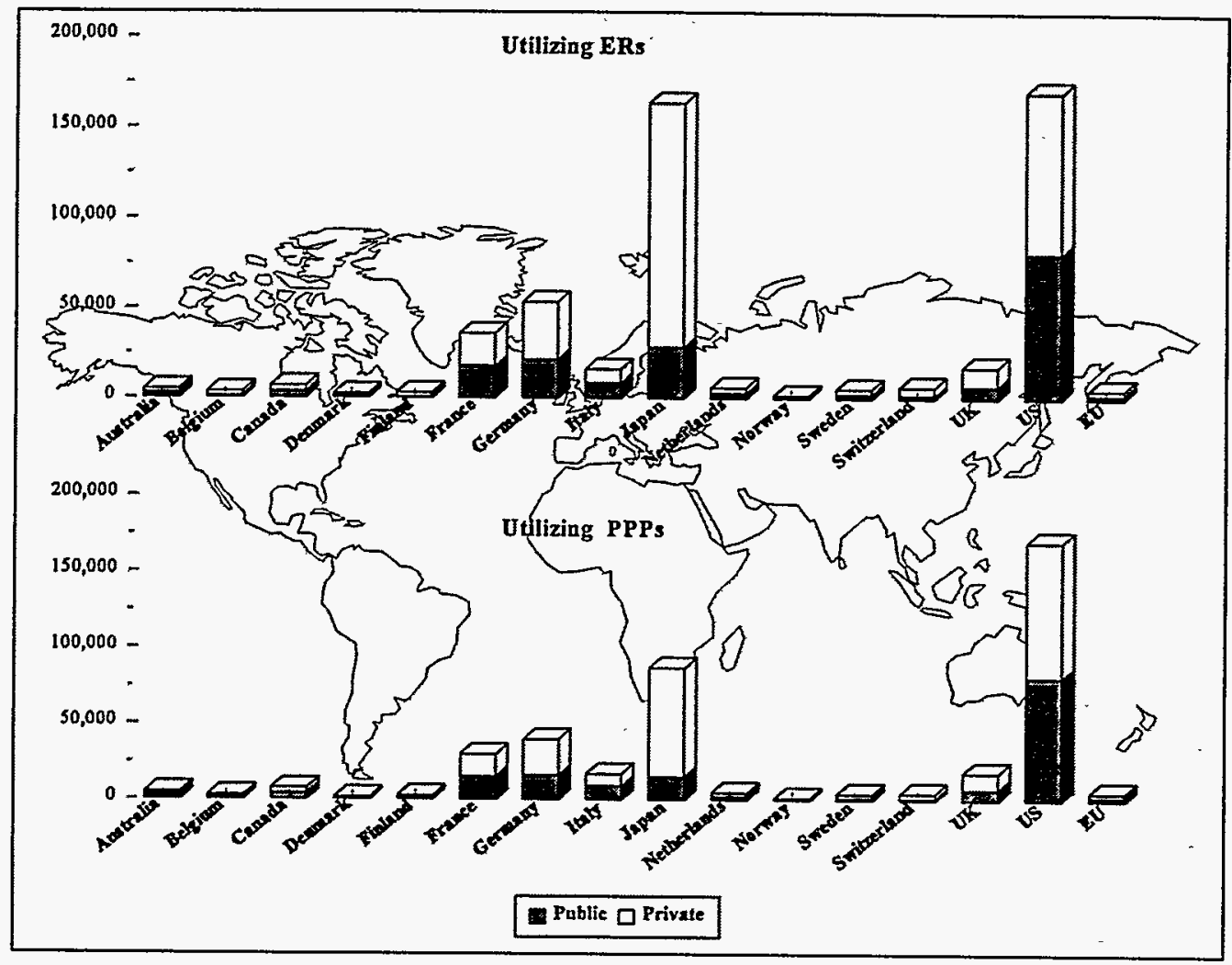

Figure 3.1. 1994 Worldwide R\&D Expenditures (US\$ million)

On average, the private sector funded, $58 \%$ of the total R\&D funding throughout the selected countries. Japan, Finland, Belgium, Switzerland, United Kingdom, Denmark, and Germany all have a private-sector level of support for total R\&D expenditures that are above the average. Private-sector contributions in Japan account for almost $83 \%$ of the total R\&D expenditures, while only $52 \%$ of the total R\&D expenditures were supplied by the private sector in the U.S.. At the other end of the spectrum, close to $60 \%$ of the total R\&D in Norway is funded by the government, and Australia, Canada, and Italy have government commitments greater than $50 \%$. Information was unavailable on private contributions to energy and fossil fuel $R \& D$; therefore, the total $R \& D$ percentages 
were used to estimate energy and fossil fuel R\&D funding by the private and public sectors in each country for the analysis presented in Sections 3.2.1 and 3.3.1.

Table 3.1. Estimated 1994 R\&D Expenditures for Selected Countries (US\$million)

\begin{tabular}{|l|l|l|l|l|l|l|}
\hline Country & GDP & Total & Energy & $\begin{array}{l}\text { Fossil } \\
\text { Fuels }\end{array}$ & $\begin{array}{l}\text { Fuel } \\
\text { Cells }\end{array}$ & $\begin{array}{l}\text { Advanced } \\
\text { Gas } \\
\text { Turbines }\end{array}$ \\
\hline Australia & 280,900 & $4,984.4$ & 167.7 & 41.6 & 1.0 & 0.0 \\
\hline Belgium & 211,300 & $3,562.1$ & 117.9 & 117.9 & 2.25 & 0.0 \\
\hline Canada & 537,400 & $6,869.5$ & 945.2 & 285.3 & 32.1 & 0.1 \\
\hline Denmark & 137,700 & $2,634.1$ & 139.2 & 25.3 & 8.5 & 0.0 \\
\hline $\begin{array}{l}\text { European } \\
\text { Union }\end{array}$ & 248,800 & $5,224.0$ & 491.0 & 39.3 & 11.1 & 0.0 \\
\hline Finland & 70,000 & $3,188.3$ & 206.0 & 24.9 & 0.5 & 0.0 \\
\hline France & $1,269,800$ & $3,6175.3$ & $1,137.5$ & 76.7 & 12.0 & 22.9 \\
\hline Germany & $1,790,000$ & $53,470.2$ & $1,005.4$ & 73.4 & 53.1 & 68.3 \\
\hline Italy & 959,100 & $16,332.9$ & 636.8 & 184.7 & 29.7 & 0.1 \\
\hline Japan & $4,757,800$ & $16,3506.9$ & $30,493.7$ & $2,369.0$ & 203.8 & 129.0 \\
\hline Netherlands & 317,600 & $6,151.2$ & 310.6 & 24.8 & 16.2 & 5.0 \\
\hline Norway & 102,400 & $1,967.3$ & 93.6 & 22.5 & 3.9 & 0.0 \\
\hline Sweden & 173,600 & $5,477.0$ & 172.1 & 1.0 & 3.0 & 116.0 \\
\hline Switzerland & 237,000 & $6,622.6$ & 547.0 & 47.8 & 3.0 & 116.0 \\
\hline Knited & 927,000 & $17,810.0$ & 408.1 & 40.8 & 12.0 & 509.5 \\
\hline United States & $6,579,500$ & $169,809.2$ & $4,751.2$ & 700.3 & 150.5 & 520.5 \\
\hline
\end{tabular}




\subsubsection{Expenditures As a Percentage of GDP}

Figure 3.2 indicates the R\&D funding levels as a percentage of GDP. Analyzing $R \& D$ as a percentage of GDP provides a method for normalizing the level of expenditures and was interpreted as a measure of the R\&D intensity of each country. Finland is shown to be the most R\&D intensive of the selected countries. Approximately $4.6 \%$ of the country's annual GDP is spent on R\&D. Japan, Sweden, Germany, France, Switzerland, and the U.S. have an above-average R\&D percentage of GDP (2.43\%). Canada and Belgium have the lowest level of R\&D spending as a percentage of GDP.

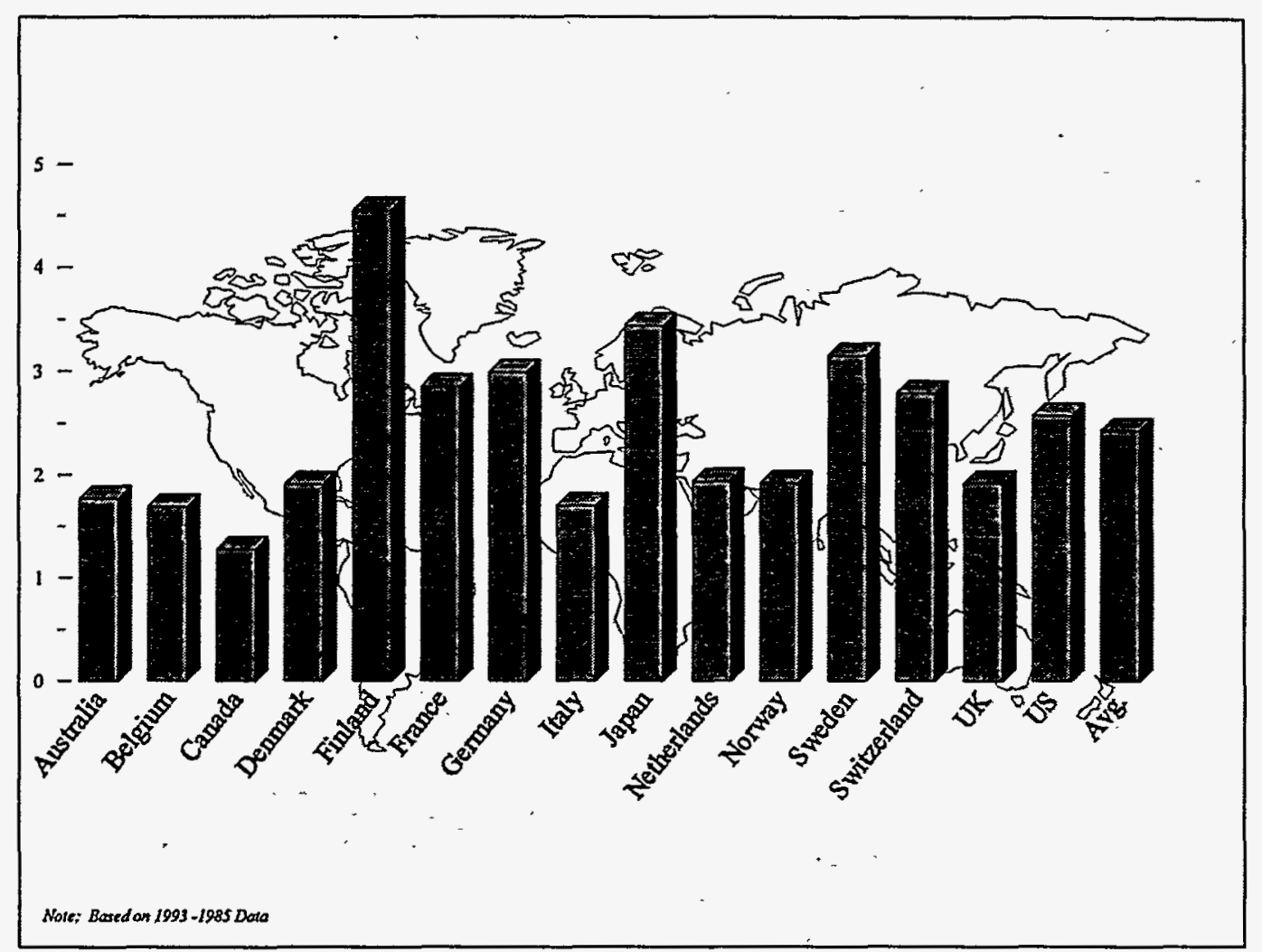

Figure 3.2. 1994 R\&D As a \% of GDP

\subsubsection{Average Annual Percentage Change in R\&D Funding}

The annual percentage change in R\&D funding is represented in Figure 3.3. Overall $R \& D$ funding has increased over the past several years. Total $R \& D$ funding changed at an average annual rate for the selected countries of $7 \%$. Finland has increased R\&D 
funding the most rapidly among the selected countries. Finland R\&D funding levels increased at an annual rate of 14.1\% from 1987 through 1989 (14.1\% assumed for 89-94). 1994 public R\&D expenditures for total, energy, and fossil fuel were estimated based on the average annual percentage change in the respective $R \& D$ category over the most recent years that data was available. Australia, Denmark, France, Italy, and Japan have all increased R\&D funding at annual percentage rate higher than the average (7.1\%). The Netherlands and the U.S.A. have increased R\&D funding levels at the lowest annual rate of the selected countries.

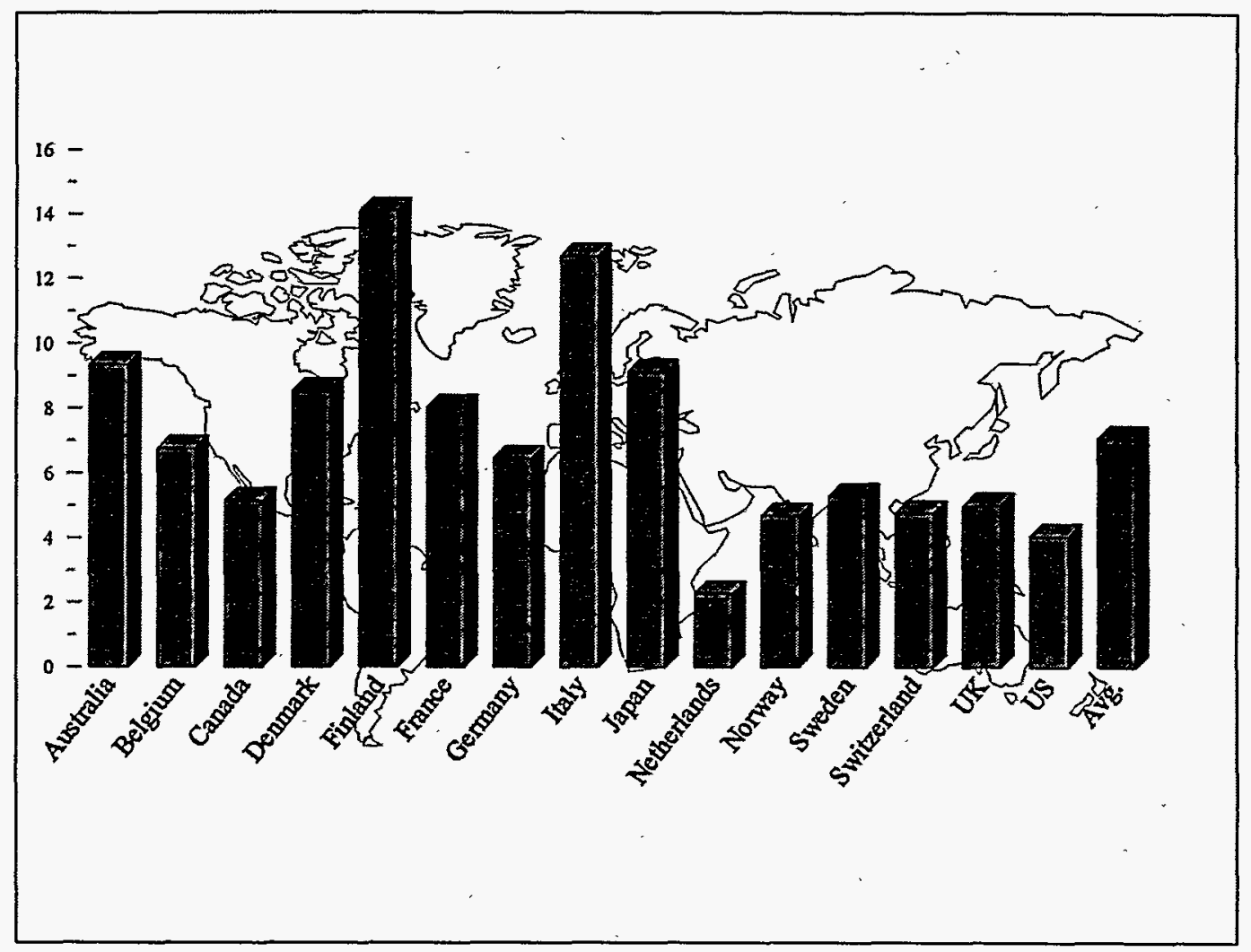

Figure 3.3. Average annual percentage change in R\&D Expenditures (1987-1994)

\subsection{Energy}

Total energy R\&D expenditures, energy R\&D expenditures as a percentage of GDP, average annual percentage change in energy $R \& D$ funding, and energy $R \& D$ expenditures as a percentage of total R\&D expenditures are examined in this section. $\mathrm{R} \& D$ as a percentage of GDP is multiplied by 1,000 (GDP $* 1,000)$. 


\subsubsection{Total Expenditures}

Figure 3.4 indicates the 1994 energy R\&D expenditures of the selected countries. Japan is the world's leader in energy R\&D funding, accounting for approximately $73 \%$ of the total energy R\&D funding that year. The U.S. accounted for $11.4 \%$ of the total energy R\&D funding in 1994, and no other country had a share of greater than $3 \%$. Although the Japanese have $R \& D$ programs in a variety of energy-related programs, close to $85 \%$ of the total Japanese energy R\&D budget for 1993 (1994 data was unavailable) was devoted to nuclear R\&D, and $75 \%$ of the nuclear R\&D budget was devoted specifically to nuclear fusion R\&D. Approximately $8 \%$ of the Japanese energy R\&D budget is committed to fossil fuel R\&D. The U.S. spreads its energy R\&D resources primarily between conservation (14.3\%), fossil fuel (18.2\%), and nuclear (19.1\%).

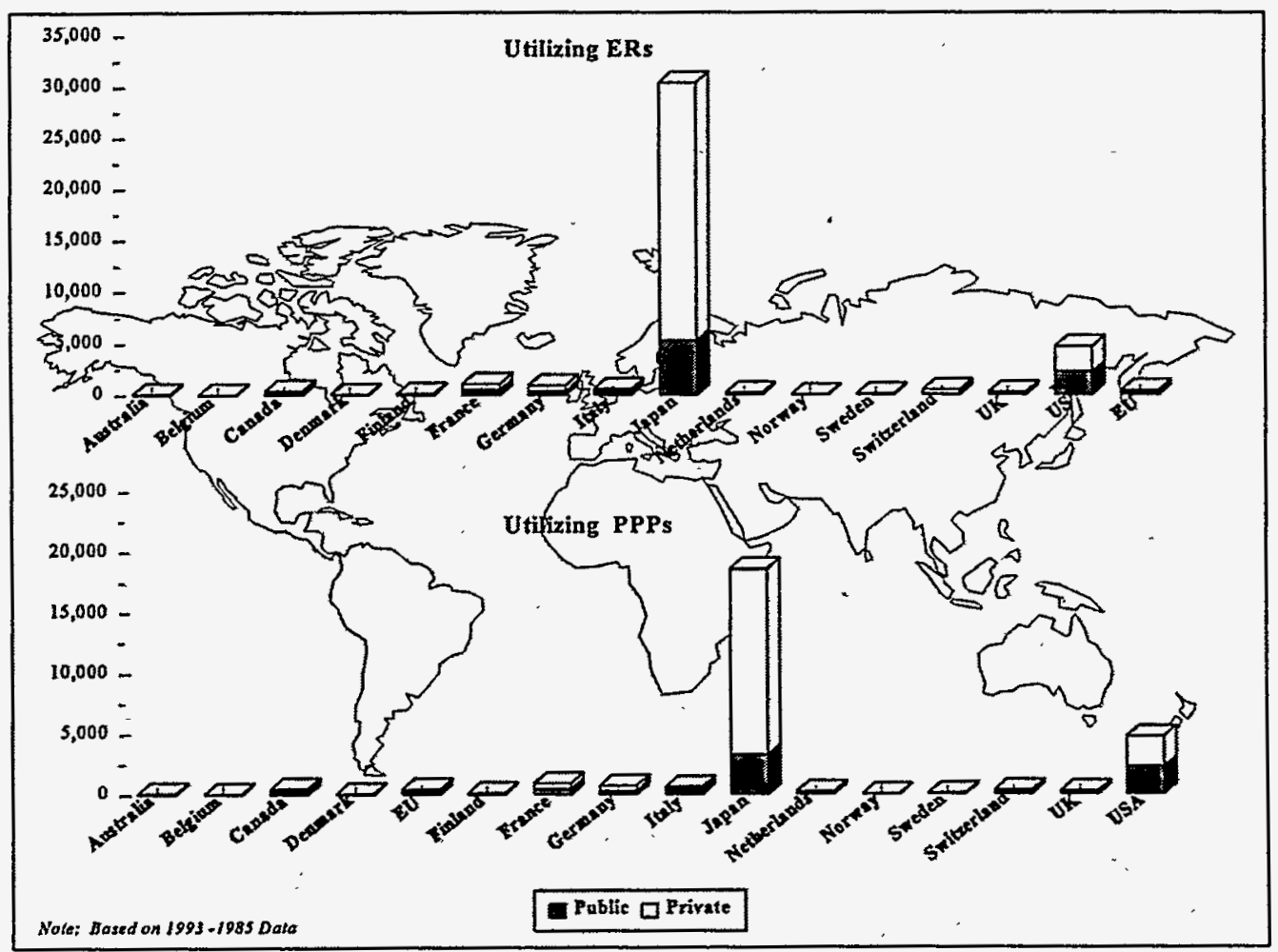

Figure 3.4. 1994 World Energy R\&D Expenditures (US\$ million) 


\subsubsection{Expenditures as a percentage of GDP}

Figure 3.5 displays energy R\&D expenditures as a percentage of GDP for the selected countries. Japan is the most energy R\&D-intensive country in the world, as indicated by its energy R\&D funding ratio to GDP of $641 \%$ (GDP * 1,000). The ratio of energy R\&D to GDP for the Japanese is $250 \%$ greater than for any other selected country. Finland and Switzerland are also energy R\&D-intensive countries, spending $294 \%$ and $230 \%$ of GDP, respectively, on energy R\&D. All other selected countries spent less than $101 \%$ of GDP on energy R\&D. The United States allocated $72 \%$ of GDP for energy R\&D. Germany, Belgium, and the United Kingdom had the lowest ratios $(56,56$, and $44 \%$, respectively).

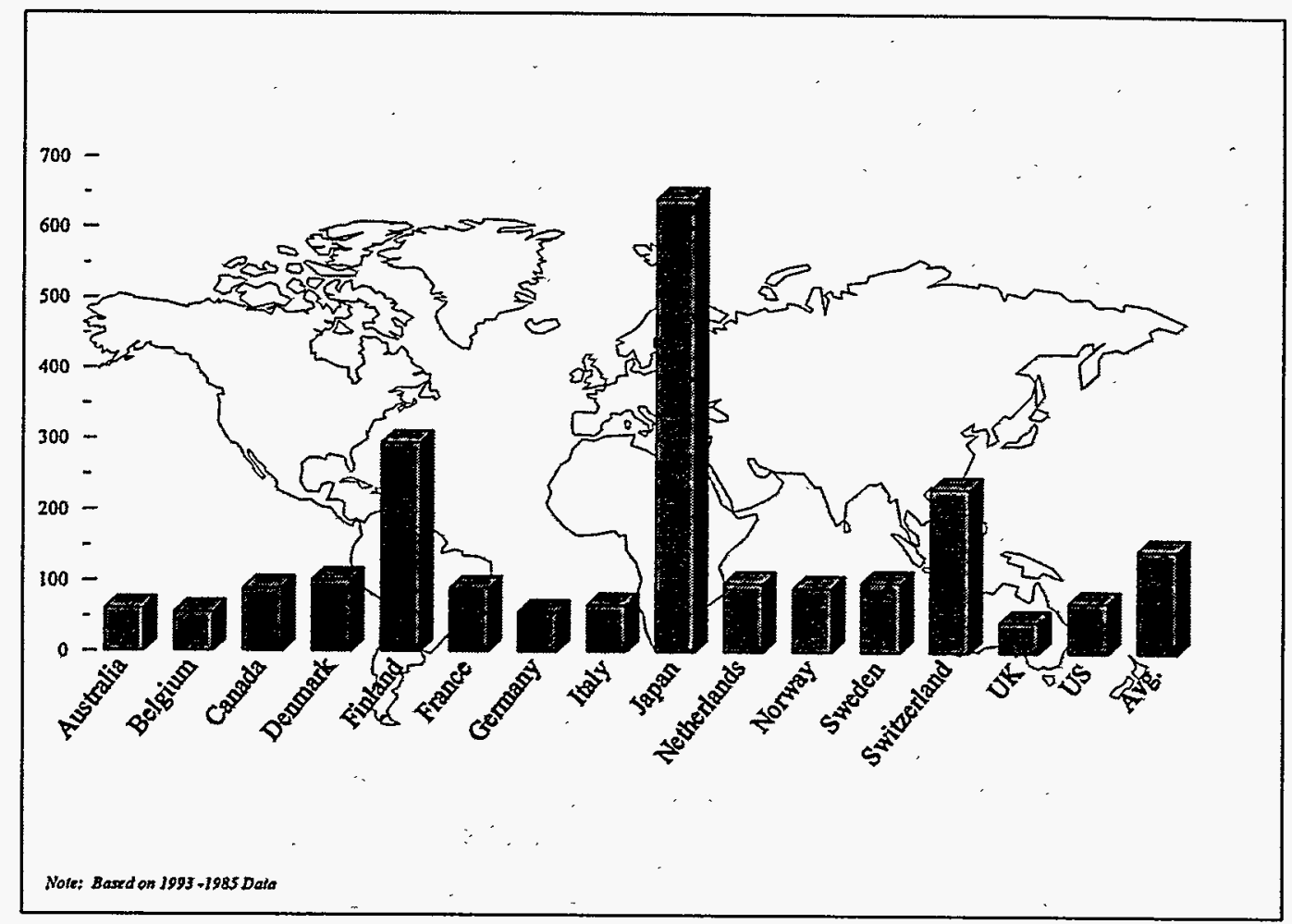

Figure 3.5. 1994 World Energy R\&D As a Percentage of GDP (GDP*1,000)

\subsubsection{Average Annual Percentage Change in R\&D Expenditures}

Figure 3.6 contains the average annual rate of change in energy R\&D funding for the selected countries. The percentage change in energy $R \& D$ funding over the past several 
years varies widely. Overall, the average annual rate of change decreased at a rate of $2 \%$ throughout the selected countries. Australia, Denmark, Finland, Japan, Norway, and Switzerland have increased funding levels more rapidly than their average annual rate of change in GDP over the past several years. The energy R\&D budget in Denmark soared from a 1987 level of approximately US $\$ 22$ million to an estimated level of US $\$ 55$ million, an annual rate of change of $14.14 \%$. In comparison, the GDP of Denmark grew by an average annual rate of $1.6 \%$. Other selected countries did not provide funding for their energy R\&D programs at a level that kept pace with the average annual rate of change in GDP. The United Kingdom, Italy, and Belgium averaged declines of 14.3, 14, and $15.8 \%$, respectively. The U.S., on average, decreased the annual expenditures on energy R\&D by $4.3 \%$.

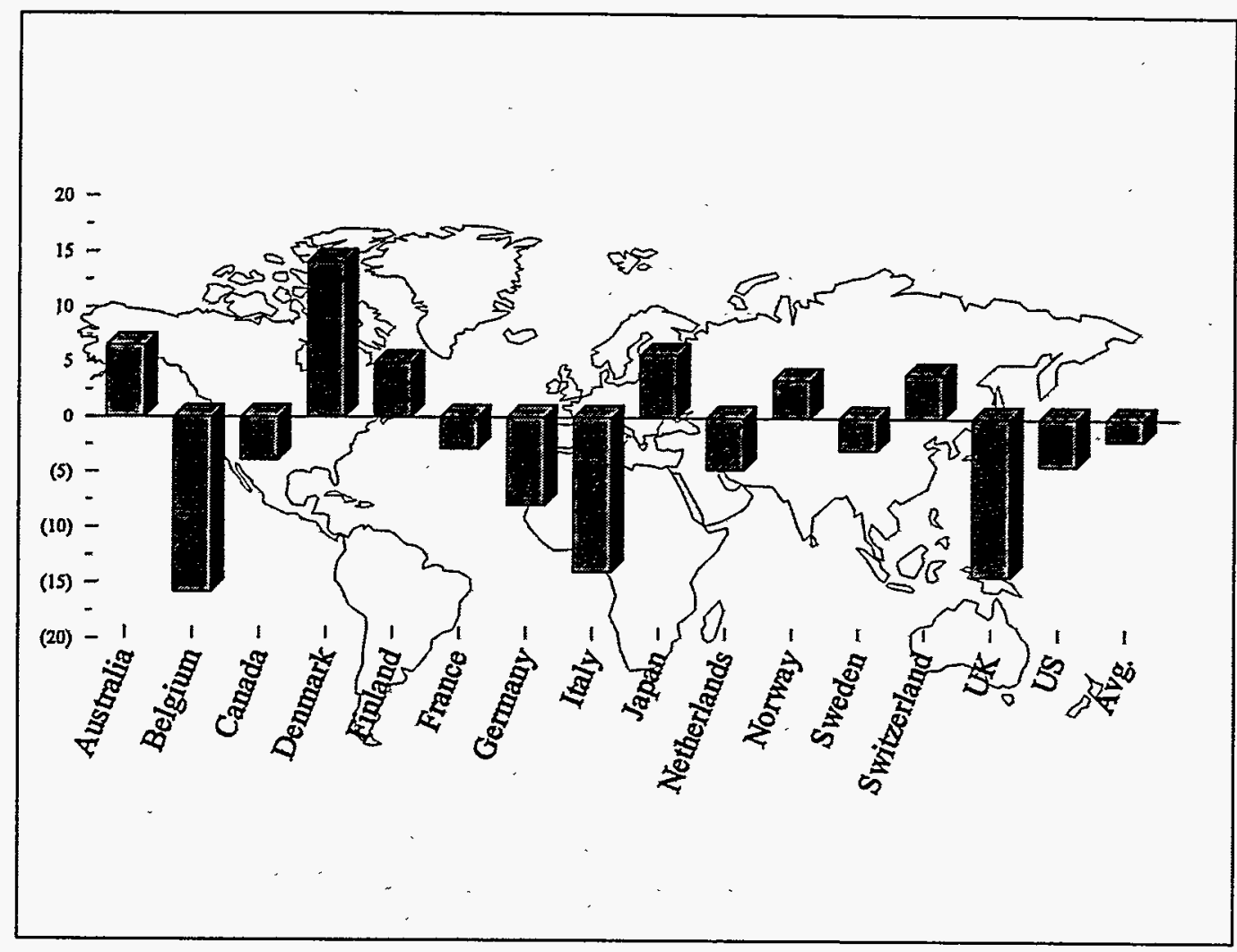

Figure 3.6. Average Annual Rate of Change in Energy R\&D Expenditures (1994-1987)

\subsubsection{Energy Expenditures As a Percentage of Total R\&D Expenditures}

Figure 3.7 shows energy $R \& D$ funding as a percentage of total $R \& D$ for the selected countries. Japan devotes the largest percentage of its R\&D resources to energy. It is the only country to devote more than $10 \%$ of its total R\&D to energy. The average energy percentage of total R\&D was $5.5 \%$. Canada, Finland, and Switzerland are the only other 
countries to commit above average percentages of total R\&D to energy. Germany, United Kingdom, and the United States provide the lowest levels of energy funding as a percentage of total R\&D funding.

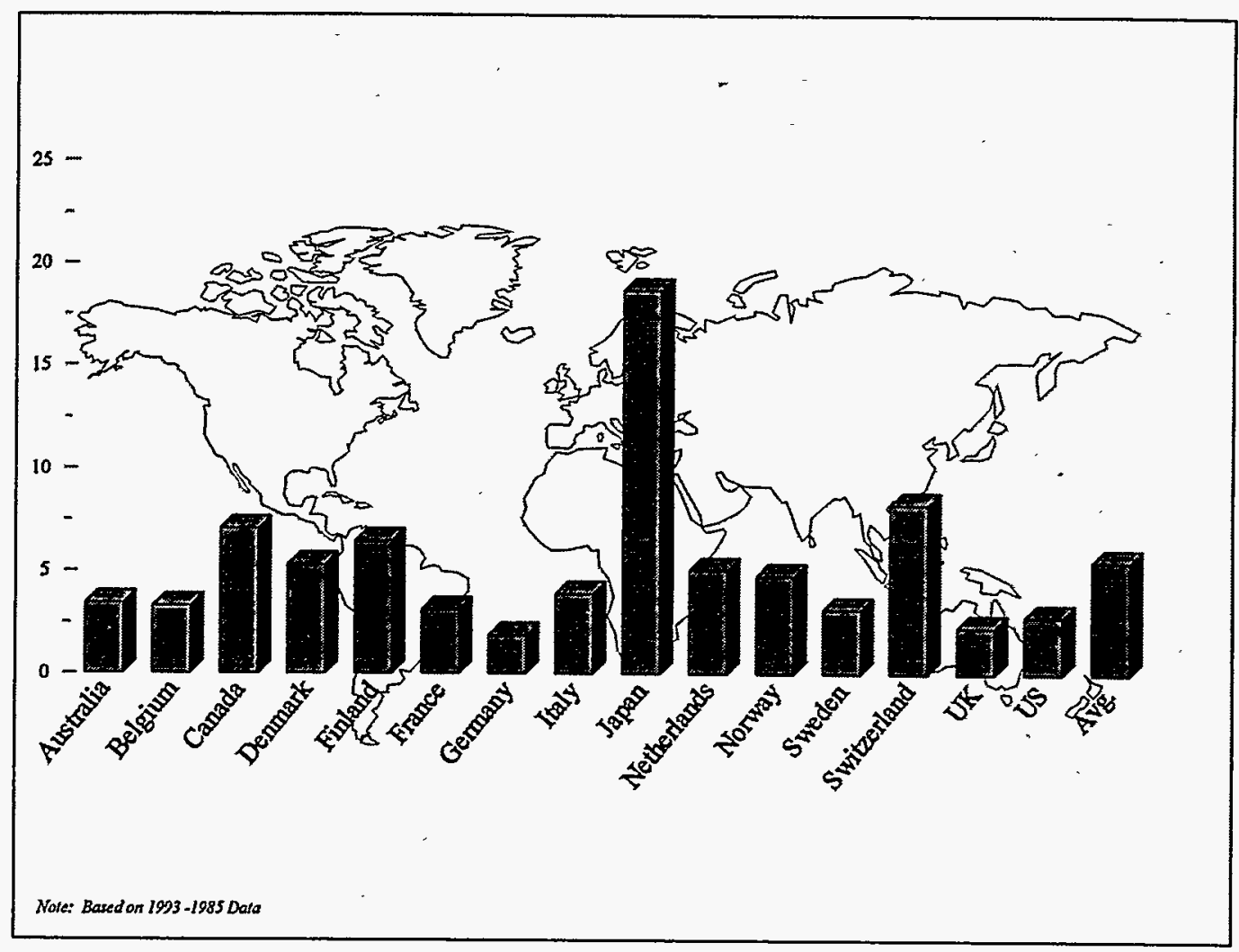

Figure 3.7. 1994 Energy R\&D Funding As a Percentage of Total R\&D Expenditures

\subsection{Fossil Fuel}

This section examines R\&D expenditures for total fossil fuel, fossil fuel expenditures as a percentage of GDP, average annual percentage change in fossil fuel funding, and fossil fuel expenditures as a percentage of total $R \& D$ expenditures. $R \& D$ expenditures as a percentage of GDP is multiplied by 1,000 (GDP * 1,000$)$. 


\subsubsection{Total Expenditures}

Figure 3.8 indicates fossil fuel R\&D expenditures for the selected countries in 1994. Japan and the United States were the world's leaders in fossil fuel research and development expenditures. The Japanese allocated US $\$ 2.4$ billion (ER) and the U.S. allocated US\$700 million for fossil fuel R\&D. The Japanese accounted for $64 \%$ and the U.S. $19 \%$ of the world fossil fuel R\&D expenditures. Utilizing PPPs, the Japanese accounted for $49.7 \%$ and the U.S. $27.5 \%$ of the total fossil fuel R\&D expenditures. Canada, Belgium, France, and Germany all had fossil fuel R\&D expenditures of more than US\$50 million. Australia, Denmark, Finland, Netherlands, Norway, Switzerland, and the United Kingdom allocated between US\$22.5 and 47.8 million for fossil fuel R\&D. The Government of Sweden's reduction in fossil fuel $R \& D$ allocations resulted in a projected 1994 fossil fuel R\&D budget of less than US\$1 million, the lowest of the countries selected. The low level of Swedish R\&D funding indicates that only a handful of small fundamental fossil fuel $R \& D$ projects are being supported by Swedish funding sources. Given the existence of private companies heavily involved with fossil fuel $R \& D$, such as $A B B$, the levels reported for Swedish fossil fuel R\&D funding are likely much lower than actual levels of fossil fuel R\&D funding.

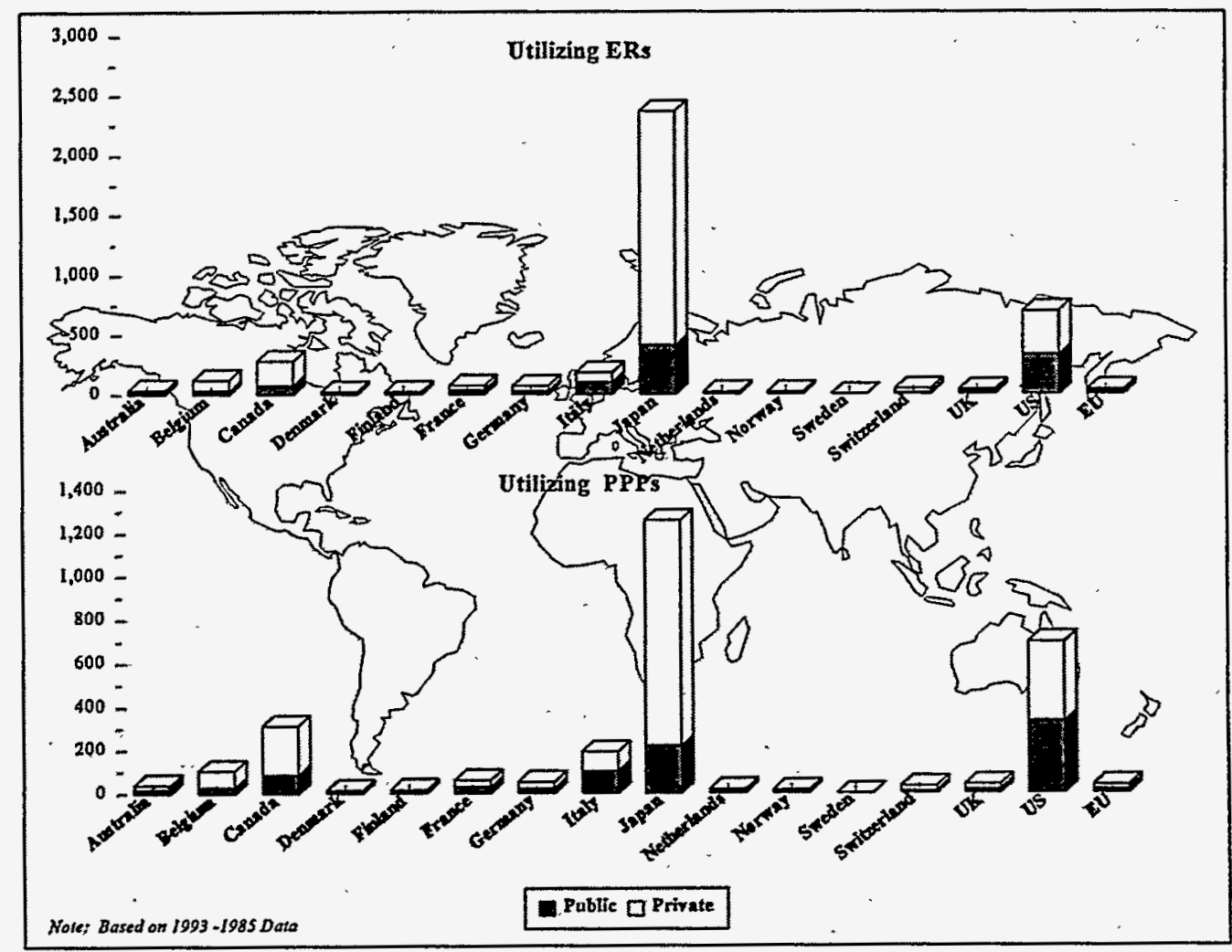

Figure 3.8. 1994 World Fossil Fuel R\&D Expenditures (US\$ millions) 


\subsubsection{Fossil Fuel R\&D Expenditures as a percentage of GDP}

Figure 3.9 presents fossil fuel R\&D expenditures as a percentage of GDP for the selected countries. Belgium (55.8\%) and Japan (49.8\%) provide the highest levels of fossil fuel R\&D expenditures as a percentage of GDP (GDP * 1000). The Government of Belgium increased the level of R\&D funding from US\$2.8 million to US\$24.4 million from 1992 to 1993 . The Japanese have consistently provided high levels of fossil fuel R\&D funding as a percentage of GDP. Finland (35.5\%), Canada (27.3\%), Norway (21.9\%), and Switzerland (20.2\%) all provide levels of fossil fuel R\&D funding as a percentage of GDP greater than the average of the selected countries (18.8\%). The Netherlands, France, United Kingdom, Germany, and Sweden all had levels of fossil fuel R\&D expenditures as a percentage of GDP of less than $10 \%$. The U.S. fossil fuel R\&D expenditures as a percentage of GDP was $10.6 \%$, the ninth highest of the selected countries.

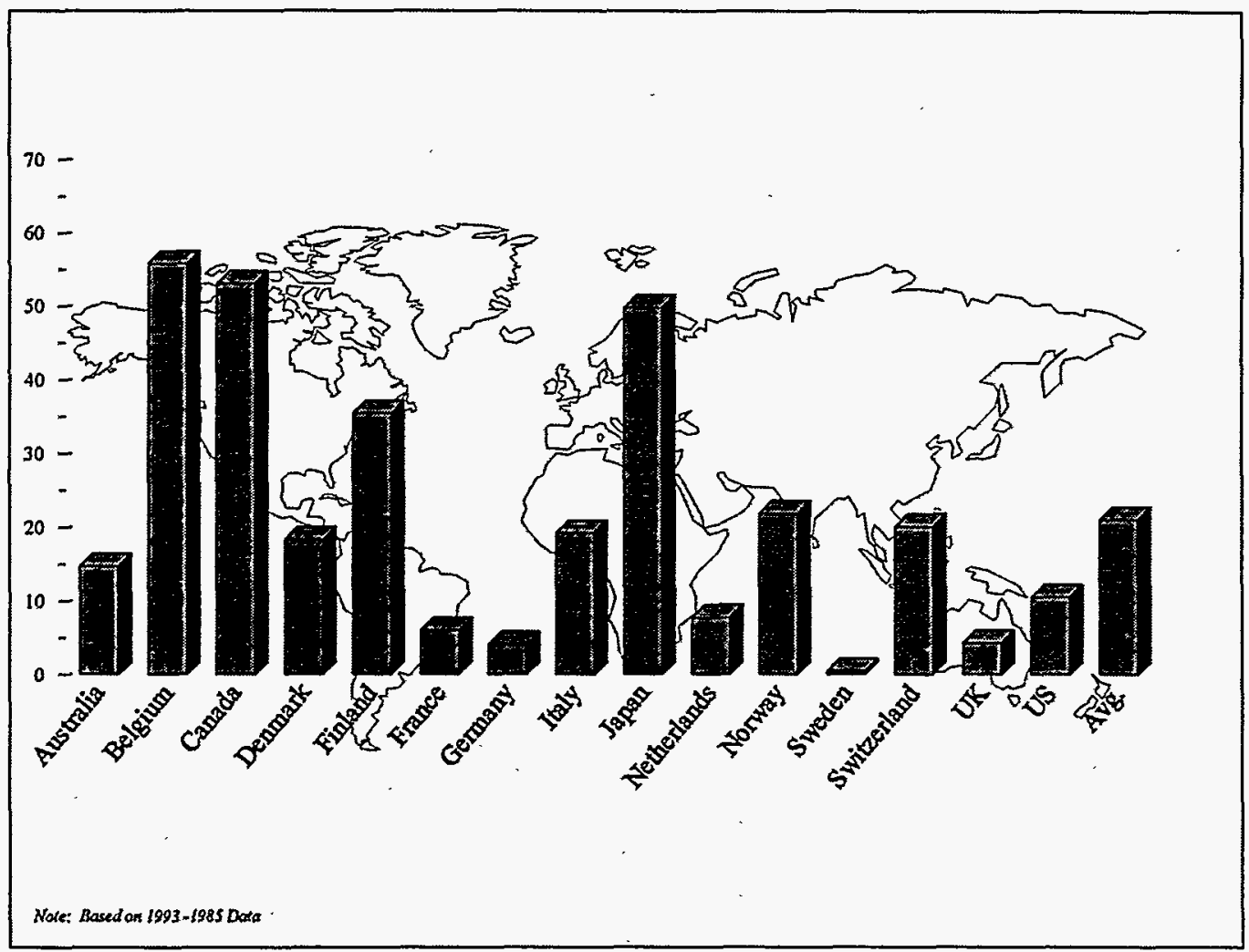

Figure 3.9. 1994 World Fossil Fuel R\&D As a Percentage of GDP $($ GDP *1,000) 


\subsubsection{Average Annual Percentage Change in Fossil Fuel Expenditures}

Figure 3.10 shows the average annual rate of change in fossil fuel R\&D expenditures for the selected countries. Over the past few years, the importance of fossil fuel R\&D changed greatly within the selected countries. Overall, expenditures on fossil fuel R\&D decreased at an average annual rate of $4 \%$ over the past five to seven years. Six countries increased the level of fossil fuel R\&D expenditures over the past several years. Belgium, Denmark, Finland, and Switzerland increased the level of fossil fuel R\&D expenditures at a average rate greater than $10 \%$. Belgium provided an average annual increase in $R \& D$ funding greater than $39 \%$. The Belgium energy R\&D budget decreased over the same period by an average annual value of close to $16 \%$; therefore, close to $100 \%$ of the Belgium energy R\&D budget is now classified as fossil fuel R\&D. Denmark increased funding at an average annual rate of $25 \%$ (from US $\$ 4.1$ million in 1987 to US\$8 million in 1993). Sweden, the United States, and Germany strongly reduced the level of fossil fuel R\&D funding over the past several years. The Government of Sweden reduced its country's fossil fuel R\&D budget from a 1990 value of US\$6.6 million to a 1993 value of US\$0.8 million, a 50.5\% average annual rate reduction.

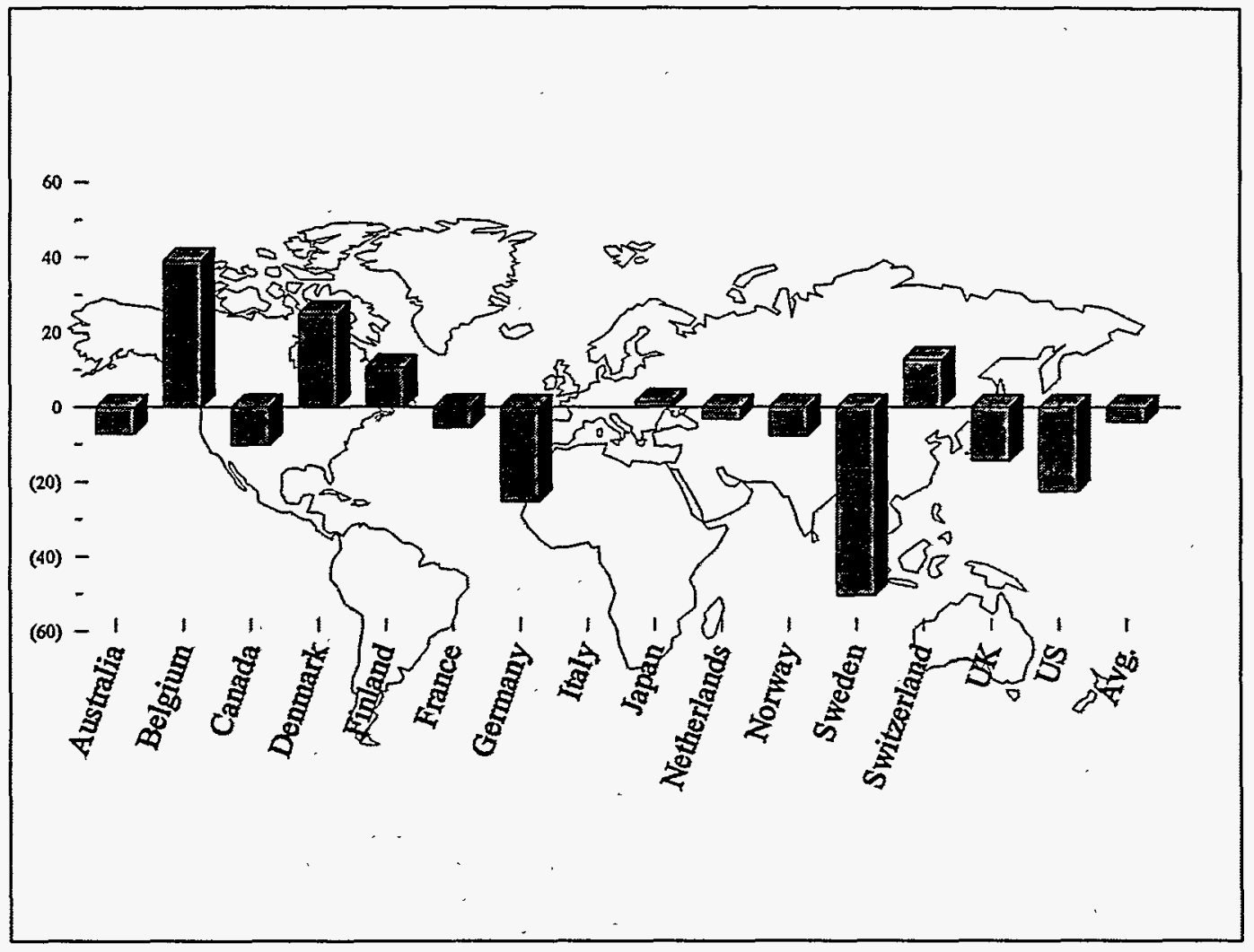

Figure 3.10. Average Annual Rate of Change in Fossil Fuel R\&D Expenditures (1994-1987) 


\subsubsection{Fossil Fuel Expenditures As a percentage of Total R\&D Expenditures}

Figure 3.11 depicts fossil fuel $R \& D$ expenditures as a percentage of total $R \& D$ expenditures for the selected countries. Belgium, Canada, Japan, and Norway all provide fossil fuel $R \& D$ expenditures as a percentage of total $R \& D$ at a level higher than the selected countries average $(0.87 \%)$. Belgium provided a fossil fuel $R \& D$ expenditure of $3.3 \%$ of total R\&D, and Canada allocated $2.1 \%$ of total R\&D towards fossil fuel activities. The Government of Belgium was estimated to spend almost $100 \%$ of its total energy R\&D budget on fossil fuel activities while Canada was estimated to spend approximately $30 \%$. In contrast, Japan provided a relatively low level of total energy $\mathrm{R} \& \mathrm{D}$ on fossil fuel activities (7\%). The Japanese value energy-related R\&D; however, most of that research is not in the fossil fuel sector. Sweden (0.02\%), Germany $(0.14 \%)$, France $(0.21 \%)$, and the United Kingdom $(0.23 \%)$ allocated small levels of funding for fossil fuel $R \& D$ as a percentage of total $R \& D$. The United States provided $0.23 \%$ of its total R\&D budget for fossil fuel activities, well below the average of the selected countries.

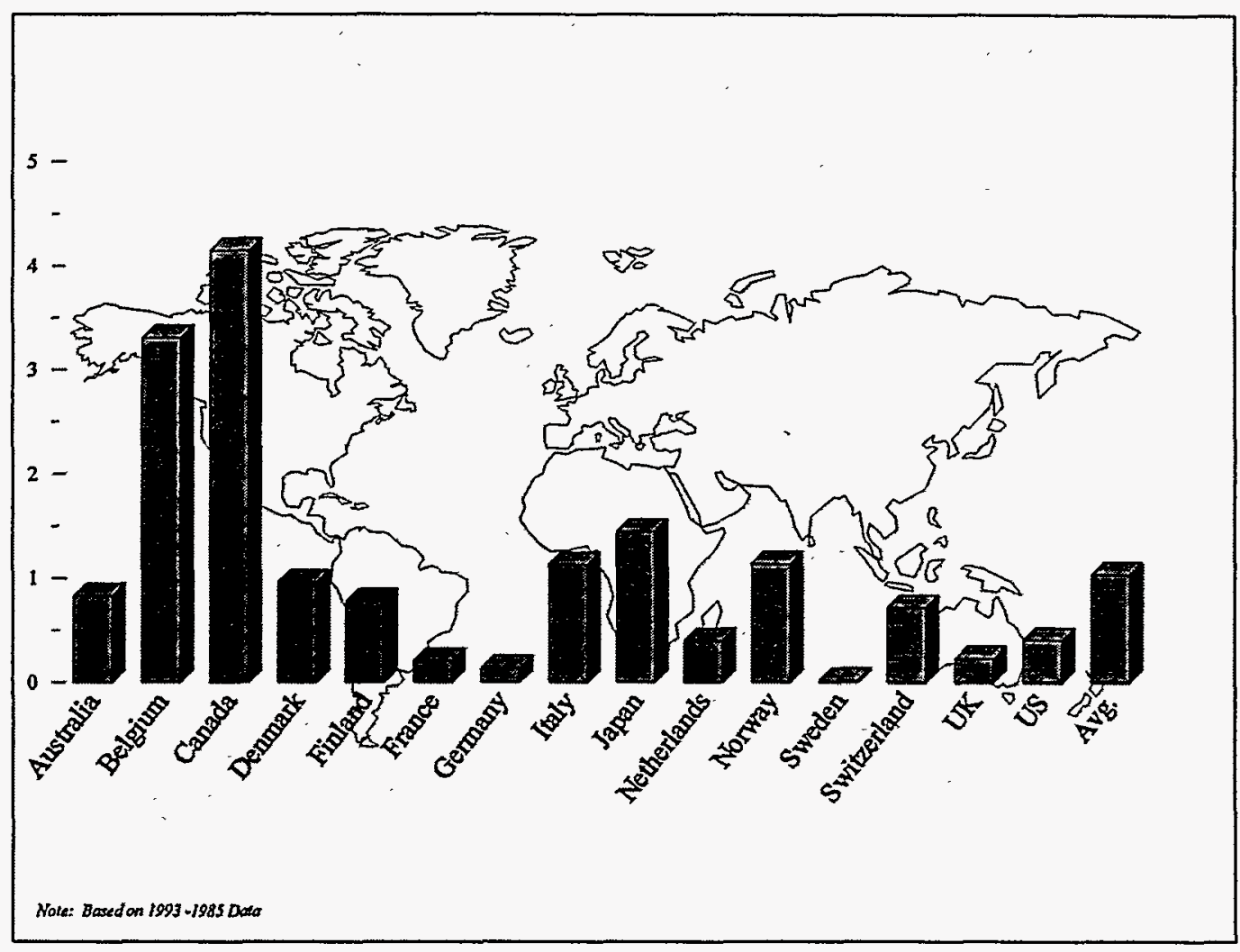

Figure 3.11. 1994 Fossil Fuel R\&D Funding As a Percentage of Total R\&D Expenditures 


\subsection{Fuel Cell}

This section examines R\&D expenditures for total fuel cell, fuel cell expenditures as a percentage of GDP, fuel cell expenditures as a percentage of total R\&D expenditures, and the percentage of fuel cell funding provided by public and private sources. Detailed descriptions of specific fuel cell projects are available for each country in Section 4. $\mathrm{R} \& D$ as a percentage of GDP was multiplied by 1,000 (GDP * 1,000).

\subsubsection{Summary}

Fuel cell R\&D is divided between Japan, the United States, Canada, and Europe. It was estimated that total fuel cell R\&D funding for 1994 was close to US\$543 million, using ERs and US\$429 million using PPPs. Separate estimates on fuel cell R\&D expenditures have indicated 1992 worldwide funding levels of at least US\$400 million. Fuel cell expenditures would have had to increase at an average annual rate over the past few years of approximately $15 \%$. Given the rapidly expanding interest in fuel cells and the increasing dollar value of fuel cell projects, the projected funding levels for 1994 were considered reasonable. The main contributors to the high level of estimated expenditures for fuel cell R\&D in 1994 were private Japanese sources, estimated to account for close to $25 \%$ of the total fuel cell R\&D funding throughout the world. The primary participants in Japanese fuel cell R\&D programs are the Japanese government, utilities, and private companies. Japan contains three of the eleven largest utilities in the world: Tokyo Electric, Kansai Electric, and Chubu Electric. These three power companies had combined 1994 revenues of approximately US $\$ 90$ billion. Fuel cells are a focal technology of each of the electric power companies in Japan, as well as the Japanese government. The Japanese government program is funded through the New Sunshine program managed by NEDO. Forty-three fuel cell projects are discussed in NEDO's annual report, Research and Development on Fuel Cell Power Generation Technology (NEDO 1993). The premier fuel cell projects in Japan include the installation and testing of a $11 \mathrm{MW}$ phosphoric acid fuel cell power plant, the largest in the world, starting in 1989 and the development of a $5 \mathrm{MW}$ class of fuel cell power plants for use in an urban energy center.

The U.S. maintains strong fuel cell R\&D programs through programs funded by the USDOE and DOD, the National Aeronautics and Space Administration, EPRI, GRI, and such private companies as Westinghouse, International Fuel Cells (IFC), Energy Research Corporation (ERC), MC Power, and Allied Signal. The U.S. provides R\&D funding for all of the primary types of fuel cells. 
Canada maintains a high level of fuel cell $R \& D$ through the work of Ballard Power Systems, which has projected a total funding level of US\$125 million on fuel cell R\&D over $1994-1997$ (US\$/yr. 31.25 million). The main focus of Ballard's research is development of a bus powered by polymer electrolyte fuel-cell stacks.

Germany, Italy, Denmark, Norway, Netherlands, and the United Kingdom have welldeveloped, fuel-cell R\&D programs. The European Commission (EC) funds fuel-cell R\&D programs throughout Europe under its Joule-II, Brite-EURAM, and Thermie programs, as well as participating in the Euro Quebec Hydrogen Hydro Pilot Project (EQHHPP). Solid oxide, molten carbonate, and polymer electrolyte fuel-cell technologies are the primary focus of $R \& D$ funding throughout Europe.

Table 3.2 indicates the major fuel cell funders throughout the selected countries.

Table 3.2. Major Fuel Cell Funding Organizations by Country

\begin{tabular}{|c|c|c|}
\hline Country & Funding Organization & Principal Fuel-Cell Technology \\
\hline Australia & Government & SOFC \\
\hline Belgium & $\begin{array}{l}\text { Elenco } \\
\text { VITO }\end{array}$ & $\begin{array}{l}\text { AFC } \\
\text { PEFC }\end{array}$ \\
\hline Canada & $\begin{array}{l}\text { Government } \\
\text { Ballard Power Systems, Inc. } \\
\text { Canadian Electrical Association }\end{array}$ & $\begin{array}{l}\text { NA } \\
\text { PEFC } \\
\text { SOFC }\end{array}$ \\
\hline Denmark & $\begin{array}{l}\text { Government } \\
\text { Elkraft } \\
\text { Elsam } \\
\text { Haldor Topsoe } \\
\text { Riso Research Center } \\
\text { Innovision A/S } \\
\text { Naturgas Syd }\end{array}$ & $\begin{array}{l}\text { SOFC, } \\
\text { MCFC } \\
\text { PAFC, SOFC } \\
\text { ALL } \\
\text { SOFC } \\
\text { SOFC, DMFC } \\
\text { PAFC }\end{array}$ \\
\hline Finland & IVO & PAFC \\
\hline France & $\begin{array}{l}\text { Government } \\
\text { Ademe (ECOTECH) } \\
\text { CEA } \\
\text { Gaz de France } \\
\text { EDF } \\
\text { Sorapec }\end{array}$ & $\begin{array}{l}\text { PEFC } \\
\text { DMFC, PEFC } \\
\text { PEFC } \\
\text { PEFC } \\
\text { NA } \\
\text { PEFC }\end{array}$ \\
\hline
\end{tabular}


Table 3.2. Continued.

\begin{tabular}{|c|c|c|}
\hline Country & Funding Organization & Principal Fuel-Cell Technology \\
\hline Germany & $\begin{array}{l}\text { Government } \\
\text { Siemens } \\
\text { Dornier } \\
\text { MTU } \\
\text { Daimler Benz } \\
\text { BMW } \\
\text { KFA Julich } \\
\text { Ruhrgas } \\
\text { Thyssengas } \\
\text { Hoescht } \\
\text { KTI/Solar } \\
\text { Deutsche Aerospace } \\
\text { HEAG }\end{array}$ & $\begin{array}{l}\text { All } \\
\text { PEFC, DMFC, AFC, SOFC } \\
\text { SOFC } \\
\text { MCFC } \\
\text { PEFC } \\
\text { PEFC } \\
\text { PEFC } \\
\text { PAFC } \\
\text { PAFC } \\
\text { AFC } \\
\text { PAFC } \\
\text { MCFC } \\
\text { PAFC }\end{array}$ \\
\hline Italy & $\begin{array}{l}\text { Government } \\
\text { ENEA } \\
\text { DeNora } \\
\text { Ansaldo } \\
\text { Fiat/Avio } \\
\text { Eniricerche } \\
\text { Acoser } \\
\text { CLC } \\
\text { Tecnars }\end{array}$ & $\begin{array}{l}\text { MCFC, SOFC, PAFC, PEFC } \\
\text { MCFC, SOFC, PAFC } \\
\text { PEFC } \\
\text { AFC, PEFC } \\
\text { PEFC } \\
\text { PAFC } \\
\text { PAFC } \\
\text { PAFC } \\
\text { PEFC }\end{array}$ \\
\hline Japan & $\begin{array}{l}\text { Government } \\
\text { Tokyo Elec. Power Co. } \\
\text { Kansai Elec. Power Co. } \\
\text { Chubu Elec. Power Co. } \\
\text { Tohoku Elec. Power Co. } \\
\text { PAFC Technology Research } \\
\text { Association } \\
\text { Tokyo Gas } \\
\text { Mitsubishi } \\
\text { Fuji } \\
\text { Hitachi } \\
\text { Ishikawajima-Harima Heavy } \\
\text { Ind., Ltd. } \\
\text { Sanyo } \\
\text { MCFC Tech. Res. Association }\end{array}$ & $\begin{array}{l}\text { PAFC, MCFC, SOFC, PEFC } \\
\text { PAFC, MCFC. SOFC } \\
\text { PAFC, MCFC, SOFC } \\
\text { PAFC } \\
\text { PAFC } \\
\text { PAFC } \\
\text { PAFC } \\
\text { PAFC } \\
\text { PAFC } \\
\text { MCFC } \\
\text { MCFC } \\
\text { MCFC } \\
\text { MCFC }\end{array}$ \\
\hline Netherlands & $\begin{array}{l}\text { Government } \\
\text { Kinetics Technology Intern. } \\
\text { (KTI) } \\
\text { ECN } \\
\text { BCN } \\
\text { TNO }\end{array}$ & $\begin{array}{l}\text { NA } \\
\text { PAFC } \\
\text { SOFC, MCFC, PEFC } \\
\text { MCFC } \\
\text { SOFC, PEFC }\end{array}$ \\
\hline
\end{tabular}


Table 3.2 Continued

\begin{tabular}{|c|c|c|}
\hline Country & \begin{tabular}{|l|} 
Funding Organization \\
\end{tabular} & \begin{tabular}{|l} 
Principal Fuel-Cell Technology \\
\end{tabular} \\
\hline Norway & $\begin{array}{l}\text { Government } \\
\text { Statoil }\end{array}$ & $\begin{array}{l}\text { SOFC } \\
\text { SOFC }\end{array}$ \\
\hline Sweden & $\begin{array}{l}\text { Government (NUTEK) } \\
\text { Vattenfall } \\
\text { Sydkraft }\end{array}$ & $\begin{array}{l}\text { MCFC } \\
\text { MCFC, PAFC } \\
\text { MCFC, PAFC }\end{array}$ \\
\hline Switzerland & $\begin{array}{l}\text { Government } \\
\text { Sulzer } \\
\text { SIG }\end{array}$ & $\begin{array}{l}\text { SOFC } \\
\text { SOFC } \\
\text { PAFC }\end{array}$ \\
\hline United Kingdom & $\begin{array}{l}\text { Government / ETSU } \\
\text { Rolls Royce } \\
\text { British Gas } \\
\text { Johnson Matthey } \\
\text { AEA Technology } \\
\text { VSEL } \\
\text { CJB } \\
\text { Cookson } \\
\text { GEC Alsthom }\end{array}$ & $\begin{array}{l}\text { SOFC, PEFC } \\
\text { SOFC, PEFC } \\
\text { SOFC, MCFC, PEFC } \\
\text { PEFC } \\
\text { PEFC } \\
\text { PEFC } \\
\text { PEFC } \\
\text { SOFC } \\
\text { SOFC }\end{array}$ \\
\hline United States & $\begin{array}{l}\text { Government (USDOE, DOD, } \\
\text { NASA) } \\
\text { Fuel Cell Commercialization } \\
\text { Group } \\
\text { ERC } \\
\text { GRI } \\
\text { MC Power } \\
\text { Westinghouse } \\
\text { Allied Signal } \\
\text { IFC } \\
\text { EPRI } \\
\text { H Power } \\
\text { EP Fuel Cells }\end{array}$ & $\begin{array}{l}\text { All } \\
\text { MCFC } \\
\text { MCFC } \\
\text { All } \\
\text { MCFC } \\
\text { SOFC } \\
\text { SOFC } \\
\text { PAFC } \\
\text { All } \\
\text { NA } \\
\text { PEFC }\end{array}$ \\
\hline
\end{tabular}

\subsubsection{Total Expenditures}

Japan and the U.S. are the world's leaders in fuel cell R\&D funding. Japan was estimated to have spent approximately US\$204 million and the U.S. approximately US\$150 million on fuel cell R\&D projects in 1994. Utilizing PPPs, the Japanese allocation for fuel cell R\&D projects decreases to US\$109 million. Japan and the U.S. accounted for close to two thirds of the total funding for fuel cell R\&D. Germany, Italy, and Canada funded fuel-cell R\&D projects at levels of US\$30-53 million in 1994. The Netherlands, France, 
Denmark, and the United Kingdom support fuel cell R\&D at approximate levels of US\$10-20 million/year. Australia, Belgium, Finland, Norway, Sweden, and Switzerland all have programs of less than US\$5 million/year. In total, Europe was estimated to have spent approximately US\$155 million on fuel cell R\&D, a considerable increase over a 1992 estimation of US\$64 million made by the EU at the 1992 International Fuel Cell Conference in Japan (Michael 1994). Figure 3.12 depicts the levels of expenditures on fuel cell R\&D converted to US\$ by ERs and PPPs for the selected countries.

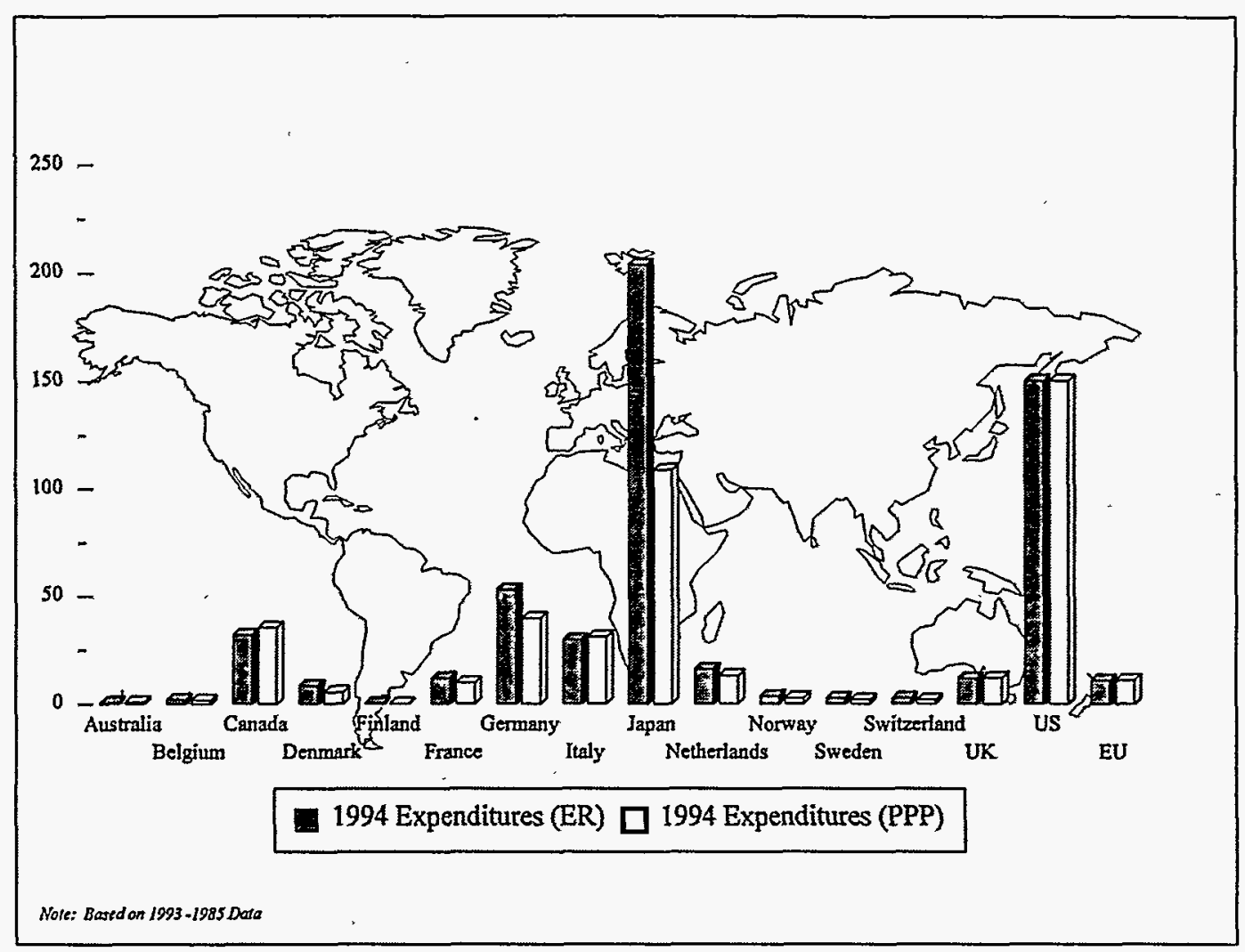

Figure 3.12. 1994 World Fuel Cell R\&D Expenditures (US\$ million)

\subsubsection{Expenditures As a Percentage of GDP}

Figure 3.13 displays fuel cell expenditures as a percentage of GDP for the selected countries. Denmark, Canada, and the Netherlands allocated the largest expenditures for fuel cell R\&D as a percentage of GDP in 1994. Denmark allocated 6.2\% of GDP (GDP * 1,000 ), the highest of any country. Overall, the average contribution to fuel cell R\&D as a percentage of GDP (GDP * 1,000) in 1994 was $2.9 \%$. Japan, Norway, and Italy allocated levels of fuel cell R\&D as a percentage of GDP at levels above the average. The U.S. allocated 2.2\% of GDP to fuel cell R\&D in 1994. 


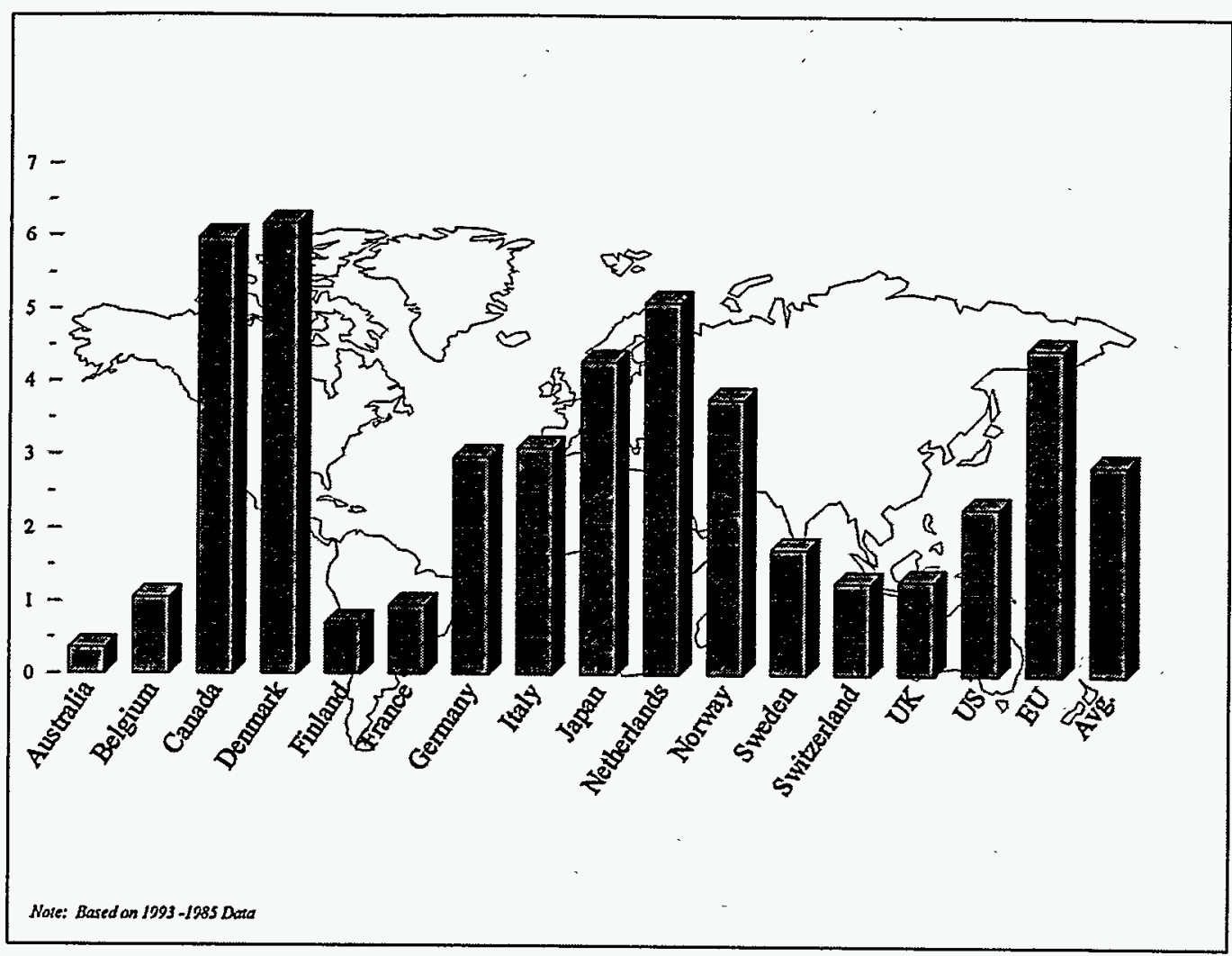

Figure 3.13. 1994 World Fuel Cell R\&D As a Percentage of GDP (GDP*1,000)

\subsubsection{Expenditures As a Percentage of Total R\&D Expenditures}

Figure 3.14 indicates fuel-cell $R \& D$ expenditures as a percentage of total $R \& D$ expenditures for the selected countries. Canada contributed the highest percentages of R\&D funds towards fuel cell activities (0.47\%). Denmark, Netherlands, Norway, and Italy also contributed high levels. All other selected countries allocated less than $0.1 \%$ of total R\&D funding. The U.S. allocated $0.09 \%$ of total R\&D to fuel cells. The average contribution for fuel cell R\&D as a percentage of total R\&D was $0.12 \%$. 


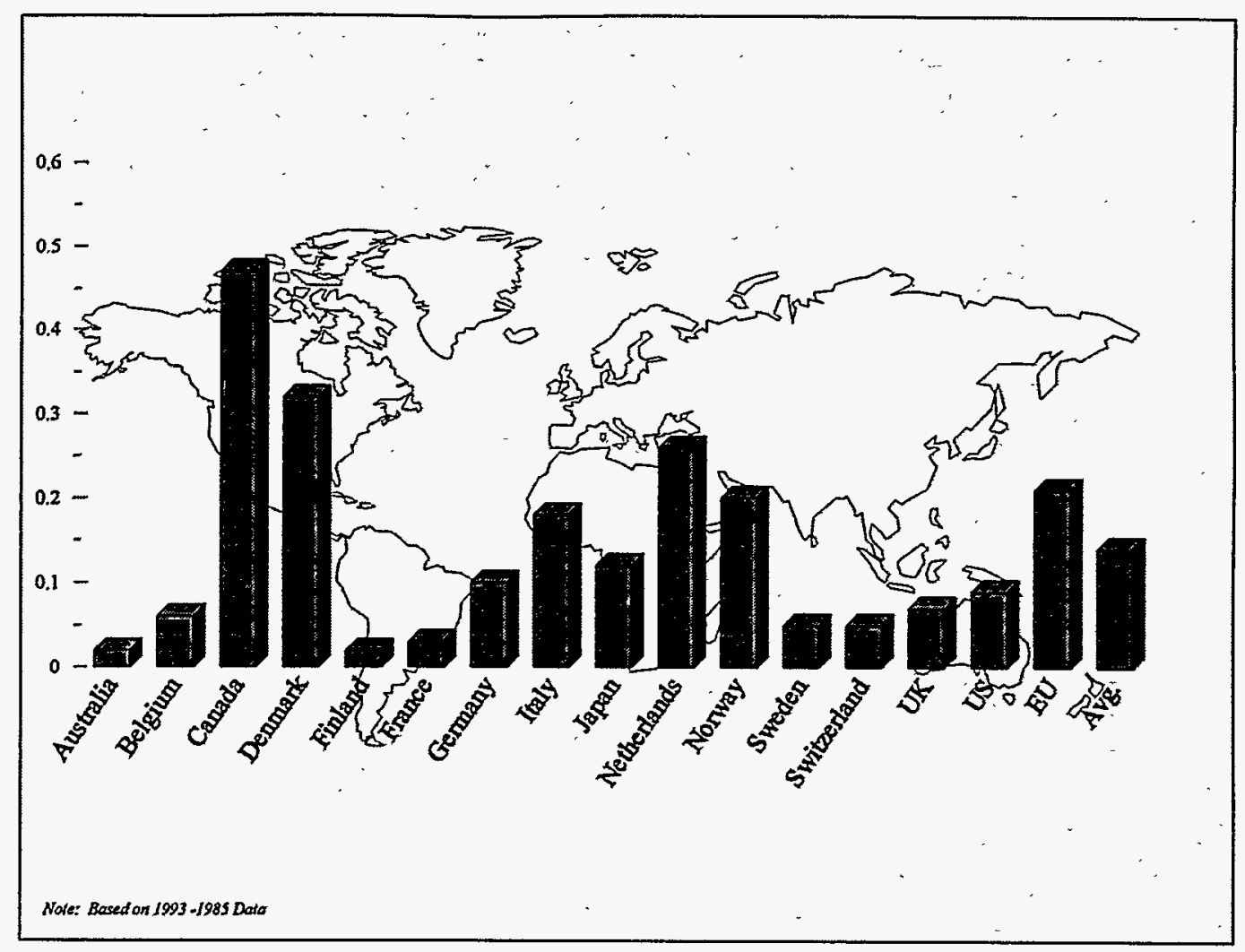

Figure 3.14. 1994 Fuel Cell R\&D As a Percentage of Total R\&D Expenditures

\subsubsection{Trends in Fuel Cell R\&D Expenditures}

Expenditures on Fuel Cell R\&D projects indicated an increasing level of investment over the past several years. Developments of significant programs in Europe and Canada have contributed to a fuel-cell R\&D community previously dominated by the U.S. and Japan. A 1992 estimate by the EU indicated a total fuel cell R\&D expenditure in Europe of US\$64 million (Michael 1994). The K\&M estimated level for 1994 in Europe was close to US $\$ 155$ million. Large programs funded by Seimens, Ansaldo, Daimler Benz, and the EU have contributed to the growth in fuel cell R\&D throughout Europe. Japan and the U.S. are contributing more to fuel cell R\&D as the technology moves from applied research to development and commercialization. In total, approximately 225-250 fuel cell projects are being funded throughout the selected countries. In addition, the EU and the OECD/IEA have fuel-cell development programs in which most of the selected countries participate. Considering the increased interest and funding for fuel cell activities, it is likely that fuel-cell R\&D expenditures will continue to increase throughout the world. 


\subsubsection{Public and Private Contributions}

Figure 3.15 depicts public and private contributions to fuel-cell R\&D in the selected countries. Most funding is obtained from private sources throughout the world. Private Japanese funding sources were estimated to account for almost $65 \%$ of Japanese fuel-cell $R \& D$ funding in 1994, approximately $30 \%$ of the total fuel-cell R\&D funding within the selected countries. Belgium, Canada, Denmark, Finland, Sweden, and the United Kingdom have fuel cell programs funded almost entirely by private sources. Germany and Norway relied on private funding sources to provide $82 \%$ and $78 \%$, respectively, of fuel-cell R\&D funding. In contrast, Australia, France, Netherlands, and the United States all rely on public funding sources to provide more than $50 \%$ of fuel-cell $R \& D$ funding.

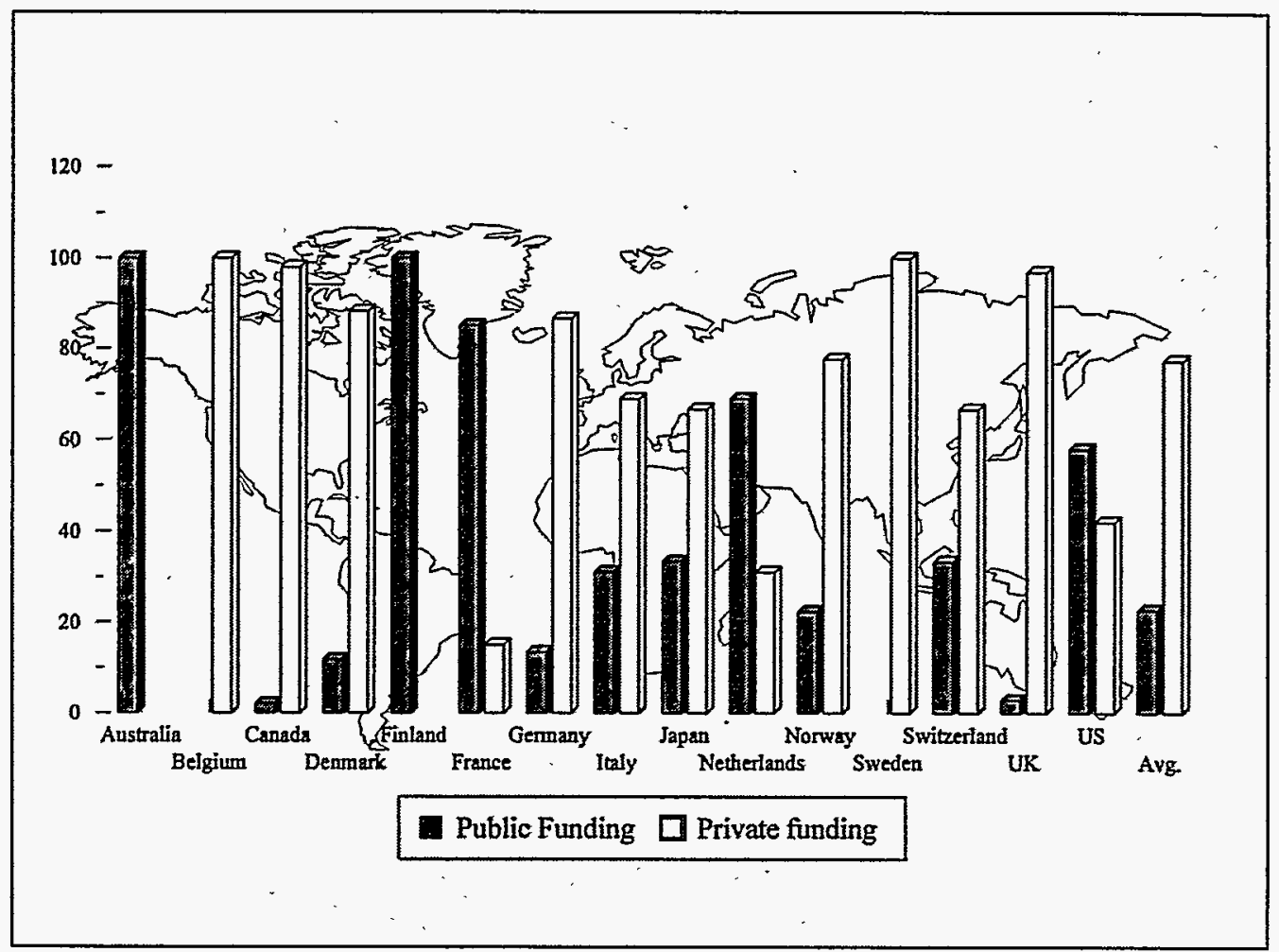

Figure 3.15. Public and Private Contributions to Fuel-Cell R\&D Expenditures (\% of Total)

\subsection{Advanced Gas Turbine}

This section examines R\&D expenditures for total advanced gas turbine, advanced gas turbines as a percentage of GDP, average annual percent change in advanced gas turbine 
funding, and advanced gas turbine expenditures as a percentage of total R\&D expenditures.

\subsubsection{Summary}

Advanced gas turbine is supported primarily by large private corporations. General Electric, ABB, Seimens, European Gas Turbines, Westinghouse, Hitachi, and Rolls Royce lead in such support. The federal governments of the Netherlands (60\%), France (22.9\%), Japan (19.5\%), Germany (6.5\%), and the United States (6.2\%) supported advanced gas turbine R\&D at the highest levels as a percentage of total advanced gas turbine R\&D funding. Figure 3.16 depicts the relationships between the large gas turbine manufacturing companies of the world and their R\&D funding for advanced gas turbines. The companies have agreements concerning technology transfer, joint development of combustion turbine technology, marketing, manufacturing, or have an equity stake in another company. Although many other companies sell and repackage gas turbines, Figure 3.16 depicts those that perform significant $R \& D$ on gas turbines.

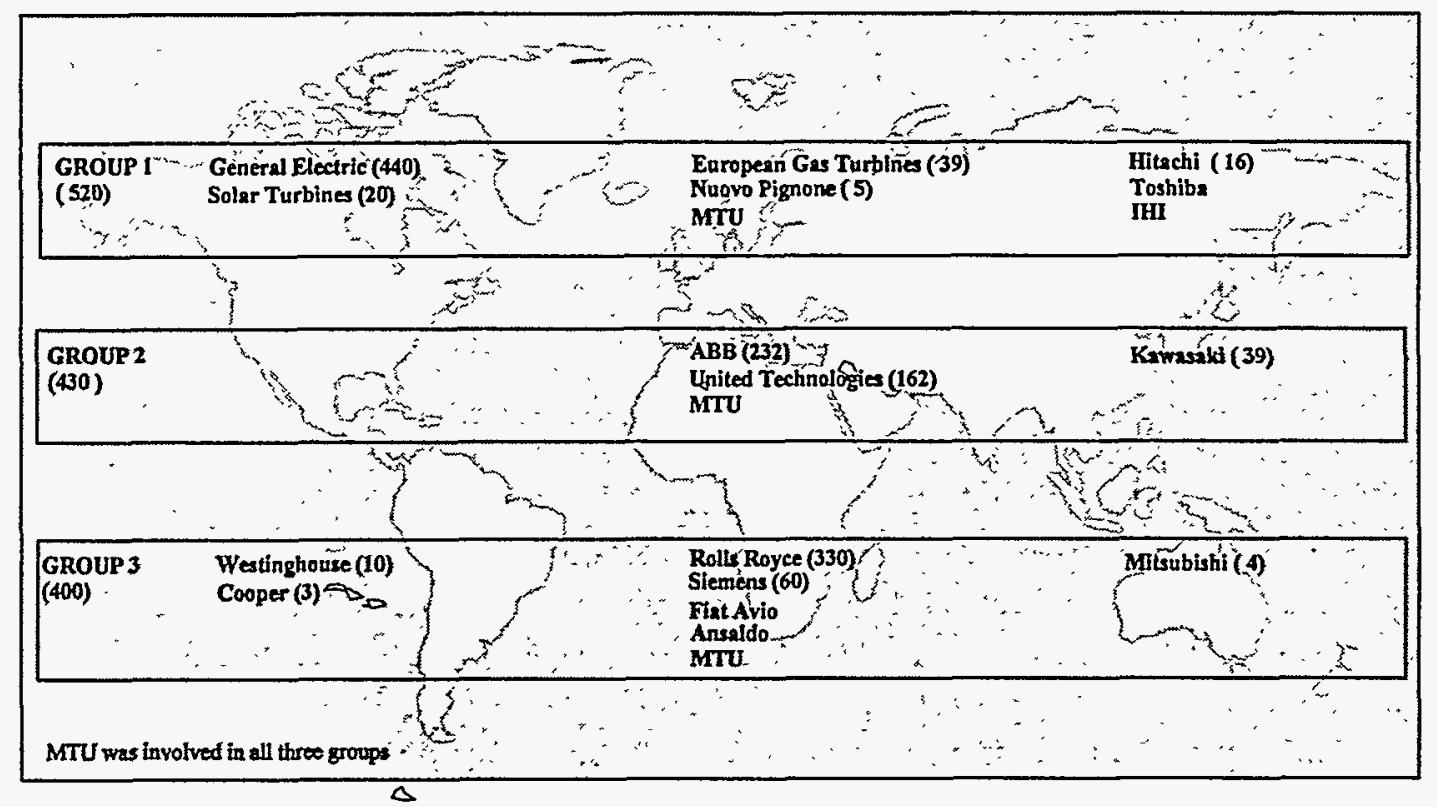

Figure 3.16. Major Gas Turbine Manufacturers, Their Relationships, and Advanced Gas Turbine R\&D Expenditures (US\$ millions)

The General Electric (U.S.) gas turbine program has links to the following companies: Solar Turbines (U.S.), European Gas Turbines (United Kingdom, France, and the U.S.), Nuovo Pignone (Italy), Deutsch Aerospace/MTU (Germany), IHI (Japan), Toshiba (Japan), and Hitachi (Japan). European Gas Turbines is $10 \%$ owned and Nuovo Pignone 
was recently purchased by General Electric. Hitachi repackages and sells large-frame General Electric gas turbines. Solar Turbines participates in a cooperative technology development agreement with General Electric. Toshiba is a member of the Manufacturing Associates of General Electric. IHI is a revenue-share partner for the GE90 and is licensed for delivery of the LM500 gas turbine. MTU has worked with General Electric in the development of high-pressure components for the CF6-80C engine (International Gas Turbine Institute 1993). The estimated total R\&D expenditures of these companies was US $\$ 520$ million, of which approximately $85 \%$ was supplied by General Electric.

ABB (Sweden and Switzerland), United Technologies (United Kingdom), and Kawasaki (Japan) were estimated to have spent approximately US $\$ 430$ million on advanced gas turbine R\&D in 1994. Included under the United Technologies umbrella are Pratt Whitney (United Kingdom), Turbomecca, and Ulstein Turbine (Germany). Man GHH of Germany is also included in this group but was considered to make only negligible R\&D funding contributions.

Westinghouse (U.S.), Rolls Royce (United Kingdom), Fiat Avio (Italy), Siemens (Germany) and Mitsubishi (Japan) spent roughly US\$400 million on advanced gas turbine R\&D. Westinghouse signed a 15-year agreement with Rolls Royce for technology transfer, joint development of combustion turbine technology, and marketing of combustion turbines and combined cycle power plants (International Gas Turbine Institute 1993). A trilateral agreement between Westinghouse, Fiat Avio, and Mitsubishi provides for cooperation in joint development programs for combustion turbines. Allison Engine, formerly of General Motors Corporation, was recently purchased by Rolls Royce and any gas turbine R\&D performed by Allison was considered Rolls Royce R\&D. Seimens works in cooperation with Ansaldo (Italy) and recently announced a gas turbine agreement with Westinghouse. MTU has had an agreement with Pratt Whitney (United Technologies) and Fiat Avio since 1977 for the design, development, and production of turbines/engines.

General Electric, Rolls Royce, ABB, and United Technologies were estimated to have the highest levels of expenditures on advanced gas turbine R\&D. In 1993, ABB appropriated US $\$ 2.3$ billion to R\&D, $8.1 \%$ of total sales (US $\$ 28$ billion). ABB considered gas turbine $R \& D$ an operating expense within the power plant division that had total sales of US\$8 billion. The power plant division was determined to spend approximately US\$640 million on R\&D, of which US\$230 million was determined to involve advanced gas turbine R\&D. In comparison, General Electric had total sales of US $\$ 40$ billion in 1993 and product line (Marine and Industrial Engines and Power Systems) sales of US $\$ 13.3$ billion. GE's product-line sales were approximately $165 \%$ of $A B B$ 's product line sales. In addition, GE's product line did not include any nuclear or fossil power plants but was focused more on gas turbines. Therefore, GE's estimated R\&D expenditures on advanced gas turbines were US $\$ 442$ million. Rolls Royce had sales of US $\$ 3.5$ billion and R\&D expenditures of US $\$ 253$ million in 1993 . US $\$ 215$ million of Rolls Royce's total R\&D was estimated to be devoted to advanced gas turbine 
projects. United Technologies had sales of close to US\$21 billion of which $\$ 6$ billion came from their Pratt \& Whitney division. Approximately, US\$1.1 billion were supplied for total R\&D by United Technologies, of which $\$ 162$ million was estimated for advanced gas turbine $R \& D$.

The U.S. and the United Kingdom are homes to the three of the world's four largest gas turbine companies. General Electric (U.S.), Rolls Royce (U.K.), and United Technologies (UK) had a combined level of total sales close to US\$65 billion. The total R\&D budgets of these three companies is almost US $\$ 3$ billion. $A B B$ is owned in equal parts by the two companies: Asea $A B$ and $B B C$ Brown Boveri Ltd. Asea $A B$ is headquartered in Sweden and BBC Brown Boveri Ltd. is centered in Switzerland. ABB has R\&D centers in Finland, Germany, Italy, Norway, Sweden, and Switzerland; however, the source of R\&D funding is located in one of the two company headquarters, Sweden or Switzerland. Japanese companies involved in gas turbine R\&D include Hitachi, Mitsubishi, IHI, Toshiba, and Kawasaki. German companies involved with gas turbine R\&D include Siemens and Motoren- und turbinen-Union Friedrichshafen GmbH (MTU).

\subsubsection{Total Expenditures}

Figure 3.17 depicts advanced gas turbine R\&D expenditures for the selected countries, which amounted to approximately US $\$ 1.5$ billion in 1994 . The United States and United Kingdom are the world's leaders in such expenditures. The U.S. is home to three major

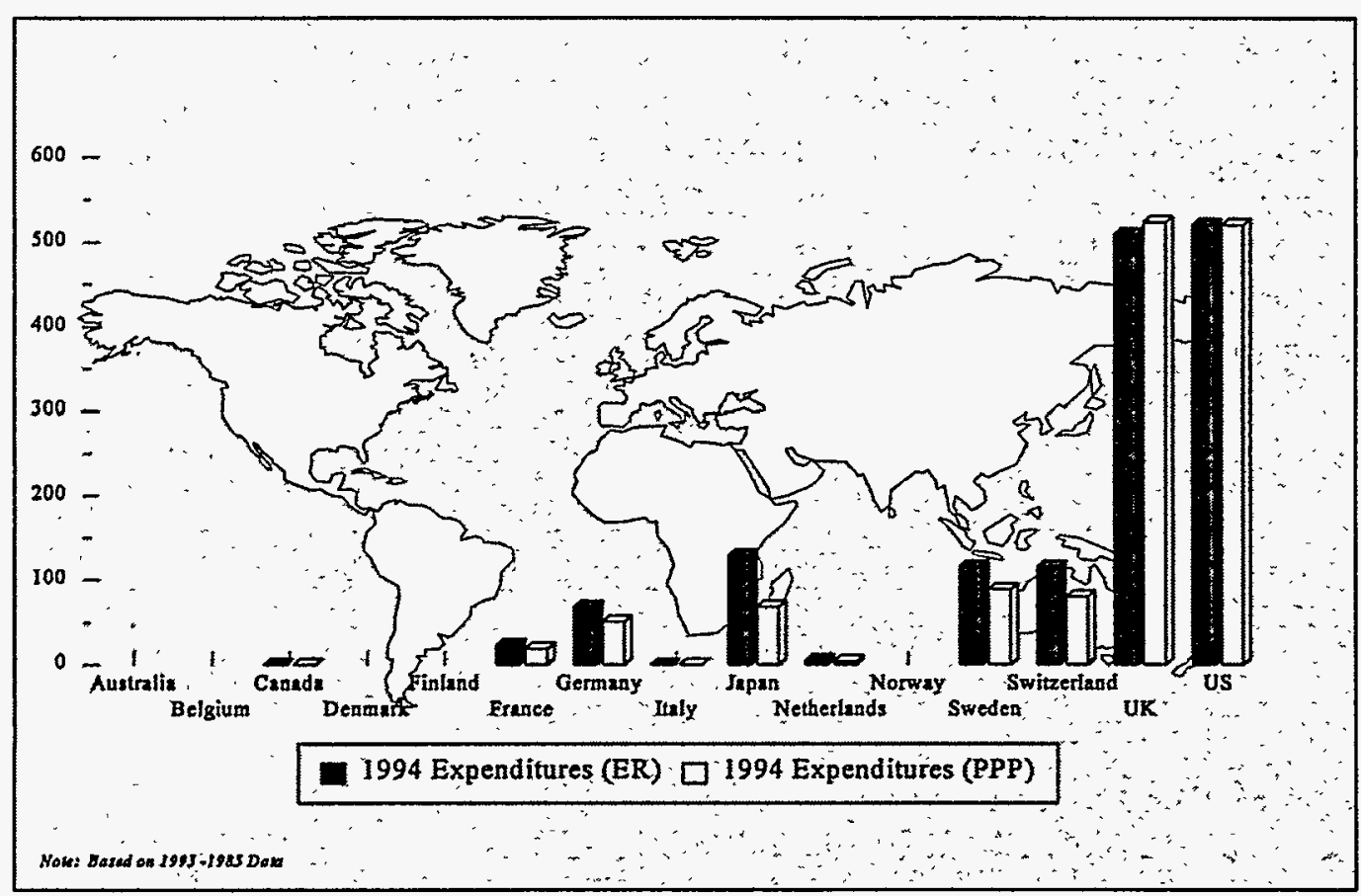




\section{Figure 3.17. 1994 World Advanced Gas Turbine R\&D Expenditures (US\$ million)}

gas turbine manufacturing companies: General Electric, Westinghouse, and Solar Turbines. The U.K. houses the gas turbine companies of Rolls Royce and United Technologies. The source for all gas turbine research conducted by any of these companies or their subsidiaries was considered either the U.S. or the U.K. As a result, it was estimated that the U.S. spent close to US\$521 million and the U.K. approximately US $\$ 510$ million (ER) on advanced gas turbine R\&D in 1994. Utilizing PPPs, the U.K. spent US $\$ 524$ million in 1994, the highest in the world. In the U.K., $100 \%$ of advanced gas turbine R\&D is privately funded; in the U.S. private funding is more than $90 \%$. Japan, Sweden, Switzerland, and Germany also had high levels of advanced gas turbine R\&D in 1994. Approximately $98 \%$ of the total level of advanced gas turbine R\&D funding was determined to originate in one of these six countries. Negligible expenditures were reported in Australia, Belgium, Denmark, Finland, Canada, and Italy. The Pratt Whitney facility in Canada was considered under the U.K. umbrella due to its ownership by United Technologies. Nuovo Pignone of Italy is majority-owned by General Electric; therefore, all R\&D expenditures were included under General Electric.

\subsubsection{Expenditures As a Percentage of GDP}

Figure 3.18 indicates advanced gas turbine R\&D as a percentage of GDP (GDP * $\$ 1,000$ ) for the selected countries. Sweden, United Kingdom, and Switzerland allocated gas turbine R\&D as a percentage of GDP at levels greater than $48 \%$. In comparison, the United States allocated approximately $7.9 \%$ of GDP on advanced gas turbine R\&D in 1994. General Electric does not have the same central role in the U.S. economy as do ABB, Rolls Royce, and United Technologies in their home-country economics. Germany, Japan, France, and the Netherlands all allocated 2-6\% of GDP on advanced gas turbine R\&D.

\subsubsection{Expenditures As a Percentage of Total R\&D Expenditures}

Figure 3.19 shows advanced gas turbine R\&D expenditures as a percentage of total R\&D for the selected countries. The U.K., Sweden, and Switzerland allocated the highest levels (greater than 1.75\%) in 1994. These three countries gave the highest level of importance to gas turbine R\&D, relative to all other R\&D areas. The U.S. and Germany allocated 0.31 and $0.2 \%$, respectively. Japan, Netherlands, France, and Norway allocated 0.04-0.09\%. Although the absolute expenditures of France, Germany, Japan, Netherlands, Norway, and in United States varied greatly, the percentages of total R\&D allocated to advanced gas turbines were similar. 


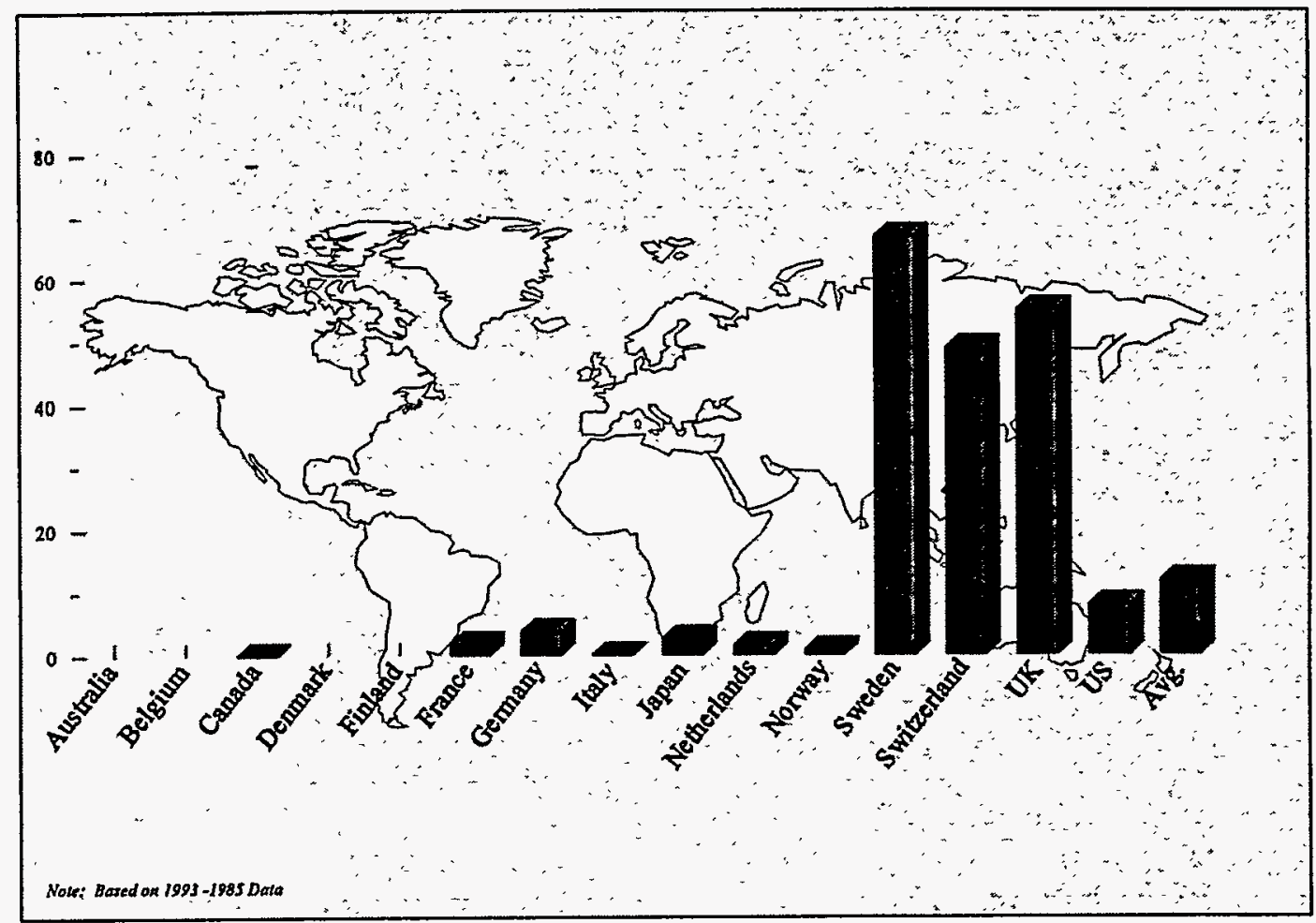

Figure 3.18. 1994 World Advanced Gas Turbine R\&D As a Percentage of GDP (GDP*1,000)

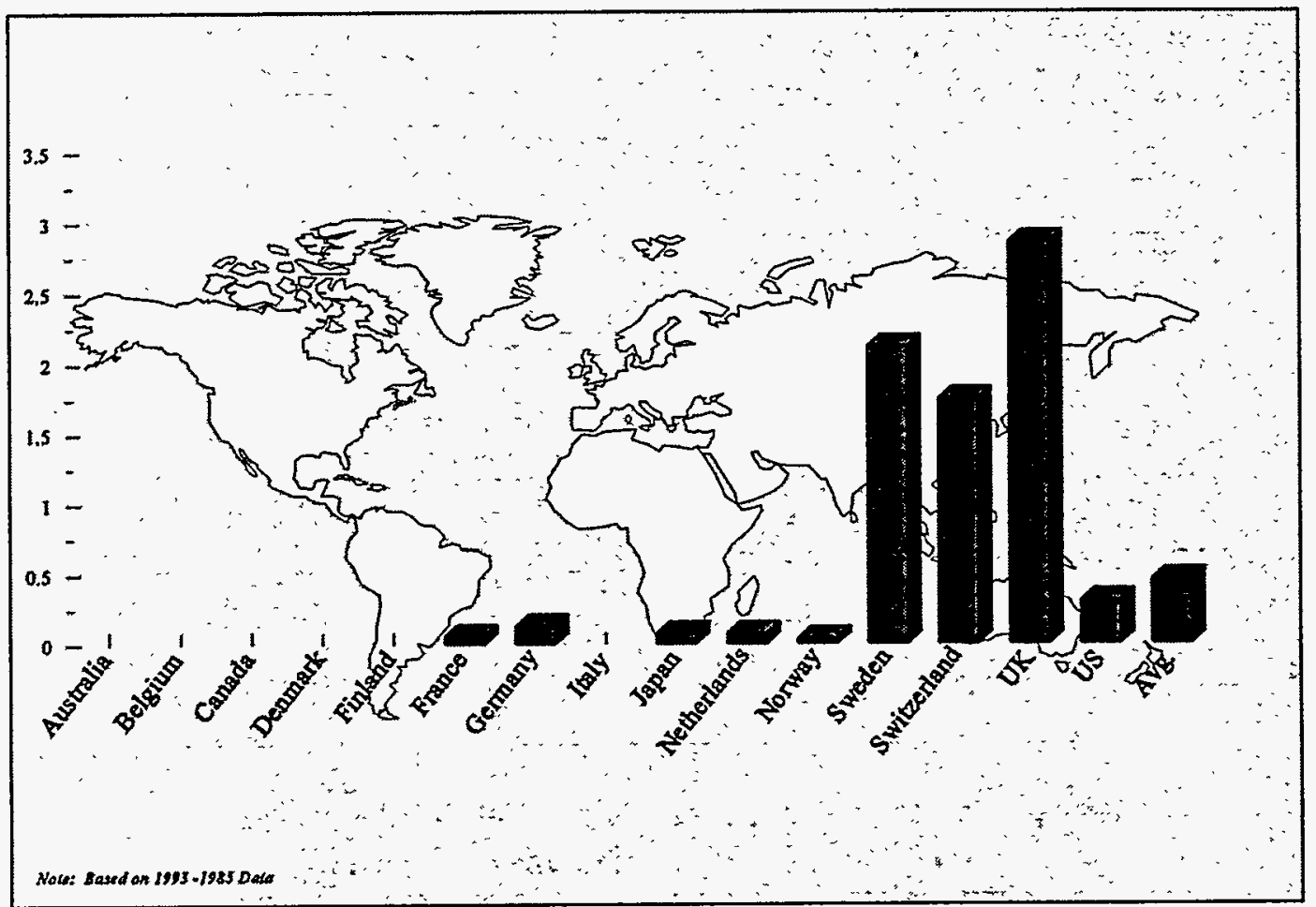

Figure 3.19. 1994 Advanced Gas Turbine R\&D Funding As a Percentage of Total R\&D Expenditures 


\subsubsection{Trends in Expenditures}

Lack of accurate, past levels of contributions for advanced gas turbine R\&D from the major gas turbine manufacturing companies made analysis of trends unfeasible.

However, given the high projected levels of gas use for generating electricity and the large areas of potential improvement over today's technologies, private companies will likely continue to appropriate funding for R\&D of advanced gas turbine technology.

\subsubsection{Public and Private Contributions}

Figure 3.20 contains public and private contributions to advanced gas turbine $R \& D$ for the selected countries. The majority of funding is provided by private sources throughout the world. Six countries account for approximately $98 \%$ of funding. In these countries, an average of approximately $95 \%$ of funding is from private sources. On average, $72 \%$ of advanced gas turbine $R \& D$ was from private sources throughout the selected countries. The highest levels of public support as a percentage of total support were in the Netherlands, France, and Japan. Small government-funded projects in Norway and Italy accounted for $100 \%$ of the advanced gas turbine R\&D in those countries.

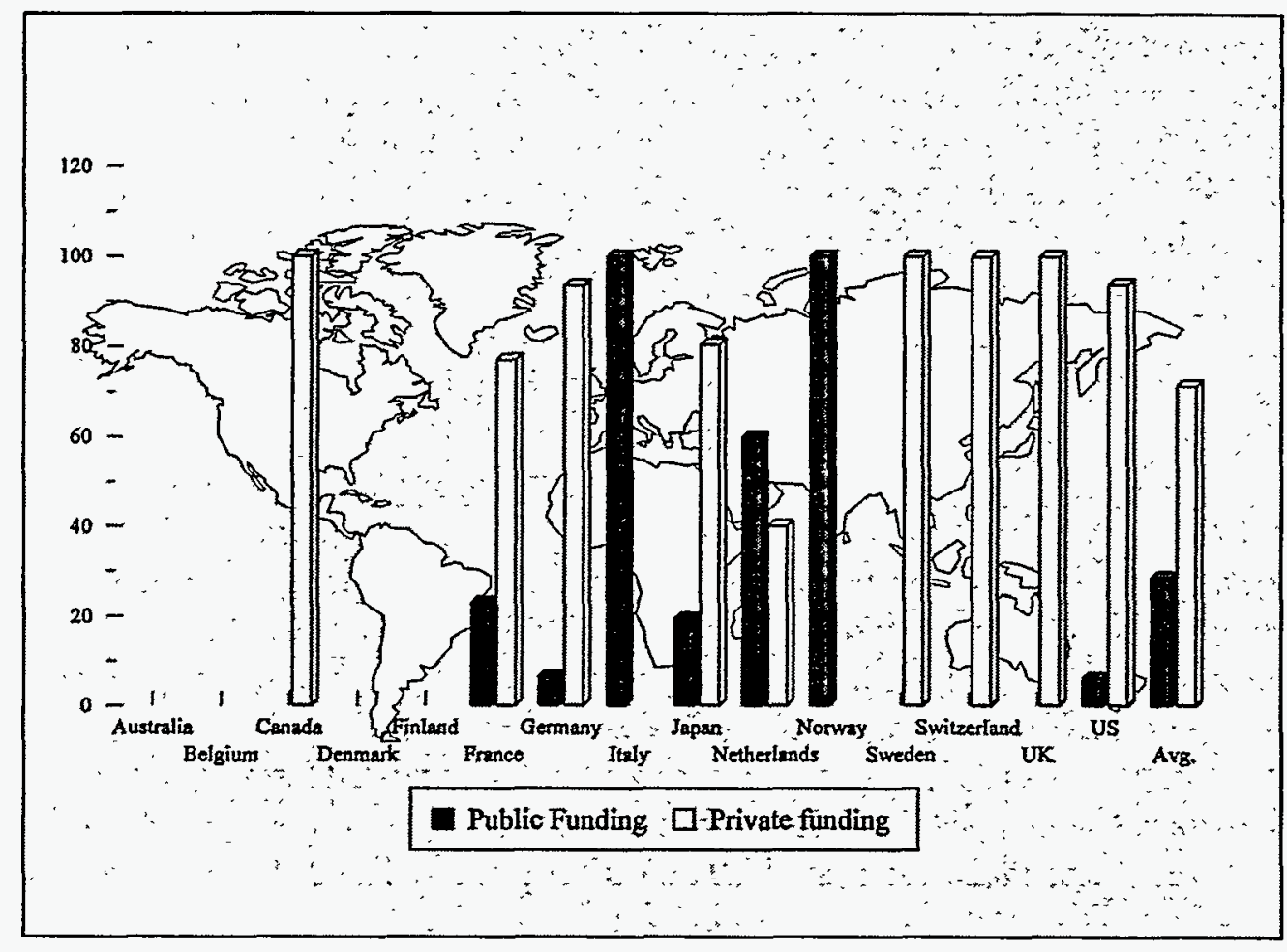

Figure 3.20. Public and Private Contributions to Advanced Gas Turbine R\&D Expenditures (\% of Total) 


\section{Country Reports}

The country reports provide an overview of the energy $R \& D$ program within each selected country (See Figure 4.1) and present the role of fuel cells and advanced gas turbines in the overall energy program. For each of the selected countries, a detailed description is provided in the following areas:

- R\&D expenditures for total energy, fossil fuel, fuel cells, and advanced gas turbines.

- Organizational structure of R\&D funding

- Electricity generation methods, breakdown of overall energy R\&D by specific program areas and trends in energy $R \& D$ funding (future electricity generation projections are taken from the IEA of the OECD).

- Fuel cell and advanced gas turbine projects, funding levels, and trends spending.

The country reports are intended to provide not only profiles of $R \& D$ programs within countries but also provide a means for measurement of a country's R\&D program versus the baseline of the United States.

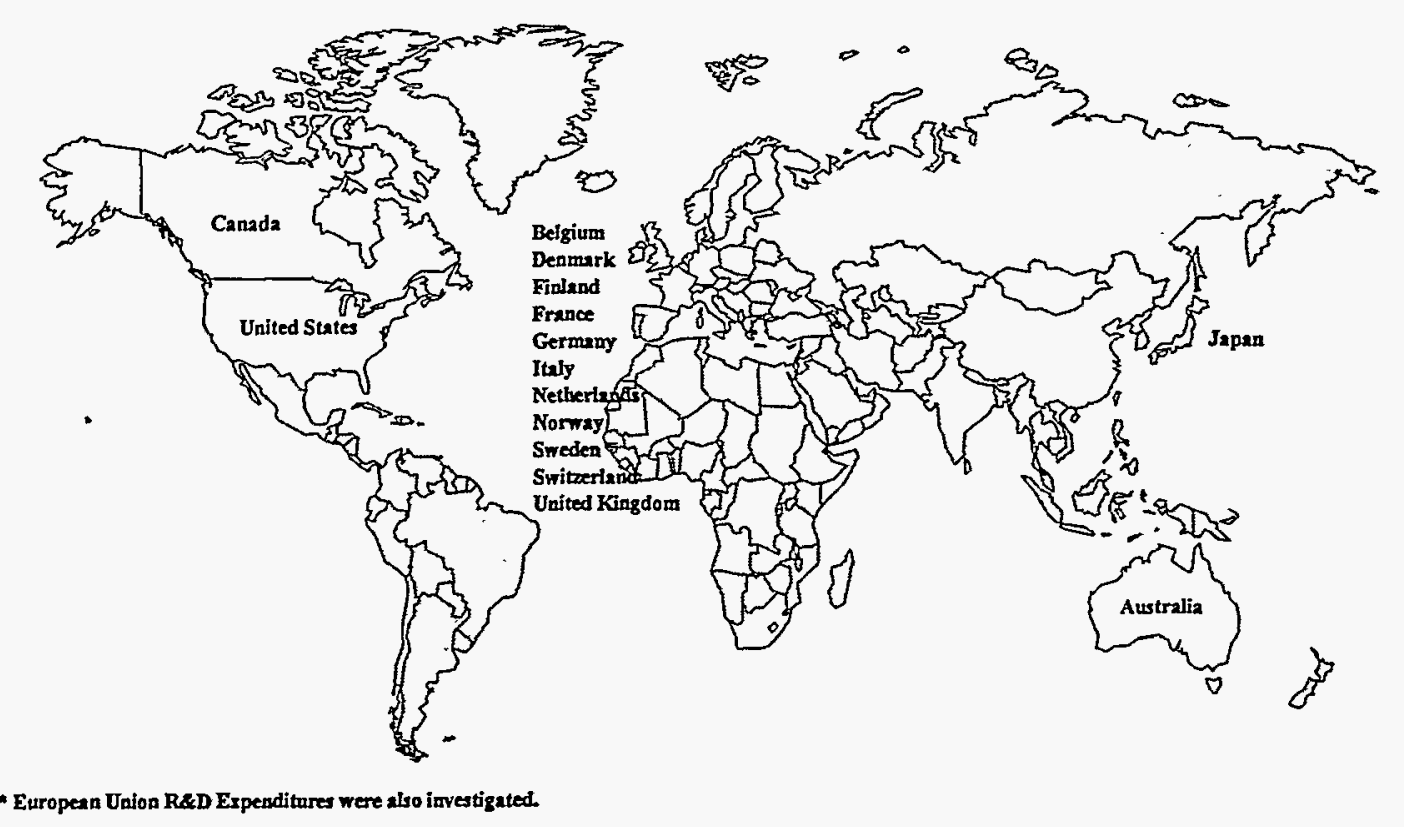

Figure 4.1. Selected Countries 


\subsection{Australia}

In Australia, R\&D as a percentage of GDP is minimal compared to the U.S. and other industrialized countries (See Figure 4.2). Fossil fuels play a central role in generating electricity, and the predominant fuel source is coal. The government is encouraging industrial support of $R \& D$ and $R \& D$ of coal technologies. A SOFC program was recently started. Current environmental legislation, fossil fuel dependence, large levels of fossil fuel reserves, and government interest in fuel cells make future funding likely. Advanced gas turbine $R \& D$ is negligible in Australia.

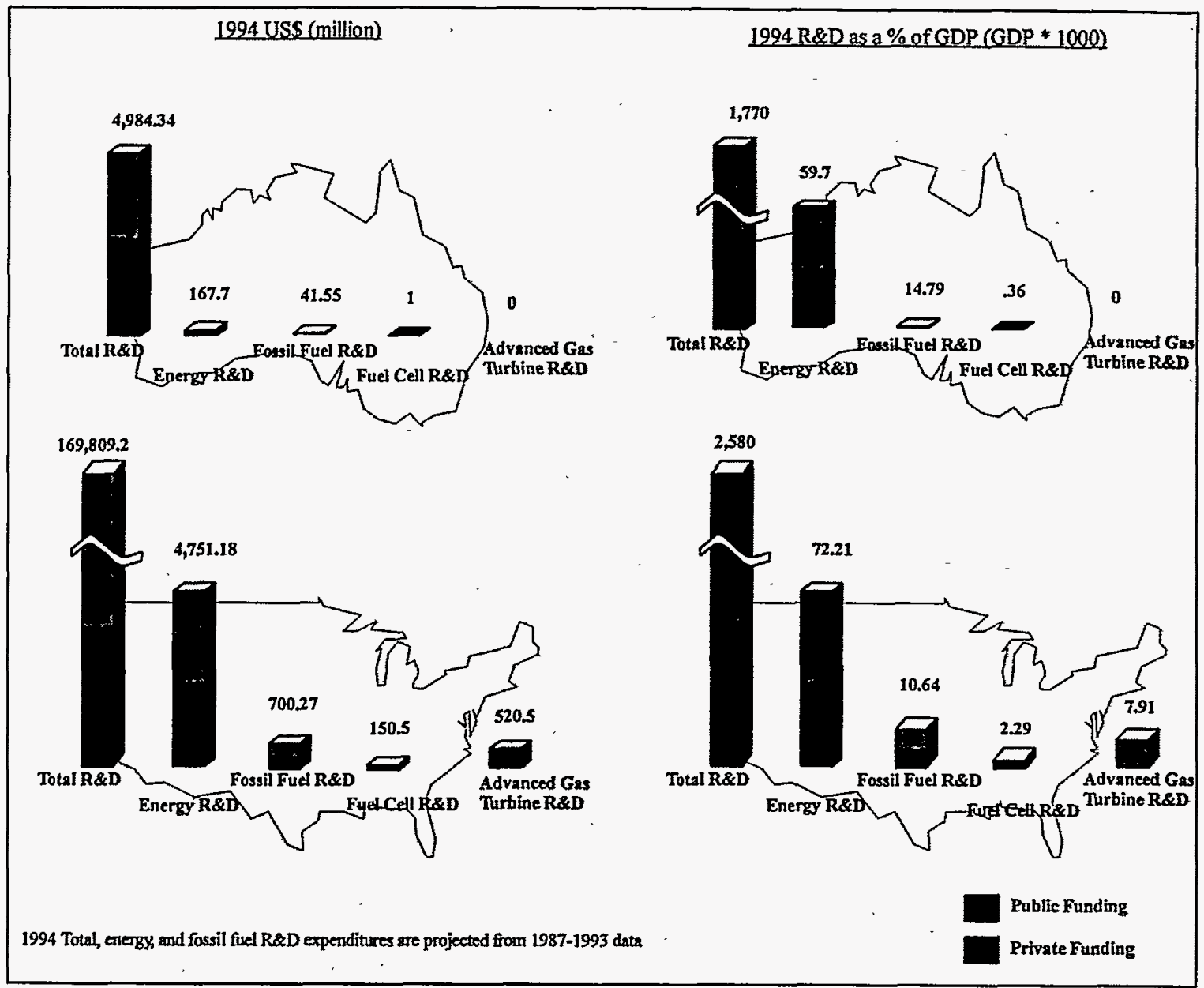

Figure 4.2. Australian R\&D Expenditures

\subsubsection{R\&D Expenditures}

Levels of research and development expenditures in Australia are considerably lower than in the U.S. Australia allocated approximately US\$5 billion on R\&D in 1994. Australia had a 
total R\&D budget as a percentage of GDP (1.8\%) which was below the average of the selected countries (2.4\%). 1994 total R\&D expenditures were based on the average annual rate of change in R\&D funding of 7.7\% (1986-1988). 1994 U.S. expenditures were based on the average annual rate of change of $4.1 \%(1988-1992)$. The funding for Australian $R \& D$ is divided about equally between public and private sources. Public sources accounted for $53.4 \%$ and private sources $46.4 \%$ of the total R\&D funding in 1994 .

Australia allocated US $\$ 168$ million to energy R\&D in 1994 . Australia accounted for $0.4 \%$ of the total energy R\&D throughout the selected countries. Energy R\&D in Australia was $3.4 \%$ of the total R\&D expenditures, compared to the U.S. value of $2.8 \%$ and the selected country average of $5.5 \%$. Australian energy R\&D as a percentage of GDP was $59.7 \%$ (GDP $* 1,000)$ compared to the U.S. figure of $72.2 \%$ and the average of selected countries $(148.3 \%)$.

Fossil-fuel plays a significant role in the overall energy $R \& D$ program of Australia. A large level of fossil fuel reserves and a high current reliance on fossil fuel electricity drives the country's R\&D funding levels. Australia generates approximately $90 \%$ of its total electricity consumption from fossil fuel technologies, and allocated close to US\$42 million to fossil fuel R\&D in 1994.

Fuel cell expenditures in Australia were minimal. A SOFC program was recently begun by the Australian government with an estimated funding level of US\$1 million. Advanced gas turbine R\&D was not supported by the Australian government at the time of this report; it was determined that any private contributions to advanced gas turbine $R \& D$ were negligible.

\subsubsection{R\&D Organizational Structure}

The organizational structure of Australian R\&D was not available.

\subsubsection{Energy R\&D and Sources of Electricity Generation}

Australia is a major energy exporter. Coal exports in 1991/1992 totaled 80.3 Mtoe (metric tons of equivalent), $67 \%$ of total Australian coal production. Coal is by far the most important energy commodity in Australia. Due to the high level of coal export, the Government of Australia has placed a high priority on coal technology R\&D, especially improving the efficiency of coal production and transport. A separate goal of the Government has been to increase the level of industrial involvement in R\&D. Therefore, the primary area of energy R\&D was determined as coal mining, preparation, and transport, with an emphasis on technologies that will significantly enhance the economic competitiveness of Australian industries. 
The industry-based Australian Coal Research Programme (ACARP) represents a result of the Government's long-term goal of increasing private industry support for R\&D. ACARP was established in 1993 to replace a similar Government-administered program. ACARP focused all of its coal R\&D funding in 1992/1993 on open-cut mining, coal preparation, coal utilization, or underground mining.

Figure 4.3. Breakdown of Australian Energy R\&D and Electricity Generation

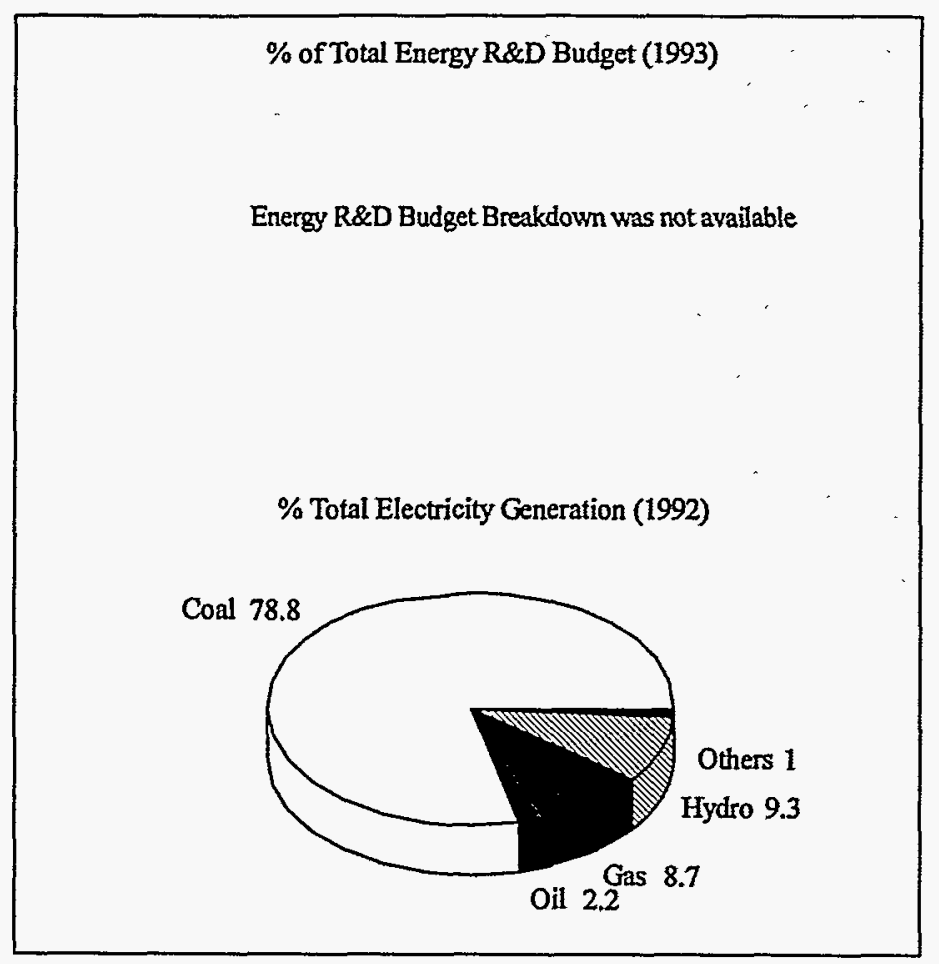

The Energy R\&D Corporation (ERDC) administers non-coal R\&D for the Government and has focused on technology awareness. A major objective under the technology awareness umbrella included linking Australia to significant overseas databases and providing local access. This objective was partially realized through Australia gaining access to the Energy Technology Data Exchange of the IEA.

Australia relies on fossil fuel to generate close to $90 \%$ of its total electrical consumption annually. Coal is used as the primary fuel source for electricity generation. Figure 4.3 indicates the percentage of total electricity generation by fuel source. Hydro represents the

only other significant electric generation method in Australia, with a share of $9.3 \%$. The IEA estimated that fossil fuel shares would increase to $92.6 \%$ by the year 2005 and that the Hydro share would shrink to $7.8 \%$ of total electricity generation.

\subsubsection{Fuel Cell and Advanced Gas Turbine Projects}

Tables 4.1 and 4.2 indicate the fuel cell and advanced gas turbine projects identified in Australia. Total fuel cell R\&D funding was estimated at US $\$ 1$ million in 1994. A SOFC program was recently begun by the Australian Government. Any privately-funded fuel cell programs were considered negligible.

Australia is researching the use of fuel cells on its "Collins" class submarine. The fuel cell stacks allow the submarine to stay submerged longer and lower the risk of radar detection. The Defense Science and Technology Organization signed a contract to buy a $5 \mathrm{~kW}$ fuel-cell 
power supply system from EP Fuel Cells (U.S.) in 1993. Australian researchers planned to evaluate the commercial system and build single fuel cells for extensive laboratory testing.

Two national strategies developed in 1992 provide the focus of Australian energy policy, the National Strategy for Ecologically Sustainable Development (ESD) and the National Greenhouse Response Strategy (NGRS). These two strategies were endorsed by the heads of federal and state governments throughout Australia. In light of the recent increase in environmental awareness made apparent by these two strategies, heavy dependence on fossil fuels for electricity generation and the recent creation of a SOFC program it is likely that fuel cells will continue to receive funding in the future.

Table 4.1. Fuel Cell Project List for Australia

\begin{tabular}{|l|l|l|l|l|}
\hline Project & $\begin{array}{l}\text { Funding } \\
\text { Source }\end{array}$ & Performer & Dates & $\begin{array}{l}\text { Funding } \\
\text { Level }\end{array}$ \\
\hline $\begin{array}{l}\text { SOFC } \\
\text { Development and } \\
\text { Commercial } \\
\text { (Collins } \\
\text { Submarine) }\end{array}$ & $\begin{array}{l}\text { Federal } \\
\text { Government }\end{array}$ & Various & NA & 1 million \\
US\$*
\end{tabular}

* Estimated funding level; actual data not available.

Advanced gas turbine R\&D was not supported by the Government throughout 1994. There are no major gas turbine manufacturing companies located in Australia, and the private contribution to advanced gas turbine R\&D was negligible in 1994. Analysis of spending trends was not possible because of paucity of data.

Table 4.2. Advanced Gas Turbine Project List for Australia

\begin{tabular}{|l|l|l|l|l|}
\hline Project & $\begin{array}{l}\text { Funding } \\
\text { Source }\end{array}$ & Performer & Dates & Funding Level \\
\hline None & $\begin{array}{l}\text { Federal } \\
\text { Government }\end{array}$ & NA & NA & None \\
\hline
\end{tabular}




\subsection{Belgium}

Belgium is a nuclear energy intensive country that does not have a large overall R\&D program. The country uses nuclear technology to generate more than $60 \%$ of its total electricity. In contrast, the energy R\&D budget of Belgium focuses on the R\&D within the coal sector. As a result, Belgium has relatively high levels of coal $R \& D$ as a percentage of GDP. ELENCO, a private Belgian company, has supported an alkaline fuel-cell development program since the mid 1970s. Advanced gas turbine R\&D is negligible in Belgium.

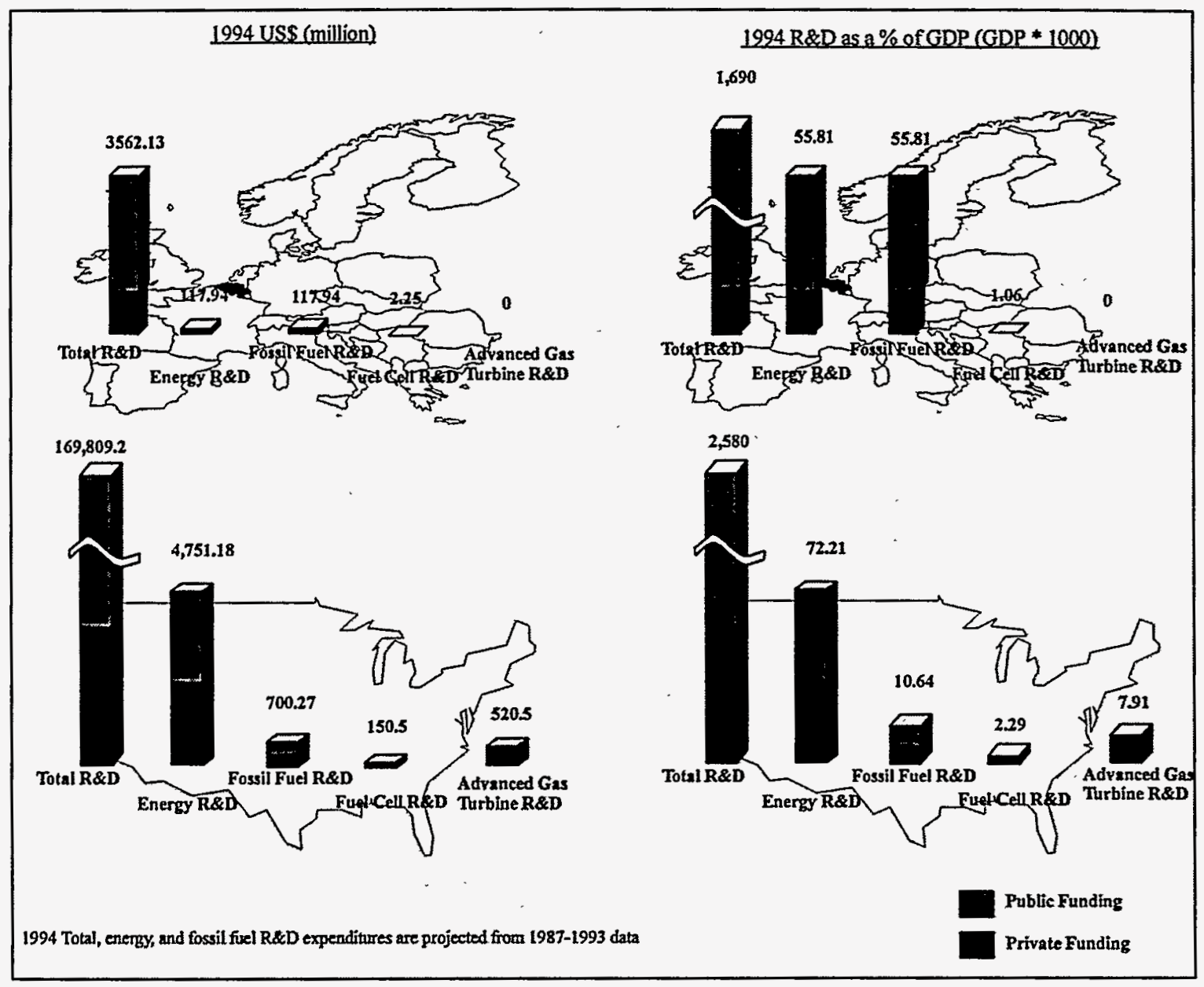

Figure 4.4. Belgian R\&D Expenditures

\subsubsection{R\&D Expenditures}


R\&D expenditures in Belgium totaled US $\$ 3.6$ billion in 1994 (See Figure 4.4). Belgium accounted for $0.7 \%$ of the total R\&D expenditures throughout the selected countries and had the second lowest level of R\&D expenditures as a percentage of GDP in $1994(1.69 \%)$. The average for all selected countries was $2.4 \%$ and $2.58 \%$ for the U.S. 1994 R\&D expenditures were based on the average annual rate of change in total R\&D funding of $5.7 \%$ (1986-1990). This level was higher than the annual rate of 4.1\% (1988-1992) used to estimate 1994 expenditures in the U.S.. Belgium relies heavily on private funding sources for R\&D programs ( $73 \%$ of the total funding is from private sources).

Norway is the only selected country with an energy R\&D budget less than that of Belgium. Belgium has decreased the level of funding for its energy R\&D program the most rapidly of any of the selected countries, an average annual rate of $-15.8 \%$ (1986-1992). The Government of Belgium reduced its allocations for energy R\&D from a 1986 level of about US\$107 million to an estimated 1994 level of approximately US\$32 million.

Fossil fuel was considered the only area of energy R\&D being funded in Belgium in 1994. Coal combustion was the focal area within the fossil fuel R\&D budget. It was determined that Belgian expenditures for fossil fuel R\&D would be US $\$ 117.9$ million, $3.31 \%$ of the country's total R\&D expenditures. Of the selected countries, Belgium had the highest level of fossil fuel $R \& D$ expenditures as a percentage of total $R \& D$ expenditures and as a percentage of GDP. The fossil fuel R\&D budget of the Government increased at an annual rate of $40.9 \%$ from 1988 to 1993 . The expenditures increased from US $\$ 4.4$ million to US\$24.4 million over this time period.

Fuel cell R\&D funding is estimated at approximately US\$2.25 million a year in Belgium. The country's fuel cell program is supported entirely by private sources (ELENCO) and focuse on the development of PEFC for automotive applications. Belgium expenditures on advanced gas turbine $\mathrm{R} \& \mathrm{D}$ were determined as negligible.

\subsubsection{R\&D Organizational Structure}

R\&D structure in Belgium was not available. 


\subsubsection{Energy R\&D and Sources of Electricity}

Most Government-funded R\&D in Belgium was for coal. In contrast, oil and gas did not receive any energy $R \& D$ funding in 1993 (See Figure 4.5). Conservation, especially transport, received the second highest level of energy R\&D funding in Belgium in 1993. Solar, energy systems analysis/others, and electricity received small levels of energy R\&D funding. Nuclear R\&D funding information was not available; however, Belgium allocated US\$64 million in 1988 and US\$45 million in 1989 to nuclear technologies. Belgium used nuclear technology to generate $61 \%$ of its electricity in 1992 . Coal was used for an additional $26 \%$. Future projections

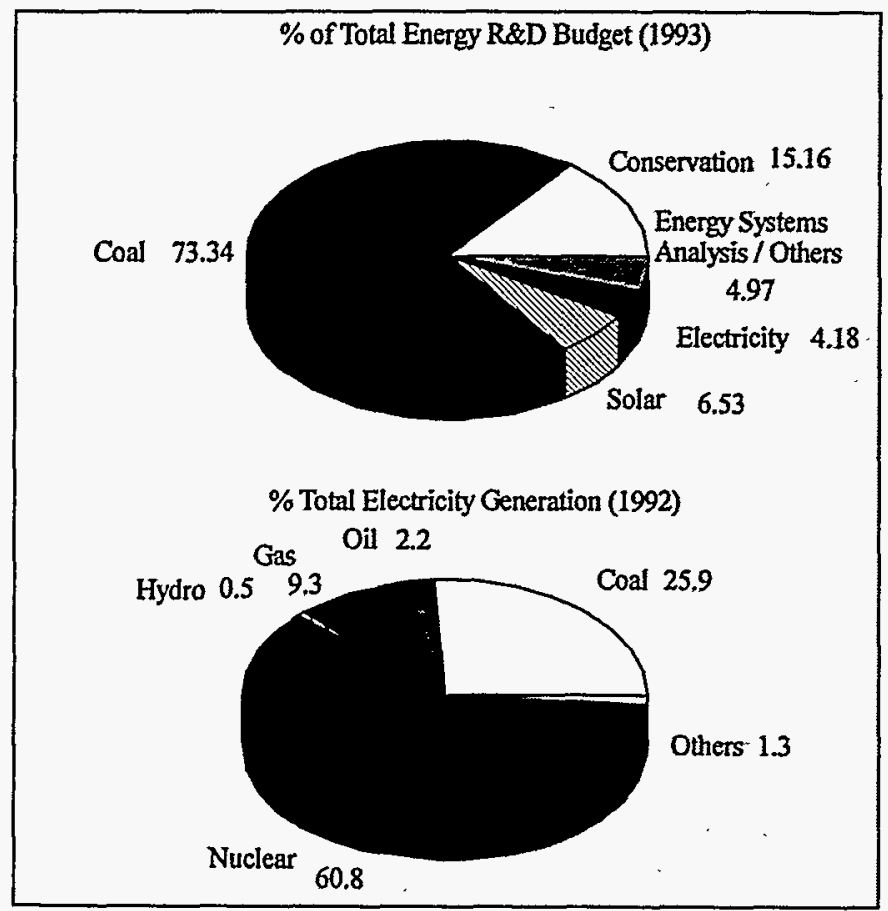

Figure 4.5. Belgian Energy R\&D and Electricity Generation indicate that the use of gas will increase at an average annual rate of $5-8 \%$ over the next five years. In the year 2010, gas will account for $28 \%$ of the total electricity generation while coal and nuclear will reduce to 24 and $47 \%$, respectively.

\subsubsection{Fuel Cell and Advanced Gas Turbine Projects}

Tables 4.3 and 4.4 indicate the fuel cell and advanced gas turbine projects currently funded by Belgian sources. Currently, one such project is confirmed. The ELENCO AFC for Transportation Applications Project has been active since the mid 1970s and continues funding. ELENCO funded the project at a level of

US\$18 million from 1976 through 1984. In 1991, ELENCO began development of a 56passenger bus powered by a $200 \mathrm{~kW}$ battery/AFC hybrid system. The bus was developed in conjunction with Air Products (Dutch), SAFT (France), and Ansaldo (Italy) within the European industrial collaboration framework of the EUREKA program. A separate project investigating polymer electrolyte fuel cell electrode development funded and performed by VITO, the Flemish Institute for Technological Research, was completed in 1993.

ELENCO has maintained a long tradition of R\&D toward fuel cells for transport applications. The ELENCO bus was expected to become operable in Brussels in 1994 as a technical demonstration. ELENCO has developed plans to deploy several prototype buses, to be produced in 1995, to cities throughout the world. The high level of activity by ELENCO 
and the current interest by VITO indicates that funding for fuel-cell R\&D activities will continue over the next several years.

Table 4.3. Fuel Cell Project List for Belgium

\begin{tabular}{|l|l|l|l|l|}
\hline Project & $\begin{array}{l}\text { Funding } \\
\text { Source }\end{array}$ & Performer & Dates & Funding Level \\
\hline $\begin{array}{l}\text { PEFC } \\
\text { Electrode } \\
\text { Development }\end{array}$ & VITO & VITO & Prior to 1993 & NA \\
\hline AFC & & ELENCO & $1976-1984$ & (US\$18 million) \\
Research & ELENCO & 1984-present & (1976-1984) \\
Stack & & & & \\
Development & & & & \\
Bus Demo. & & & & \\
\hline
\end{tabular}

Advanced gas turbine R\&D was not supported by the Government throughout 1994. There are no major gas turbine manufacturing companies located in Belgium; therefore, private contribution was assumed negligible in 1994.

Table 4.4. Advanced Gas Turbine Project List for Belgium

\begin{tabular}{|l|l|l|l|l|}
\hline Project & $\begin{array}{l}\text { Funding } \\
\text { Source }\end{array}$ & Performer & Dates & Funding Level \\
\hline None & $\begin{array}{l}\text { Federal } \\
\text { Government }\end{array}$ & NA & NA & None \\
\hline
\end{tabular}




\subsection{Canada}

Canada is an energy $R \& D$ intensive country. Its energy $R \& D$ expenditures as a percentage of GDP are among the highest of the selected countries. Canada spends most of its energy $\mathrm{R} \& \mathrm{D}$ budget on fossil fuel or nuclear fission activities and projects. The private sector supplies roughly $73 \%$ of the country's energy R\&D funding. The Canadian company Ballard Power Systems, in cooperation with Daimler Benz of Germany, has a large fuel cell R\&D program concentrating on development of PEFC technology for automotive applications. Advanced gas turbine R\&D is supported by the National Research Council of Canada.

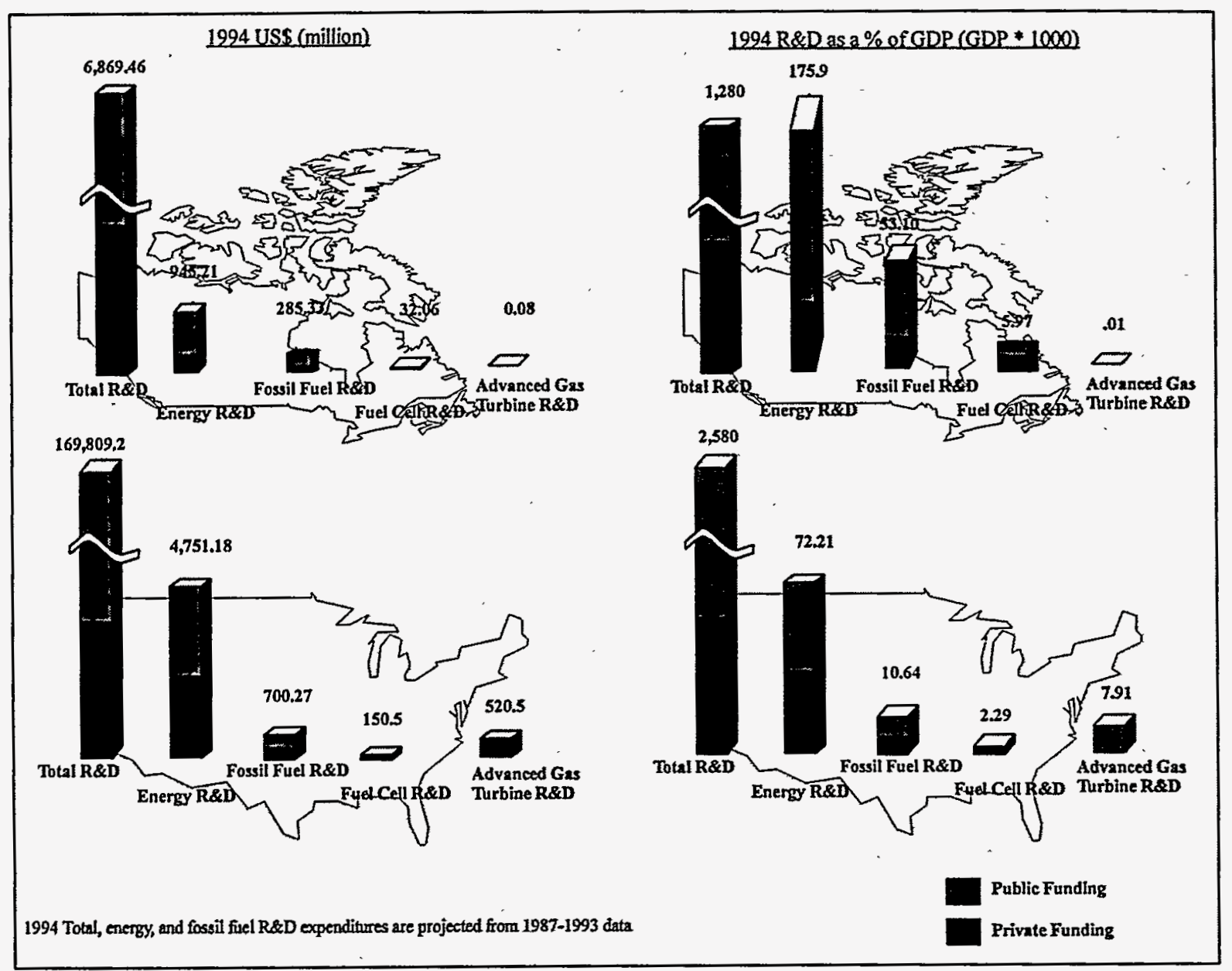

Figure 4.6. Canadian R\&D Expenditures 


\subsubsection{R\&D Expenditures}

Overall, Canadian R\&D expenditures as a percentage of GDP were the lowest of the selected countries. In 1994, Canada had an estimated total R\&D budget of US\$6,869 million (See Figure 4.6). In that year, Canadian funding accounted for $1.4 \%$ of the total $R \& D$ expenditures of the selected countries. Within the relatively small overall $R \& D$ program, energy $R \& D$ was a priority in Canada. The Canadian energy $R \& D$ budget accounted for close to $14 \%$ of its total R\&D budget compared to $2.8 \%$ in U.S. The Canadian energy R\&D budget as a percentage of total R\&D is higher than that of all other selected countries except Japan. The Canadian fossil fuel budget accounts for close to $30 \%$ of the total energy R\&D budget and $4.2 \%$ of the total R\&D budget. The Canadian fossil fuel R\&D budget of US $\$ 285$ million is the third largest of the selected countries and the fossil fuel R\&D as a percentage of total $R \& D$ is the largest of the selected countries. Canada maintains a high level of fuel cell R\&D funding. The country was estimated to fund fuel cell R\&D at approximately US $\$ 32$ million a year in 1994. This is the fourth highest level of fuel cell R\&D of the selected countries. Fuel cell R\&D as a percentage of total R\&D in Canada was estimated at $0.47 \%$, the highest of the selected countries. Ballard Power Systems was responsible for $98 \%$ of the total fuel cell R\&D funding in Canada. Ballard has estimated it will need to spend US\$125 million over the next four years on its fuel cell program. Canadian advanced gas turbine R\&D was minimal in 1994. Approximately, US\$80,000 was provided for advanced gas turbine $R \& D$, the lowest of the countries reporting funding.

\subsubsection{R\&D Organizational Structure}

R\&D in Canada is supported by the following primary sectors:

- Industrial . Oil companies, gas companies, and utilities

- Federal Government. Atomic Energy Canada Limited and A Base

- Panel on Energy R\&D (PERD). PERD manages the federal program on energy R\&D; supplies energy R\&D funding to all federal departments, including atomic energy, national defense, environment, health, and natural resources

- Provincial governments

\subsubsection{Energy $R \& D$ and Sources of Electricity}

The Government has divided its energy R\&D program into six tasks: (1) energy efficiency; (2) coal; (3) fusion; (4) renewable energy and generic environment; (5) alternative transportation fuels; and (6) oil, gas, and electricity. Canada splits the majority of its R\&D budget between nuclear fission and fossil fuel activities (see Figure 4.7). Nuclear R\&D activities accounted for $45 \%$ and fossil fuel R\&D $30 \%$ of the total energy R\&D budget in 1993. Nuclear fission activities are centered on converter reactors, nuclear fuel cycle, and 
nuclear supporting technologies. Fossil fuel activities are focused on oil and gas R\&D, with smaller resources allocated to coal projects.

Canada has high levels of fossil fuel reserves. The high level of R\&D expenditures in oil and gas activities are concerned with three primary areas: (1) geoscience; (2) environment; and (3) transportation. Geoscience activities focus on reservoir evaluation, onshore geotechnics, offshore geotechnics, ice/structure interation, structural engineering, materials, and personnel safety. Environment activities include forecasting, design, and environmental impact investigations. Transportation issues are pipeline permafrost interation, pipeline engineering, hydrographic technologies and charting, and marine shipping.

The nuclear fission R\&D program is not highlighted by the Government; therefore, it is believed that the majority of fission $R \& D$ comes from private sources. The Government allocates major funding for its nuclear fusion program. The Canadian fusion energy program consists of two main programs: Tokamak de Varennes and the Canadian Fusion Fuels Project.

Hydroelectric power plants were used to produce $61 \%$ of the total electricity in Canada in 1992. Coal was the second leading fuel source, with a percentage of total electricity generated at $17.5 \%$. Oil, gas, and nuclear were used to generate $21 \%$ of the total electricity in Canada. Current sources of electricity are not the primary driving force behind energy R\&D.

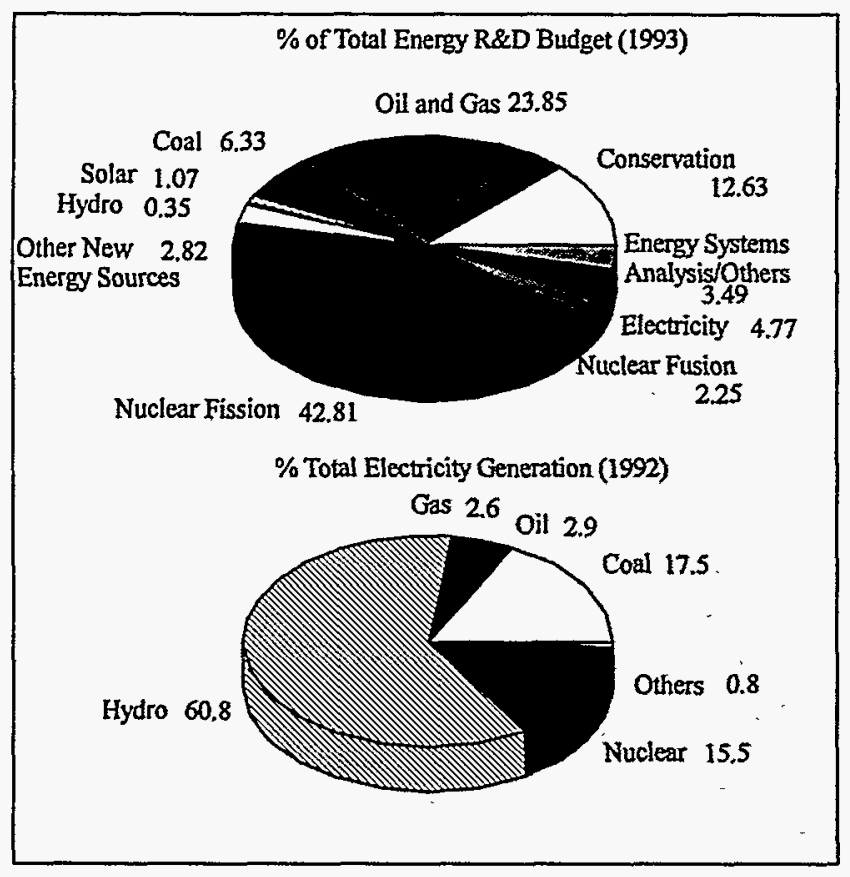

Figure 4.7. Breakdown of Canadian Energy R\&D and Electricity Generation

\subsubsection{Fuel Cell and Advanced Gas Turbine Projects}

Three active fuel cell projects are being funded (see Table 4.5). Their total funding is approximately US\$32 million. The largest program is being funded and performed by Ballard Power Systems. Ballard plans to spend US\$125 million from 1994 to 1997 on the development of polymer electrolyte fuel cells. Ballard's program is in cooperation with Daimler Benz of Germany and focuses on placing proton exchange membrane fuel cells on the commercial market. The Government of Canada supported three fuel cell projects in 1994, with funding levels of US $\$ 240,000, U S \$ 182,000$, and US $\$ 200,000$ under the country's

Alternative Transportation Fuels task. The Canadian Electrical Association, through BC Hydro and Ontario Hydro, has supported three fuel cell projects over the past three years. BC Hydro has allocated US\$120,000 during 1993-1995 for fuel cell R\&D. Ontario Hydro 
has supported two demonstration projects, a $200 \mathrm{~kW}$ PAFC project funded at US $\$ 250,000$ over three years and a Westinghouse supplied SOFC stack demonstration funded at US $\$ 200,000$ over three years.

Table 4.5. Fuel Cell Project List for Canada

\begin{tabular}{|l|l|l|l|l|}
\hline Project & $\begin{array}{l}\text { Funding } \\
\text { Source }\end{array}$ & Performer & Dates & $\begin{array}{l}\text { Funding Level } \\
\text { (U.S.S (million) }\end{array}$ \\
\hline $\begin{array}{l}\text { Alternative } \\
\text { Transportation } \\
\text { Fuels (3 } \\
\text { projects) }\end{array}$ & $\begin{array}{l}\text { Federal } \\
\text { Government }\end{array}$ & Various & 1994 & .622 \\
\hline $\begin{array}{l}\text { PEFC } \\
\text { Development }\end{array}$ & $\begin{array}{l}\text { Ballard Power } \\
\text { Systems } \\
\text { (Daimler Benz) }\end{array}$ & $\begin{array}{l}\text { Ballard Power } \\
\text { Systems }\end{array}$ & $1994-1997$ & 125.0 \\
\hline $\begin{array}{l}\text { 200 KW } \\
\text { Demonstration }\end{array}$ & $\begin{array}{l}\text { Canadian } \\
\text { Electrical } \\
\text { Westinghouse } \\
\text { S.O.F.C. }\end{array}$ & $\begin{array}{l}\text { BC Hydro } \\
\text { (Power Tech) } \\
\text { Ontario Hydro }\end{array}$ & $1993-1995$ & .250 \\
\hline
\end{tabular}

Advanced gas turbine R\&D funding is minimal. The Canadian Electric Association has supplied funding for a Pacific Gas and Electric (U.S.) / EPRI (U.S.) advanced gas turbine project at a level of approximately US $\$ 325,000$ over four years (see Table 4.6). United Technologies, Rolls Royce, and General Electric have facilities located in Canada; however, due to their foreign ownership, any R\&D funded by these companies was attributed to their home countries.

Government support for advanced gas turbine R\&D is provided by Canada's National Research Council through the Institute for Aerospace Research and the Institute for Mechanical Engineering. The Institute for Aerospace Research has focused on development of coatings for compressor and hot section parts, studies involving thermal fatigue, the response of alloy Inconel 718 to heat treatments designed to produce serrated grain boundaries and the determination of fatigue crack initiation and crack growth rates in turbine disc materials. The Institute for Mechanical Engineering has performed the following work relevant to gas turbines: propulsion systems condition monitoring, experimental performance assessment techniques, aeropropulsion studies, advanced aerodynamic studies, compressor aerodynamics research, machinery condition monitoring, continuous combustion processes, internal aerodynamics and heat transfer, and computational fluid dynamics and 
thermodynamics. Funding levels for advanced gas turbine R\&D by the National Research Council were unavailable.

Table 4.6. Advanced Gas Turbine Project List for Canada

\begin{tabular}{|l|l|l|l|l|}
\hline Project & $\begin{array}{l}\text { Funding } \\
\text { Source }\end{array}$ & Performer & Dates & Funding Level \\
\hline None & $\begin{array}{l}\text { Federal } \\
\text { Government }\end{array}$ & NA & NA & NA \\
\hline Various & $\begin{array}{l}\text { Canadian } \\
\text { Electrical } \\
\text { Association }\end{array}$ & PGE/EPRI & $1993-1996$ & $\$ 325,000$ \\
\hline
\end{tabular}




\subsection{Denmark}

Denmark has rapidly increased funding for its energy and fossil fuel R\&D programs.

Although the overall R\&D program in Denmark is not relatively large, at the average rate of change in funding, the program will develop rapidly but will not be comparable with such large European programs as Germany, France, Italy, and the UK. The fuel cell program in Denmark is well developed and receives much interest. As a percentage of GDP, fuel cell expenditures in Denmark were the highest of the selected countries. Advanced gas turbine R\&D expenditures were negligible.

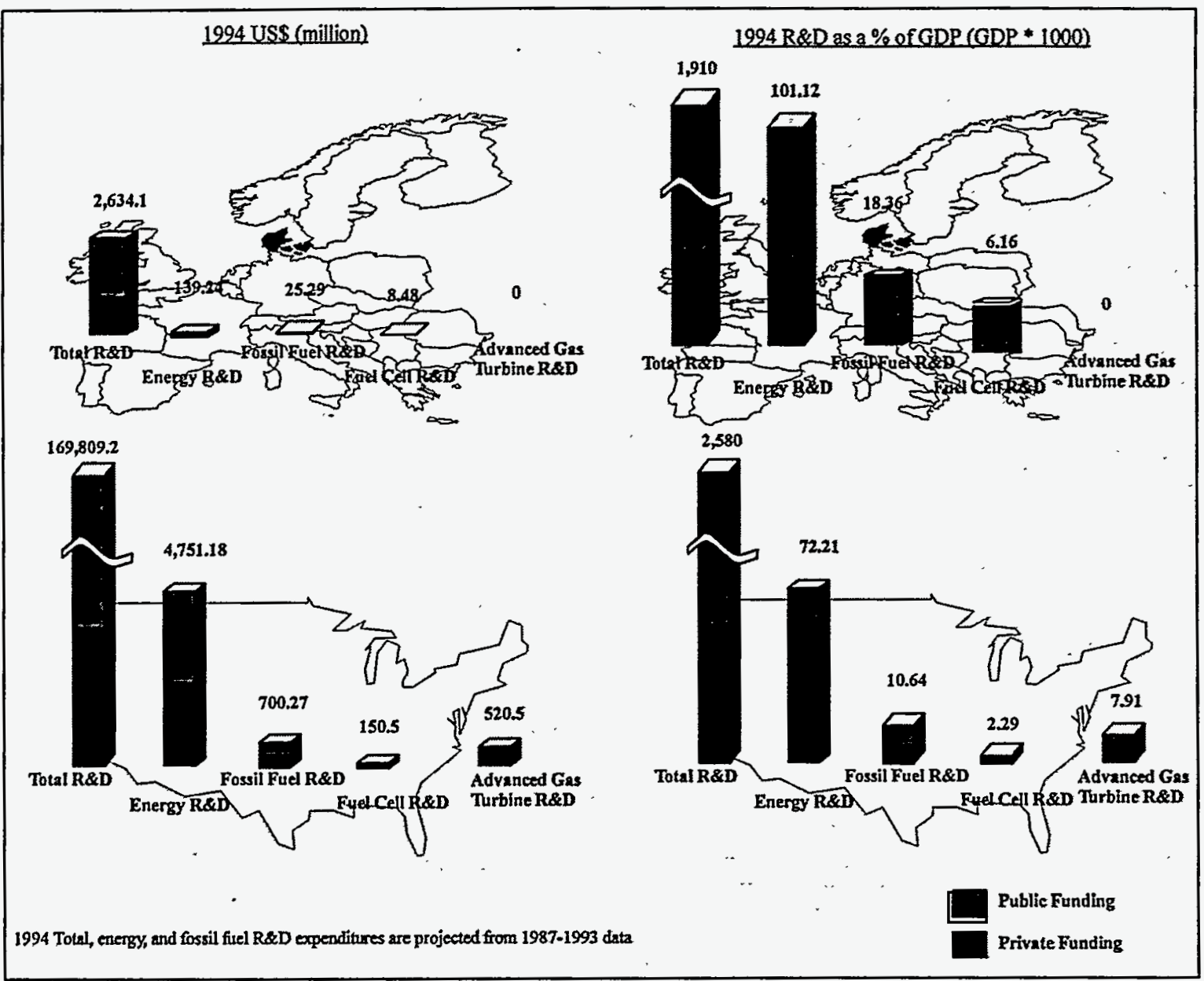

Figure 4.8. Danish R\&D Expenditures

\subsubsection{R\&D Expenditures}

Denmark does not have a large level of resources devoted to R\&D. The country allocated US $\$ 2.63$ billion in 1994, the second lowest of the selected countries. Denmark allocated 
$1.91 \%$ of GDP to R\&D in 1994 (see Figure 4.8). That level was considerably lower than that of the U.S. (2.58\%) and the selected country average (2.41\%). Danish energy R\&D, at $5.3 \%$ of total R\&D, received a lower than average (6.1\%) but higher than the U.S. (2.8\%) level of priority in 1994. Denmark allocated $101 \%$ of GDP (GDP *1,000) towards energy R\&D in 1994 (see Figure 4.8). 1994 energy R\&D expenditures were estimated based on the average annual rate of change in energy R\&D of $14.1 \%$ in Denmark (1987-1993). This rate was the highest of the selected countries. Due to the low level of present energy R\&D funding, it is unlikely that Danish energy R\&D budgets will increase to sizes competitive with any of the larger European nations or with the U.S.. Danish fossil fuel R\&D totaled approximately US\$25.3 million in 1994. 1994 fossil fuel expenditures were based on the average annual percentage change in fossil fuel R\&D of $25 \%$ (1987-1993) in Denmark. The average percentage change in fossil fuel R\&D for all of the selected countries was - $4 \%$ and $-22.7 \%$ (1990-1993) for the U.S.. Danish fuel cell R\&D expenditures totaled US\$8.5 million in 1994. Danish fuel cell expenditures as a ercentage of GDP totaled $6.2 \%$ in 1994, the highest of the selected countries. The private sector provided $95 \%$ of Danish fuel cell R\&D funding. Danish advanced gas turbine R\&D funding was negligible in 1994.

\subsubsection{R\&D Organizational Structure}

The Danish Ministry of Energy is responsible for all government-funded energy R\&D. The Riso Research Center, the largest Government research center in Denmark funds most of these R\&D activities. Riso has a staff of approximately 1,000 . About $60 \%$ of Riso's funding comes directly from the Government, with the balance coming from Danish and foreign clients. Riso concentrates on encouraging privately-funded R\&D in areas consistent with the Government research priorities.

\subsubsection{Energy R\&D and Sources of Electricity}

Danish energy policy has been increasingly influenced by environmental considerations over the past several years. The Danish energy policy Energy 2000 focuses on reducing $\mathrm{CO}_{2}$, $\mathrm{SO}_{\mathrm{x}}$, and $\mathrm{NO}_{\mathrm{x}}$ emissions by the year 2005 while maintaining a reliable, efficient, and economic supply of energy.

A review of the progress of the Energy 2000 plan performed by the Ministry of Energy concluded that the existing measures would not be sufficient to meet the goals outlined in the Energy 2000 plan. Subsequently, the Danish parliament passed three laws: Energy Efficiency Standards, Amendments to the Electricity Supply Act, and Changes to the Heat Supply Act. All three aimed at reaching the goal of Energy 2000. In addition, the Danish parliament instructed the electric utilities to increase their use of biomass and wood for power generation. The Danish R\&D program has adopted a number of priority areas that reflect the overall Danish energy policy. Denmark is focusing its energy R\&D in the following areas (IEA 1993):

- Electricity-savings products and processes

- Reduction of heat consumption in buildings 
- Biomass

- Wind power

- Efficient and environmentally- begin electricity production

- District heating

- Enhanced oil and gas production

- New products and methods that can decisively reduce problems related to energy production, distribution, consumption, and storage

- Increased understanding of the relations between the energy sector and society as a basis for improved energy policymaking.

Denmark allocated 33\% of its energy R\&D budget to Other New Energy Sources in 1993 (see Figure 4.9 ). Wind (14.9\%), ocean (1.3\%), and biomass (17.2\%) comprise this category. Conservation, electricity, and coal each received more than $10 \%$ of the total energy R\&D budget in 1993. The energy R\&D budget reflects the Danish energy policy to integrate environmental and energy considerations. Although coal is the primary fuel for generating electricity, it only received $11 \%$ of the energy R\&D budget. Environmentally-friendly, electrical generation technologies, such as wind, ocean, solar, and biomass received much higher levels of R\&D funding. Nuclear technologies received less than $4.5 \%$ of funding.

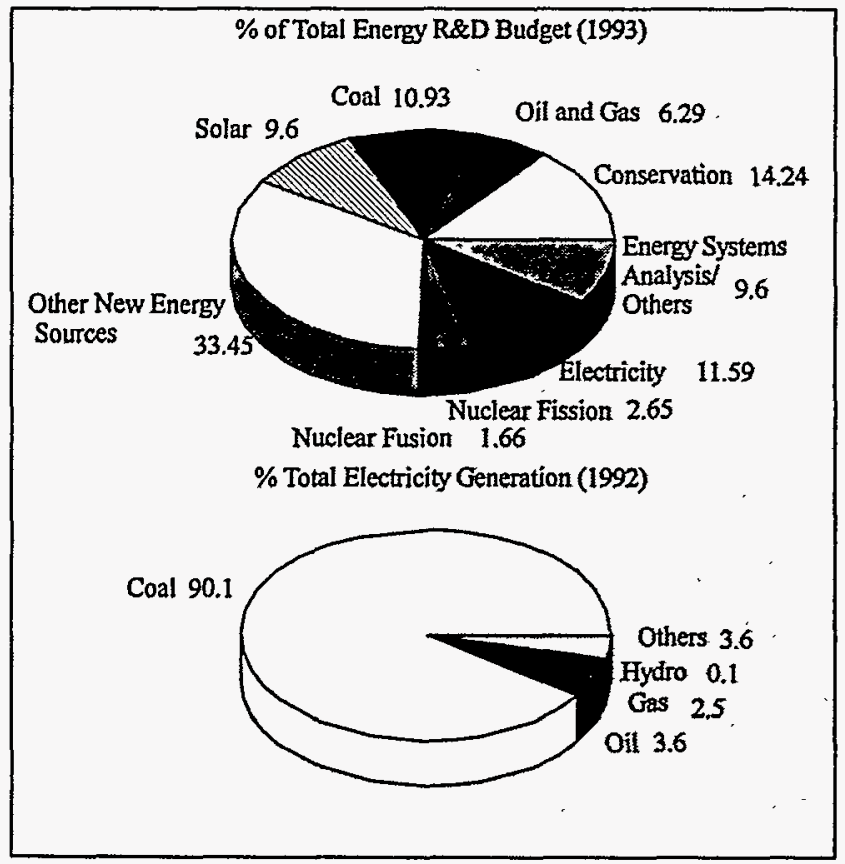

Figure 4.9. Breakdown of Danish Energy R\&Dand Electricity Generation
In 1992, the primary source of electricity generation in Denmark was coal (90\%). Fossil fuels were used to produce $96 \%$ of the country's total electricity. Future projections indicate that coal use will gradually be replaced by gas and other solid fuels. In 2010, gas is projected to account for $36 \%$ of the total electricity generated.

\subsubsection{Fuel Cell and Advanced Gas Turbine Projects}

Table 4.7 indicates fuel cell projects and funding levels for Denmark. This country has one of the largest fuel cell programs in Europe, the total funding of which was estimated at US\$8.5 million/yr. Elsam, Elkraft, Haldor Topsoe, and Innovision are the leading funders of fuel cell $R \& D$ in Denmark. R\&D on SOFC, PAFC, PEFC, MCFC, and DMFC is being performed in Denmark. Elsam is concentrating its R\&D efforts on the development of SOFC. Elsam provides funding for a project that includes the Danish Energy Agency and Haldor Topsoe. Elkraft is involved in a large MCFC project with Haldor Topsoe, and the German companies Daimler Benz and Ruhrgas. Haldor Topsoe is involved in four projects: $50 \%$ EU-funded PEFC project with KFA Julich (Germany), an in-house funded PAFC project, the SOFC 
Elsam project, and the MCFC Elkraft project. Innovision is involved in a DMFC project with Siemens (Germany) that is $50 \%$ funded by the EU. Riso Research Center is performing the research for separate SOFC R\&D projects funded by the EU and by British Gas.

Table 4.7. Fuel Cell Project List for Denmark

\begin{tabular}{|c|c|c|c|c|}
\hline Project & $\begin{array}{l}\text { Funding } \\
\text { Source }\end{array}$ & Performer & Dates & $\begin{array}{l}\text { Funding Level } \\
\text { USS (million) }\end{array}$ \\
\hline MCFC Asnaes & Elkraft & $\begin{array}{l}\text { Elkraft, Haldor } \\
\text { Topsoe, } \\
\text { Daimler Benz, } \\
\text { Ruhrgas }\end{array}$ & 1991-1995 & 8 \\
\hline $\begin{array}{l}\text { PAFC reformer } \\
\text { development }\end{array}$ & Haldor Topsoe & $\mathrm{NA}$ & $\overline{\mathrm{NA}}$ & $\overline{\mathrm{NA}}$ \\
\hline PAFC Jutland & Elsam & $\begin{array}{l}\text { Elsam, } \\
\text { Naturgas Syd }\end{array}$ & 1994-1996* & $0.05 / \mathrm{yr}$. \\
\hline DMFC & $\begin{array}{l}\text { Siemens, } \\
\text { Innovision, } \\
(50 \% \text { EC) }\end{array}$ & $\begin{array}{l}\text { Innovision, } \\
\text { Siemens }\end{array}$ & 1992 - Present & $\overline{N A}$ \\
\hline PEFC & $\begin{array}{l}\text { Haldor Topsoe, } \\
\text { KFA Julich, } \\
\text { (50\% EC) }\end{array}$ & $\begin{array}{l}\text { Haldor Topsoe, } \\
\text { KFA Julich }\end{array}$ & 1992 - Present & $\overline{\mathrm{NA}}$ \\
\hline SOFC & $\overline{\mathrm{EU}}$ & $\begin{array}{l}\text { Riso Research } \\
\text { Center }\end{array}$ & $1994-1996^{*}$ & 3.2 \\
\hline $\begin{array}{l}\text { SOFC stack } \\
\text { development }\end{array}$ & $\begin{array}{l}\text { British Gas } \\
\text { EU }\end{array}$ & $\begin{array}{l}\text { Riso Research } \\
\text { Center }\end{array}$ & 1993-1994 & .10 \\
\hline
\end{tabular}


Table 4.7. Continued.

\begin{tabular}{|c|c|c|c|c|}
\hline $\begin{array}{l}\text { SOFC Jutland } \\
\text { Lab Scale } \\
\text { SOFC Jutland } \\
\text { Scale-up }\end{array}$ & $\begin{array}{l}\text { ELSAM } \\
\text { Danish Energy } \\
\text { Agency } \\
\text { ELKRAFT } \\
\text { Riso } \\
\text { Innovision } \\
\text { Odense } \\
\text { University } \\
\text { Haldor Topsoe } \\
\text { Technical } \\
\text { University of } \\
\text { Denmark }\end{array}$ & $\begin{array}{l}\text { Riso Research } \\
\text { Center }\end{array}$ & $\begin{array}{l}1991-1993 \\
1993-1997\end{array}$ & $\begin{array}{l}7.6 \\
14.4 \\
4 \text { (ELSAM) } \\
4 \text { (Danish Energy } \\
\text { Agency) } \\
6.4 \text { (others) }\end{array}$ \\
\hline
\end{tabular}

* Projects were assumed to start in 1994.

Advanced gas turbine research in Denmark was funded at negligible levels in 1994 (see Table 4.8). All such activities in Denmark are demonstrations of advanced gas turbines researched and developed in other countries.

Table 4.8. Advanced Gas Turbine Project List for Denmark

\begin{tabular}{|l|l|l|l|l|}
\hline Project & $\begin{array}{l}\text { Funding } \\
\text { Source }\end{array}$ & Performer & Dates & Funding Level \\
\hline None & $\begin{array}{l}\text { Federal } \\
\text { Government }\end{array}$ & NA & NA & None \\
\hline
\end{tabular}




\subsection{Finland}

Finland had one of the smallest R\&D budgets of the selected countries; however, Finland had the largest R\&D budget when normalized by GDP. The country trailed only Japan in energy R\&D spending as a percentage of GDP. As a percentage of total R\&D, Finland had an energy R\&D budget of more than double that of the U.S. R\&D in Finland is primarily supported by private industry. Fuel cell R\&D was minimal and advanced gas turbine R\&D was negligible.

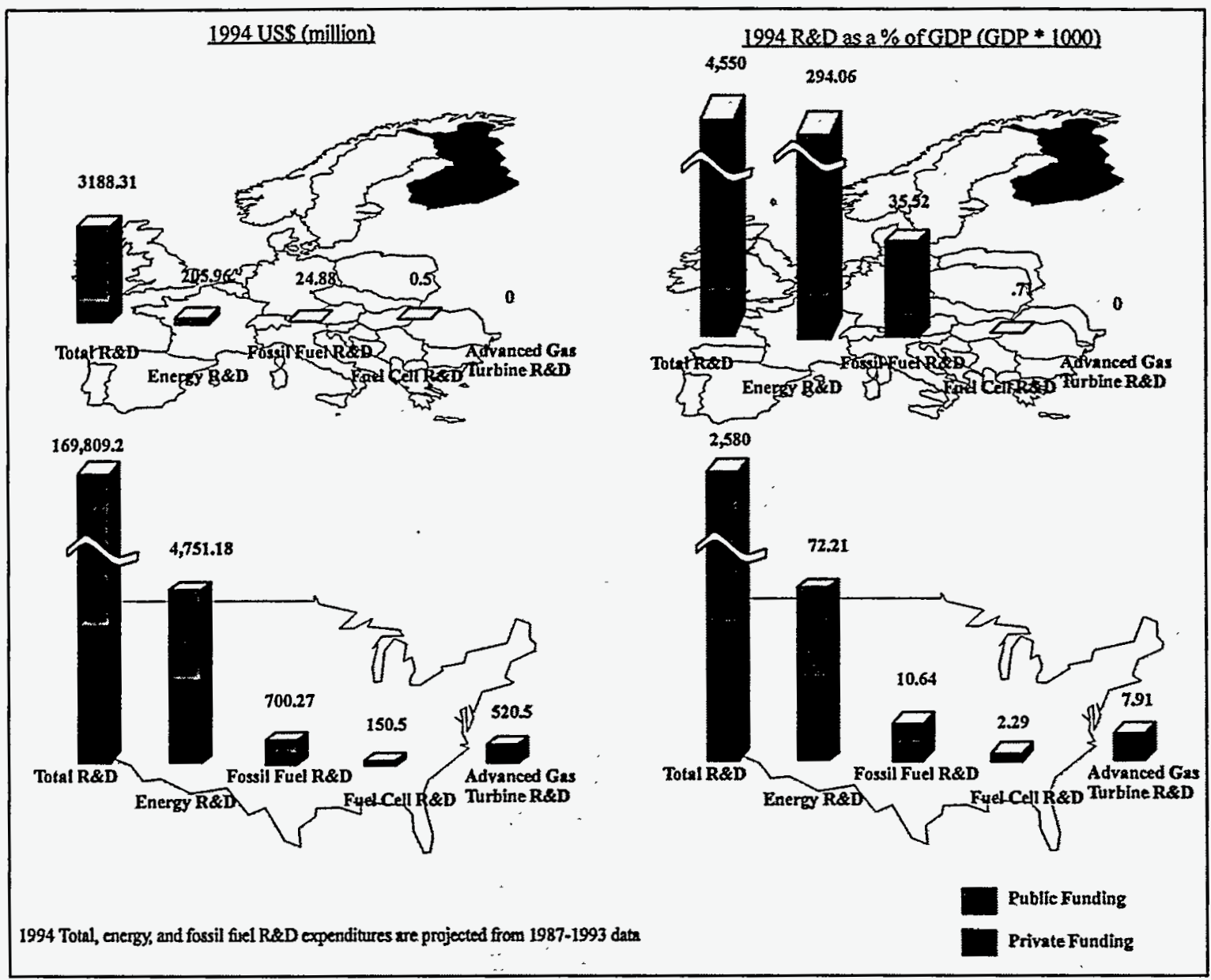

Figure 4.10. Finnish R\&D Expenditures

\subsubsection{R\&D Expenditures}

Finland has increased R\&D funding more rapidly than any other country studied. 1994 total $R \& D$ expenditures for Finland were based on the average annual rate of change in total R\&D funding of $14.1 \%$ (1987-1989). In contrast, the GDP of Finland has decreased more rapidly 
than any other selected country (-15.1\%) (1990-1993). As a result, the ratio of R\&D to GDP in Finland has increased to the highest level of any of the selected countries (4.55\%) (see Figure 4.10). The estimated level of R\&D expenditures in Finland in 1994 was US\$3.19 billion, $0.63 \%$ of the total funding of the selected countries. Energy R\&D in Finland was estimated to receive US\$206 million in 1994. The percentage of total R\&D devoted to energy R\&D (6.46\%) in Finland was close to the average of all selected countries (5.97\%). Due to the decreasing GDP and a $5.0 \%$ annual increase in energy R\&D funding, the energy R\&D to GDP (GDP * 1,000) ratio of $294 \%$ was the second highest of the selected countries. Finland receives a high percentage of its energy R\&D from the private sector $(80 \%)$. Japan is the only country with a higher level of private-level support as a percentage of total. In 1990, approximately US\$16.6 million were allocated to fossil fuel R\&D. After two years of decreasing funding, 1993 expenditures increased to US\$22.5 million. The estimated 1994 level of approximately US $\$ 25$ million was based on the average annual rate of change in funding from 1990-1993 of 10.6\%. Fuel cell R\&D spending in Finland was estimated at less than US\$1 million in 1994. Only one fuel cell project could be identified that received funding from sources in Finland. Advanced gas turbine R\&D funding was assumed negligible.

\subsubsection{R\&D Organizational Structure}

The Ministry of Trade and Industry (MTI) of the Government of Finland coordinates the National Energy Technology Programmes. All Government funding for energy R\&D is provided by MTI, which sets national R\&D policy and directs the national energy research

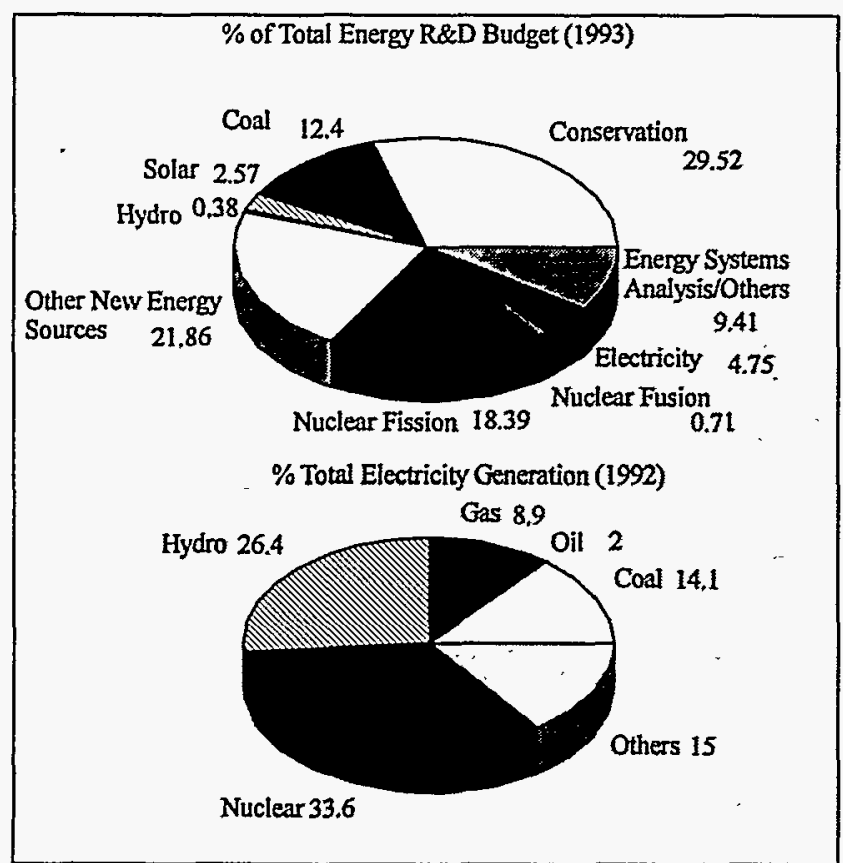

Figure 4.11. Breakdown of Finnish Energy R\&D and Electricity Generation programs. Private sources provide high levels of funding for $R \& D$. Imatran Voime Oy (IVO) company has been involved in various $R \& D$ studies and provides considerable levels of funding for energy R\&D (approx. US $\$ 30$ million/yr).

\subsubsection{Energy R\&D and Sources of Electricity}

Biomass received the highest level of funding for energy R\&D in 1993 whose projects accounted for $20 \%$ of the total Finnish energy R\&D budget. Industrial, residential, and commercial energy conservation received high levels of energy R\&D funding (26.3\%). Nuclear fission and coal also received significant levels of energy $R \& D$ funding in 1993 (18.4\% and $12.4 \%$ of the total budget, respectively) (see Figure 4.11). 
Nuclear, hydro, and fossil fuel play a major role in generating electricity in Finland. Primary sources of electricity generation are predicted to change through the year 2010. Gas is predicted to be used to generate increasingly higher percentages of total electricity. Overall, the dependence on fossil fuels and other non-coal solid fuels is predicted to increase to a total level of almost $67 \%$ of total electricity generation by the year 2010 . In contrast, the use of nuclear and hydro sources are expected to decline to $19.7 \%$ and $14 \%$, respectively, of the total electricity generation.

\subsubsection{Fuel Cell and Advanced Gas Turbine Projects}

Fuel cell R\&D funding was estimated at US $\$ 500,000$ in 1994 . The only identified fuel cell project in Finland is an IVO demonstration of a ONSI $200 \mathrm{~kW}$ PAFC system. This project is in cooperation with EA Technology of the United Kingdom (see Table 4.9). Government funding of fuel cell R\&D was not available, but was believed to be negligible.

Table 4.9. Fuel Cell Project List for Finland

\begin{tabular}{|l|l|l|l|l|}
\hline Project & $\begin{array}{l}\text { Funding } \\
\text { Source }\end{array}$ & Performer & Dates & Funding Level \\
\hline PAFC 200 kW & $\begin{array}{l}\text { IVO } \\
\text { primarily, } \\
\text { ONSI Demo }\end{array}$ & IVO & $1993-1995$ & NA \\
& $\begin{array}{l}\text { Technology } \\
\text { (UK), and UK } \\
\text { regional } \\
\text { electric } \\
\text { companies }\end{array}$ & & & \\
& & & \\
\end{tabular}

Advanced gas turbine R\&D expenditures in Finland were negligible in 1994. Multiple R\&D projects on power plant engineering are located in Finland; however, Finnish sources did not fund any studies on advanced gas turbines (see Table 4.10). All gas turbine projects in Finland involved only the installation, not the manufacturing or $R \& D$, of the advanced gas turbines. IVO participated in research with EPRI and GE to develop hard-wearing materials for gas turbines in cogeneration applications. Any funding that IVO provided, however, was negligible. 
Table 4.10. Advanced Gas Turbine Project List for Finland

\begin{tabular}{|l|l|l|l|l|}
\hline Project & $\begin{array}{l}\text { Funding } \\
\text { Source }\end{array}$ & Performer & Dates & Funding Level \\
\hline None & $\begin{array}{l}\text { Federal } \\
\text { Government }\end{array}$ & NA & NA & None \\
\hline
\end{tabular}




\subsection{France}

France's energy R\&D program focuses on the development of nuclear technologies. Almost $90 \%$ of French energy R\&D funding is allocated to nuclear projects. Nuclear technology provides close to $80 \%$ of the total electricity in France. Fossil fuels are not of primary importance and do not receive a high level of priority in energy R\&D funding or provide a significant level of the generated electricity. Fuel cell R\&D, US\$12 million is minimal compared to the size of the French energy R\&D budget US\$1.14 billion. Advanced gas turbine R\&D is provided primarily by European Gas Turbines (EGT). The French company Alcatel Alsthom owns $45 \%$ of EGT; therefore, advanced gas turbine R\&D carried out by EGT was attributed to France. The total French expenditures for advanced gas turbine R\&D were estimated at US\$22.9 million in 1994.

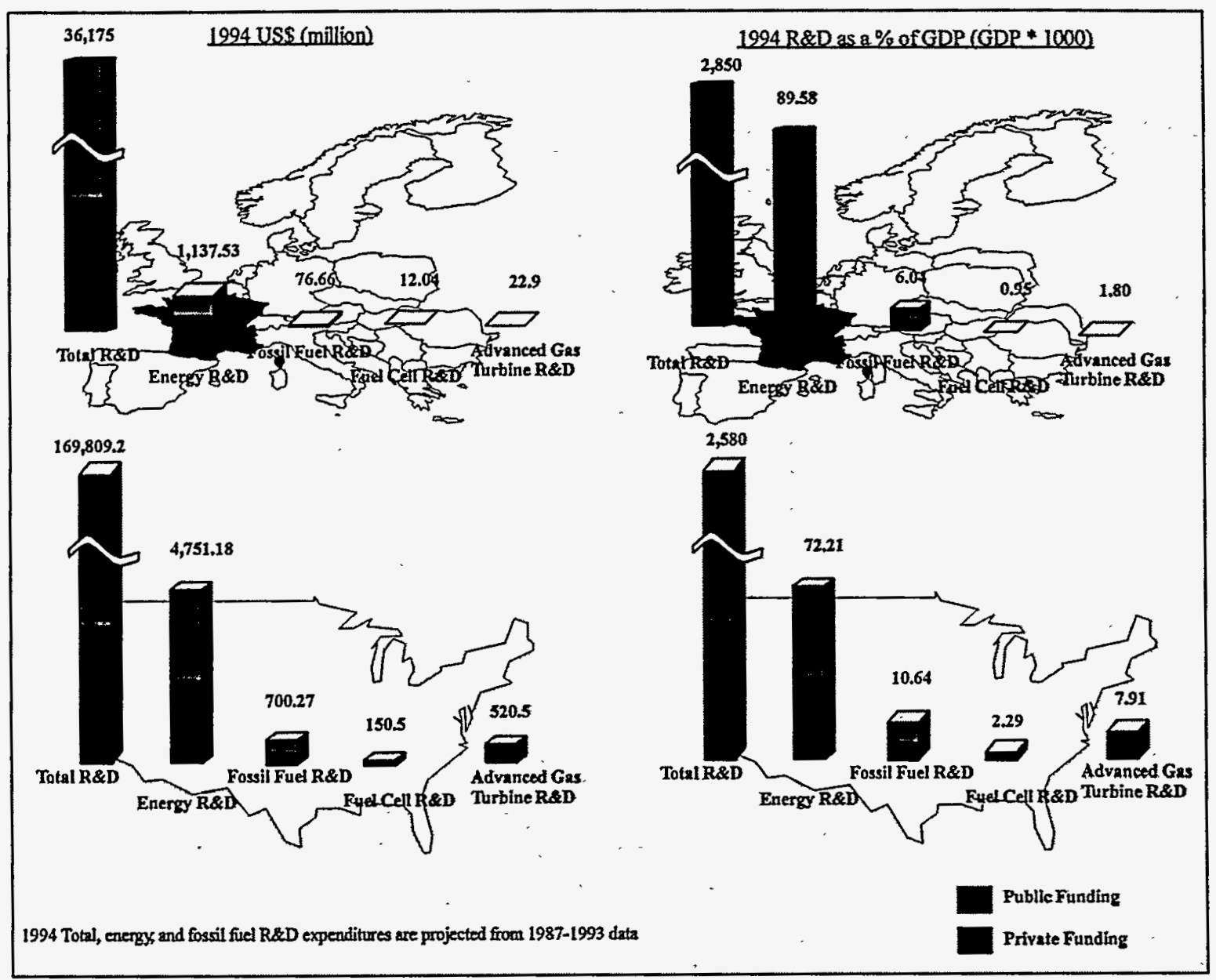

Figure 4.12. French R\&D Expenditures 


\subsubsection{R\&D Expenditures}

France had the fourth largest R\&D budget of the selected countries and the second largest R\&D budget in Europe in 1994. It was estimated that French R\&D expenditures totaled approximately US $\$ 36$ billion, $2.85 \%$ of GDP in 1994 (see Figure 4.12). R\&D expenditures as a percentage of GDP in France are similar to the values in the U.S., Germany, and Japan.

The French R\&D budget increased at an average annual rate of change of $8 \%$ during 19861990 , almost twice the U.S. rate. The contribution of the French private sector increased from a 1986 value of $44 \%$ to a 1990 value of $47.4 \%$ and was estimated at $50.9 \%$ in 1994 . Approximately $3.14 \%$ of the total R\&D was allocated to energy R\&D. The French energy R\&D budget was the third largest of the selected countries. Although the French energy program is relatively large, it received increasingly lower levels of funding over the past several years (1990-1993); the average annual rate of change was $-2.9 \%$. Fossil fuel R\&D expenditures have also decreased; the average annual rate of change was $-5.58 \%(1990$ 1993). The French fossil fuel R\&D budget of approximately US $\$ 77$ million was the fifth largest of the selected countries. French fuel-cell R\&D funding was estimated at US $\$ 12$ million in 1994. The majority of this funding is concerned with development of polymer electrolyte fuel cells. Public sources provided approximately $85 \%$ of the total fuel cell funding. Advanced gas turbine R\&D funding was estimated at US\$24 million in 1994. Approximately $80 \%$ of the total gas turbine R\&D funding was estimated to come from private sources. Although there are significant levels of fuel cell and advanced gas turbine R\&D funding in France, the levels are not among the highest levels of the selected countries.

\subsubsection{R\&D Organizational Structure}

The following national ministries provide funding for energy R\&D:

- Ministry of Industry and External Trade. Designs and implements energy and industrial policy and supervises the operation of state-owned energy companies and their subsidiaries, which include the French Atomic Energy Commission, Electricite de France (EDF), Charbonnages de France, and Gaz de France. (EDF is the largest electric utility in the world and maintains a large annual R\&D budget.) Provides funding for energy companies, French Atomic Energy Commission, and various public industrial and commercial establishments.

- Ministry of Defense. Provides funding for the French Atomic Energy Commission and various public industrial and commercial establishments.

- Ministry of Environment. Provides funding for the Agency for Environment and Energy Management and various public industrial and commercial establishments. The Agency for Environment and Energy Management implements government policy on 
energy and conservation and renewable energy sources and manages much of France's environmental policy.

- Ministry of Research and Space. Provides funding for public industrial and commerical establishments, public scientific and technical establishments, biology and medicine research, and universities. In 1992, the Ministry changed its name from the Ministry of Research and Technology. In 1990, it controlled $54 \%$ of the total federal R\&D budget.

- Ministry of National Education and Culture. Provides funding for universities and oversees civil research carried out by most of the major public research organization's agencies, and universities.

\subsubsection{Energy R\&D and Sources of Electricity}

France's energy sector is dominated by nuclear technology. In $1993,88.16 \%$ of the country's energy R\&D budget was devoted to nuclear R\&D, nuclear technology generated

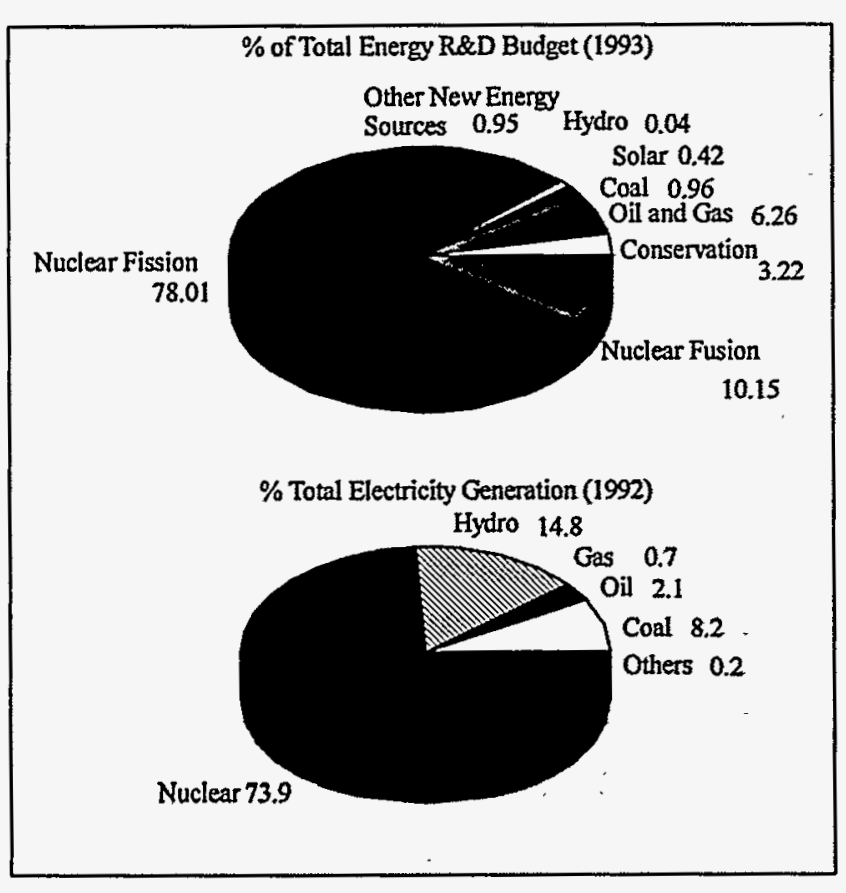

Figure 4.13. Breakdown of French Energy R\&D and Electricity Generation
$74 \%$ of the total electricity in 1992 . Fossil fuels play a minor role in the energy programs of France. Approximately 7.2\% of the total French energy R\&D was devoted to fossil fuel. Of the total electricity in France, $11 \%$ was generated by fossil fuel sources. Hydroelectric power provided close to $15 \%$ of the total French generated electricity in 1992; however, hydroelectric technology received only $0.04 \%$ of the total energy R\&D budget (see Figure 4.13).

French dependence on nuclear technology for electricity generation is projected to increase over the next 15 years. By the year 2010, nuclear technology is projected to provide $80 \%$ of the country's total electricity. Fossil fuel dependence is projected to remain relatively flat over the same period. Decreases in coal and oil consumption are expected to be offset by gradually increased use of gas to generate electricity. 


\subsubsection{Fuel Cell and Advanced Gas Turbine Projects}

French fuel cell R\&D funding was estimated at US\$12 million in 1994. Although fuel cell R\&D is not as highly funded in France as in other selected countries, the level of PEFC R\&D funding is increasing. Ademe, Commissariat a l'energie atomique (CEA), Centre national de la recherche scientifique (CNRS), SORAPEC, and Renault are involved in R\&D of polymer electrolyte fuel cells (see Table 4.11). Ademe was involved in various projects involving R\&D on PEFCs and one on DMFC. Ademe has an advanced technology budget of 45 million French Francs (FF) for 1994. Included in the advanced technology budget are fuel cells and hybrid vehicles. In addition, Ademe indicated participation in fuel cell programs of the EU underneath the JOULE, BRITE/EURAM, and AIE programs. Ademe is providing 25 million $\mathrm{FF}$ over five years for a clean and efficient vehicle project being performed by CEA, CNRS, Sorapec, and GIE rechereche (a consortium between Renault and PSA), 2 million FF over three years for a DMFC project, and is estimated to three spend an additional 20 million FF/yr. on various fuel cell activities. Electricite de France had a total R\&D budget of US\$543 million in 1993. Fossil fuel technology R\&D projects were listed as accounting for US\$54.3 million in 1993. It was estimated that fuel cells accounted for approximately US\$5.4 million (10\%) of the total fossil fuel R\&D budget of EDF. At this level, EDF would be able to support two-to-three small fuel cell R\&D projects and would have a budget similar in size to that of Ademe. Gaz de France indicated fuel cell R\&D on CHP expenditures of 0.5 million FF for 1994 and 2.5 million FF for 1995. Sorapec is involved in manufacturing PEFCs and are investing funds in applicable R\&D. Sorapec R\&D funding levels were not available.

Table 4.11. Fuel Cell Project List for France

\begin{tabular}{|c|c|c|c|c|}
\hline Project & $\begin{array}{l}\text { Funding } \\
\text { Source }\end{array}$ & Performer & Dates & $\begin{array}{l}\text { Funding Level } \\
\text { US\$ (million) }\end{array}$ \\
\hline $\begin{array}{l}\text { SOFC stack } \\
\text { development }\end{array}$ & EU & Sapco & $\mathrm{NA}$ & $\overline{\mathrm{NA}}$ \\
\hline $\begin{array}{l}\text { DMFC } \\
\text { dispersed } \\
\text { catalysts }\end{array}$ & $\begin{array}{l}\text { Ademe, } \\
\text { KFA Julich }\end{array}$ & $\begin{array}{l}\text { University of } \\
\text { Poitiers }\end{array}$ & \begin{tabular}{|l|}
$5 / 5 / 93-5 / 5 / 96$ \\
\end{tabular} & .5 \\
\hline $\begin{array}{l}\text { DMFC } \\
\text { inorganic } \\
\text { electrolyte }\end{array}$ & $50 \%$ from $\mathrm{EU}$ & $\begin{array}{l}\text { University of } \\
\text { Poitiers, } \\
\text { University of } \\
\text { Bonn }\end{array}$ & Ongoing & $\overline{\mathrm{NA}}$ \\
\hline $\begin{array}{l}\text { AFC battery } \\
\text { supply to } \\
\text { Elenco }\end{array}$ & Elenco & SAFT & \begin{tabular}{|l|} 
1991-Present \\
\end{tabular} & NA \\
\hline $\begin{array}{l}\text { PEFC } \\
\text { manufacturing }\end{array}$ & Sorapec & Sorapec & $\mathrm{NA}$ & $\mathrm{NA}$ \\
\hline
\end{tabular}




\section{Table 4.11. Continued.}

\begin{tabular}{|l|l|l|l|l|}
\hline $\begin{array}{l}\text { Advanced } \\
\text { Technologies }\end{array}$ & Ademe & Various & 3.7 \\
\hline $\begin{array}{l}\text { PEFC } \\
\text { vehicular }\end{array}$ & $\begin{array}{l}\text { CEA, CNRS, } \\
\text { SORAPEC } \\
\text { Ademe (50\%) }\end{array}$ & $\begin{array}{l}\text { GIE recherche } \\
\text { (consortium } \\
\text { PSA/Renault) }\end{array}$ & $\begin{array}{l}1992-1997(5 \\
\text { yrs.) }\end{array}$ & 1.8 \\
\hline CHP fuel cells & Gaz de France & Gaz de France & 1994 & .1996 \\
\hline $\begin{array}{l}\text { EDF estimate } \\
\text { EEFC } \\
\text { Electrolyte } \\
\text { Development }\end{array}$ & $\begin{array}{l}\text { Electricite de } \\
\text { France }\end{array}$ & $\begin{array}{l}\text { Electricite de } \\
\text { France }\end{array}$ & 1993 & 5.4 \\
\hline
\end{tabular}

French advanced gas turbine R\&D expenditures were estimated at US\$24 million in 1994. The two major funders of advanced gas turbine R\&D in France, are Electricite de France and European Gas Turbines. French government expenditures on advanced gas turbine R\&D outside of that provided by EDF were estimated as negligible. EDF advanced gas turbine R\&D funding levels were estimated in the same manner as fuel cell $R \& D$ expenditures (see Table 4.12).

European Gas Turbines (EGT) is involved in manufacturing, research, and development of advanced gas turbines. EGT sells the TYPHOON, TORNADO, HURRICANE, and various other gas turbines. EGT has established a Joint Technology Office with General Electric to promote technological collaboration on a broad front. The Joint Technology Office has performed research on a wide range of design studies for both industrial and marine applications and aero engine projects. In addition, the Joint Technology Office has released a dry low $\mathrm{NO}_{\mathrm{x}}$ system for its Frame 3 and 5 gas turbines. EGT is $90 \%$ owned by GEC Alsthom and $10 \%$ owned by General Electric. GEC Alsthom is $50 \%$ owned by GEC of the United Kingdom and $50 \%$ by Alcatel Alsthom of France. Therefore, European Gas Turbines is $45 \%$ owned by Alcatel Alsthom, it was assumed that $45 \%$ of the advanced gas turbine R\&D expenditures were attributable to French sources. EGT has had R\&D expenditures of approximately 50 million ECU (US $\$ 40$ million) over each of the past three years (19931991). One hundred percent of EGT R\&D was estimated to be directed to advanced gas turbine R\&D. EGT has recently modified its TYPHOON gas turbines to operate on lowcalorific value feed gas resulting from the gasification of biomass in Sweden. 
Table 4.12. Advanced Gas Turbine Project List for France

\begin{tabular}{|l|l|l|l|l|}
\hline Project & $\begin{array}{l}\text { Funding } \\
\text { Source }\end{array}$ & Performer & Dates & $\begin{array}{l}\text { Funding Level } \\
\text { US\$ (million)* }\end{array}$ \\
\hline None & Government & NA & NA & None \\
\hline Various & $\begin{array}{l}\text { Electricite de } \\
\text { France }\end{array}$ & Various & 1993 & 5.4 \\
\hline Various & $\begin{array}{l}\text { GEC Alsthom, } \\
\text { EGT }\end{array}$ & Various & 1993 & 17.5 \\
& & & 1992 & 19.9 \\
& & & 1991 & 17.9 \\
\hline
\end{tabular}

* Estimated levels of expenditures. 


\subsection{Germany}

Germany has the largest $R \& D$ program in Europe and the third largest of the selected countries. The German R\&D program receives funding from the federal government, the Lander governments, and industry. Fuel cell and advanced gas turbine R\&D is supported throughout Germany. Polymer electrolyte fuel cells receive the greatest level of fuel-cell R\&D funding in the country. Seimens is the greatest contributor to advanced gas turbine R\&D funding.

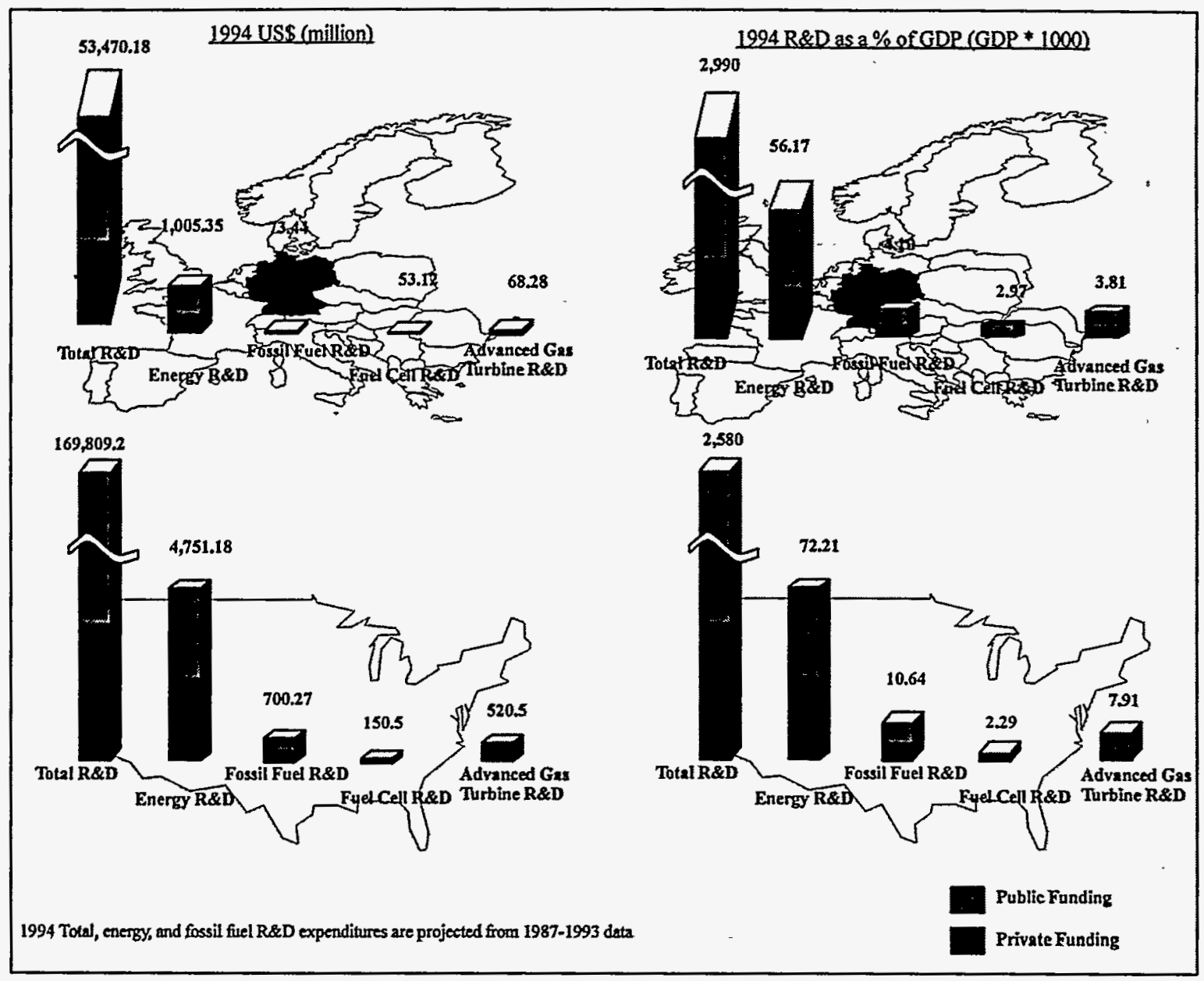

Figure 4.14. German R\&D Expenditures

\subsubsection{R\&D Expenditures}

Germany is estimated to have spent US\$53.5 billion on R\&D in 1994 (see Figure 4.14). R\&D as a percentage of GDP in Germany was 3\% in 1994, greater than the U.S. level of $2.58 \%$. German R\&D expenditures accounted for $10.6 \%$ of the total $R \& D$ expenditures of 
the selected countries. The German R\&D budget has increased at an average annual rate of $6.44 \%$. At this rate, the German budget is increasing more slowly than the average rate of the selected countries $(7.09 \%)$ but more rapidly than the U.S. rate of $4.1 \%$. Energy R\&D in Germany accounted for $1.9 \%$ of the total R\&D budget, lower than the U.S. level of $2.8 \%$ and the lowest of the selected countries. Germany's average annual rate of change in energy $R \& D$ funding was approximately $-8 \%$ over the past several years. Its R\&D energy budget decreased from a 1988 level of US $\$ 1.65$ billion to a 1993 level of US $\$ 1.092$ billion. In addition, fossil fuel $R \& D$ funding in Germany decreased rapidly over the past several years. In 1988, the fossil fuel R\&D funding totaled US\$236 million as compared to the 1993 budget of approximately US\$98 million. The decrease in annual fossil fuel R\&D funding has caused Germany to have one of the lowest levels of fossil fuel R\&D expenditures as a percentage of GDP (GDP * 1,000), 4.1\%.

\subsubsection{R\&D Organizational Structure}

The primary R\&D funding sources in Germany are the federal government, the Lander governments, and industry. The federal government and the Lander together form the Federal/Lander Commission for Educational Planning and Research Promotion. This commission was established to promote cooperation between the federal and Lander governments in educational planning and in the promotion of institutions and scientific research projects of supra-regional importance. These three R\&D funding sources assist many of the same R\&D institutions and programs. For example, the Max Planck Society receives funding from the federal government, the Lander governments, and industry.

- Federal government. Funds the European Commission, the German Research Foundation, the national research centers, the Max Planck Society, the "Blue List," the Fraunhofer Society, federal research institutions, corporate research laboratories, the Industrial Cooperative Research Association, and industry-related R\&D institutions.

- Lander governments. Provides funding for German Research Foundation, national research centers, Max Planck Society, Fraunhofer Society, the "Blue List," higher education sector, various Lander institutes, and the academies.

-Industry. Provides funding for corporate research laboratories, Industrial Cooperative Research Association, industry-related R\&D institutions, higher education sector, national research centers, Max Planck Society, Fraunhofer Society, and the "Blue List."

The national research centers, a central part of the German research program provide largescale equipment for research, manage sophisticated technical infrastructures, and provide concentrated capabilities for handling complex interdisciplinary issues. The Max Planck Society currently operates 101 research facilities that concentrate primarily on basic research in the humanities and sciences. The Fraunhofer Society aims to promote the practical application of scientific findings in the area of applied research. The "Blue List" comprises 
82 institutions that have a serving function for research of supra-regional importance and national scientific interest. "Blue List" organizations constitute one of the cornerstones of German research

\subsubsection{Energy R\&D and Sources of Electricity and Electricity Generation}

Figure 4.15 shows the breakdown of German energy R\&D and electricity generation. Germany is focusing its energy R\&D on non fossil-fuel activities. Nuclear technologies accounted for $55.5 \%$, solar for $19.2 \%$, and other new energy sources for $7.6 \%$ of the total energy R\&D budget. Nuclear supporting technologies (19.3\%) and solar photo electric (14\%) subgroups collected the highest levels of energy R\&D support. Fossil fuels accounted for a little more than $9 \%$ of the total energy R\&D budget in 1993. Fossil fuel R\&D was centered on coal combustion projects.

Coal and nuclear technologies are the primary methods for electricity generation in Germany, providing close to $90 \%$ of the electricity generated in the country in 1992. Gas is projected to occupy more of the electricity generation market in 2010. Projections estimate that up to

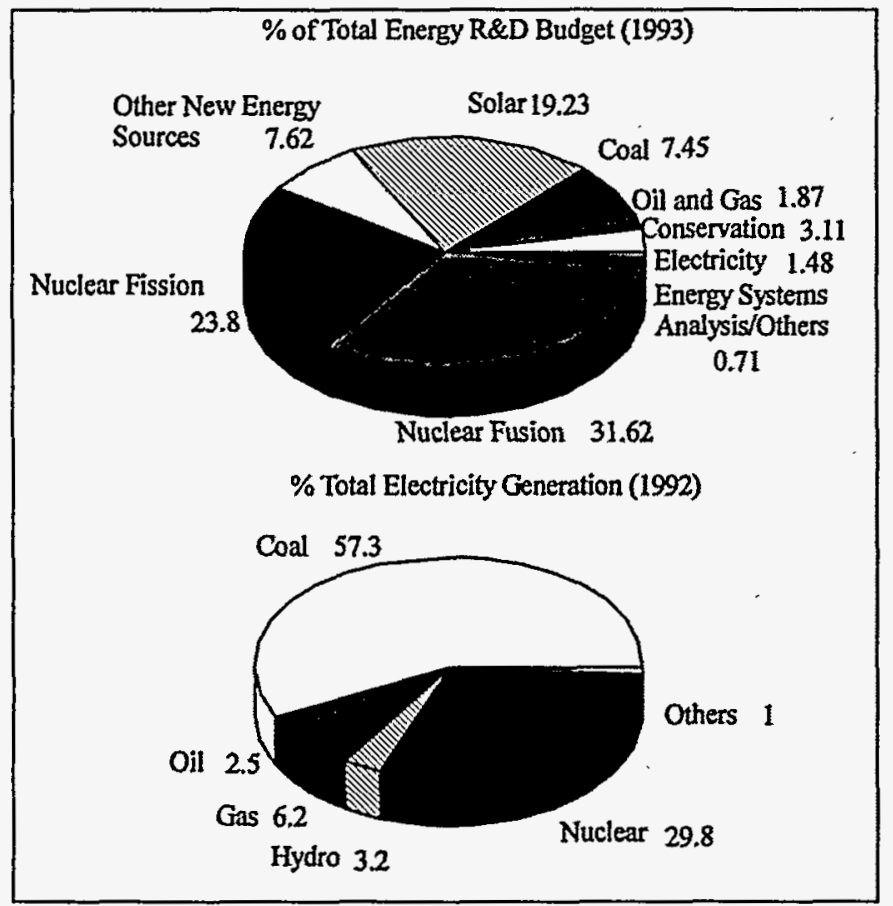

Figure 4.15. Breakdown of German Energy R\&D and Electricity Generation $15 \%$ of the total generated electricity will be by gas in the year 2010 .

\subsubsection{Fuel Cell and Advanced Gas Turbine Projects}

Fuel cell R\&D expenditures were estimated at US\$53 million in 1994, the largest fuel cell program in Europe. PAFC, MCFC, SOFC, PEFC, and DMCF projects have been identified (see Table 4.13). The largest level of $R \& D$ funding was provided for PEFC applications. Daimler Benz, BMW, Deutsche Babcock, Seimens, and KFA Julich are active in PEFC research. Daimler Benz is estimated to provide approximately US $\$ 20$ million/yr. on PEFC R\&D. BMW has been involved in a 10 year PEFC project with a total budget of approximately US\$87 million. The German government supports PEFC R\&D at a level of approximately US $\$ 2.9$ million/yr. SOFC activities are led by Seimens, which appropriates approximately US $\$ 2.7$ million/yr. to SOFC R\&D. Dornier also has a large SOFC R\&D program; its annual funding level is approximately US $\$ 1.1$ million. The German 
government supports a SOFC R\&D program managed by KFA Julich Research Center that involves a number of industrial groups. The only significant MCFC R\&D program in Germany is led by Daimler Benz, through MTU. The program aims to develop MCFC systems from stack technology licensed by Energy Research Corporation (U.S.) The program was estimated to have an annual funding level of approximately US\$4 million. Four PAFC projects are being funded by Thyssengas, KTI/Solar, Ruhrgas, and HEAG. Each of these involves demonstration of PAFC stacks developed in other countries. The total funding for PAFC R\&D was estimated at US\$4 million. Two small but rapidly progressing, DMFC projects have been identified. One, at the University of Bonn, and another supported by Seimens, were estimated to have total expenditures of US $\$ 500,000$.

Table 4.13. Fuel Cell Project List for Germany

\begin{tabular}{|c|c|c|c|c|}
\hline Project & $\begin{array}{l}\text { Funding } \\
\text { Source }\end{array}$ & Performer & Dates & $\begin{array}{l}\text { Funding Level } \\
\text { US\$ (million) }\end{array}$ \\
\hline $\begin{array}{l}\text { MCFC pilot } \\
\text { plant }\end{array}$ & $\begin{array}{l}\text { Federal } \\
\text { Government } \\
\\
\text { Deutsche } \\
\text { Aerospace }\end{array}$ & $\begin{array}{l}\text { Deutsche } \\
\text { Aerospace } \\
\text { Energy } \\
\text { Research } \\
\text { Corporation } \\
\text { (U.S.) }\end{array}$ & $1990-1994$ & $\begin{array}{l}14(50 \% \\
\text { government, } \\
50 \% \text { private })\end{array}$ \\
\hline $\begin{array}{l}\text { MCFC system. } \\
\text { development } \\
\text { and } \\
\text { demonstration }\end{array}$ & $\begin{array}{l}\text { MTU, } \\
\text { Ruhrgas, } \\
\text { Haldor Topsoe } \\
\text { (Denmark), } \\
\text { Elkraft } \\
\text { (Denmark) }\end{array}$ & $\begin{array}{l}\text { MTU } \\
\text { Ruhrgas, } \\
\text { Haldor Topsoe, } \\
\text { Elkraft }\end{array}$ & $1991-1995$ & 20 \\
\hline $\begin{array}{l}\text { PAFC } \\
\text { Demonstration } \\
\text { Natural Gas }\end{array}$ & Ruhrgas & $\begin{array}{l}\text { Ruhrgas (ONSI } \\
\text { stack) }\end{array}$ & Since 1993 & $\overline{\mathrm{NA}}$ \\
\hline $\begin{array}{l}\text { PAFC Demo } \\
\text { Nat. Gas }\end{array}$ & Thyssengas & $\begin{array}{l}\text { Thyssengas } \\
\text { (ONSI stack) }\end{array}$ & NA & $\overline{\mathrm{NA}}$ \\
\hline $\begin{array}{l}\text { PAFC } \\
\text { Demonstration } \\
\text { Natural Gas }\end{array}$ & $\overline{\mathrm{HEAG}}$ & $\begin{array}{l}\text { HEAG (ONSI } \\
\text { stack) }\end{array}$ & $\overline{\mathrm{NA}}$ & $\overline{\mathrm{NA}}$ \\
\hline $\begin{array}{l}\text { PAFC } \\
\text { Demonstration } \\
\text { Hydrogen }\end{array}$ & $\begin{array}{l}\text { KTI/Solar- } \\
\text { Wasserstoff } \\
\text { Bayern }\end{array}$ & $\begin{array}{l}\text { KTI/Solar } \\
\text { (ONSI stack) }\end{array}$ & $\overline{N A}$ & $\mathrm{NA}$ \\
\hline
\end{tabular}


Table 4.13 Continued

\begin{tabular}{|c|c|c|c|c|}
\hline Project & \begin{tabular}{|l|} 
Funding \\
Source
\end{tabular} & Performer & Dates & $\begin{array}{l}\text { Funding Level } \\
\text { US\$ (million) }\end{array}$ \\
\hline $\begin{array}{l}\text { PEFC stack for } \\
\text { transportation }\end{array}$ & $\begin{array}{l}\text { Siemens, } \\
\text { EU (50\%) }\end{array}$ & $\begin{array}{l}\text { Siemens, } \\
\text { AEA } \\
\text { Technology, } \\
\text { CEA, } \\
\text { PSI }\end{array}$ & 1992-present & 3.5 \\
\hline $\begin{array}{l}\text { PEFC stack } \\
\text { evaluation }\end{array}$ & Daimler Benz & $\begin{array}{l}\text { Daimler Benz, } \\
\text { Ballard (Can) }\end{array}$ & 1990-present & 60 \\
\hline $\begin{array}{l}\text { PEFC stack } \\
\text { development }\end{array}$ & $\begin{array}{l}\text { Daimler Benz } \\
(70 \%), \\
\text { Ballard (Can) } \\
(30 \%)\end{array}$ & $\begin{array}{l}\text { Daimler Benz, } \\
\text { Ballard (Can.) }\end{array}$ & 1993-1997 & 35 \\
\hline $\begin{array}{l}\text { PEFC } \\
\text { methanol } \\
\text { reformer } \\
\text { development }\end{array}$ & $\begin{array}{l}\text { KFA Julich, } \\
\text { Haldor Topsoe } \\
\text { (Denmark), } \\
\text { EU }(50 \%)\end{array}$ & $\begin{array}{l}\text { KFA Julich, } \\
\text { Haldor Topsoe }\end{array}$ & 1992 - present & $\overline{\mathrm{NA}}$ \\
\hline $\begin{array}{l}\text { PEFC } \\
\text { (hydrogen } \\
\text { economic } \\
\text { activities) }\end{array}$ & $\begin{array}{l}\text { BMW, } \\
\text { SWB, } \\
\text { DASA, } \\
\text { Linde }\end{array}$ & $\begin{array}{l}\text { BMW, } \\
\text { SWB, } \\
\text { DASA, } \\
\text { Linde }\end{array}$ & $1987-1996$ & 87 \\
\hline $\begin{array}{l}\text { DMFC stack } \\
\text { development }\end{array}$ & $\begin{array}{l}\text { Siemens, } \\
\text { EU (50\%) }\end{array}$ & Siemens & 1992 - present & $\overline{\mathrm{NA}}$ \\
\hline $\begin{array}{l}\text { DMFC inorg. } \\
\text { electricity } \\
\text { development }\end{array}$ & $\mathrm{EU}(>50 \%)$ & $\begin{array}{l}\text { University of } \\
\text { Bonn, } \\
\text { University of } \\
\text { Poitiers }\end{array}$ & & $\overline{\mathrm{NA}}$ \\
\hline $\begin{array}{l}\text { AFC stack } \\
\text { development }\end{array}$ & Siemens & Siemens & pre-1988 & $\overline{\mathrm{NA}}$ \\
\hline $\begin{array}{l}\text { AFC } \\
\text { development }\end{array}$ & Hoescht & Hoescht & $\overline{\mathrm{NA}}$ & $\overline{\mathrm{NA}}$ \\
\hline $\begin{array}{l}\text { Ceramic for } \\
\text { Fuel Cells }\end{array}$ & Government & $\begin{array}{l}\text { Fraunhofer } \\
\text { Gesellschaft } \\
\text { (Government } \\
\text { res. } \\
\text { organization) }\end{array}$ & $1992-1993$ & .6 \\
\hline
\end{tabular}


Table 4.13. Continued.

\begin{tabular}{|c|c|c|c|c|}
\hline Project & $\begin{array}{l}\text { Funding } \\
\text { Source }\end{array}$ & Performer & Dates & $\begin{array}{l}\text { Funding Level } \\
\text { US\$ (million) }\end{array}$ \\
\hline $\begin{array}{l}\text { SOFC } \\
\text { development } \\
\text { and application }\end{array}$ & $\begin{array}{l}\text { Seimens, } \\
\text { Federal } \\
\text { Government }\end{array}$ & Siemens & 1991-1993 & 8 \\
\hline $\begin{array}{l}\text { SOFC } \\
\text { prototype }\end{array}$ & $\begin{array}{l}\text { Dornier, } \\
\text { Federal } \\
\text { Government }\end{array}$ & Dornier & $1991-1993$ & 3 \\
\hline
\end{tabular}

Germany has a large and active advanced gas turbine research and development program. The estimated 1994 expenditures on advanced gas turbine R\&D in Germany was US\$68 million. Funding for advanced gas turbine R\&D in Germany was determined to come from two primary sources.

Siemens had 1993 revenues of close to US $\$ 50$ billion and total R\&D expenditures of approximately US $\$ 5$ billion. Government support for Siemens R\&D accounted for only $2 \%$ of their total R\&D budget. Siemens employs more than 48,000 workers in $R \& D$. Gas turbine sales for Siemens are included within the fossil fuel section of the power generation group. The power generation group had sales of approximately $10 \%$ of the total company sales; fossil fuel sales, which comprised close to $20 \%$ of total power generation sales, included integrated coal gasification combined cycle development, as well as gas turbine R\&D. Of the total R\&D budget, US $\$ 60$ million was estimated to be allocated to advanced gas turbine R\&D. Siemens advanced gas turbine R\&D program focuses on improvements in efficiency and power output and reduction in emissions of $\mathrm{NO}_{\mathrm{X}}, \mathrm{CO}$, and UHC. In 1993, the V84.3 model gas turbine achieved a nominal rating of $152 \mathrm{MW}$ and a simple-cycle base load efficiency of $36.1 \%$.

German government gas turbine $R \& D$ was supported through the Ministry of Education, Science, Research, and Technology, as well as through the German Aerospace Research Establishment, which has maintained a 100 million Deutch Mark (DM) R\&D program over the past 10 years. The funding for this project was split evenly between the German government and private companies. Industry is required to match government funding; however, nonprofit organizations and universities are generally provided $100 \%$ funding. Table 4.14 lists the projects and funding levels of this program. The leading private companies include ABB, BMW-Rolls Royce, Motoren- und Turbineunion, Seimens, and Daimler Benz. 
Table 4.14. Advanced Gas Turbine Project List for Germany

\begin{tabular}{|c|c|c|c|c|}
\hline Project & $\begin{array}{l}\text { Funding } \\
\text { Source }\end{array}$ & Performer & Dates & $\begin{array}{l}\text { Funding Level } \\
\text { USS (million) }\end{array}$ \\
\hline $\begin{array}{l}\text { Total Gas } \\
\text { Turbines }\end{array}$ & $\begin{array}{l}\text { Government } \\
\text { (Ministry of } \\
\text { Education, } \\
\text { Science, } \\
\text { Reserch and } \\
\text { Technology) }\end{array}$ & Various & $\begin{array}{l}1992 \\
1993 \\
1994\end{array}$ & $\begin{array}{l}1.9 \\
1.0 \\
1.2\end{array}$ \\
\hline Various & Seimens & Seimens & $\begin{array}{l}1993 \\
1992\end{array}$ & $\begin{array}{l}60^{*} \\
60.7^{*}\end{array}$ \\
\hline $\begin{array}{l}\text { German } \\
\text { Aerospace } \\
\text { Research } \\
\text { Establishment }\end{array}$ & $\begin{array}{l}\text { Government } \\
(50 \%) \\
\text { Private (50\%) }\end{array}$ & Various & 1986-1995 & 62.7 \\
\hline \multicolumn{5}{|c|}{$\begin{array}{l}\text { All further projects are in cooperation with the German Aerospace Research } \\
\text { Establishment project and their funding is included in the US\$62.7 million shown } \\
\text { above. All funding levels for further projects are in German DM. }\end{array}$} \\
\hline & $\begin{array}{l}\mathrm{ABB} \\
\text { Kraftwerke }\end{array}$ & & $\begin{array}{c}1986-1993 \\
1987-1992 \\
1989-1993 \\
1992-1995 \\
1992-1995\end{array}$ & $\begin{array}{l}1.44 \\
.75 \\
.71 \\
1.47 \\
1.29\end{array}$ \\
\hline & $\begin{array}{l}\text { Deutsche } \\
\text { Forschungsanst } \\
\text { alt fur Luft und } \\
\text { Raumfahrt }\end{array}$ & & $\begin{array}{l}1991-1994 \\
1991-1995\end{array}$ & $\begin{array}{l}.52 \\
5.47\end{array}$ \\
\hline & $\begin{array}{l}\text { BMW Rolls } \\
\text { Royce }\end{array}$ & & $\begin{array}{l}1989-1994 \\
1989-1993 \\
1992-1996\end{array}$ & $\begin{array}{l}2.34 \\
3.33 \\
1.11\end{array}$ \\
\hline & $\begin{array}{l}\text { Motoren und } \\
\text { Turbinenunion } \\
\text { (MTU) }\end{array}$ & & $\begin{array}{l}1989-1992 \\
1990-1994 \\
1992-1996\end{array}$ & $\begin{array}{l}3.78 \\
3.12 \\
.58\end{array}$ \\
\hline
\end{tabular}


Table 4.14. Continued.

\begin{tabular}{|c|c|c|c|c|}
\hline Project & $\begin{array}{l}\text { Funding } \\
\text { Source }\end{array}$ & Performer & Dates & $\begin{array}{l}\text { Funding Level } \\
\text { USS (million) }\end{array}$ \\
\hline & Siemens & & $\begin{array}{l}1986-1993 \\
1989-1993 \\
1990-1993\end{array}$ & $\begin{array}{l}1.83 \\
3.07\end{array}$ \\
\hline & Daimler-Benz & & $1990-1994$ & .32 \\
\hline & $\begin{array}{l}\text { Energiewerke } \\
\text { Schwarze } \\
\text { Pumpe }\end{array}$ & & 1991-1993 & .70 \\
\hline & $\begin{array}{l}\text { Fichtner Dev. } \\
\text { Engineering }\end{array}$ & & 1992 & 8.72 \\
\hline & $\begin{array}{l}\text { Bundesanstalt } \\
\text { fur } \\
\text { Materilprufung }\end{array}$ & & $1992-1993$ & 1.53 \\
\hline & Universities & & $\begin{array}{l}1986-1995 \\
\end{array}$ & 1.18 \\
\hline & Aachen Tech & & 1986-1995 & 1.07 \\
\hline & $\begin{array}{l}\text { Darmstadt } \\
\text { Tech }\end{array}$ & & 1986-1994 & 2.33 \\
\hline & Munich Tech & & 1986-1994 & .57 \\
\hline & Bochum & & \begin{tabular}{|c|}
$1989-1994$ \\
\end{tabular} & .30 \\
\hline & Karlsruhe & & 1989-1994 & .26 \\
\hline & Zittau/Gorlitz & & $1992-1995$ & .68 \\
\hline & Munich Army & & \begin{tabular}{|l|}
$1989-1993$ \\
\end{tabular} & 1.35 \\
\hline & Hannover & & $1990-1994$ & .44 \\
\hline & Stuttgart & & \begin{tabular}{|l|}
$1989-1994$ \\
\end{tabular} & 1.02 \\
\hline & $\begin{array}{l}\text { Braunschweig } \\
\text { Technology }\end{array}$ & & \begin{tabular}{|c|}
$1989-1993$ \\
\end{tabular} & .47 \\
\hline & $\begin{array}{l}\text { Clausthal } \\
\text { Technology }\end{array}$ & & \begin{tabular}{|c|}
$1989-1992$ \\
\end{tabular} & .82 \\
\hline
\end{tabular}


Table 4.14. Continued

\begin{tabular}{|l|l|l|l|l|}
\hline Project & $\begin{array}{l}\text { Funding } \\
\text { Source }\end{array}$ & Performer & Dates & $\begin{array}{l}\text { Funding Level } \\
\text { US\$ (million) }\end{array}$ \\
\hline & $\begin{array}{l}\text { Dresden } \\
\text { Technology }\end{array}$ & & $1992-1996$ & .67 \\
\hline & $\begin{array}{l}\text { Magdeburg } \\
\text { Technology }\end{array}$ & & $1991-1993$ & NA \\
\hline & Essen & & $1990-1993$ & NA \\
\hline & $\begin{array}{l}\text { Deutsches } \\
\text { Brennstoffinstit } \\
\text { ut (German } \\
\text { Fuel Institute) }\end{array}$ & & $1991-1992$ & NA \\
\hline
\end{tabular}

* Estimated levels of expenditures. 


\subsection{Italy}

R\&D's role in Italy has gone through major transformations over the past several years. Budget constraints in response to the fairly dynamic political situation have precipitated major changes in funding priorities and procedures. The total energy related R\&D funding decreased from a 1988 level of $10.2 \%$ of total R\&D to a 1992 level of $5 \%$. Many agencies and establishments are involved in research, development, and dissemination. Energy R\&D concentrates on fossil fuels, renewables and conservation, and nuclear technologies. The Italian fuel cell R\&D program was estimated as the second largest in Europe, with a total funding of US\$29.7 million. Advanced gas turbine R\&D received negligible support in 1994.

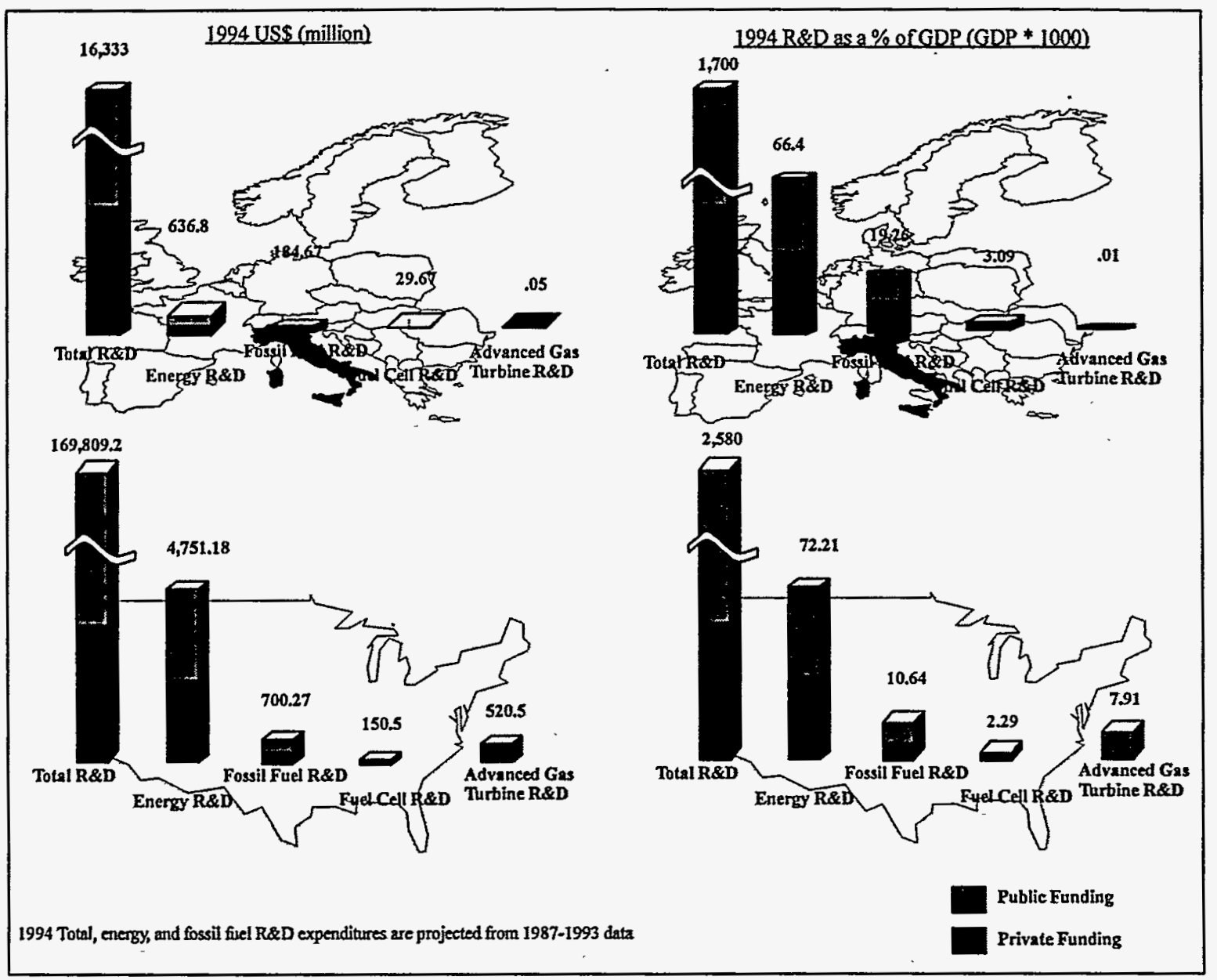

Figure 4.16. Italian R\&D Expenditures

\subsubsection{R\&D Expenditures}

Italian R\&D expenditures were estimated to total US\$16 billion in 1994 (see Figure 4.16). Italy has one of the largest R\&D programs in Europe but does not receive funding 
competitive with U.S. levels. The Italian R\&D program received increasingly higher levels of U.S. R\&D funding over 1988-1992, a average annual rate of change of $12.7 \%$. Only the $R \& D$ budget of Finland increased at a greater annual rate. Italy has a low level of R\&D expenditures as a percēntage of GDP (1.7\%). The strong increases in R\&D funding reflect an interest in maintaining an R\&D budget relative to GDP that is competitive with other leading European countries, Japan, and the U.S. Public R\&D support has totaled slightly more than private support over the past few years. Energy R\&D funding in Italy decreased rapidly over 1988-1992. The average annual rate of change in Energy R\&D was $-14 \%$ over that time. Italian energy R\&D expenditures as a percentage of GDP were among the lowest of the selected countries. Fossil fuel R\&D expenditures were determined to be approximately $29 \%$ of total energy R\&D expenditures. Italy allocated US $\$ 185$ million to fossil fuel R\&D, the fourth highest of the selected countries; as a percentage of total R\&D, only Canada and Belgium allocated more funding. Fuel cell R\&D funding in Italy was estimated at US $\$ 29.7$ million in 1994. Italy was estimated to have the second largest fuel cell R\&D program in Europe and the fifth largest of the selected countries. Advanced gas turbine R\&D in Italy was estimated as negligible.

\subsubsection{R\&D Organizational Structure}

R\&D funding in Italy comes from five federal sources (Ministry for Universities and Scientific and Technological Research, Inter-Ministerial Committee on Economic Planning, Ministry of Industry, and Ministry of Environment, and various other ministries), as well as private industry. Following are descriptions of the responsibilities of the four primary federal sources:

- Ministry for Universities and Scientific and Technological Research: Plans and coordinates funding for universities; Italian National Agency for New Technology, Energy, and the Environment; National Institute of Nuclear Physics; National Research Council; Italian Space Agency; and the Directorate of Nuclear Safety and Health Protection. Defines research priorities, oversees the university system, supervises public research establishments, and directs industrial research efforts through other government agencies.

-Inter-Ministerial Committee on Economic Planning. Plans and coordinates R\&D funding for the ENEA, National Institute of Nuclear Physics, and National Research Council. Administers broad policy on all of research and approves research budgets. Coordinates research between agencies.

- Ministry of Industry. Provides funding for the ENEA.

- Ministry of Environment. Provides funding for the ENEA. Coordinates Italian and EU environmental policy and centralizes regional environmental policies.

Performers of R\&D in Italy include private industry; universities; National Agency for New Technology, Energy, and the Environment; National Institute of Nuclear Physics; National 
Research Council; Italian Space Agency; National Electricity Agency; Higher Institute of Health, and Directorate of Nuclear Safety and Health Protection.

\subsubsection{Energy R\&D Sources of Electricity and Electricity}

Figure 4.17 shows the breakdown of energy R\&D and electricity generation for Italy. The country concentrated the highest percentage of its total energy R\&D funding on fossil fuels $(29 \%)$, and nuclear technologies (29\%). Overall, the division between energy areas was

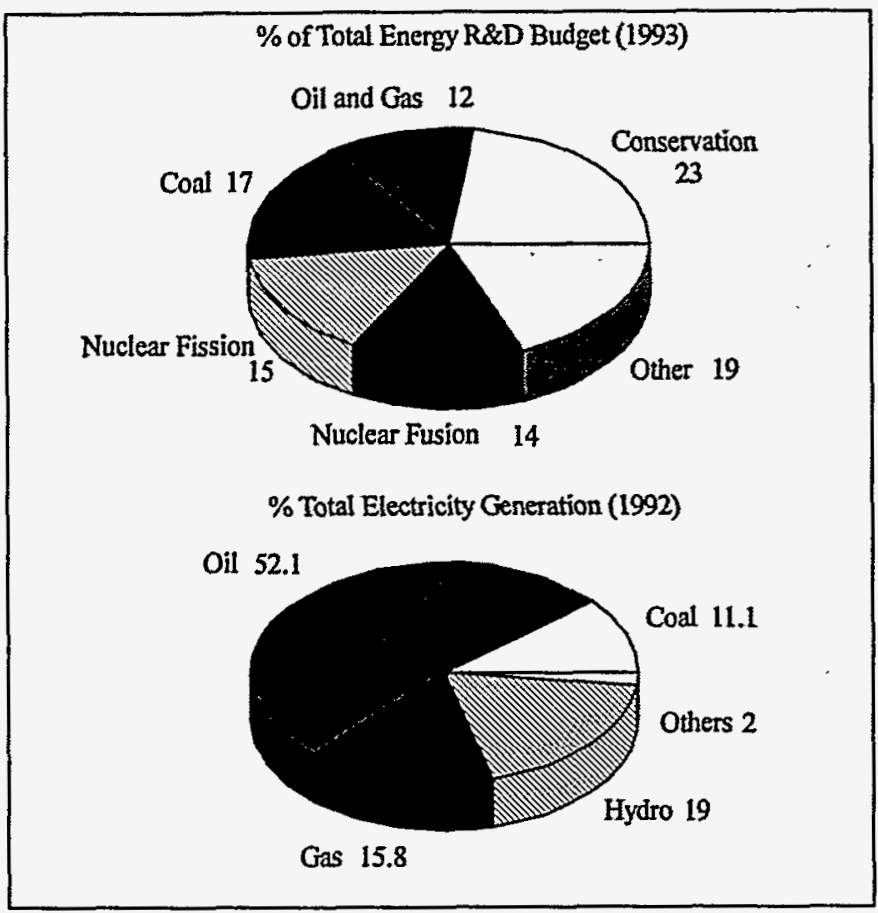

Figure 4.17. Breakdown of Italian Energy R\&D and Electricity Generation somewhat flat. The lowest

percentage of energy funding (12\%) was oil and gas, while the highest percentage (23\%) was conservation and renewables, which focused on hydroelectricity, solar, wind power, biomass, superconductors, fuel cells, and magneto-hydrodynamic conversion. Fossil fuel R\&D concentrated on advanced coal pretreatment methods, gasification technology, fluidized bed technology, drilling technology, transport and storage, refinery technologies, and higher quality oil products. Nuclear R\&D concentrated on safety and environmental protection and the RFX and Ignitor machines used in fusion research.

Electricity generation in Italy is highly dependent on fossil fuels.

Almost $80 \%$ of the country's total electrical generation is from oil, gas, and coal. Hydroelectric sources provide another $19 \%$ of the total, with only $2 \%$ coming from other sources. In 1988, Italian national policy called for abandonment of nuclear power and increased use of coal for electricity generation. Since then, Italy halted operation of its lightwater, nuclear power plants and all further construction of nuclear power plants.

\subsubsection{Fuel Cell and Advanced Gas Turbine Projects}

1994 fuel-cell R\&D expenditures were estimated at US\$29.7 million. The major private companies involved are Ansaldo, De Nora Permelec, and Fiat. The ENEA is responsible for the Italian fuel-cells R\&D program.

R\&D is being conducted on PEFC, PAFC, SOFC, MCFC, and AFC. (see Table 4.15). Of these, PEFC received the highest level of funding (US $\$ 20$ million). Fiat, Ansaldo, De Nora 
Permelec, and Technars support PEFC R\&D. The largest funder of fuel cell R\&D is Fiat, which has allocated US\$30 million for R\&D of PEFCs for transportation application. Fiat is to establish an R\&D facility that will investigate the proposed conversion of a 1,000vehicle/yr. electric/hybrid vehicle production facility to a PEFC-powered facility. The Italian government has allocated US\$19 million to PEFC R\&D over the next three years. MCFCs received the second highest level of funding in 1994. Ansaldo provided approximately US\$2.7 million for MCFC R\&D as did the federal government. Overall, ENEA sees much greater risk in SOFC technology; however, it believes that successful applications of MCFC technologies could pave the road for future SOFC implementation. The SOFC program includes a small program involving Eniricerche. Total funding for SOFC over the next few years should be less than US $\$ 1.2$ million/yr. Milan is home to the largest PAFC demonstration in the Europe (1.3 MW). This project involves ENEA, AEM (energy utility in Milan), and Ansaldo. In addition, Eniricerche and Acoser (gas utility in Bologna), both operate PAFC stacks. Future government funding for PAFC R\&D will be devoted to the Milan project and is expected not to exceed US $\$ 0.7 \mathrm{million} / \mathrm{yr}$. Ansaldo is contributing an electric drive system in the bus demonstration project.

Table 4.15. Fuel Cell Project List for Italy

\begin{tabular}{|c|c|c|c|c|}
\hline Project & \begin{tabular}{|l} 
Funding \\
Source
\end{tabular} & Performer & Dates & $\begin{array}{l}\text { Funding Level } \\
\text { USS (million) }\end{array}$ \\
\hline MCFC & $\begin{array}{l}\text { Italian } \\
\text { Government } \\
\text { (ENEA) }\end{array}$ & ENEA & 1994-1996 & 8.1 \\
\hline MCFC & \begin{tabular}{|l} 
Private \\
Industry \\
(Ansaldo, \\
CISE)
\end{tabular} & $\mathrm{NA}$ & \begin{tabular}{|c|}
$1994-1996$ \\
\end{tabular} & 8.1 \\
\hline SOFC, PAFC & $\begin{array}{l}\text { Government } \\
\text { (ENEA) }\end{array}$ & ENEA & 1994-1996 & .9 \\
\hline SOFC, PAFC & Private & $\mathrm{NA}$ & 1994-1996 & .9 \\
\hline PEFC & $\begin{array}{l}\text { Government } \\
\text { (Ministry of } \\
\text { Industry) }\end{array}$ & $\mathrm{NA}$ & 1994-1996 & 19 \\
\hline PEFC & $\begin{array}{l}\text { DeNora } \\
\text { Fiat/Avio } \\
\text { Ansaldo } \\
\text { Tecnars } \\
\end{array}$ & NA & \begin{tabular}{|l|}
$1994-1996$ \\
\end{tabular} & $\begin{array}{l}2 / \mathrm{yr} . \\
30 \\
\text { NA } \\
\text { NA }\end{array}$ \\
\hline
\end{tabular}


Table 4.15 Continued

\begin{tabular}{|l|l|l|l|l|}
\hline Project & $\begin{array}{l}\text { Funding } \\
\text { Source }\end{array}$ & Performer & Dates & $\begin{array}{l}\text { Funding Level } \\
\text { US\$ (million) }\end{array}$ \\
\hline AFC (Elenco) & Ansaldo & Ansaldo & 1991 -present & NA \\
\hline PAFC & Eniricerche & Eniricerche & NA & NA \\
\hline PAFC & ACOSER & ACOSER & NA & NA \\
\hline PAFC & CLC & CLC & NA & NA \\
\hline PAFC & ENEA & NA & $1990-1994$ & 16 \\
\hline
\end{tabular}

1994 advanced gas turbine R\&D funding was estimated at US $\$ 50,000$. The only identified government support for gas turbine R\&D was a US $\$ 50,000$ contribution from ENEL to the Cooperative Aeroderivative Gas Turbine Project. ENI and Italgas indicated no support for advanced gas turbine R\&D. Overall, Italy's government does not support advanced gas turbine R\&D but follows advances made in industry. Nuovo Pignone was estimated to have allocated US\$3-5 million/yr. on gas turbine R\&D during 1991 and 1992; however, due to the recent purchase of Nuovo Pignone by General Electric (U.S.), all current funding for R\&D was attributed to the total GE expenditures.

Table 4.16. Advanced Gas Turbine Project List for Italy

\begin{tabular}{|l|l|l|l|l|}
\hline Project & $\begin{array}{l}\text { Funding } \\
\text { Source }\end{array}$ & Performer & Dates & $\begin{array}{l}\text { Funding Level } \\
\text { US\$ (million) }\end{array}$ \\
\hline Aeroderivative & ENEL (CAGT) & CAGT & 1994 & .05 \\
\hline Various & Nuovo Pignone & Various & $\begin{array}{l}1992 \\
1991\end{array}$ & $\begin{array}{l}4.85^{*} \\
3^{*}\end{array}$ \\
\hline
\end{tabular}

* Estimated levels of expenditures 


\subsection{Japan}

Japan is the world's leading funder of energy R\&D, allocating more than 30 US\$ billion in 1994 (see Figure 4.18). Energy R\&D budget has grown at an average annual rate of 5.7\% during 1989-1993. Historically, private industry has provided more than $80 \%$ of the country's total R\&D funding. The Japanese have the world's largest budget for fuel cells $\mathrm{R} \& \mathrm{D}$ and one of the top five budgets for advanced gas turbine R\&D. The world's largest phosphoric acid fuel cell power plant $(11 \mathrm{MW})$ was installed at the Tokyo Electric Power Company in March 1991.

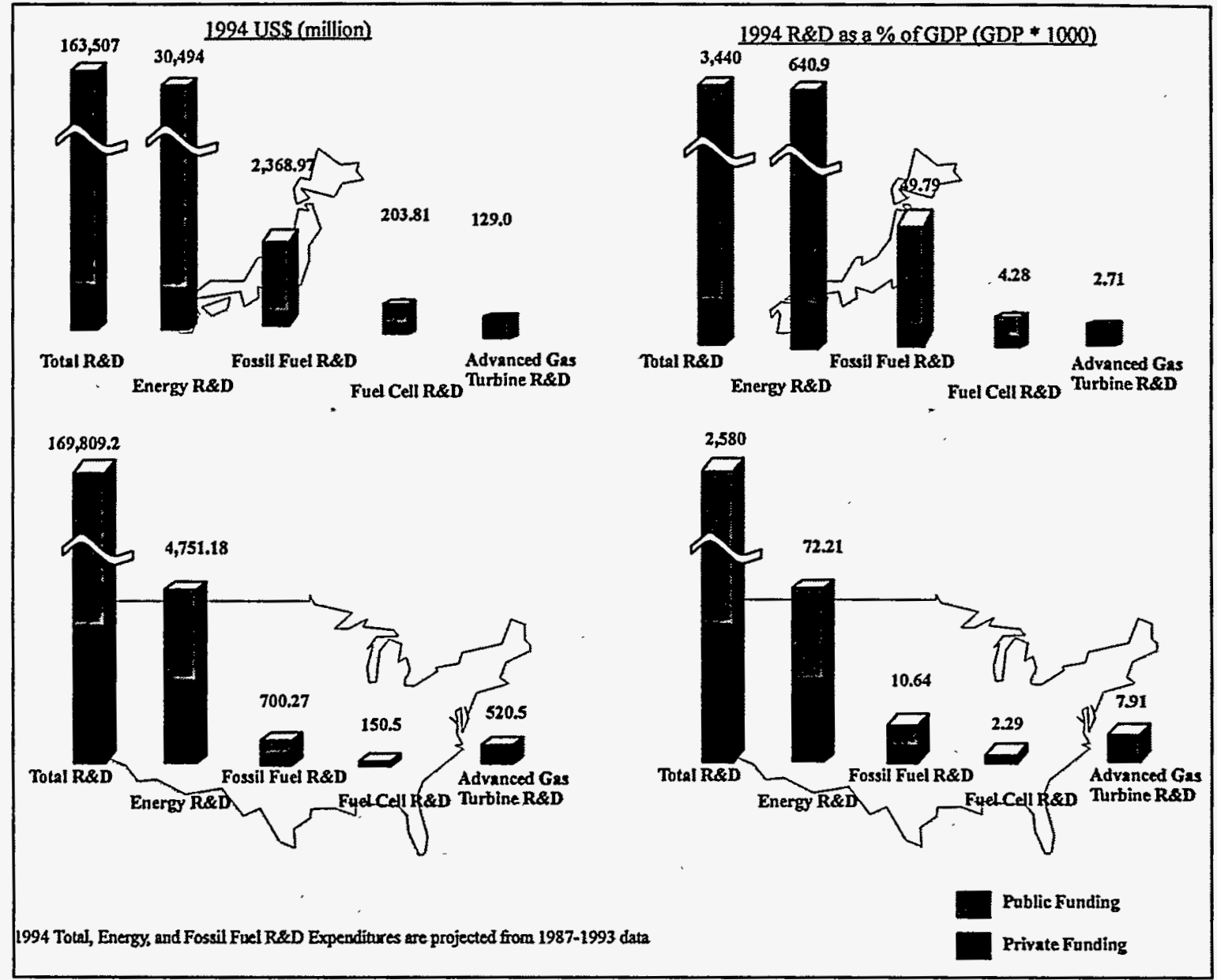

Figure 4.18. Japanese R\&D Expenditures 


\subsubsection{R\&D Expenditures}

Japanese R\&D expenditures accounted for close to one third of the total R\&D expenditures of the selected countries. Only the U.S. allocated more. As a percentage of GDP, the Japanese provided a higher level of funding than the U.S. The Japanese private sector contributed $83 \%$ of the country's total R\&D funding, the highest of the selected countries. Japan allocated close to US $\$ 30.5$ billion on energy R\&D funding, more than six times the level of the U.S., the next highest country. Approximately $18.7 \%$ of the total Japanese R\&D expenditures were allocated to energy R\&D, compared to $2.8 \%$ in the U.S. Japanese energy R\&D expenditures accounted for $73 \%$ of the total energy R\&D expenditures of the selected countries. Japanese energy R\&D expenditures increased at an average annual rate of $5.7 \%$ from 1989 to 1993. In contrast, U.S. energy R\&D budgets during 1990-1993 decreased at an annual rate of $4.3 \%$. As a percentage of GDP, Japanese energy R\&D expenditures were more than double the next highest country, Finland, and were more than nine times the U.S. level. Fossil fuel R\&D in Japan accounted for $1.5 \%$ of the total Japanese R\&D budget.

Approximately US $\$ 2.4$ billion was allocated for fossil fuel R\&D in Japan. In comparison, the U.S. allocated approximately US\$ 700 million on fossil fuel R\&D. The Japanese fossil fuel R\&D budget grew at an average annual rate of $1.5 \%$ over the past few years. 1994 fuel cell R\&D expenditures in Japan were estimated at more than US\$200 million. A higher than average Japanese proportion of total $R \& D$ funding was provided by the country's government for fuel cells, $36 \%$ of the total. Advanced gas turbine R\&D was estimated to total US $\$ 129$ million. Private sources provided most of the advanced gas turbine R\&D funding.

\subsubsection{R\&D Organizational Structure}

R\&D funding in Japan is provided by both the pubic and private sectors. Japanese private industry typically provides much higher levels of R\&D funding than does the federal government. Within the federal government the following agencies provide funding and policy implementation for science and technology R\&D.

- Ministry of Education, Science, and Culture. Provides approximately $50 \%$ of the total government funding for science and technology R\&D. Provides funding for basic and applied research at national universities, as well as for maintenance of science and engineering departments.

- Ministry of International Trade and Industry (MITI). Administers 13\% of the total government science and technology R\&D funds. The Agency for Industrial Science and Technology(AIST), internal to MITI, promotes industrial science and technology as the primary mission of MITI. AIST operates a variety of government research laboratories with a combined budget of approximately US\$ 1 billion. Various research programs are administered through AIST, including, the Sunshine Project on new energy technologies, the New Sunshine Project (formerly the Moonlight project), the Basic Technologies for 
Future Industries R\&D program, the Large Scale Project, and the Medical and Welfare Equipment Technology R\&D program. All federal fuel cell R\&D funding is administered by MHTI.

- Science and Technology Agency. Responsible for $26 \%$ of the total federal science and technology R\&D funds. Provides overall administration of all federal R\&D programs, except for the Ministry of Education, Science, and Culture. Nuclear energy and the National Space Agency are heavily supported by the Science and Technology Agency.

- Defense Agency. Administers 5\% of the total federal science and technological funds. Coordinates major development projects with the private sector through its Technical Research and Development Institute. Many of the projects involve collaboration with counterparts in the U.S. industry-military complex.

\subsubsection{Energy R\&D and Sources of Electricity}

Nuclear fusion is the focus of Japanese energy R\&D expenditures. The Japanese government allocated close to US\$ 3.2 billion on nuclear fusion R\&D in 1993 (private company contributions for nuclear fusion were not available). Alone, the Japanese government's total expenditures on nuclear fusion $R \& D$ were more than the combined total energy R\&D expenditures of the governments of all the selected countries with the exception of the U.S. Nuclear fusion and fission combined accounted for close to $85 \%$ of the total Japanese energy R\&D budget. Nuclear supporting technology received more than US\$ 800 million in 1993. Fossil fuel R\&D received close to US\$ 2.4 billion the same year. The areas of refining transportation (oil and gas), coal combustion, and coal conversion received the majority of federal fossil-fuel R\&D funding.

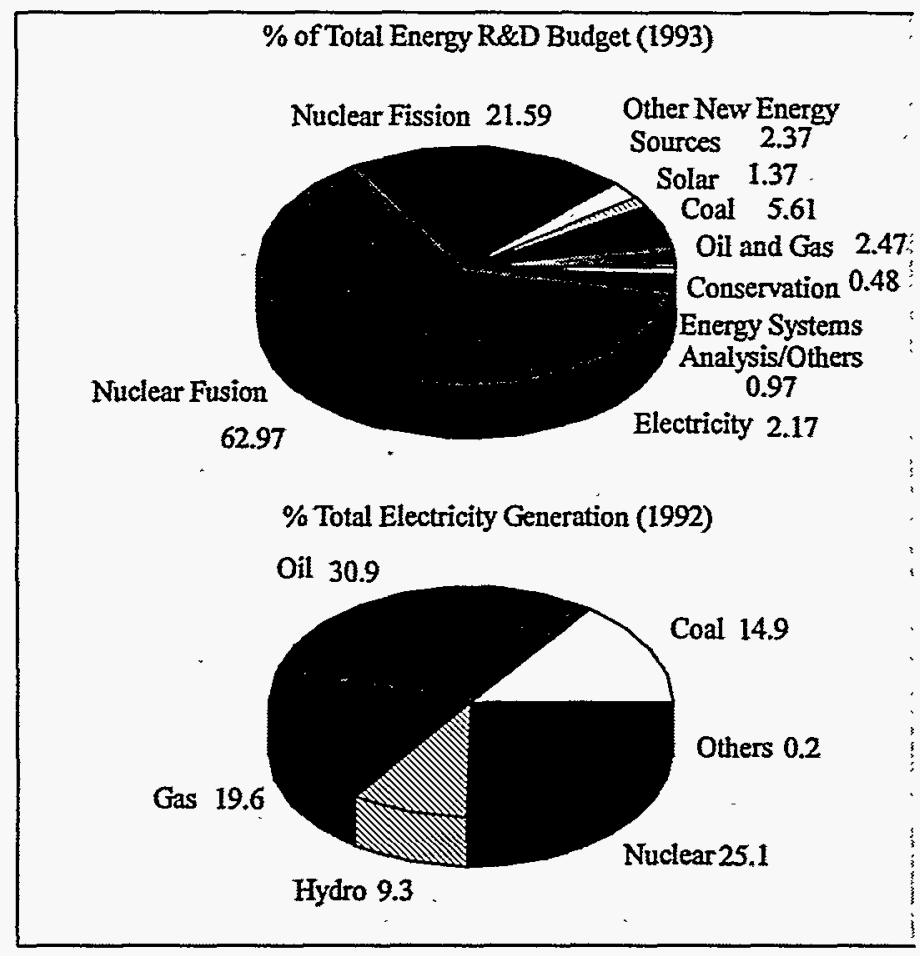

Figure 4.19 Breakdown of Japanese Energy R\&D and Electricity Generation 
Japan generates electricity through the use of all the traditional sources. Oil, coal, gas, nuclear, and hydroelectric technologies all provided significant percentages of the total generated electricity. In the past, oil was the dominant fuel generating electricity. In 1973, $73 \%$ of the total generated electricity was from oil. Presently, only $31 \%$ of the electricity in Japan is generated from oil (see Figure 4.19). OECD projections indicate that the Japan will continue to decrease its reliance on oil and will slowly increase use of nuclear energy to generate electricity. It is projected that, in 2010 , almost $40 \%$ of the total generated electricity will be by nuclear energy technology. Solar energy is also projected to slowly increase in the overall Japanese generation of electricity.

\subsubsection{Fuel Cell and Advanced Gas Turbine Projects}

1994 fuel cell R\&D expenditures in Japan were estimated at US\$204 million. The primary sources of fuel cell R\&D funding are the Japanese government, utilities, and private companies.

The Japanese government supports fuel cell R\&D through MITI, which has two primary mechanisms for funding fuel cell R\&D: (1) the New Sunshine program, administered by the New Energy and Industrial Technology Development Organization, and (2) the Agency of Natural Resources and Energy. Forty-three fuel cell projects were identified within the NEDO-administered program (NEDO, 1993). The New Sunshine program is active in the R\&D of three types of fuel cells: MCFC, SOFC, and PEFC. The program's MCFC objectives for 1994 were development of high performance, large scale MCFC cell and stacks; development of a $1000 \mathrm{~kW}$ class generation system; research of stack materials; and development of application technologies for coal gases. SOFC development in 1994 concentrated on development of basic technologies intending to complete a total SOFC fuel cell generating system, research on the fundamental structure of a several-kW stack module, and materials and system technologies. PEFC R\&D aimed at development of a generating system. R\&D projects included research on the fundamental structure of a 1-kW stack module, and a system study of reforming technologies, $\mathrm{CO}$ removal technologies, and optimizing the structure of a total system. Prior to 1991, New Sunshine funding was provided for PAFC R\&D; subsequently PAFC funding was discontinued. In 1994, the highest level of New Sunshine funding was allocated to MCFC R\&D, which was funded at approximately US\$ 44 million in 1994. SOFC R\&D funding totaled US\$ 4 million and PEFC R\&D funding totaled US $\$ 2.3$ million. The Agency of Natural Resources and Energy funded various PAFC plants, a fuel-cell field test, and development of reforming systems for

hydrogen production. PAFC funding by the Agency of Natural Resources and Energy totaled US\$ 11.3 million over three demonstration projects. In each of these projects, $50 \%$ of funding was provided by electric and gas utilities, with the remaining provided by the Agency. In addition, the Agency supported a fuel-cell field test at $50 \%$ of the total cost, (a contribution of US\$ 5.25 million) and development of reforming systems for hydrogen production at $100 \%$ of the total cost (a contribution of US $\$ 900,000$ ). 
Japan has three of the ten largest electric utilities in the world. These include Tokyo Electric Power Company (TEPCO), Kansai Electric Power Company, Chubu Electric Power Company, and Tohoku Electric Power Company. Each of these is involved in the R\&D of fuel cells. Tokyo Gas Company, a gas utility, provides additional funding for fuel-cell R\&D. All of these utilities consider fuel-cell R\&D funding information proprietary; therefore, fuelcell R\&D funding is estimated.

1993 sales for TEPCO totaled approximately US $\$ 47$ billion. TEPCO maintains a large inhouse $R \& D$ program. At least $65 \mathrm{R} \& D$ projects were identified for TEPCO; these projects range in focus from neural networks to development of superconductors. TEPCO's R\&D program had four primary objectives: (1) stable power supply and social safety measures, (2) measures to realize a recycling society, (3) reduced operation costs and increased work efficiency, and (4) improved service to meet the needs of more sophisticated and diversified customers. To meet these objectives, TEPCO's R\&D program focused on the following areas: nuclear power technologies, integrated coal gasification combined cycle and environmental protection, new energies (focus on fuel-cells), technologies to support urbanization and information intensive society, technologies to support higher efficiency and safety, and meeting customer needs. At least four TEPCO-funded fuel-cell R\&D projects were identified. Fuel cells are identified as the "hero" of new energies. The most impressive TEPCO funded project is an 11-MW PAFC plant put into operation in March 1991. Prior to the 11-MW plant, TEPCO had installed the largest plant in the PAFC plant in the world in April 1983 at $4.5 \mathrm{MW}$. TEPCO considers the PAFC to be at the practical use stage. The MCFC is in the operational research stage, generating at the $100-\mathrm{kW}$ level. The SOFC is in the basic research stage, $1-\mathrm{kW}$ stacks. Due to the high level of importance TEPCO places on fuel cells, the large size of its R\&D program and fuel cell projects, and the tremendous monetary resources available, it was estimated that the total fuel cell $R \& D$ expenditures were approximately US\$ $38 \mathrm{million} / \mathrm{yr}$.

Kansai electric power company had 1993 sales of approximately US\$ 24 billion in 1994. Kansai promotes developing and introducing innovative technology. The company indicated four areas of R\&D concentration: development of technologies to help facilitate the establishment of new power plants, development of technologies to ensure safety and reliability, development of technologies to improve overall energy efficiency, and development of technologies beneficial to both the company and the community. Kansai operates a combined power generation system with a phosphoric acid fuel cell at its technical research center. Total fuel-cell $R \& D$ funding by Kansai was estimated at approximately US\$ 19 million.

Chubu and Tohoku Electric power companies had sales of approximately US\$ 20 billion and US\$ 3 billion, respectively. Chubu performs much of its R\&D at its electric power research and development center. Chubu has achieved world-record success in generating electricity with a SOFC and a PAFC. The company was estimated to allocate close to US\$ 16 million on fuel cell R\&D. Tohoku is involved in demonstrating a PAFC stack. Tohoku R\&D expenditures were estimated at slightly under US\$ 1 million/yr. 
Fuel Cell R\&D projects identified for Tokyo Gas Company, Ltd.include; development of 50$\mathrm{kW}$ and 100-kW PAFCs, development of 200-kW PAFCs, development of a 100-kW-class cogeneration system, conduction of tests on SOFCs manufactured by Westinghouse, and development of new desulfurization and reforming processes for fuel cells. The total estimated fuel cell R\&D expenditures for Tokyo Gas was approximately US\$11 million.

The Phosphoric Acid Fuel Cell Research Association (PAFCRA) of Japan includes the electric and gas utilities mentioned above as well as smaller utilities and NEDO. PAFCRA indicated funding of approximately US\$120 million over 1991-1996. NEDO provided 50\% of the total funding with the balance provided by member utilities. The US $\$ 120$ million from PAFCRA was not included in the total fuel-cell R\&D budget calculations of Japan. Funding for this program was assumed to be budgeted by member utilities and NEDO.

Private Japanese companies involved in fuel cell R\&D include Mitsubishi, Fuji, Hitachi, Toshiba, Sanyo, and IHI (see Table 4.17). These six companies are all multi-billion dollar companies. Hitachi had 1993 sales of close to 75 billion US\$. Hitachi and IHI have both been involved with the MCFC development program of MITI. Fuji is a world leader in the research, development, and manufacturing of PAFC stacks and is a member of the Moonlight project of MITI. Toshiba is also a member of the Moonlight project. Mitsubishi operated a 30-kW unit and a 100-kW unit produced by ERC (U.S.) in 1993 and performed more than 20,000 hours of testing on single cells. Sanyo, in conjunction with ERC (U.S.), performs R\&D on small phosphoric acid fuel cell systems for consumer applications. These companies were estimated to allocate between US\$3-16 million/yr. on fuel cell R\&D.

Table 4.17. Fuel Cell Project List for Japan

\begin{tabular}{|l|l|l|l|l|}
\hline Project & $\begin{array}{l}\text { Funding } \\
\text { Source }\end{array}$ & Performer & Dates & $\begin{array}{l}\text { Funding Level } \\
\text { US\$ (million) }\end{array}$ \\
\hline Various & $\begin{array}{l}\text { Federal } \\
\text { Government }\end{array}$ & Various & 1994 & 68 \\
\hline Various & $\begin{array}{l}\text { Tokyo Electric } \\
\text { Power } \\
\text { Company }\end{array}$ & Various & 1994 & $37.9^{*}$ \\
\hline Various & $\begin{array}{l}\text { Kansai Electric } \\
\text { Power } \\
\text { Company }\end{array}$ & Various & 1994 & $19^{*}$ \\
\hline Various & $\begin{array}{l}\text { Chubu Electric } \\
\text { Power } \\
\text { Company }\end{array}$ & Various & 1994 & $15.7^{*}$ \\
\hline
\end{tabular}


Table 4.17. Continued.

\begin{tabular}{|c|c|c|c|c|}
\hline Project & $\begin{array}{l}\text { Funding } \\
\text { Source }\end{array}$ & Performer & Dates & $\begin{array}{l}\text { Funding Level } \\
\text { US\$ (million) }\end{array}$ \\
\hline Various & $\begin{array}{l}\text { Tohoku } \\
\text { Electric Power } \\
\text { Company }\end{array}$ & Various & 1994 & $0.7^{*}$ \\
\hline $\begin{array}{l}\text { PAFC } \\
\text { Research } \\
\text { Association }\end{array}$ & Members & Various & $1991-1996$ & 120 \\
\hline Various & Tokyo Gas & Various & 1994 & $10.9^{*}$ \\
\hline Small PAFC & Sanyo & Sanyo & 1993-1994 & $\overline{\mathrm{NA}}$ \\
\hline Various & Toshiba & Toshiba & 1994 & $\overline{\mathrm{NA}}$ \\
\hline Various & IHI & IHI & 1994 & $15.7^{*}$ \\
\hline Various & Fuji & $\overline{\text { Fuji }}$ & 1994 & $15.7^{*}$ \\
\hline Various & Hitachi & Hitachi & 1994 & $15.7^{*}$ \\
\hline $\begin{array}{l}\text { Operation and } \\
\text { testing of } \\
\text { PAFC }\end{array}$ & Mitsubishi & Various & 1993 & $3.6^{*}$ \\
\hline
\end{tabular}

* Estimated funding levels for all fuel cell R\&D activities.

Advanced gas turbine R\&D funding was estimated at US\$129 million in 1994. Advanced gas turbine R\&D in Japan was primarily funded by private industry; however government funds advanced gas turbine R\&D under the New Sunshine program. The total gas turbine funding provided by the Japanese government was US\$23.4 million in 1994. Private advanced gas turbine $R \& D$ funding came from similar sources as fuel cell $R \& D$ funding. Overall, electric and gas utilities and a select number of private companies provided the bulk of funding for advanced gas turbine R\&D, whose goal was development of high-temperature gas turbines, use of ceramics in gas turbines, and development of gas turbines for use with coal gas. 
TEPCO, Tokyo Gas, and Tohoku Electric were all confirmed to have advanced gas turbine R\&D projects. TEPCO had at least two such projects, including an investigation into hightemperature ceramic gas turbines. Tokyo Gas indicated it had a project on development of ceramic gas engine systems and a project on development of a gas turbine system for cogeneration. Tohoku Electric has research on development of a $1500^{\circ} \mathrm{C}$ class high temperature gas turbine. The Tohoku study was conducted in conjunction with Mitsubishi, estimated expenditures of these companies are indicated in Table 4.18.

Mitsubishi, Hitachi, Kawasaki, IHI, and Toshiba were considered the primary private companies involved with gas turbine R\&D. Mitsubishi has a gas turbine development relationship with Westinghouse Electric Corporation and Fiat Avio S.p.A.. Kawasaki is involved in a joint venture with ABB. Hitachi sells the larger frame gas turbines of General Electric, (i.e. the PG5371 through the PG7221).

Kawasaki had sales of approximately US\$ 10 billion in 1994. The company established a joint venture with $A B B$ to manufacture and market new gas turbines. Kawasaki has constructed a gas-turbine research institute where it has started trial operation of equipment to be used for testing large gas turbines from $\mathrm{ABB}$ for power generation. Kawasaki developed a high-efficiency $6 \mathrm{MW}$ gas turbine, the PUC60, and recently completed a commercialization study for the turbine. It was estimated that Kawasaki allocated close to US\$ 40 million on gas turbine R\&D in 1994.

Mitsubishi had sales of approximately US\$ 30 billion in 1993. In conjunction with Westinghouse Electric and Fiat Avio, Mitsubishi developed the high-efficiency, hightemperature $701 \mathrm{~F}$ gas turbine. The $701 \mathrm{~F}$ offers high capacity, high efficiency, and low $\mathrm{NO}_{\mathrm{x}}$ and $\mathrm{CO}_{2}$ emmissions. Mitsubishi also committed time and resources to developing a computer-aided turbine design system. Mitsubishi's Takasago Research and Development Center has been engaged in intensive $R \& D$ in a variety of fields since 1908 . Fields involving gas turbine R\&D are turbomachinery; flow and heat transfer; and materials, strength, and chemistry. The estimated level of funding for gas turbine R\&D by Mitsubishi was US $\$ 3.6$ million.

Hitachi had sales of close to US\$75 billion in 1993 . The company manufactures and sells a class of gas turbines in the 10-27 MW range. In addition, Hitachi sells gas turbines developed by General Electric in the 26-160 MW range. Hitachi has a large R\&D program (the total 1992 budget for R\&D was US $\$ 4.3$ billion). Hitachi employs 18,000 people in 38 different laboratories within its $R \& D$ program. It was estimated that total advanced gas turbine R\&D expenditures by Hitachi were approximately US\$ 16 million.

IHI engaged in research, development, engineering and production of various types of aircraft engines and power ranges of land and marine gas turbines. IHI conducted R\&D in the following areas;

- Fan and low-pressure compressor modules for the five-nations collaborative turbofan V2500 program 
- Design and development of low-pressure turbine rotors and shafts in collaborative project with General Electric

- Component development and demonstrator engine integration for MITI's super/hypersonic propulsion system.

- R\&D of a $300 \mathrm{~kW}$ class ceramic gas turbine.

Funding levels for IHI's gas turbine R\&D program were not available.

Toshiba Corporation is a member of the Manufacturing Associates of General Electric for heavy duty gas turbines. Toshiba planned to construct test facilities for the large-capacity gas turbines, such as the 9FA and 7FA, and the test facilities in the West Turbine Works were scheduled for completion by the end of 1994. Toshiba has made an effort to develop the technology of the gas turbine (specifically, the development of dry low $\mathrm{NO}_{\mathrm{x}}$ combustion to meet environmental needs). Toshiba focuses on development of a $1,300^{\circ} \mathrm{C}$ class turbine that has low $\mathrm{NO}_{\mathrm{x}}$ emission levels. Toshiba is working in cooperation with TEPCO throughout this project. At the West Turbine Works in 1992, testing of a 15-MW high-temperature experimental gas turbine confirmed low $\mathrm{NO}_{\mathrm{X}}$ emission, combustion stability, and reliability.

Table 4.18 Advanced Gas Turbines Project List

\begin{tabular}{|c|c|c|c|c|}
\hline Project & \begin{tabular}{|l|} 
Funding \\
Source
\end{tabular} & Performer & Dates & $\begin{array}{l}\text { Funding Level } \\
\text { US\$ (million) }\end{array}$ \\
\hline $\begin{array}{l}\text { New Sunshine } \\
\text { Projects }\end{array}$ & $\begin{array}{l}\text { Federal } \\
\text { Government }\end{array}$ & Various & 1993 & 23.4 \\
\hline Various & Kawasaki & Various & $\begin{array}{l}1994 \\
1993 \\
1992\end{array}$ & $\begin{array}{l}38.9^{*} \\
29.4^{*} \\
25.6^{*}\end{array}$ \\
\hline Various & $\begin{array}{l}\text { Tokyo Electric } \\
\text { Power } \\
\text { Company }\end{array}$ & Various & $\begin{array}{l}1993 \\
1992\end{array}$ & $\begin{array}{l}37.9^{*} \\
37.5^{*}\end{array}$ \\
\hline Various & \begin{tabular}{|l|} 
Tohoku \\
Electric Power \\
Company
\end{tabular} & Various & $\begin{array}{l}1994 \\
1993\end{array}$ & $\begin{array}{l}0.7^{*} \\
0.6^{*}\end{array}$ \\
\hline
\end{tabular}


Table 4.18. Continued.

\begin{tabular}{|l|l|l|l|l|}
\hline Project & $\begin{array}{l}\text { Funding } \\
\text { Source }\end{array}$ & Performer & Dates & $\begin{array}{l}\text { Funding Level } \\
\text { US\$ (million) }\end{array}$ \\
\hline Various & $\begin{array}{l}\text { Tokyo Gas } \\
\text { Company }\end{array}$ & Various & 1994 & 8.8 \\
& & 1993 & 8.1 \\
\hline Various & Hitachi & Various & 1993 & $15.7^{*}$ \\
\hline Various & IHI & Various & 1993 & NA \\
\hline Various & Toshiba & Various & 1993 & NA \\
\hline Various & Mitsubishi & Various & 1993 & $3.6^{*}$ \\
& & & 1992 & \\
\hline
\end{tabular}

${ }^{*}$ Estimated levels of expenditures 


\subsection{Netherlands}

The Netherlands consistently reduced its energy and fossil fuel R\&D budget over the past several years. The energy R\&D budget has decreased at a rate of 4.7\% during 1990-1993. With over $25 \%$ of energy R\&D expenditures devoted to energy conservation, fuel cells are a prime target for government funding. The Netherlands' estimated level of fuel-cell R\&D funding was US\$ 16.2 million. Approximately US\$ 5 million was allocated to advanced gas turbine R\&D in 1994. Although the Netherlands is highly dependent on gas for electricity no major gas turbine manufacturers are located in the country. As a result, the expenditures on advanced gas turbine R\&D are minimal compared to the private-sector expenditures in other selected countries.

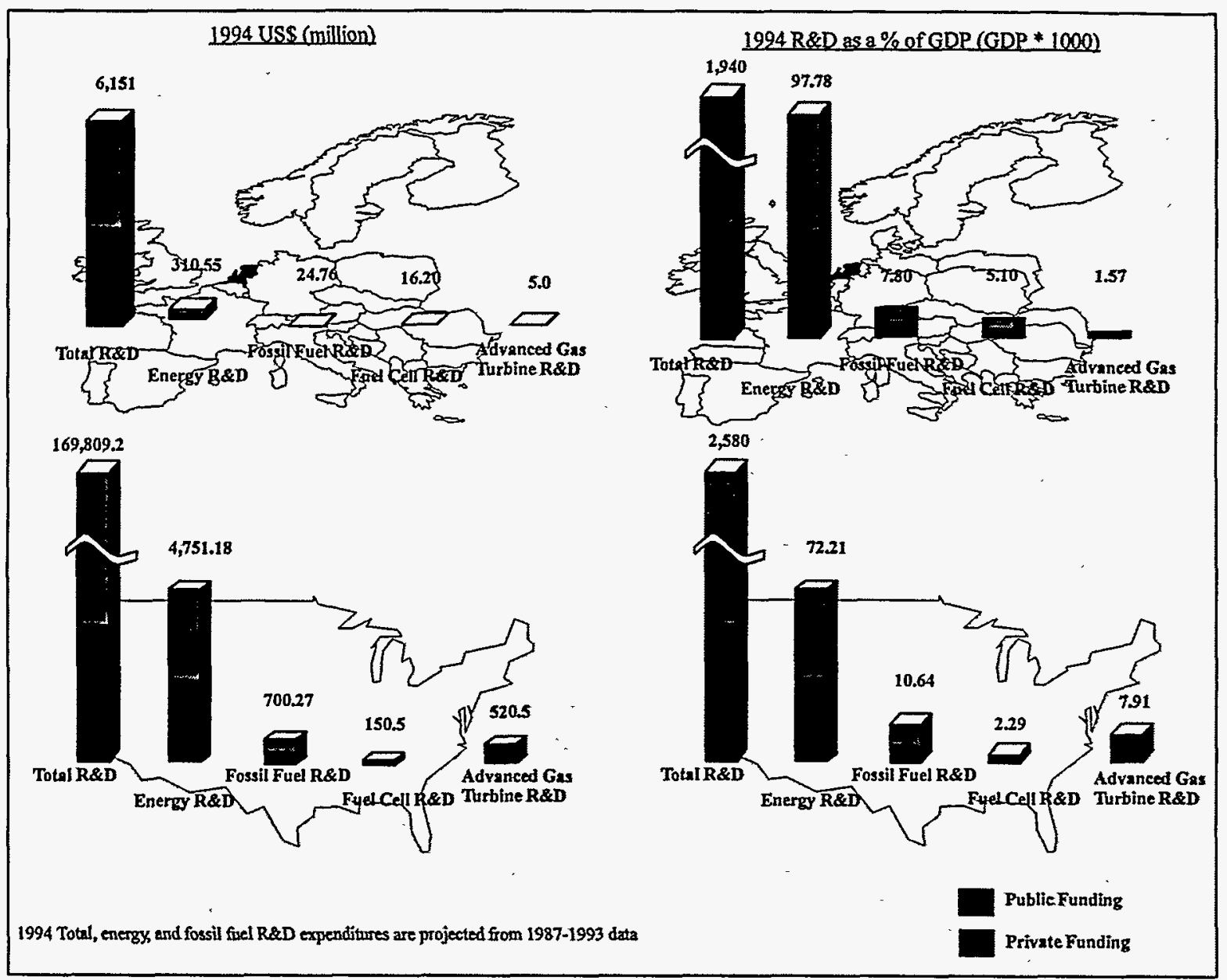

Figure 4.20. Dutch R\&D Expenditures 


\subsubsection{R\&D Expenditures}

Total R\&D expenditures in the Netherlands were estimated at slightly more than US\$ 6 billion for 1994 (see Figure 4.20). The Netherlands does not have a large R\&D budget relative to its GDP. The ratio of total R\&D to GDP was $1.94 \%$, lower than the U.S. ratio of $2.58 \%$. The average annual rate of change in the total R\&D budget of the Netherlands was $2.3 \%$ during $1986-1990$. The private sector funds $52 \%$ of the total R\&D. The average annual rate of change in energy R\&D was $-4.7 \%$ over $1990-1993$. The energy R\&D budget decreased from US\$376 million to US\$ 311 million over this period. Fossil fuel R\&D also received less funding over the past several years. The average annual rate of change in fossil fuel R\&D funding was $-3.3 \%$ over $1990-1993$. The estimated fossil fuel R\&D budget of close to US\$ 25 million was the third lowest of the selected countries. The fuel-cell R\&D budget was, however, one of the highest in Europe. It was estimated that approximately US\$ 16 million was spent on fuel-cell R\&D during 1994. Germany and Italy were the only European countries to allocate more. Canada and Denmark were the only selected countries with a higher ratio of fuel-cell R\&D to GDP than the Netherlands. Advanced gas turbine R\&D in the Netherlands was approximately US $\$ 5$ million. Approximately $60 \%$ of the total advanced gas turbine R\&D was provided by the country's government.

\subsubsection{R\&D Organizational Structure}

The primary science and technology policymaking bodies are the Ministry of Economic Affairs which formulates technological policy through integration with industry, education, and the research community and the Ministry of Education and Science which sets science policy. Other ministries and the private sector play smaller roles in setting science policy.

Various agencies, organizations, and programs important in the structure of the Netherlands R\&D community include:

- The Netherlands Organization for Scientific Research. An official government research organization that promotes applied research in construction, energy and the environment, industrial technology, health, nutrition, and defense.

- The Technology Foundation. Provides funding for R\&D at universities that have application in business, government, and other science fields. Stresses interaction of researchers and users through meetings that ensures users' needs are being met.

- Innovation Oriented Research Programs. Programs funded by the Ministry of Economic Affairs include biotechnology, construction, aids for the handicapped, membrane technology, polymers, ceramics, opto-electrics, and metals. 
- Government Technological Institutes. Receive funding from private sources and from the Ministry of Economic Affairs. These institutes include the Netherlands Center for Energy Research, the Netherlands Maritime Research Institute, the National Aerospace Laboratory, and the Hydraulic Laboratory Foundation. The Netherlands Center for Energy Research conducts R\&D on fuel cells.

- Netherlands Agency for Energy and the Environment. Coordinates and manages energy technology projects conducted by universities, research institutions, and the private sector. Primary agency for implementation of R\&D policy.

\subsubsection{Energy R\&D and Sources of Electricity}

The Netherlands provides more R\&D funding for energy conservation than for any other area of energy R\&D. A little more than one fourth of the total energy R\&D is committed to energy conservation. Within the energy conservation subgroup, the Netherlands concentrated on industrial energy conservation, followed by transportation energy conservation. Nuclear

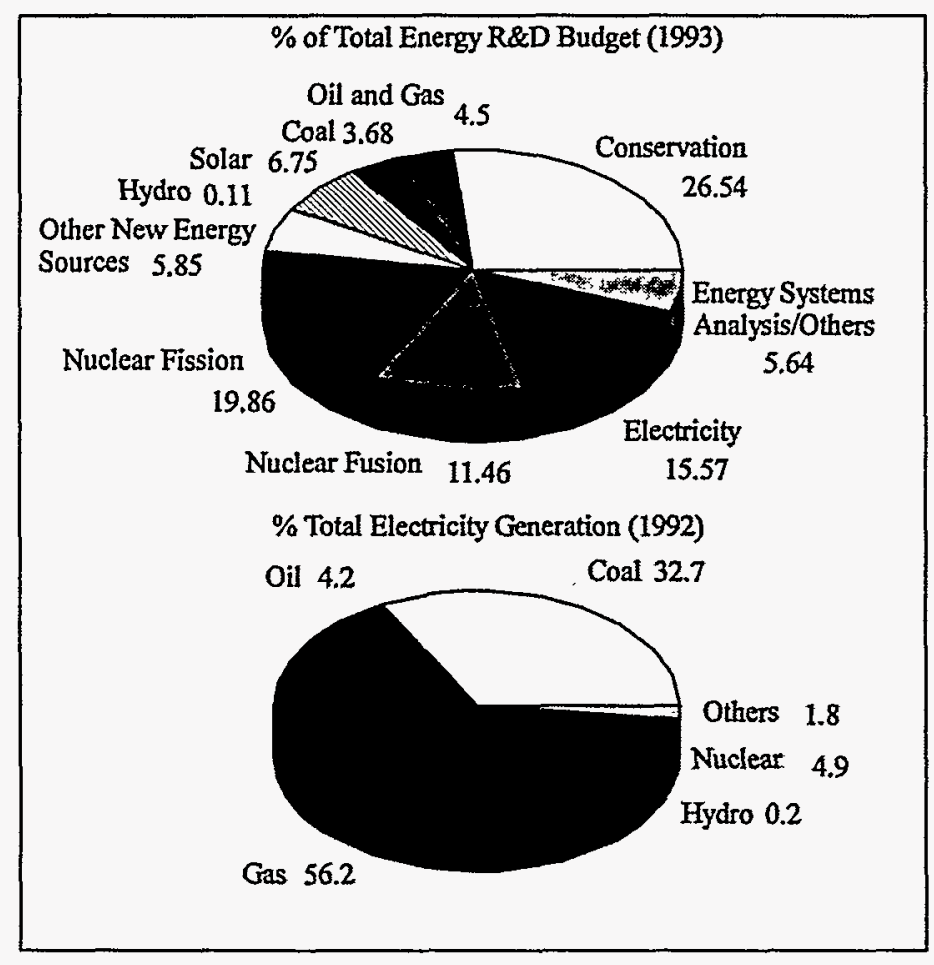

Figure 4.21 Breakdown of Dutch related $\mathrm{R} \& \mathrm{D}$ received close to $32 \%$ of the total energy R\&D budget in 1993 (see Figure 4.21). Nuclear fission supporting technology received $11 \%$ of the total energy $\mathrm{R} \& \mathrm{D}$ budget, nuclear fusion received $11.5 \%$, and fossil-fuel R\&D commanded $8.2 \%$. Oil and gas received $4.5 \%$ and coal received $3.7 \%$. Enhanced oil and gas recovery received $3.6 \%$ of the total energy R\&D budget.

The Netherlands generated more than $90 \%$ of its total electricity through the use of fossil fuels in 1992. Nuclear and hydro were used to generate approximately $5 \%$ of total electricity. Future projections indicate that the Netherlands will gradually replace nuclear energy with solar/wind power and the burning of non-coal solid fuels. In the year 2010 , the Netherlands is projected to use nuclear energy for less than $0.1 \%$ of its total electricity generation. 


\subsubsection{Fuel Cell and Advanced Gas Turbine Projects}

1994 Fuel cell R\&D funding was estimated at US\$16.2 million. Fuel-cell funding information was provided directly by the Government of the Netherlands. The Government of the Netherlands and other sources indicated the following organizations as active in fuel cells: NV Nederlandse Gasunie, GASTEC, Energy Research Center Netherlands (ECN), and the Netherlands Agency for Energy and the Environment. R\&D programs in the Netherlands include activities on PAFC, SOFC, MCFC, and PEFC. MCFC programs of ECN are the most significant.

MCFC technology was acquired by ECN in 1987 from the Institute of Gas Technology (IGT)(U.S.). ECN has focused on materials development, component fabrication, and stack technology. ECN is involved in a variety of $\mathrm{MCFC}$ projects involving such partners as IBERDOLA and TGI (Spain), British Gas(UK), and CNR-TAE (Italy). ECN has been involved in two EU JOULE II programs. The corporation Nederland BV (BCN) was established in 1991 through a joint venture of Stork, Royal Schelde, and ECN. The objective of BCN is to utilize ECN's MCFC technology. Kinetics Technology International (KTI) has demonstrated PAFC systems at the $25-\mathrm{kW}$ to $200-\mathrm{kW}$ level. A federal program on SOFC technology involves ECN, TNO, and the universities of Delft and Twente. The program concentrates on the fabrication of thin layer SOFC components. ECN is working with Seimens under an EU-funded SOFC stack-development program to optimize SOFC materials and fabrication processes. TNO works on an EU JOULE SOFC project led by British Gas. ECN has performed R\&D on PEFCs. The Center's work has concentrated on methanol reforming, hydrogen storage, cell performance, cost reduction, and system studies. ECN is leading a major EU-funded project on development of a laboratory based "brass board" PEFC system for vehicular applications. Table 4.19 indicates the levels of 1994 fuel-cell R\&D funding from public and private sources.

Table 4.19 Fuel Cell Project List for the Netherlands

\begin{tabular}{|l|l|l|l|l|}
\hline Project & $\begin{array}{l}\text { Funding } \\
\text { Source }\end{array}$ & Performer & Dates & $\begin{array}{l}\text { Funding Level } \\
\text { US\$ (million) }\end{array}$ \\
\hline Various & $\begin{array}{l}\text { Federal } \\
\text { Government }\end{array}$ & Various & 1991 -Present & 11.2 \\
\hline Various & $\begin{array}{l}\text { Private } \\
\text { Industry }\end{array}$ & Various & 1991-Present & 5.0 \\
\hline
\end{tabular}

The total advanced gas turbine R\&D program funding level in the Netherlands was US\$ 5 million in 1994. Funding levels for advanced gas turbine R\&D expenditures were supplied by the Government of the Netherlands. Advanced gas turbine R\&D has concentrated on small gas turbines ( 0.5 to $1 \mathrm{MW}$ ). The following organizations were active in advanced gas 
turbine R\&D: NV Nederlandse Gasunie, ECN, and the Netherlands Agency for Energy and the Environment. Table 4.20 indicates the funding levels for advanced gas turbine R\&D.

Table 4.20 Advanced Gas Turbine Project List for the Netherlands

\begin{tabular}{|l|l|l|l|l|}
\hline Project & $\begin{array}{l}\text { Funding } \\
\text { Source }\end{array}$ & Performer & Dates & $\begin{array}{l}\text { Funding Level } \\
\text { US\$ (million) }\end{array}$ \\
\hline Various & $\begin{array}{l}\text { Federal } \\
\text { Government }\end{array}$ & Various & 1991-Present & 3 \\
\hline Various & Private & Various & 1991-Present & 2 \\
\hline
\end{tabular}




\subsection{Norway}

R\&D funding in Norway was among the lowest of the selected countries and energy R\&D in Norway was the lowest of the selected countries. The Norwegian fuel-cell program has concentrated on development of SOFC technology. Two substantial SOFC programs are in progress or have been carried out. 1994 fuel cell expenditures were estimated at US\$ 3.9 million. Advanced gas turbine R\&D expenditures were negligible in 1994.

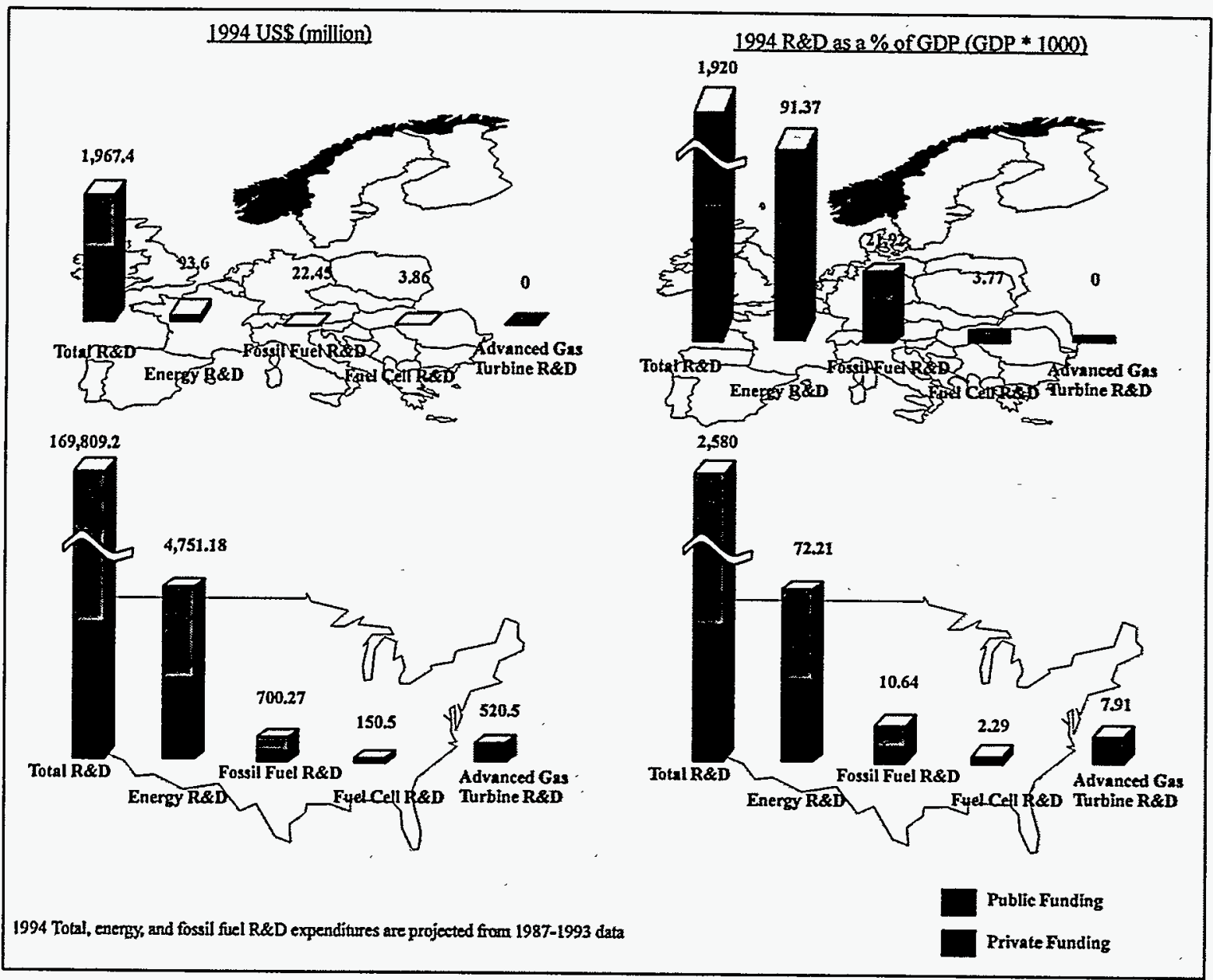

Figure 4.22. Norwegian R\&D Expenditures

\subsubsection{R\&D Expenditures}

Norway had an estimated R\&D budget of slightly less than US\$ 2 billion in 1994 (see Figure 4.22). 1994 estimates for total R\&D funding were based on the average annual percent change in R\&D funding of 4.7\% over 1987-1991. R\&D as a percentage of GDP increased 
throughout this period; however, the ratio was still lower than that of the U.S. and the average ratio of the selected countries. Approximately $60 \%$ of the total R\&D funding in Norway was provided by the federal government. Norway has the smallest energy R\&D budget of the selected countries with total expenditures estimated at US\$93.6 million. The Norwegian government increased funding for energy R\&D at an average annual rate of $3.5 \%$ during 1990-1993, however, it decreased fossil fuel R\&D funding at an average annual rate of close to $8 \%$ over the same period. Energy R\&D accounted for $4.8 \%$ of the total R\&D funded. In comparison, the U.S. contributed $2.8 \%$ of its total R\&D budget to energy R\&D. Fossil fuel R\&D expenditures in Norway were estimated at US\$22.5 million. As a percentage of GDP and total R\&D, Norwegian fossil-fuel expenditures were among the highest of the selected countries and were both greater than U.S. expenditures. Fuel cell R\&D funding in Norway was estimated at close to US\$ 4 million in 1994. As a ratio of GDP, fuel-cell R\&D expenditures in Norway were the fifth largest of the selected countries $(3.77 \%)(G D P * 1,000)$ and were greater than the U.S. ratio. Advanced gas turbine R\&D expenditures were minimal. The total estimated advanced gas turbine $R \& D$ expenditures in Norway were slightly less than US\$ 1 million.

\subsubsection{R\&D Organizational Structure}

The Research Council of Norway was established in 1993 through the merger of five research councils. Energy R\&D is coordinated by the Research Council of Norway.

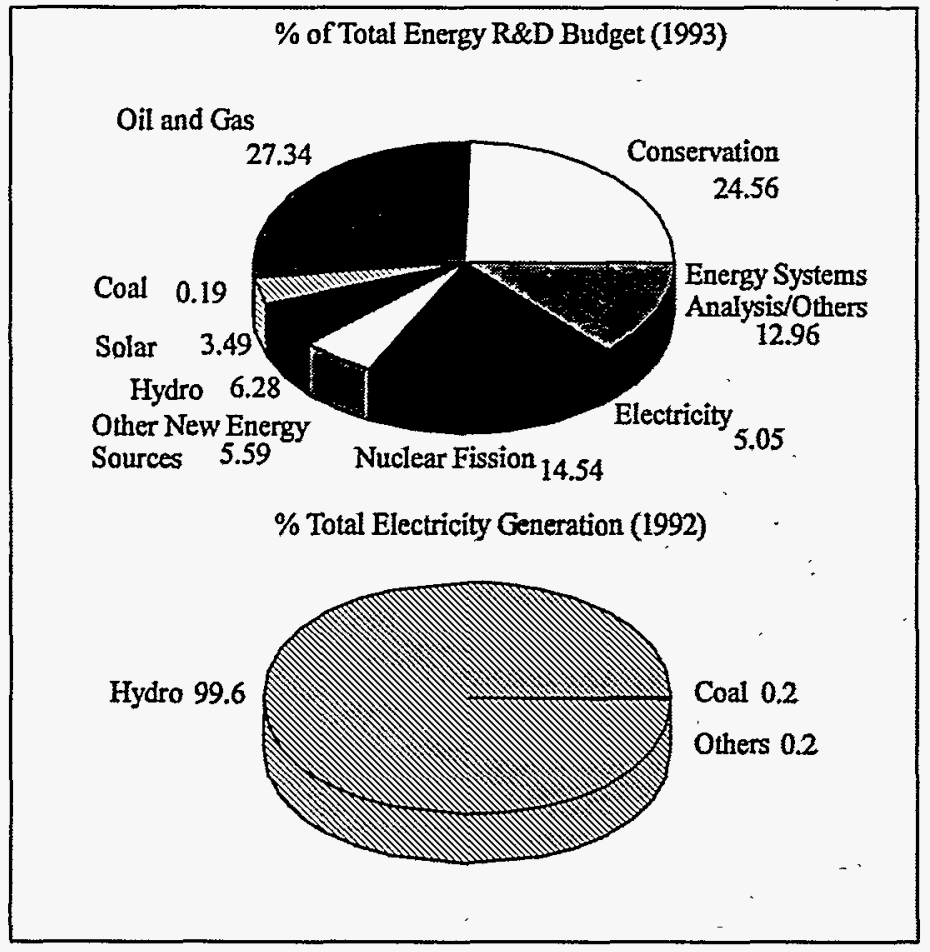

Figure 4.23. Breakdown of Norwegian Energy R\&D and Electricity Generation

\subsubsection{Energy R\&D and Sources of Electricity}

Oil and gas and conservation received more than $50 \%$ of the total energy $R \& D$ funding in Norway (see Figure 4.23). Fossil fuel R\&D was concerned primarily with oil and gas applications. A share of the oil and gas R\&D funding (US\$2.9 million) was devoted to enhanced oil and gas recovery, approximately US\$ 1 million devoted to refining transportation, and the remaining US\$ 10.2 million devoted to other oil and gas applications. Within the conservation sub-category, Norway focused on industrial energy conservation $R \& D$ programs. Of the 
US\$12.7 million devoted to conservation, 5.8 million went to industrial applications, 3.5 million to residential/commercial applications, 1.8 million to transport, and the remaining 1.7 million to other applications. Energy Systems Analysis and others received about US\$ 6.7 million and nuclear fission received approximately US\$ 7.5 million.

Norway depends on hydroelectric technology to generate electricity. Future projections indicate that Norway's dependence on hydro for generating electric power will remain greater than $99.5 \%$ through the year 2000 .

\subsubsection{Fuel Cell and Advanced Gas Turbine Projects}

1994 fuel-cell R\&D funding in Norway was estimated atl US\$3.9 million. Two primary programs received funding both of which concentrated on SOFC R\&D (see Table 4.21).

The NORCELL project concentrated on development of SOFC technology. Originally this project was centered in Norway and received funding from the Norwegian government and a consortium of three Norwegian companies (Elkem, Saga Petroleum, and Norsk Hydro). Statoil was also originally involved. Elkem, through its subsidiary, Ceramatec, in a joint venture with the McDermott Group (Babcock \& Wilcox), moved the project from Norway to the United States. As a result, the Norwegian government stopped funding in 1994, and Statoil pulled out to start its own SOFC program. The funding level of the Norwegian government for the NORCELL program totaled approximately US\$ 860,000 in 1994. Total funding provided by the Norwegian government over 1991-1994 was 50 million NOK, about (US\$ 7 million).

Statoil has been developing SOFC technology through its own private R\&D program since 1990. By mid-1995 Statoil plans to have a 10-kW SOFC plant in operation. The design and engineering phases of this project have been completed. Statoil has estimated it will spend a total of US\$ 15 million over 1990-1995.

The Norwegian utility Norsk Hydro has installed and operated a 400-kW PAFC stack supplied by Westinghouse since June 1990.

Table 4.21 Fuel Cell Project List for Norway

\begin{tabular}{|l|l|l|l|l|}
\hline Project & $\begin{array}{l}\text { Funding } \\
\text { Source }\end{array}$ & Performer & Dates & $\begin{array}{l}\text { Funding Level } \\
\text { US\$ (million) }\end{array}$ \\
\hline SOFC & Statoil & Statoil & $1990-1995$ & 15 \\
\hline $\begin{array}{l}\text { Norcell } \\
\text { (SOFC) }\end{array}$ & $\begin{array}{l}\text { Res. Council of } \\
\text { Norway }\end{array}$ & Various & 1994 & 0.86 \\
& & $1991-1994$ & 7 \\
\hline
\end{tabular}


Advanced gas turbine in 1994 was estimated as negligible (see Table 4.22). The Research Council of Norway indicated an allocation of 3 million NOK (US\$ 430,000) on advanced turbine research. However, the research was geared toward developing improved turbines in hydropower plants. No other expenditures were recorded for advanced gas turbines. As was the case in many other selected countries, Norway relied on industrial improvements in gas turbines and was concerned with installing advanced gas turbines rather than the developing them.

Table 4.22. Advanced Gas Turbines Project List for Norway

\begin{tabular}{|l|l|l|l|l|}
\hline Project & $\begin{array}{l}\text { Funding } \\
\text { Source }\end{array}$ & Performer & Dates & $\begin{array}{l}\text { Funding Level } \\
\text { US\$ (million) }\end{array}$ \\
\hline None & $\begin{array}{l}\text { Federal } \\
\text { Government }\end{array}$ & NA & NA & None \\
\hline
\end{tabular}




\subsection{Sweden}

Sweden is a country with high levels of energy and fossil fuel R\&D. The prominence of corporate giant $\mathrm{ABB}$ in the energy arena, particularly, the manufacturing of advanced gas turbines greatly influences the country's overall $R \& D$ funding levels. $A B B$ was estimated to have contributed close to US\$232 million towards gas turbine R\&D in 1994, of which US\$ 116 million was attributed to Sweden. Sweden is among the world's leaders in advanced gas turbine R\&D funding. As a percentage of GDP, advanced gas turbine funding in Sweden was the highest of any of the selected countries. Fuel-cell R\&D expenditures were estimated at US\$ 3 million. Various PAFC demonstration projects are in operation in Sweden and a number of MCFC R\&D projects are currently receiving funding.

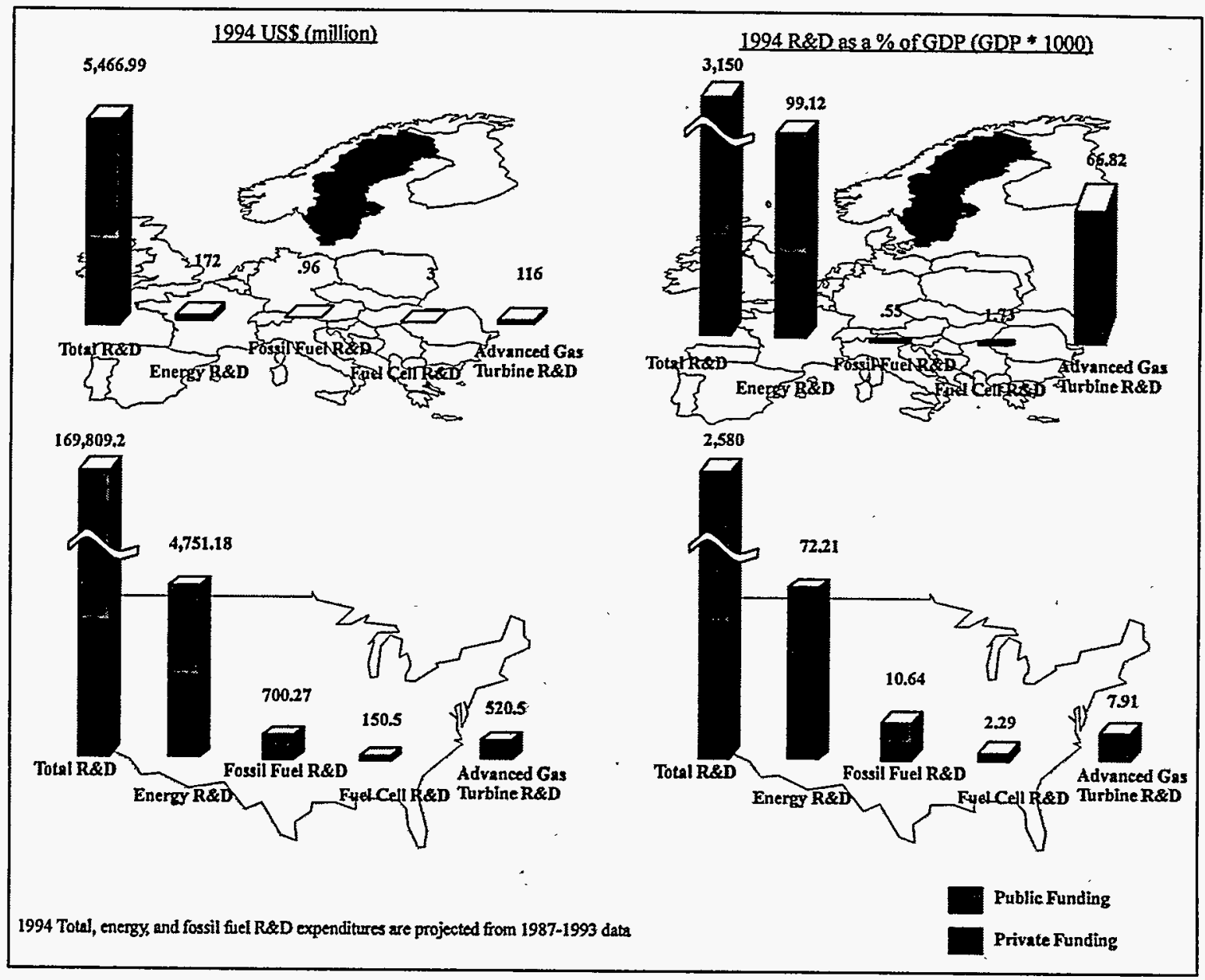

Figure 4.24. Swedish R\&D Expenditures 


\subsubsection{R\&D Expenditures}

Although the Swedish GDP decreased at annual average rate of $6.8 \%$, total R\&D expenditures have increased by an average rate of $5.3 \%$. As a percentage of GDP, R\&D was among the highest of the selected countries at 3.2\% (greater than the American level of $2.6 \%$ ). As a percentage of GDP, only Japan and Finland allocated a higher level of R\&D funding than Sweden. Funding for R\&D in Sweden is $58 \%$ financed by private industry. Energy R\&D did not receive as high a percentage of total R\&D in Sweden as in the majority of selected countries. At 3.2\% of total R\&D, Sweden was much lower than the average of $6.1 \%$. As a percentage of GDP, energy R\&D expenditures in Sweden were the sixth highest of the selected countries. Fossil fuel R\&D was estimated by K\&M at US\$ 960,000. The Swedish government cut fossil-fuel R\&D at the average annual rate of 50\% over 1990-1993. Energy and fossil fuel R\&D expenditures are likely much higher than reported in the literature due to the existence of $\mathrm{ABB}$ within Sweden. $\mathrm{ABB}$ had $\mathrm{R} \& \mathrm{D}$ expenditures of close to US\$ 2.3 billion in 1993. ABB is 50\% owned by the Swedish based company Asea and has dual headquarters in Sweden and Switzerland. Assuming that 50\% of the total R\&D funding originates in Sweden, the contribution to R\&D in Sweden by ABB alone would be US\$ 1.15 billion. Given $A B B$ 's focus on energy and fossil fuel markets a large portion of these funds is devoted to energy and fossil fuel R\&D. Therefore, the energy and fossil fuel R\&D funding levels in Sweden are likely understated in publicly available information. Fuel-cell R\&D was estimated at approximately US\$ 3 million in 1994. Advanced gas turbine R\&D in Sweden was estimated at US\$ 116 million. Due to the minuscule government budget for fossil-fuel R\&D and the enormity of ABB's R\&D budget, it was estimated that $100 \%$ of the gas turbine $R \& D$ in Sweden was funded by $A B B$.

\subsubsection{R\&D Organizational Structure}

The Ministry of Education and the Ministry of Industry and Commerce jointly oversee and coordinate publicly-supported R\&D throughout Sweden. The Ministry of Defense is also involved in the planning of public sector R\&D. The ministries provide planning and funding for various research councils, sectoral research agencies, and the National Board for Industrial and Technological Development.

The research councils promote, fund, and coordinate R\&D in specific areas. They also provide peer review and support for individual research projects. The most important councils are the Technology Research Council and the Council for Planning and Coordination of Research.

Sectoral research agencies encourage R\&D in specific societal sectors. These agencies are primarily concerned with applied research. 
The National Board for Industrial and Technological Development, part of the Ministry of Industry and Commerce, promotes applied research and dissemination of technology and information with commercial applications. The activities of the Board are focused primarily on research regarding energy supply technologies, energy efficiency, and environmental technologies.

$R \& D$ is conducted at various universities, in cooperative public/private research institutes, industry, and industrial research institutes.

Within in the private sector five academies are involved in science and engineering R\&D. These promote research within their fields of activities, facilitate national and international research contracts, and promote links between research and society. The academies select the recipients of Nobel prizes in chemistry, economics, literature, medicine, and physics. The two largest academies are the Royal Swedish Academy of Sciences and the Academy of Engineering Sciences.

\subsubsection{Energy R\&D and Sources of Electricity}

Figure 4.25 shows the breakdown of energy R\&D and sources of electricity. Sweden devoted more than $90 \%$ of its energy R\&D funding to the areas of conservation, energy systems analysis/others, other new energy sources, and nuclear technologies. The country allocated approximately $11 \%$ of its total energy R\&D budget to each of the categories of industrial, residential/commercial, and transport energy conservation. Biomass R\&D received $9.4 \%$ and nuclear fusion received $12.6 \%$ of the country's total energy R\&D budget. 


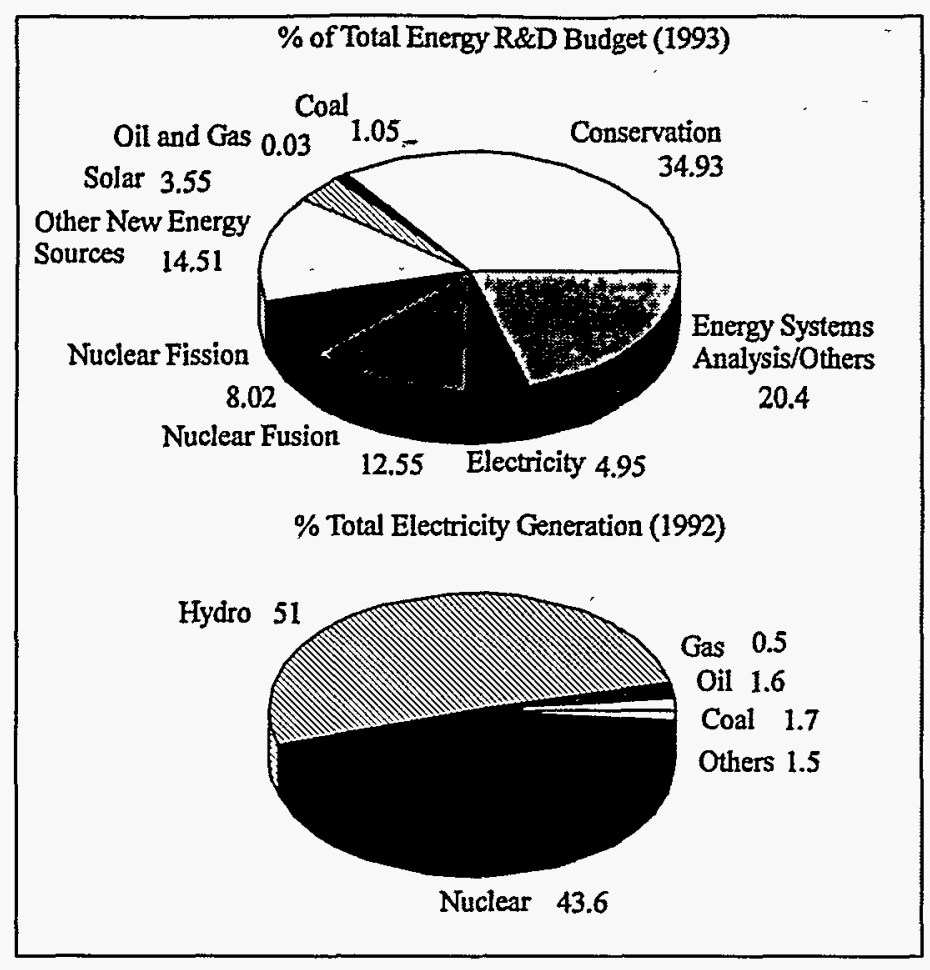

Figure 4.25. Breakdown of Swedish

Energy R\&D and Electricity Generation

Sweden relies on hydroelectricity and nuclear energy technologies to generate approximately $95 \%$ of its electricity. Fossil fuels account for $3.8 \%$ and other fuels account for $1.5 \%$. Projections have indicated that the hydroelectric share of total generated electricity will decrease to $42 \%$ by the year 2000 , and the nuclear energy share will increase to $48.5 \%$. Fossil fuels and other solid fuels (biomass) used to generate electricity are projected to increase at modest rates over the next five years.

\subsubsection{Fuel Cell and Advanced Gas Turbine Projects} 1994 fuel cell R\&D expenditures in Sweden were estimated at about US\$ 3 million (see Table 4.23). The Royal Institute of Technology is working on basic research regarding MCFC catalysts for internal reforming and new cathode materials. The project is funded by NUTEK, the Swedish National Board for Industrial and Technology Development. Sydkraft and Vattenfall, Swedish utility companies, are conducting system studies on MCFCs and are considering future demonstrations. Sydkraft has demonstrated a Fuji 50-kW PAFC stack since 1991 and a ONSI $200-\mathrm{kW}$ system since 1992 . Vattenfall has demonstrated a 50-kW Fuji system.

Table 4.23 Fuel Cell Project List for Sweden

\begin{tabular}{|l|l|l|l|l|}
\hline Project & $\begin{array}{l}\text { Funding } \\
\text { Source }\end{array}$ & Performer & Dates & $\begin{array}{l}\text { Funding Level } \\
\text { USS (million) }\end{array}$ \\
\hline MCFC & NUTEK & $\begin{array}{l}\text { Royal Institute } \\
\text { of Technology }\end{array}$ & NA & NA \\
\hline MCFC & Vattenfall & Vattenfall & NA & NA \\
\hline MCFC & Sydkraft & Sydkraft & NA & NA \\
\hline $\begin{array}{l}\text { PAFC } \\
\text { Demonstration }\end{array}$ & Vattenfall & Vattenfall & NA & NA \\
\hline
\end{tabular}


Table 4.23. Continued.

\begin{tabular}{|l|l|l|l|l|}
\hline Project & $\begin{array}{l}\text { Funding } \\
\text { Source }\end{array}$ & Performer & Dates & $\begin{array}{l}\text { Funding Level } \\
\text { US\$ (million) }\end{array}$ \\
\hline $\begin{array}{l}\text { PAFC } \\
\text { Demonstration }\end{array}$ & Sydkraft & Sydkraft & NA & NA \\
\hline
\end{tabular}

1994 expenditures for advanced gas turbine R\&D were estimated at US\$ 116 million (see Table 4.24). The Swedish government does not fund advanced gas turbine R\&D. ABB was determined to be the only substantial funder of gas turbine R\&D in Sweden. The Swedish Center of Gas Technology, whose members include the Swedish Gas Association, Sydgas $A B$, Sydkraft $A B$, Goteborg Energi $A B$, Malmo Energi $A B$, Lunds Energi $A B$, and Helsingborg Energi $A B$, concentrates on $R \& D$ involving gas distribution and end uses. The Center's total R\&D budget for 1995 is roughly US $\$ 1.5$ million. Any gas turbine R\&D supported by the Center would be negligible in comparison to ABB's.

ABB's 1993 sales were 28.3 billion US\$. ABB allocated 8.1\% of its total sales to R\&D for a total budget of US $\$ 2.3$ billion. Gas turbines manufactured by ABB fall under the power plant division, whose 1993 sales were approximately US\$ 7.9 billion and whose estimated R\&D budget was US $\$ 639$ million. Gas turbine technology development is featured by $\mathrm{ABB}$, which claims that more than $50 \%$ of its present sales in the power plant and T\&D segments were generated by products and systems developed over the past three-to-four years. New advanced gas turbines for power generation are a major reason for the young age profile of $A B B$ 's products. $A B B$ is jointly owned by $A S E A A B$ of Sweden and $B B C$ Brown Boveri Ltd. of Switzerland. ABB has R\&D centers throughout Europe (Finland, Germany, Italy, Norway, Sweden, and Switzerland); therefore, gas turbine R\&D funding could not be assigned to one specific country. As a result, all estimated gas turbine R\&D expenditures were split between Sweden and Switzerland. The total advanced gas turbine R\&D expenditures of ABB were estimated at 232 million US\$ in 1993, of which Sweden and Switzerland each contributed US\$ 116 million.

$A B B$ 's recent activities in gas turbine technology revolved around development of higher output machines with lower emissions. Increased output is attributed to higher gas firing temperatures that became viable with development of improved super alloy metals used in the turbine's blade, vanes, and other hot-gas path components, as well as improved cooling technologies. A primary goal of the $R \& D$ program was to improve gas turbine components. $\mathrm{ABB}$ developed axial/radial or axial/axial diffusers for compressor and turbine using 3-D Navier-Stokes Codes that have brought recovery coefficients to over $80 \%$ for high compactness. Radial/axial inlet housing for compressor and turbine are optimized for minimal losses, flow inhomogeneity, and aerodynamic stability. Research in that field decreased the turbine inlet housing cooling air flow and thus improved upstream combustion quality with lower NOx emission levels. Turbine rotor and blade cooling techniques have 
also been researched and improved, to the extent that compressor discharge air is utilized directly without external or supplementary coolers.

Table 4.24. Advanced Gas Turbine Project List for Sweden

\begin{tabular}{|l|l|l|l|l|}
\hline Project & $\begin{array}{l}\text { Funding } \\
\text { Source }\end{array}$ & Performer & Dates & $\begin{array}{l}\text { Funding Level } \\
\text { US\$ (million) }\end{array}$ \\
\hline None & $\begin{array}{l}\text { Federal } \\
\text { Government }\end{array}$ & Various & NA & None \\
\hline Various & ABB & ABB & 1993 & $116^{*}$ \\
& & 1992 & $69.5^{*}$ \\
\hline
\end{tabular}

* Estimated funding levels 


\subsection{Switzerland}

Switzerland's energy R\&D program was the third largest of the selected countries when compared to GDP. The Swiss allocated the greatest portion of their energy R\&D budget towards the sub-area of nuclear fission and fusion. Fossil-fuel R\&D in Switzerland is not a priority, its budget was the smallest of the energy sub-areas. Fuel-cell R\&D included projects on SOFC, PAFC, and PEFC. Two thirds of the fuel-cell R\&D projects were funded by private industry. Switzerland is among the world's leaders in advanced gas turbine R\&D. $A B B$ 's corporate headquarters is located in Switzerland and its vast advanced gas turbine R\&D budget assigned a high level of expenditures to Switzerland.

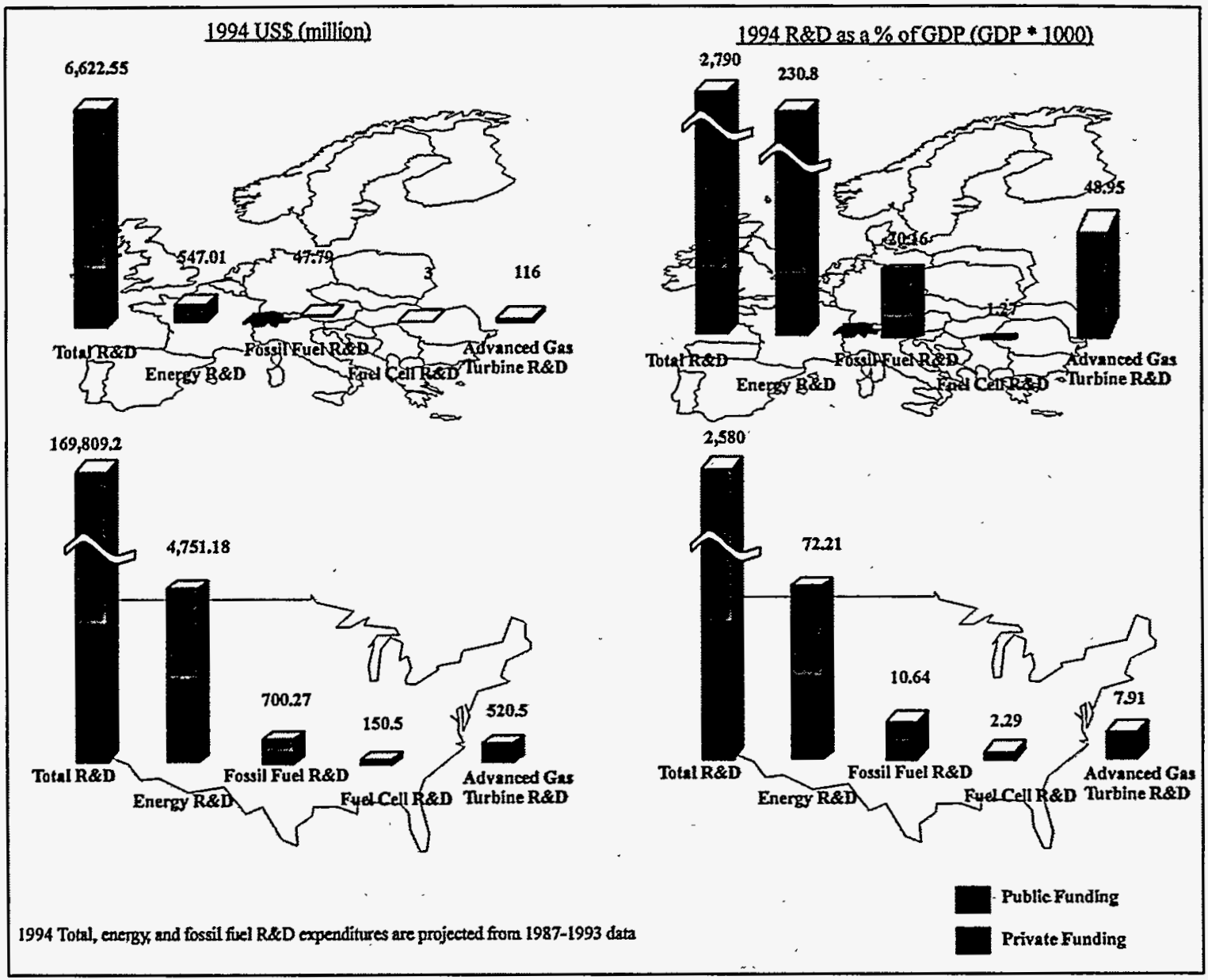

Figure 4.26. Swiss R\&D Expenditures 


\subsubsection{R\&D Expenditures}

Switzerland maintained an R\&D budget close to US\$ 6.6 billion in 1994. 1994 total R\&D expenditures were based on the average annual rate of change in $R \& D$ expenditues in Switzerland of $4.8 \%$. As a percentage of GDP, Swiss R\&D expenditures (2.8\%) were slightly greater than the average (2.4\%) of the selected countries and the U.S.A. (2.6\%). Switzerland received most of its R\&D funding from private industry (73\% of the total). Energy R\&D in Switzerland was supported with approximately US\$547 million in 1994 . As a percentage of GDP, Swiss energy R\&D expenditures were the third highest of the selected countries and were more than three times the U.S. level. Energy R\&D expenditures in Switzerland grew at an average annual rate of $4 \%$ over $1990-1993$. Fossil-fuel R\&D funding increased at an average annual rate of almost $13 \%$ over $1990-1993$. Fossil fuel R\&D expenditures in Switzerland were the eighth largest of the selected countries and were estimated at US\$ 3 million in 1994. Two thirds of the fuel cell R\&D funding was determined to come from private sources. Advanced gas turbine $R \& D$ expenditures were estimated to total US\$ 116 million in 1994. Private sources were estimated to have funded $100 \%$ of the advanced gas turbine R\&D.

\subsubsection{R\&D Organizational Structure}

The Swiss government is comprised of seven departments, each of which is responsible for submitting its own detailed research plan for parliamentary approval. The following five departments are heavily involved in R\&D activities.

- Department of the Interior. In 1990, the department financed 58\% of all federal R\&D. The following organizations fall under the deparment control: Science and Research Agency, Federal Office for Education and Science, Federal Office for Environment Protection, Federal Institutes of Technology, Governing Board of Swiss Federal Research Institutions, and Federal Research Institutes. The two Federal Institutes of Technology are the Federal Institute of Technology Zurich and the Federal Institute of Technology Lausanne. The four federal research institutes are the Paul Scherrer Institute; Federal Materials Testing Laboratory and Research Institute, Federal Institute of Forestry Research, and Federal Institute for Water Planning, Purification, and Protection.

- Department of Energy and Transportation. Oversees and coordinates federal energy R\&D. Department is advised by the Federal Commission on Energy Research.

- Department of Foreign Affairs. Oversees and coordinates Swiss involvement in international R\&D projects.

- Department of Economic Affairs. Oversees the Federal Offices of Agriculture and Industry, two offices with significant $R \& D$ budgets. 
- Department of Defense. Provides funding and coordination for defense-related R\&D.

\subsubsection{Energy R\&D and Sources of Electricity}

The Swiss allocate close to $32 \%$ of their total energy R\&D budget on nuclear fusion and fission. Solar (16.8\%), conservation (15.9\%) and electricity (14.1\%) were the only other areas to receive more than $10 \%$ of the energy R\&D budget. Fossil fuel received a small portion of the R\&D budget.

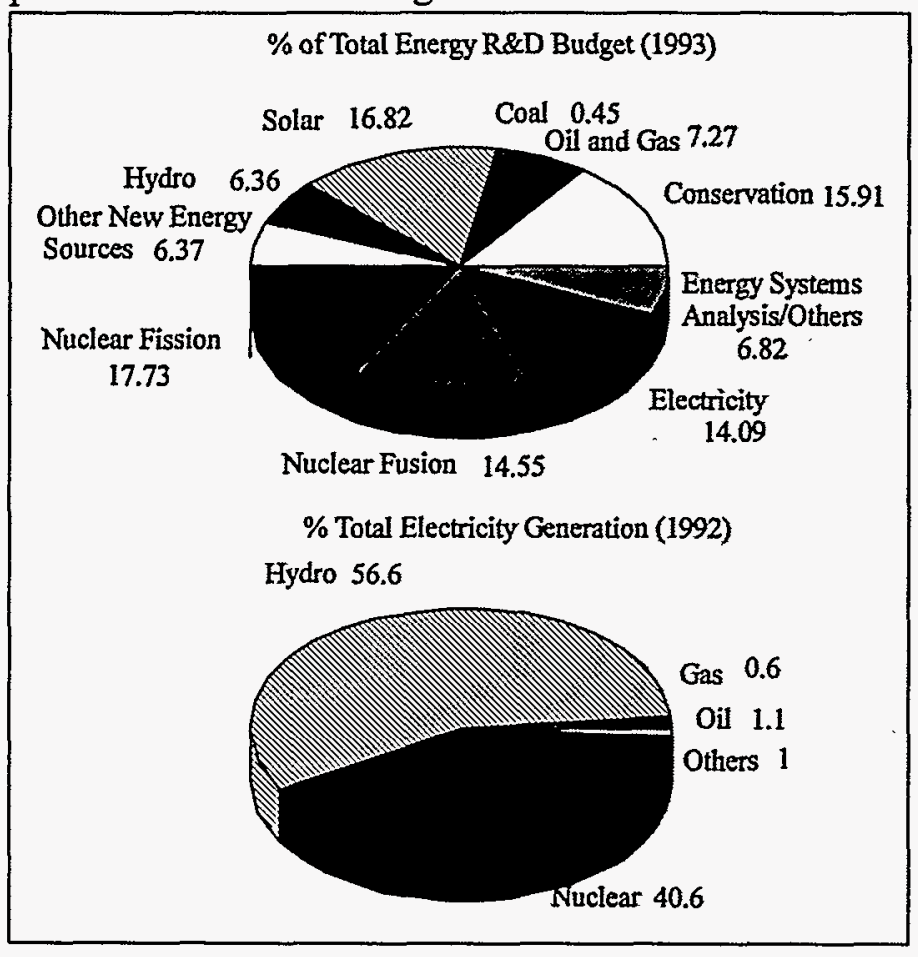

\section{Figure 4.25. Breakdown of Swiss Energy R\&D and Electricity Generation}

Hydroelectricity and nuclear energy generated $97 \%$ of Switzerland's total electricity. Future projections indicate that Switzerland will maintain its dependence on hydroelectric and nuclear sources. Fossil fuels will play a minor role (less than 5\%).

\subsubsection{Fuel Cell and Advanced Gas Turbine Projects}

The total 1994 fuel cell R\&D expenditures in Switzerland were estimated at US\$ 3 million. The most significant fuel cell R\&D in Switzerland is being partially funded and performed by Sulzer, which is developing a new SOFC stack design called HEXIS (Heat Exchanger

Integrated Stack) (see Table 4.25). The design is based on circular planar cells interlaced with heat exchanger units. A 1-kW stack is being built in cooperation with Ceramatec (U.S.). Additional SOFC programs, funded by the Swiss government, are taking place at the Universities of Lausanne and Zurich. Additional fuel-cell activities include demonstration of a ONSI 200-kW PAFC system by SIG and a PEFC project conducted by the Paul Scherrer Institute within the Swiss Department of the Interior. The PEFC project is funded by the EU and is led by Seimens (Germany). 
Table 4.25 Fuel Cell Project List for Switzerland

\begin{tabular}{|l|l|l|l|l|}
\hline Project & $\begin{array}{l}\text { Funding } \\
\text { Source }\end{array}$ & Performer & Dates & $\begin{array}{l}\text { Funding Level } \\
\text { USS (million) }\end{array}$ \\
\hline $\begin{array}{l}\text { PAFC } \\
\text { Demonstration }\end{array}$ & SIG & SIG & $1992-1997$ & NA \\
\hline $\begin{array}{l}\text { SOFC } \\
\text { (HEXIS) }\end{array}$ & $\begin{array}{l}\text { Sulzer, Swiss } \\
\text { Department of } \\
\text { Energy }\end{array}$ & Sulzer & NA & $\begin{array}{l}1(60 \% \text { from } \\
\text { government) }\end{array}$ \\
\hline SOFC & $\begin{array}{l}\text { Swiss Federal } \\
\text { Government }\end{array}$ & $\begin{array}{l}\text { Lausanne } \\
\text { University } \\
\text { Zurich } \\
\text { University }\end{array}$ & NA & NA \\
\hline PEFC & EU & $\begin{array}{l}\text { Paul Scherrer } \\
\text { Institute }\end{array}$ & NA & NA \\
\hline
\end{tabular}

The total 1994 advanced gas turbine R\&D expenditures in Switzerland were estimated at 116 million (see Table 4.26). The Swiss government did not support advanced gas turbine R\&D at appreciable levels in 1994. ABB was estimated to have provided $100 \%$ of advanced gas turbine funding.

ABB's 1993 sales were 28.3 billion US\$. ABB allocated $8.1 \%$ of its total sales to R\&D for a total budget of US $\$ 2.3$ billion. Gas turbines manufactured by ABB fall under the power plant division, whose 1993 sales were approximately US\$ 7.9 billion and whose estimated R\&D budget was US $\$ 639$ million. Gas turbine technology development is featured by $\mathrm{ABB}$, which claims that more than $50 \%$ of its present sales in the power plant and T\&D segments were generated by products and systems developed over the past three-to-four years. New advanced gas turbines for power generation are a major reason for the young age profile of ABB's products. ABB is jointly owned by ASEA AB of Sweden and BBC Brown Boveri Ltd. of Switzerland. ABB has R\&D centers throughout Europe (Finland, Germany, Italy, Norway, Sweden, and Switzerland); therefore, gas turbine R\&D funding could not be assigned to one specific country. As a result, all estimated gas turbine $R \& D$ expenditures were split between Sweden and Switzerland. The total advanced gas turbine R\&D expenditures of ABB were estimated at 232 million US\$ in 1993, of which Sweden and Switzerland each contributed US\$116 million.

ABB's recent activities in gas turbine technology revolved around development of higher output machines with lower emissions. Increased output is attributed to higher gas firing temperatures that became viable with development of improved super alloy metals used in the turbine's blade, vanes, and other hot-gas path components, as well as improved cooling technologies. A primary goal of the R\&D program was to improve gas turbine components. ABB developed axial/radial or axial/axial diffusers for compressor and turbine using 3-D Navier-Stokes Codes that have brought recovery coefficients to over $80 \%$ for high 
compactness. Radial/axial inlet housing for compressor and turbine are optimized for minimal losses, flow inhomogeneity, and aerodynamic stability. Research in that field decreased the turbine inlet housing cooling air flow and thus improved upstream combustion quality with lower No emission levels. Turbine rotor and blade cooling techniques have also been researched and improved, to the extent that compressor discharge air is utilized directly without external or supplementary coolers.

Table 4.26 Advanced Gas Turbines Project List for Switzerland

\begin{tabular}{|l|l|l|l|l|}
\hline Project & $\begin{array}{l}\text { Funding } \\
\text { Source }\end{array}$ & Performer & Dates & $\begin{array}{l}\text { Funding Level } \\
\text { US\$ (million) }\end{array}$ \\
\hline None & $\begin{array}{l}\text { Federal } \\
\text { Government }\end{array}$ & NA & NA & None \\
\hline Various & ABB & ABB & 1993 & $116^{*}$ \\
& & & 1992 & $69.5^{*}$ \\
\hline
\end{tabular}

* Estimated levels of expenditures 
The United Kingdom has the third largest R\&D budget in Europe; however, the country's energy $R \& D$ has decreased sharply since 1990 . A driving force behind the decrease was the abolishment of the Department of Energy in 1992. As a percentage of GDP, the United Kingdom had the lowest level of energy R\&D expenditures of the selected countries. It has a well-developed and extensive fuel cell program. At least 29 fuel cell projects were identified many of which are basic-level research or are partially funded by outside sources such as the EU. As a result, the total funding level for fuel cells is not as high as would be expected. Advanced gas turbine R\&D funding levels in the UK are the second highest of the selected countries. Such industry leaders as Rolls Royce and United Technologies have large R\&D budgets.

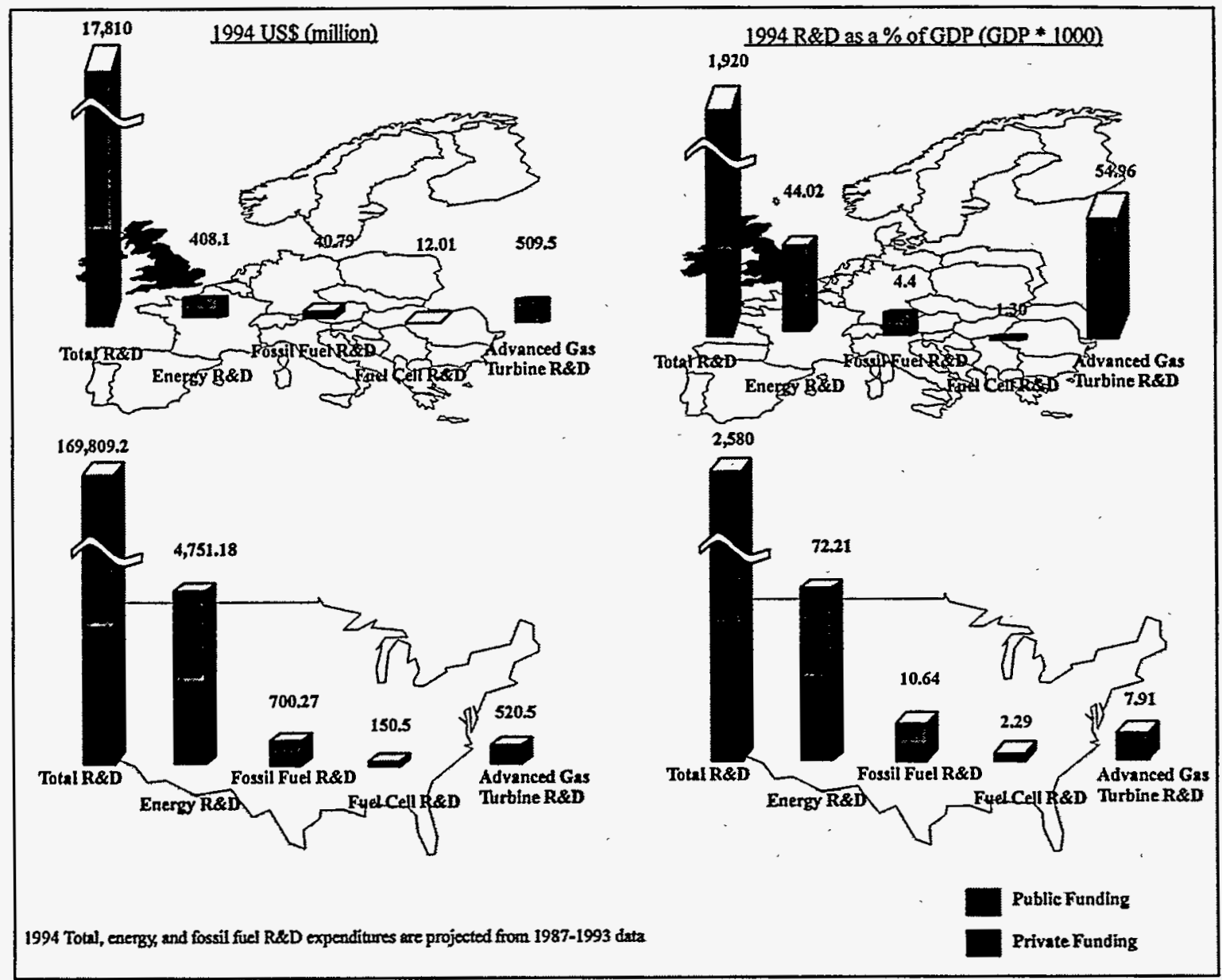

Figure 4.28. United Kingdom R\&D Expenditures 


\subsubsection{R\&D Expenditures}

The UK had the fifth largest R\&D budget of the selected countries and the third largest budget in Europe. 1994 total R\&D expenditues for the United Kingdom were estimated based on the average annual rate of change in total R\&D funding of 5\% over 1987-1991. The budget for private-funding organizations increased at a rate of $6.5 \%$, while public support increased $2.9 \%$ over the same period. The country's R\&D program is $62 \%$ privately funded. As a percentage of GDP, R\&D spending (1.9\%) was below the average of the selected countries (2.4\%) and the ratio of the United States (2.6\%) (see Figure 4.28). Energy R\&D cutbacks over 1990-1993 amounted to an average annual rate of change of $-14.3 \%$. In April 1992, the Department of Energy was abolished. Although energy R\&D spending has decreased rapidly, it is likely that energy funding levels are understated. Rolls Royce and United Technologies, for example, have a combined R\&D budget of close to US $\$ 1.4$ billion. A large percentage of these companies $R \& D$ programs can be classified as energy related. Fossil-fuel R\&D in the UK was estimated at US\$ 41 million. Fossil fuel funding has also deceased rapidly over the past several years. Although the UK is involved in numerous fuelcell R\&D projects, the estimated funding level was only US\$ 12 million. Close to $97 \%$ of the funding was determined to come from private sources. The UK is competitive with the U.S. in its estimated levels of advanced gas turbine R\&D funding. Rolls Royce, United Technologies, and European Gas Turbines all contribute substantial amounts of such funding and have full or partial ownership in the UK. Utilizing ERs the UK has the second highest level of advanced gas turbine expenditures in the world and accounts for approximately one third of total expenditures. Utilizing PPPs the UK has the highest level of advanced gas turbine expenditures in the world.

\subsubsection{R\&D Organizational Structure}

The major funders of R\&D in the UK are the Department of Defense, several civil departments, various research councils, the University Funding Council, and the Polytechnics and Colleges Funding Council. R\&D policy is determined by the various relevant government organizations. Expenditures and overall priorities for $R \& D$ are monitored by the House of Lords, the Chief Science Advisor, and the Advisory Council on Science and Technology. Following are descriptions of these departments and councils:

- Department of Energy. When abolished in April 1992, responsibilities shifted to the Department of Trade and Industry and the Department of the Environment.

- Department of Trade and Industry. Funds technology transfer and individual programs within the Third EU Framework program. Objective is to encourage innovation by industry. 
- Department of the Environment. Energy Efficiency Office of the Deparment of Energy moved here subsequent to April 1992.

- Department of Education. Funds R\&D projects in the British Academy, OECD's Center for Educational Research and Innovation, European University Institute, Royal Society, and other organizations. Objectives are to advance knowledge, produce qualified manpower at the postgraduate level, and to achieve economic, social and cultural benefits.

- Ministry of Defense. The largest funder of government R\&D. Objective of its research program is to maintain the foundation of scientific and technical expertise necessary to assist in selecting, developing, producing, and operating weapons systems, as well as to evaluate future threats and options for dealing with them.

- Research Councils. These are Medical, Agriculture and Food, Science and Engineering, Nature and Environment, and Economic and Social (Science and Engineering is to be abolished).

- Polytechnics and College Funding Council. Responsible for allocating funds made available by Parliament for education and research by polytechnics and colleges.

- University Funding Council. Responsible for administering funds made available by the Secretary of State for Education and Science to conduct university research.

- Advisory Council on Science and Technology. Advises the Prime Minister on overall national policy and priorities for R\&D.

\subsubsection{Energy R\&D and Sources of Electricity}

Nuclear fission received the greatest percentage of energy R\&D in 1993 (US\$ 80 million). Nuclear technologies, fission and fusion, received almost $60 \%$ of the country's total energy R\&D budget. Energy conservation received considerable levels of funding (13\% of the total). Energy conservation objectives were spread between industrial, residential/commercial, and transportation. Wind as a new energy source received close to $7 \%$ of the total. Fossil-fuel expenditures accounted for approximately $10 \%$. Oil and gas R\&D concentrated on activities other than enhanced oil and gas recovery, refining transportation, or oil shale and tar sands. Coal R\&D concentrated on coal production, preparation, and transportation as well as coal combustion technologies.

Coal is the UK's dominant fuel source for electric power generation. Nuclear power is also used to produce substantial amounts of electricity. Fossil-fuels produce $73.4 \%$ of electricity and Fossil-fuels and nuclear produce $97.5 \%$ of total electricity. 
Future projections have indicated that gas will be the UK's fuel of choice by the year 2010,

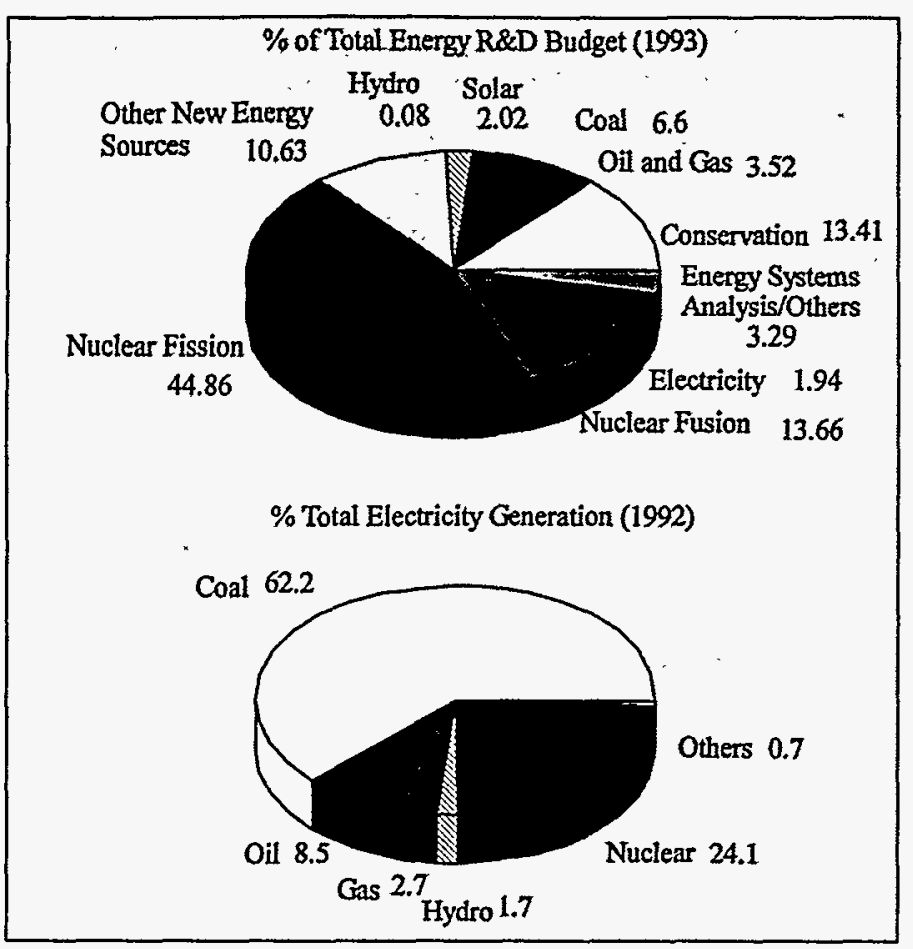

Figure 4.29 Breakdown of British

EnergyR\&D and Electricity Generation when gas is projected to account for $46 \%$ of the electricity generated. In contrast, coal and nuclear use are projected to decrease to $31.8 \%$ and $6.8 \%$ of the total electricity generated.

\subsubsection{Fuel Cell and Advanced Gas Turbine Projects}

The estimated 1994 expenditures for fuel-cell R\&D was US\$12 million. Although UK expenditures were not among the highest of the selected countries, many fuel cell R\&D projects were being financed or performed by the UK. At least 29 projects involving SOFC, MCFC, DMFC, and PEFC were identified. Many receive funding from the $\mathrm{EU}$ or are basic research projects; therefore, the actual level of expenditures in the UK is lower than expected.

Ten SOFC projects were identified in the UK. British gas is involved in at least three projects. One is a US\$ 1.4 million basic research project $50 \%$ funded by the EU JOULE II program and performed in conjunction with Tioxide Specialties, Riso Research Center (Denmark), TNO (Netherlands), and BNFL (UK). The project aims at establishing the feasibility of a novel SOFC design based on a composite cell comprising an electrolyte plate with interconnect inlays. British Gas, in cooperation with Eniricerche (Italy) is involved in a three-year program to build a balance of plant test rig. This program is funded by the Department of Trade and Industry (through ETSU) and the EU. Imperial College, a world leader in SOFC materials research and development is focusing on identifying and developing new materials to reduce the operating temperature of SOFCs. The college is participating in an EU funded project led by Seimens (Germany) and a three year project supported by the federal government aimed at the transportation applications of intermediate temperature SOFC's. The Rolls Royce Applied Science Laboratory is leading a project to evaluate a new stack design, the Integral Planar SOFC. The project is performed in conjunction with British Ceramic Research Ltd., Imperial College and the Universities of Birmingham and Keele. Keele University is also investigating alternative tubular designs as part of an EU-funded BRITE-EURAM project. GEC Alsthom and Cookson are working on a EU JOULE II program led by Siemens and Dornier, respectively. Both are working on the development of sealing and bonding materials. EA Technology is evaluating microwave assisted firing as a potential process for improving SOFC stack manufacture (see Table 4.27). 
British Gas has been investigating MCFC technology since 1987. The program currently focuses on system studies, catalyst development and evaluation, and internal-reforming testing. The program has strong ties to the MCFC program of $E C N / B C N$ of the Netherlands.

The UK supports PEFC R\&D through the Department of Trade and Industry. At least 15 R\&D projects were identified. Major activities for PEFC R\&D focus on the fuel-processing system and the membrane electrode. Johnson Matthey is involved in at least five PEFC projects, which include electrode development, catalyst and manufacturing process development with Ballard (Canada), IEA PEFC Annex IV involvement, reforming of methanol, and development of palladium membrane technology. British Gas is involved in three different projects on steam reformation and "clean-up" methanation. CJB Developments, in collaboration with VSEL and Ballard (Canada), has been involved in the development of methanol reformers and $\mathrm{CO}$ selective oxidation systems for PEFC for the past six years. The aim of this collaboration is to demonstrate an integrated PEFC system at $10-\mathrm{kW}$ scale, incorporating a methanol fuel processor, Ballard $5-\mathrm{kW}$ stacks, and a power conditioning unit. VSEL has been involved in a collaborative project between CJB Development, Lucas Advanced Engineering, and Rover Cars to study hybrid vehicles. Rolls Royce and Associates are developing the autothermal reformer concept. Loughborough University has developed a small PEFC stack for transport applications. In addition, Loughborough University has been involved in a large study investigating methods of improving MEA performance that is run by Siemens (Germany).

Table 4.27. Fuel Cell Project List for the United Kingdom

\begin{tabular}{|l|l|l|l|l|}
\hline Project & $\begin{array}{l}\text { Funding } \\
\text { Source }\end{array}$ & Performer & Dates & $\begin{array}{l}\text { Funding Level } \\
\text { USS (million) }\end{array}$ \\
\hline $\begin{array}{l}\text { SOFC plate } \\
\text { cells }\end{array}$ & $\begin{array}{l}\text { British Gas, } \\
\text { EU-JOULE II } \\
(50 \%), \\
\text { Government } \\
(5 \%)\end{array}$ & $\begin{array}{l}\text { Brit. Gas, } \\
\text { Tioxide, BNFL }\end{array}$ & $1993-1994$ & 1.4 \\
\hline IP-SOFC & $\begin{array}{l}\text { Rolls Royce } \\
\text { Government } \\
60 \%)\end{array}$ & $\begin{array}{l}\text { Rolls Royce, } \\
\text { Birmingham } \\
\text { University, } \\
\text { Keele } \\
\text { University, } \\
\text { CERAM } \\
\text { Research }\end{array}$ & $1993-1994$ & 0.5 \\
\hline
\end{tabular}


Table 4.27 Continued.

\begin{tabular}{|c|c|c|c|c|}
\hline Project & $\begin{array}{l}\text { Funding } \\
\text { Source }\end{array}$ & Performer & Dates & $\begin{array}{l}\text { Funding Level } \\
\text { USS (million) }\end{array}$ \\
\hline $\begin{array}{l}\text { SOFC stack } \\
\text { development }\end{array}$ & $\begin{array}{l}\text { EU (50\%), } \\
\text { CPSL, Sapco, } \\
\text { Viking }\end{array}$ & $\begin{array}{l}\text { Keele } \\
\text { University, } \\
\text { Sapco, Viking, } \\
\text { CPSL }\end{array}$ & 1994-1997 & 2.0 \\
\hline SOFC & $\overline{N A}$ & \begin{tabular}{|l} 
Keele \\
University
\end{tabular} & $\overline{N A}$ & $\widehat{N A}$ \\
\hline $\begin{array}{l}\text { SOFC low } \\
\text { temperature }\end{array}$ & EU, Seimens & $\begin{array}{l}\text { Imperial } \\
\text { College }\end{array}$ & $\overline{\mathrm{NA}}$ & $\widehat{\mathrm{NA}}$ \\
\hline $\begin{array}{l}\text { SOFC low } \\
\text { temperature }\end{array}$ & Government & $\begin{array}{l}\text { Imperial } \\
\text { College }\end{array}$ & $1993-1996$ & \begin{tabular}{|l|}
0.7 \\
\end{tabular} \\
\hline $\begin{array}{l}\text { SOFC balance } \\
\text { of plant }\end{array}$ & $\begin{array}{l}\text { British Gas, } \\
\text { Government } \\
(25 \%) \\
\text { EU }(50 \%)\end{array}$ & $\begin{array}{l}\text { British Gas, } \\
\text { Eniricerche }\end{array}$ & \begin{tabular}{|c|}
$1994-1996$ \\
\end{tabular} & 1.5 \\
\hline $\begin{array}{l}\text { SOFC sealing } \\
\text { and bonding }\end{array}$ & $\overline{E U}$ & $\begin{array}{l}\text { GEC Alsthom, } \\
\text { Cookson }\end{array}$ & $\overline{\mathrm{NA}}$ & $\overline{\mathrm{NA}}$ \\
\hline $\begin{array}{l}\text { SOFC internal } \\
\text { reforming }\end{array}$ & British Gas & British Gas & NA & NA \\
\hline $\begin{array}{l}\text { SOFC } \\
\text { microwave- } \\
\text { assiṣted firing }\end{array}$ & $\begin{array}{l}\text { EA } \\
\text { Technology }\end{array}$ & $\begin{array}{l}\text { EA } \\
\text { Technology }\end{array}$ & NA & $\mathrm{NA}$ \\
\hline MCFC stack & $\begin{array}{l}\text { British Gas, } \\
\text { EU (50\%) }\end{array}$ & $\begin{array}{l}\text { British Gas, } \\
\text { ECN } \\
\text { (Netherlands), } \\
\text { CNR-TAE } \\
\text { (Italy) }\end{array}$ & 1993-1995 & 3.0 \\
\hline $\begin{array}{l}\text { PEFC system } \\
\text { demonstration }\end{array}$ & \begin{tabular}{|l} 
VSEL, \\
CJB \\
Developments
\end{tabular} & \begin{tabular}{|l|} 
VSEL, \\
CJB \\
Developments
\end{tabular} & \begin{tabular}{|l|} 
prior to 1990 \\
\end{tabular} & 1.0 \\
\hline
\end{tabular}


Table 4.27 Continued.

\begin{tabular}{|c|c|c|c|c|}
\hline Project & \begin{tabular}{|l} 
Funding \\
Source
\end{tabular} & Performer & Dates & $\begin{array}{l}\text { Funding Level } \\
\text { US\$ (million) }\end{array}$ \\
\hline PEFC reformer & $\begin{array}{l}\text { CJB, ECN } \\
\text { (Netherlands) }\end{array}$ & CJB, ECN & $1994-1996$ & 0.25 \\
\hline $\begin{array}{l}\text { PEFC vehicle } \\
\text { demonstration }\end{array}$ & $\begin{array}{l}\text { VSEL, CJB, } \\
\text { Rover, and } \\
\text { Lucas } \\
\end{array}$ & $\begin{array}{l}\text { VSEL, CJB, } \\
\text { Rover, and } \\
\text { Lucas } \\
\end{array}$ & $1993-1997$ & $\mathrm{NA}$ \\
\hline $\begin{array}{l}\text { PEFC } \\
\text { development }\end{array}$ & $\begin{array}{l}\text { Johnson } \\
\text { Matthey, } \\
\text { Government } \\
(30 \%)\end{array}$ & $\begin{array}{l}\text { Johnson } \\
\text { Matthey }\end{array}$ & $1993-1994$ & 0.75 \\
\hline$\overline{\mathrm{PEFC}}$ & \begin{tabular}{|l|} 
Johnson \\
Matthey
\end{tabular} & $\begin{array}{l}\text { Johnson } \\
\text { Matthey }\end{array}$ & $\overline{\mathrm{NA}}$ & $\overline{N A}$ \\
\hline PEFC (Ballard) & $\begin{array}{l}\text { Johnson } \\
\text { Matthey }\end{array}$ & $\begin{array}{l}\text { Johnson } \\
\text { Matthey }\end{array}$ & $\overline{\mathrm{NA}}$ & NA \\
\hline PEFC (IEA) & $\begin{array}{l}\text { Johnson } \\
\text { Matthey }\end{array}$ & $\begin{array}{l}\text { Johnson } \\
\text { Matthey }\end{array}$ & NA & $\overline{N A}$ \\
\hline $\begin{array}{l}\text { PEFC (Hot } \\
\text { Spot) }\end{array}$ & $\begin{array}{l}\text { Johnson } \\
\text { Matthey }\end{array}$ & $\begin{array}{l}\text { Johnson } \\
\text { Matthey }\end{array}$ & $\overline{N A}$ & $\overline{\mathrm{NA}}$ \\
\hline PEFC clean up & $\begin{array}{l}\text { British Gas, } \\
\text { Government } \\
(50 \%)\end{array}$ & British Gas & $1992-1994$ & 0.3 \\
\hline $\begin{array}{l}\text { PEFC ceramic } \\
\text { membrane }\end{array}$ & British Gas & British Gas & $\overline{\mathrm{NA}}$ & $\overline{N A}$ \\
\hline $\begin{array}{l}\mathrm{PEFC} \text { natural } \\
\text { gas reformer }\end{array}$ & $\begin{array}{l}\text { British Gas, } \\
\text { Government } \\
(50 \%)\end{array}$ & British Gas & $1992-1994$ & 0.4 \\
\hline $\begin{array}{l}\text { PEFC } \\
\text { autothermal } \\
\text { reformer }\end{array}$ & $\begin{array}{l}\text { Rolls Royce, } \\
\text { Government } \\
(30 \%)\end{array}$ & Rolls Royce & $1992-1994$ & 0.4 \\
\hline
\end{tabular}


Table 4.27. Continued.

\begin{tabular}{|l|l|l|l|l|}
\hline Project & $\begin{array}{l}\text { Funding } \\
\text { Source }\end{array}$ & Performer & Dates & $\begin{array}{l}\text { Funding Level } \\
\text { US\$ (million) }\end{array}$ \\
\hline $\begin{array}{l}\text { PEFC EU } \\
\text { BRITE } \\
\text { EURAM }\end{array}$ & $\begin{array}{l}\text { AEA } \\
\text { Technology, } \\
\text { EA } \\
\text { Technology, } \\
\text { PowerGen, } \\
\text { Government } \\
(50 \%), \\
\text { EU }\end{array}$ & $\begin{array}{l}\text { AEA } \\
\text { Technology, } \\
\text { EA } \\
\text { Technology, } \\
\text { PowerGen }\end{array}$ & 1994 & 3.0 \\
\hline $\begin{array}{l}\text { PEFC } \\
\text { (Siemens) }\end{array}$ & Seimens & $\begin{array}{l}\text { Loughborough } \\
\text { University }\end{array}$ & NA & \\
\hline $\begin{array}{l}\text { PEFC stack } \\
\text { development }\end{array}$ & Government & $\begin{array}{l}\text { Loughborough } \\
\text { University }\end{array}$ & $1992-1994$ & 0.3 \\
\hline
\end{tabular}

1994 advanced gas turbine R\&D expenditures were estimated at US $\$ 509.5$ million. Rolls Royce, United Technologies, and GEC Alsthom (European Gas Turbines) provided the bulk of such funding. The federal government did not allocate any of its R\&D budget to advanced gas turbines.

Rolls Royce had 1993 sales of slightly higher than US\$ 5 billion. The compnay's product line includes aero, industrial and marine gas turbines, power generation, nuclear engineering and materials handling. Rolls Royce had R\&D expenditures of US\$ 386 million in 1993. Its $R \& D$ program concentrates mostly on the improving its aerospace and industrial powerproduct lines. A large portion of these two programs focus on the development of gas turbines or on technology that is transferable to gas turbine development. As a result, it was calculated that Rolls Royce allocated close to US $\$ 330$ million of advanced gas turbine R\&D.

Rolls Royce produces the Industrial Trent gas turbine and the Industrial RB211 gas turbine for power generation applications. The R\&D program focused on the development of a dry low-emissions combustion system, power increases, and efficiency gains. The industrial RB211 adopted technology developed for the aero RB211-524G engine that increased the power output 10\%. In December 1991, a US\$160 million contract was awarded to Westinghouse Marine Division of Sunnyvale (U.S.). Rolls-Royce is teamed with Westinghouse to undertake the advanced development of the gas turbine.

United Technologies (1993 sales of US $\$ 20.7$ million) is comprised of five different divisions; Pratt and Whitney, Flight Systems, Carrier, Otis, and Automotive. Gas turbines are manufactured under the Pratt and Whitney (1993 sales of US\$ 5.9 billion) which 
produces commercial and military jet engines, small gas-turbine engines, rocket engines, space propulsion systems, and modified aircraft engines for electric power generation. R\&D expenditures for United Technologies totaled US\$ 1.137 billion in 1993. The estimated R\&D budget of Pratt and Whitney was US $\$ 324$ million. It was determined that approximately $50 \%$ of the total R\&D of Pratt and Whitney involved gas turbines or gas turbine technology. Therefore, the estimated expenditures of United Technologies on advanced gas turbine R\&D was US\$162 million.

Pratt and Whitney's R\&D program focuses on improving military fighter and transport engines and space propulsion systems. Knowledge gained from these programs is applicable to advanced gas turbines for electric power generation. For example, the compressor technology program performed non-linear blade kinematic analysis and rig testing throughout the development of a lightweight, high LCF life, high pressure ratio, flankmilled fan for a production engine. In addition, combustor research focused on emissions reduction, stability enhancement, noise reduction, and analytical (CFD) modeling. Further R\&D included turbine cooling research focused on reducing cooling flow requirements and improving turbine durability at higher operating temperatures, as well as materials research aimed at improving durability and performance while meeting the needs of turbines operating at higher temperatures.

European Gas Turbines (EGT) is involved in the manufacture, research, and development of advanced gas turbines (see Table 4.28). EGT sells the TYPHOON, TORNADO, HURRICANE, and various other gas turbines. EGT has established a Joint Technology Council with General Electric to promote technological collaboration on a broad front. The Joint Technology Office has conducted research on a wide range of design studies for both industrial and marine applications and aero engine projects. In addition, it has released a dry low $\mathrm{NO}_{\mathrm{X}}$ system for its Frame 3 and 5 gas turbines. EGT is $90 \%$ owned by GEC Alsthom and $10 \%$ owned by General Electric. GEC Alsthom is ownced $50 \%$ by GEC of the UK and $50 \%$ by Alcatel Alsthom of France. Therefore, European Gas Turbines is $45 \%$ owned by GEC; it was assumed that $45 \%$ of the advanced gas turbine R\&D expenditures were attributable to UK sources. European Gas Turbines (EGT) has had R\&D expenditures of approximately 50 million ECU (US\$ 40 million) over each of the past three years (19931991). One-hundred percent of EGT R\&D was estimated to be directed to advanced gas turbine R\&D.

Table 4.28. Advanced Gas Turbines Project List for the United Kingdom

\begin{tabular}{|l|l|l|l|l|}
\hline Project & $\begin{array}{l}\text { Funding } \\
\text { Source }\end{array}$ & Performer & Dates & $\begin{array}{l}\text { Funding Level } \\
\text { US\$ (million) }\end{array}$ \\
\hline Various & Government & NA & NA & None \\
\hline
\end{tabular}


Table 4.28. Continued.

\begin{tabular}{|l|l|l|l|l|}
\hline Project & $\begin{array}{l}\text { Funding } \\
\text { Source }\end{array}$ & Performer & Dates & $\begin{array}{l}\text { Funding Level } \\
\text { USS (million) }\end{array}$ \\
\hline Various & Rolls Royce & Rolls Royce & 1993 & $328^{*}$ \\
\hline Various & $\begin{array}{l}\text { GEC Alsthom } \\
\text { EGT }\end{array}$ & EGT & 1992 & $297^{*}$ \\
\hline Various & $\begin{array}{l}\text { United } \\
\text { Technologies } \\
\text { (Pratt and } \\
\text { Whitney) }\end{array}$ & Pratt Whitney & 1993 & $17.5^{*}$ \\
\hline
\end{tabular}

* Estimated levels of expenditures 


\subsection{United States}

The U.S. is the world's leader in R\&D expenditures, however, energy R\&D expenditures are much lower than levels of Japan. The U.S. has significantly reduced the funding level of the energy $R \& D$ program since 1990 . As a result, the country's energy $R \& D$ as percentage of GDP is among the lowest of the selected countries. In addition, fossil fuel R\&D funding received tremendous cuts over the past several years; as a percentage of GDP, is only the ninth highest of the selected countries. Fuel-cell R\&D expenditures in the U.S.A. are strong but less than the level allocated by the Japanese. Advanced gas turbine R\&D expenditures in the U.S. were estimated as the highest in the world.

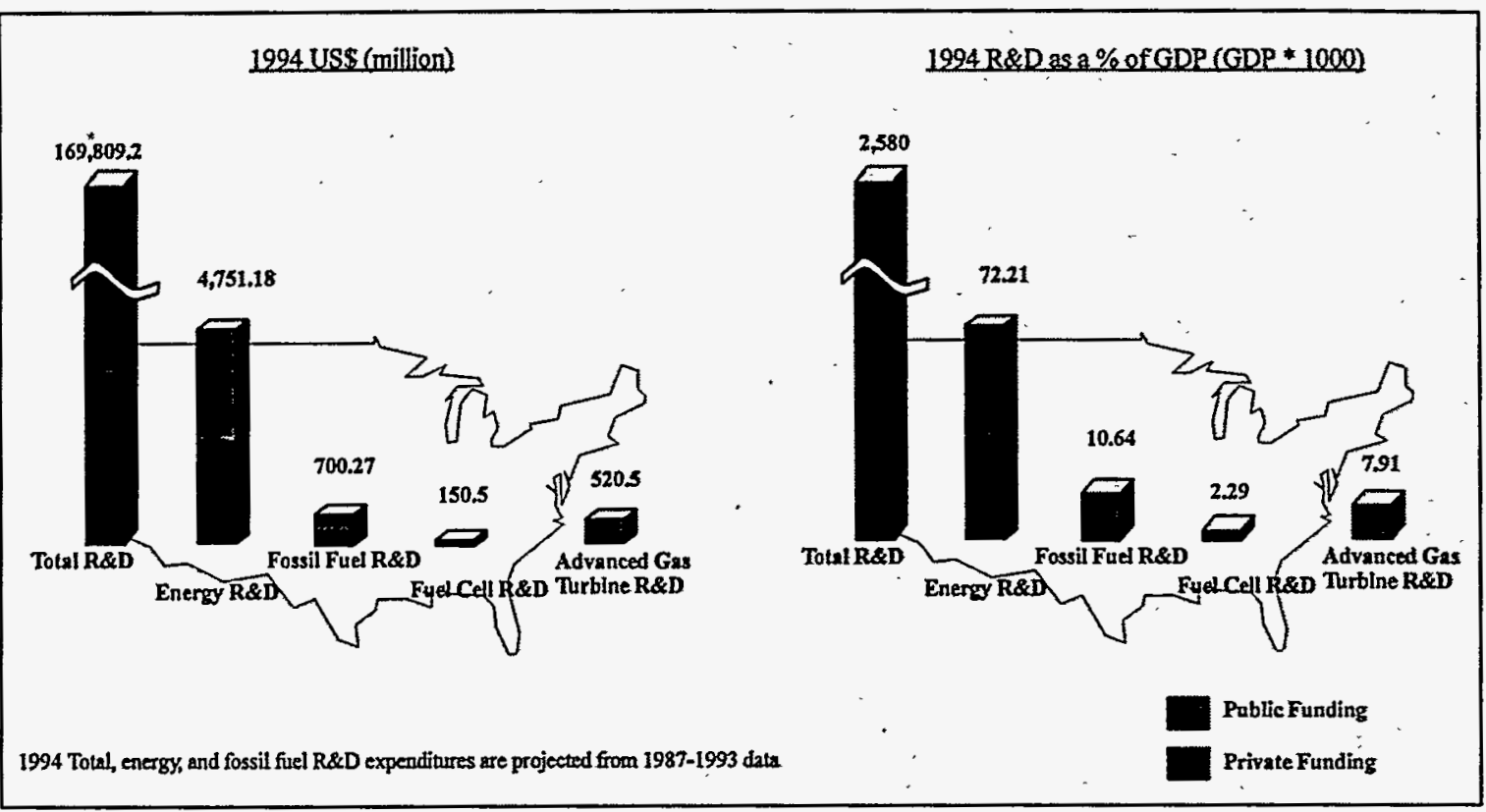

Figure 4.30 American R\&D Expenditures

\subsubsection{R\&D Expenditures}

The U.S. is the world's leader in R\&D expenditures, which accounted for $33 \%$ of the total R\&D funding of the selected countries. As a percentage of GDP, the U.S. (see Figure 4.30) allocated slightly higher than the average of the selected countries. Its R\&D budget increased at a below average rate of $4.1 \%$ over 1988-1992. Public expenditures increased $3.3 \%$ and private expenditures increased $4.8 \%$. U.S. energy R\&D is funded at the second highest level of the selected countries; however, as a percentage of total R\&D, American energy R\&D expenditures are minimal in relation to other selected countries. Energy R\&D accounted for $2.8 \%$ of the total U.S. R\&D compared to the $6 \%$ average value of the selected countries. Germany and the U.K. (which abolished its Department of Energy in 1992), were 
the only countries to allocate lower percentages of their total R\&D to energy $R \& D$. The U.S.'s average annual rate of change for energy spending was $-4.3 \%$ over 1990-1993. Fossilfuel R\&D expenditures were cut over the past two years. The average annual rate of change in fossil fuel R\&D expenditures was $-22.7 \%$. Fossil fuel expenditures make up $18.2 \%$ of the U.S. energy R\&D budget. As a result, the U.S. allocated the second highest level of funding, in terms of total US\$, to fossil-fuel expenditures of the selected countries. As a percentage of GDP, the U.S. had the ninth highest level of fossil fuel R\&D expenditures of the selected countries. Fuel-cell expenditures in the U.S. were the second highest in the world, estimated at a total of US\$ 150 million. Advanced gas turbine expenditures in the U.S. were the highest in the world, estimated at US\$ 521 million.

\subsubsection{R\&D Organizational Structure}

Funding for U.S. R\&D comes from one of four sources; government, industry, universities, and non-profit organizations. The overwhelming majority of funding is through government and industry.

The federal government is composed of 14 departments and several mission agencies. Each has its own research priorities and budgets. Annually the President of the U.S. requests funding from Congress for each of the departments and agencies. Prior to that request, the President consults with such advisors and councils as, the National Security Council; Council of Economic Advisors; Office of Management and Budget; Office of Science and Technology Policy; Federal Coordinating Council for Science, Engineering and Technology; and President's Council of Advisors on Science and Technology. The primary organizations that fund R\&D in the U.S. federal government are the Department of Defense, Department of Energy, National Science Foundation, National Institutes of Health, and National Aeronautics and Space Administration.

- Department of Defense. Funds approximately $60 \%$ of the total R\&D of the federal government. R\&D policy focuses on the detailed research, testing, and evaluation of new weapon systems as well as the development of advanced technologies. Fuel-cell R\&D is funded by the Department of Defense.

- Department of Energy: Primary U.S. funder of energy R\&D. Plays a significant role in the support of the nation's basic science community.

- National Science Foundation: Primary funder of basic science at the level of the individual researcher or small research group. Research projects are selected by peer review. Funding has increased over the past several years due to a belief in the current administration that basic research is fundamental to the nation's long-term economic growth. 
- National Institutes of Health. Primary funder of basic and applied research in the biomedical field. Lead agency for the Human Genome Project.

- National Aeronautics and Space Administration. Primary civilian agency concerned with the ability to use the environment of space.

\subsubsection{Energy R\&D and Sources of Electricity}

Figure 4.31 indicates the breakdown of the energy R\&D budget and the sources of electricity generation. The U.S. allocated $18.2 \%$ of its total R\&D budget to fossil fuel R\&D in 1993 . Compared to the rest of the selected countries, the fossil-fuel expenditures, as a percentage

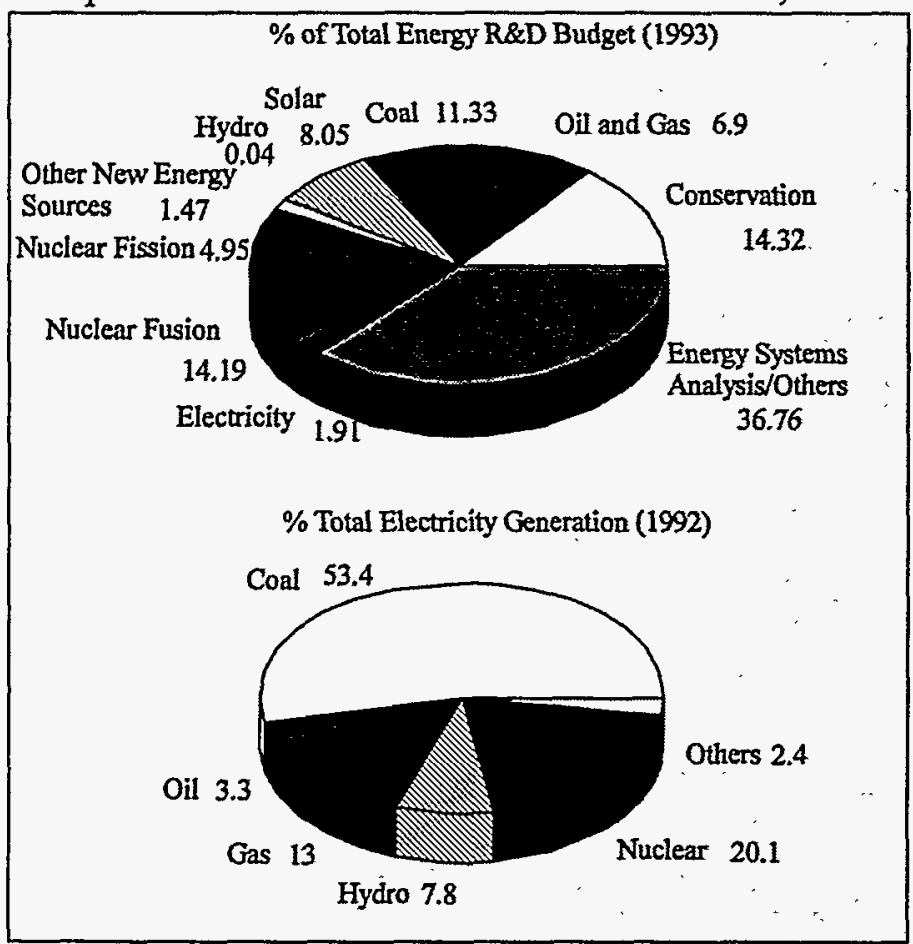

\section{Figure 4.31 American Energy R\&D and Electricity Generation Breakdown}

of energy $R \& D$, were the eighth highest of the selected countries. The average percentage of total energy budget allocated to fossil fuel for the selected countries was $11.5 \%$ in 1993. Nuclear technologies received much lower percentages of total energy $R \& D$ funding than in the other selected countries. The U.S. allocated approximately $19 \%$ of its total energy R\&D budget to nuclear fusion and fission. In comparison, Japan devoted $85 \%$ of its energy $R \& D$ budget to nuclear areas. The average level of expenditures on nuclear $R \& D$ for the selected countries was approximately $61 \%$. The U.S. allocated 190 million to Solar in 1993. At that level, the U.S. supported solar at levels higher than nuclear fission or oil and gas. At $8 \%$ of the total energy R\&D the U.S. solar R\&D program was much

greater than the $4.3 \%$ average for the selected countries.

Coal is the predominant fuel used for electricity generation in the U.S.. Fossil fuels were used to generate approximately $70 \%$ of electricity in 1992 . Nuclear and hydro are the only other electricity generation technologies with significant U.S. shares. Future projections indicate the U.S. will continue its heavy use of coal for electricity generation. Nuclear power will slowly be replaced by an expanding gas-based electricity generation market, while oil and hydroelectric shares will remain relatively flat. 


\subsubsection{Fuel Cell and Advanced Gas Turbine Projects}

Fuel cell R\&D funding in the U.S. was estimated at US\$ 150.5 million in 1994. The predominant funders are the Department of Energy, Department of Defense, Gas Research Institute, Electric Power Research Institute, gas and electric utilities, National Aeronautics and Space Administration and various private corporations, including MC Power, Westinghouse, Energy Research Corporation, Allied Signal, and International Fuel Cells/ONSI.

The Department of Energy allocated US\$ 51.8 million for fuel cell funding in 1994 and US\$ 51.1 million in 1993 (see Table 4.29). Funding is provided for R\&D projects on MCFC, SOFC, and PEFC. Focal elements of the overall fuel cell plan include:

- Development and demonstration of MCFC and SOFC technologies for electric utility, commercial, and industrial applications

- Cost reduction and durability improvements to enable production of competitive-market entry power plants

- Evaluation of advanced fuel-cell concepts and configurations for electric utility, industrial, residential, and commercial sector applications

- Support of advanced research needed to develop fuel-cell technologies.

- Cooperation with commercialization activities

- Coordination with fuel-cell development and testing activities of the Department of Defense, Department of Energy's Office of Energy Efficiency and Renewable Energy, Electric Power Research Institute, Gas Research Institute, National Aeronautics and Space Administration, electric and gas utilities, and manufacturing companies.

The fuel-cell program strategy is to assist the private sector in developing MCFC and SOFC technologies and to participate in field tests that improve projects for commercialization by the private sector. Commercialization plans have been formulated by the private sector for market entry of these power plants fueled by natural gas in the late 1990's. Introduction of larger power plants with integrated coal gasifiers is anticipated prior to 2010 .

The Department of Defense allocated US\$ 35.4 million for fuel-cell activities in 1994. In 1993, it initiated a program to demonstrate and use commercially-produced fuel-cell power plants at sites located on military bases. In addition, it began a program to develop fuel-cell power plants for defense applications. The focus of this program is on the need for durability and operation on logistic diesel and jet fuels. 
The Gas Research Institute (GRI) fuel cell program focuses on on-site cogeneration and electric utility dispersed power generation equipment fueled with natural gas. In the past, GRI has focused on PAFC technology. Since 1992 GRI's program focus has shifted to MCFC and SOFC technologies. The objectives of GRI's fuel-cell program are to develop and deploy fuel-cell technology for cogeneration and power generation systems based on advanced MCFC concepts and to identify new, economical concepts for planar SOFC electrolytes and thin film structures. GRI's budget for fuel-cell activities in 1994 was US\$ 3.5 million and its planned budgets are US\$ 3.85 million and US\$ 4.5 million for 1995 and 1996 , respectively. Cooperative support for research will provide US\$ 12.1 million and US\$ 16.1 million in 1995 and 1996, respectively.

The Electric Power Research Institute's 1994 fuel-cell R\&D budget is US\$ 6 million in direct funding, plus an additional US\$ 6 million in cofunding from member utilities. The objective of its program is to develop and commercialize electric power plants with the highest possible efficiency and least environmental intrusion. Major program objectives over the next five years are to:

- Complete technical and economic evaluation of the 1- and 11-MW PAFC power plants being demonstrated overseas

- Initiate utility demonstrations of $250-\mathrm{kW}$ and 2-MW MCFC power plants in dispersed generation applications

- Stimulate fuel-cell commercialization programs with member utilities

- Define approaches and risks to the development of yet more efficient (49 to $57 \%)(7,000$ $-6,000 \mathrm{BTU} / \mathrm{kW}$ ) fuel-cell power plants

- Demonstrate MCFC on coal-derived medium BTU synthesis gas

- Develop MCFC and SOFC technology applicable for central station utility power plants in the late 1990s

The National Aeronautics and Space Administration (NASA) has been involved in fuel-cell development since 1960 and has funded alkaline fuel-cell development for use on the space shuttle. The current NASA program is directed towards low temperature hydrogen-oxygen cells for regenerative and primary space power applications and advanced concepts for future space applications.

Energy Research Corporation (ERC) had 1993 R\&D expenditures of US\$1.15 million. The Fuel Cell Commercialization Group, a buyer's organization comprised of nearly 40 electric and gas utilities and non-utility generators, supports ERC. ERC was awarded a five year US $\$ 153$ million project by the US Department of Energy. The Department was to supply US\$ 84 million with the additional funding from other sources. ERC is currently focusing on 
the development of MCFC technology. In 1993, Fuel Cell Engineering Corporation, a subsidiary of ERC, was awarded a US\$27 million contract to construct and test a 2-MW MCFC direct fuel cell power plant in Santa Clara, California. Fuel Cell Engineering Corporation is working in conjunction with Flour Daniel throughout the project, which is sponsored by the City of Santa Clara, the Los Angeles Department of Water and Power, the National Rural Electric Cooperative Association, Sacramento Municipal Utility District, Southern California Edison Company, the City of Vernon, California, EPRI, and the U.S. Department of Energy. The R\&D center for ERC is Danbury, Connecticut. Recent R\&D activities have included coal-gas contaminant polishing and testing, carbonate fuel cell module design, ethanol and coal-gas powered fuel cells and new battery applications. The emphasis of the R\&D program has shifted towards production methods as ERC has moved toward commercialization of fuel-cell technologies. ERC has estimated total funding for its commercialization program at US\$250 million.

MC Power conducts R\&D on MCFC technology. It heads a commercialization team consisting of Stewart \& Stevenson, Bechtel Corporation, and the Institute of Gas Technology. Input on customer needs is provided by the Alliance to Commercialize Carbonate Technology, a users group of electric and gas utilities, independent power producers, gas pipeline companies, and industrial and commercial organizations. The primary feature of MCFC technology is the use of an internally rather than externally manifolded heat exchanger. MC Power has estimated it will spend US\$ 100 million over the next five years on fuel cells.

Westinghouse Electric Corporation is involved in the R\&D of SOFC technology. The Westinghouse program is aimed at commercialization of tubular SOFCs before the year 2000. To meet its commercialization goals Westinghouse has identified four required operating parameters: fuel cells must be able to operate reliably for five years, have a voltage degradation rate of less than $1 \%$ per thousand hours, be able to operate on natural gas, and cost less than $\$ 1500$ per $\mathrm{kW}$.

International Fuel Cells (IFC) has been involved in the R\&D of PAFC and MCFC. ONSI Corporation, a subsidiary of IFC, was formed to manufacture package, on-site fuel-cell power plants with electric ratings below one MW. The model PC-25A $200 \mathrm{~kW}$ system was the first commercially available on-site fuel-cell system. IFC has commercial alliances with Toshiba (equity partner), Ansaldo (equity partner), Enron, and Heavy Industries of Korea.

Allied Signal has been involved in SOFC R\&D. Under Department of Energy sponsorship, Allied Signal teamed with Argonne National Laboratory to fabricate stacks of several monolithic cells by techniques that roll thin uniform layers of the materials used to form ceramic structure.

EP Fuel Cells (formerly Energy Partners Inc.) produced a "green car" technology demonstration vehicle in the fall of 1993 . The vehicle is powered by a PEFC and has a sixty mile driving range with a top speed of $60 \mathrm{mph}$. 
Table 4.29 Fuel Cell Project List

\begin{tabular}{|c|c|c|c|c|}
\hline$\overline{\text { Project }}$ & $\begin{array}{l}\text { Funding } \\
\text { Source }\end{array}$ & Performer & Dates & Funding Level \\
\hline Various & $\begin{array}{l}\text { Department of } \\
\text { Energy }\end{array}$ & Various & $\begin{array}{l}1994 \\
1993\end{array}$ & $\begin{array}{l}51.8 \\
51.1\end{array}$ \\
\hline Various & NASA & Various & 1994 & NA \\
\hline Various & $\begin{array}{l}\text { Department of } \\
\text { Defense }\end{array}$ & Various & 1994 & 35.4 \\
\hline Various & $\begin{array}{l}\text { Fuel Cell } \\
\text { Commercial- } \\
\text { ization Group }\end{array}$ & $\begin{array}{l}\text { Energy } \\
\text { Research } \\
\text { Corporation }\end{array}$ & 1994-1998 & 69 \\
\hline Various & $\begin{array}{l}\text { Energy } \\
\text { Research } \\
\text { Corporation }\end{array}$ & $\begin{array}{l}\text { Energy } \\
\text { Research } \\
\text { Corporation }\end{array}$ & $\begin{array}{l}1993 \\
1992\end{array}$ & $\begin{array}{l}1.2 \\
1.5\end{array}$ \\
\hline Various & $\begin{array}{l}\text { Gas Research } \\
\text { Institute } \\
\text { (Cooperative } \\
\text { Member } \\
\text { Support) }\end{array}$ & Various & $\begin{array}{l}1996 \\
1995\end{array}$ & $\begin{array}{l}4.5(16.1) \\
3.85(12.1)\end{array}$ \\
\hline Various & $\begin{array}{l}\text { EPRI } \\
\text { (Cooperative } \\
\text { Member } \\
\text { support) }\end{array}$ & Various & 1994 & $6(6)$ \\
\hline Various & MC Power & MC Power & 1995-1999 & 30 \\
\hline Various & Westinghouse & Westinghouse & $\begin{array}{l}1993 \\
1992\end{array}$ & $\begin{array}{l}9.8^{*} \\
9.7^{*}\end{array}$ \\
\hline
\end{tabular}


Table 4.29 Continued.

\begin{tabular}{|l|l|l|l|l|}
\hline Project & $\begin{array}{l}\text { Funding } \\
\text { Source }\end{array}$ & Performer & Dates & $\begin{array}{l}\text { Funding Level } \\
\text { USS (million) }\end{array}$ \\
\hline $\begin{array}{l}\text { Thin Layers } \\
\text { SOFC }\end{array}$ & Allied Signal & Allied Signal & 1993 & DOE-funded \\
\hline $\begin{array}{l}\text { Green Car } \\
\text { Project }\end{array}$ & EP Fuel Cells & EP Fuel Cells & $1991-1993$ & 3.4 \\
\hline Various & H Power & H Power & NA & NA \\
\hline Various & $\begin{array}{l}\text { International } \\
\text { Fuel Cells }\end{array}$ & $\begin{array}{l}\text { International } \\
\text { Fuel Cells }\end{array}$ & 1993 & $3.5^{*}$ \\
\hline
\end{tabular}

* Estimated levels of expenditures

Advanced Gas Turbine R\&D in the U.S. was estimated at US\$ 520.5 million in 1994. The U.S. Department of Energy through its Advanced Turbine System (ATS) program, the Gas Research Institute (GRI), the Electric Power Research Institute (EPRI), and such private companies as General Electric, Westinghouse, Cooper Industries, and Solar Turbines provide the bulk of the advanced gas turbine R\&D funding (see table 4.30).

The advanced turbine system program of the Department of Energy had a 1994 budget of US $\$ 32$ million. The program has a total budget of US\$700 million through the year 2000 , of which 450 million is to be provided by the Department of Energy with an additional 250 million provided by cost-sharing with industrial applicants. The program focuses on producing gas turbines that have ultra high efficiency, environmental superiority, reduced cost, and greater fuel flexibility, while keeping the RAM of today's turbines.

The Gas Research Institute conducts a comprehensive program in natural gas issues. Its program objectives parallel those of the Department of Energy's ATS program. At least three gas turbine projects are in the GRI research plan. GRI is represented on the steering committee of the ATS program, thereby ensuring participation and expertise and that projects are cooperative and without duplicated effort.

EPRI conducts substantial R\&D on gas turbine systems. It uses effective member participation in its program development and planning, and its expertise covers a wide range of utility issues and technologies. EPRI is a member of the ATS steering committee.

General Electric Company (GE) was determined to be the worlds leading funder of advanced gas turbine R\&D. GE had revenued of US $\$ 40$ billion in 1993. Its total R\&D budget was estimated at slightly more than US\$ 2 billion (5\% of revenue). Gas turbines are sold within 
two divisions; marine and industrial engines and power generation. The marine and industrial division specializes in applications of aeroderivative engines for non-aviation uses. Applications include marine, industrial, and mechanical drive. GE power generation is the world's prime supplier of power generation equipment and systems. Its products include gas turbines from the small aeroderivative size to the large heavy duty application, and steam turbine, hydro, nuclear, and marine propulsion technologies. Total sales from the marine and industrial and the power generation groups were US\$13.3 billion in 1993. Estimated R\&D expenditures were US\$ 664 million. Considering the large proportion of sales within each division attributable to gas turbines, the percentage of total R\&D allocated to gas turbines is likely quite high. As a result, it was estimated that GE allocated slightly more than US\$ 440 million to advanced gas turbine R\&D. In addition, General Electric has majority or partial ownership in a variety of gas turbine companies throughout the selected countries. For example, it has 10\% ownership in European Gas Turbines (France and the UK) and recently became majority owner of Nuovo Pignone (Italy). Both of these companies are known to pursue advanced gas turbine R\&D of which portions are attributed to GE's total gas turbine R\&D budget. GE is involved in the Department of Energy's ATS program through a 4.6 million US\$ project.

GE introduced the MS9001F(9F) frame in October 1992. The 9F was the world's most powerful gas turbine at that time. Two F series gas turbines, utilized at Korea Electric Power Company's $1887 \mathrm{MW}$ combined cycle plant, achieved 55\% thermal efficiency with an output of $235 \mathrm{MW}$. In addition to efficiency and power output gains GE has focused on reduction of emission levels. In cooperation with European Gas Turbines, GE performed research regarding dry low $\mathrm{NO}_{\mathrm{X}}$ systems to reduce emissions levels for Frame 3 and 5 turbines. GE developed a new-design breech load fuel nozzle that reduced maintenance costs in the GE56001 and M57001 gas turbines that use water injection for $\mathrm{NO}_{\mathrm{x}}$ abatement. GE performed R\&D regarding the Speedtronic Mark V control system. The Mark V control system was developed for use with both steam and gas turbines.

Solar Turbines, a subsidiary of Caterpillar, Inc., is involved in the research and development of advanced gas turbines. Caterpillar, Inc. had total sales of US\$ 11.6 billion and total R\&D expenditures of US\$ 319 million in 1993. Solar Turbines sales were estimated at approximately $8 \%$ of total Caterpillar sales. R\&D expenditures for Solar Turbines were estimated at US\$ 20 million for 1993, of which $100 \%$ was assumed allocated to advanced gas turbine R\&D. Solar Turbines produces gas turbines for both power generation and mechanical drive applications. The gas turbine product line includes the Saturn (1 MW), Centaur (3.5-4.2 MW), Taurus (5.2-6.6 MW), and Mars (9.7-11.2 MW) models. Solar Turbines is involved in the Department of Energy's ATS program in a US\$ 2.4 million project.

The R\&D program of Solar Turbines was focused on low $\mathrm{NO}_{\mathbf{X}}$ combustion systems, primary surface recuperators, predictive emissions monitoring systems, materials, and heat exchangers. In 1992, Solar developed SoLoNO $\mathrm{X}$ dry, low, $\mathrm{NO}_{\mathbf{X}}$ combustion systems across its entire product line. Solar developed a unique design for the primary surface recuperator for several of the engine models in their product line. A product that monitors a variety of 
engine operating parameters and predicts $\mathrm{NO}_{\mathrm{x}}$ emissions was developed and released to the marketplace in 1992. Solar investigates such advanced materials as single-crystal superalloys, coatings, and non-metallics for use in their turbines. Solar researches the application of ceramic materials in hot section components for improved efficiency and emissions characteristics. In addition, ceramic materials form the basis of a research program focused on the development of a high pressure heat exchange system for heat recovery from corrosive, high-temperature gas streams. Both of the ceramic materials $R \& D$ programs are performed in cost share with the U.S. Department of Energy.

Westinghouse Electric Corporation is also involved in the R\&D of advanced gas turbines. The $501 \mathrm{G}$ announced in June 1994 has a power output of $230-\mathrm{MW}$, a simple cycle efficiency of $38.5 \%$ and a combined cycle efficiency of $58 \%$. Westinghouse had sales of approximately US $\$ 9$ billion in 1993. Gas turbines are products in the power generation division which had 1993 sales of US\$ 3.2 billion. R\&D expenditures of the power generation division were US\$ 59 million in 1993 . The $R \& D$ program of the power generation division was divided between six different areas one of which was gas turbines. The estimated gas turbine R\&D expenditures of Westinghouse were US\$9.8 million. Westinghouse participates in the Department of Energy's ATS program through a US\$ 4.5 million project.

Westinghouse, through teaming with Rolls Royce, Allied Signal Air Research, and CAE, was awarded an advanced development contract for the intercooled recuperated gas turbine engine system by the U.S. Navy Sea Systems Command Advanced Surface Machinery Program. Technology gained from this program applicable to the power generation sector include, increased efficiency leading to a 30\% fuel savings, increased power output, and enhanced reliability and maintainability. Westinghouse signed a 15-year agreement with Rolls Royce that covers technology transfer, joint development of combustion turbine technology, and marketing of combustion turbines and combined-cycle power plants. RollsRoyce will transfer aeroengine technology to Westinghouse for incorporation into existing and future industrial combustion turbine designs. Westinghouse will transfer selected steam turbine, combustion turbine, and combined cycle technologies to Rolls-Royce.

Westinghouse, Fiat-Avio, and Mitsubishi Heavy Industries (MHI) agreed to cooperate in joint-development programs for combustion turbines. Westinghouse and MHI jointly developed an advanced-technology combustion turbine, the 501F, that produces $153 \mathrm{MW}$. R\&D plans for the $501 \mathrm{~F}$ include incorporation of advances in materials, coatings, cooling, and aero-technologies that enhance both engine performance and reliability. Further R\&D is directed at development of a dry low $\mathrm{NO}_{\mathrm{X}}$ combustion system that will achieve single-digit $\mathrm{NO}_{\mathrm{X}}$ levels.

Cooper Rolls, a joint venture between Cooper Industries, Inc. and Rolls-Royce, supplies engines and gas turbines to the cogeneration market. Cooper had total sales of US\$ 6.3 billion in 1993. Gas turbines are a product of the petroleum and industrial equipment division of Cooper. Division sales were estimated at US\$1.6 billion and R\&D expenditures were estimated at US\$ 314 million. Gas turbines comprised a small proportion of the sales; therefore, the proportion of $R \& D$ devoted to gas turbine $R \& D$ was considered minimal. All 
contributions from Rolls Royce to R\&D performed by Cooper Rolls was considered part of the total Rolls Royce R\&D funding.

The goals of Cooper Rolls turbine R\&D include higher power output and reduced emissions. The aeroderivative RB211 has been upgraded resulting in a $8.6 \%$ power increase. A dry low emission combustion system reduced $\mathrm{NO}_{\mathrm{X}}$ and $\mathrm{CO}$ emissions by incorporating series-staged combustion with pre-mix, lean-burn technology.

Allison Gas Turbine (Allison) is involved in advanced gas turbine R\&D. Allison is participating in the Department of Energy's ATS program through a US\$ 4.7 million project. In 1992, Allison developed plans for two aggressive emission reduction programs. The first program was aimed at reducing dry $\mathrm{NO}_{\mathbf{x}}$ levels with minimal changes to the envelope of the proven $501 \mathrm{~K}$ engine. The program was to evaluate such approaches as fuel staging and minimal wall cooling with the goal of fielding a system for evaluation in 1994. The second program called for going to a large single-can combustor, without changing the shafting of the engine, to achieve low emission levels. Allison Engine Company was recently purchased from General Motors by Rolls Royce. As a result, all R\&D funding for advanced gas turbine R\&D was attributed to the U.K., not the U.S..

Table 4.30 Advanced Gas Turbines Project List for the United States

\begin{tabular}{|l|l|l|l|l|}
\hline Project & $\begin{array}{l}\text { Funding } \\
\text { Source }\end{array}$ & Performer & Dates & $\begin{array}{l}\text { Funding Level } \\
\text { US\$ (million) }\end{array}$ \\
\hline $\begin{array}{l}\text { Various } \\
\text { ATS Prog } \\
\text { Funding }\end{array}$ & $\begin{array}{l}\text { Department of } \\
\text { Energy }\end{array}$ & Various & 1994 & 32 \\
\hline Various & $\begin{array}{l}\text { GRI (Member } \\
\text { support) }\end{array}$ & Various & $1993-2000$ & 450 \\
\hline Various & EPRI & Various & NA & NA \\
\hline Various & Westinghouse & Same & 1993 & $2.1(4.5)$ \\
& & & 1992 & $9.8^{*}$ \\
\hline Various & $\begin{array}{l}\text { Cooper } \\
\text { Industries }\end{array}$ & Same & 1993 & $2.7^{*}$ \\
\hline
\end{tabular}


Table 4.30. Continued.

\begin{tabular}{|l|l|l|l|l|}
\hline Project & $\begin{array}{l}\text { Funding } \\
\text { Source }\end{array}$ & Performer & Dates & $\begin{array}{l}\text { Funding Level } \\
\text { USS (million) }\end{array}$ \\
\hline Various & $\begin{array}{l}\text { General } \\
\text { Electric }\end{array}$ & Same & 1993 & $442.4^{*}$ \\
& & & 1992 & $458^{*}$ \\
\hline Various & Solar Turbines & Same & 1994 & $20.2^{*}$ \\
\hline
\end{tabular}

* Estimated levels of expenditures 


\subsection{European Union}

In addition to the funding provided by governments of EU-member countries (Belgium, Denmark, France, Germany, Greece, Ireland, Italy, Luxembourg, Netherlands, Portugal, Spain, and the $\mathrm{UK}$ ) the EU itself also provides R\&D funding. A supernational governmental organization with limited powers accorded by its member nations, the EU does not have the policymaking power, revenue raising ability, or legal competence of the selected countries. Therefore, comparisons of EU data with those of the U.S. or other selected countries should consider this fact.

The EU had a substantial R\&D budget in 1994. Energy R\&D received approximately US\$ 491 million. As a percentage of total $R \& D$, EU funded energy $R \& D$ was among the highest, stressing the relative importance of energy $R \& D$ within the greater $R \& D$ program of the $E U$ (see Figure 4.32). Fuel-cell funding was at a high level. Multiple programs fund fuel cell R\&D projects, totaling, approximately 11.1 million US\$.

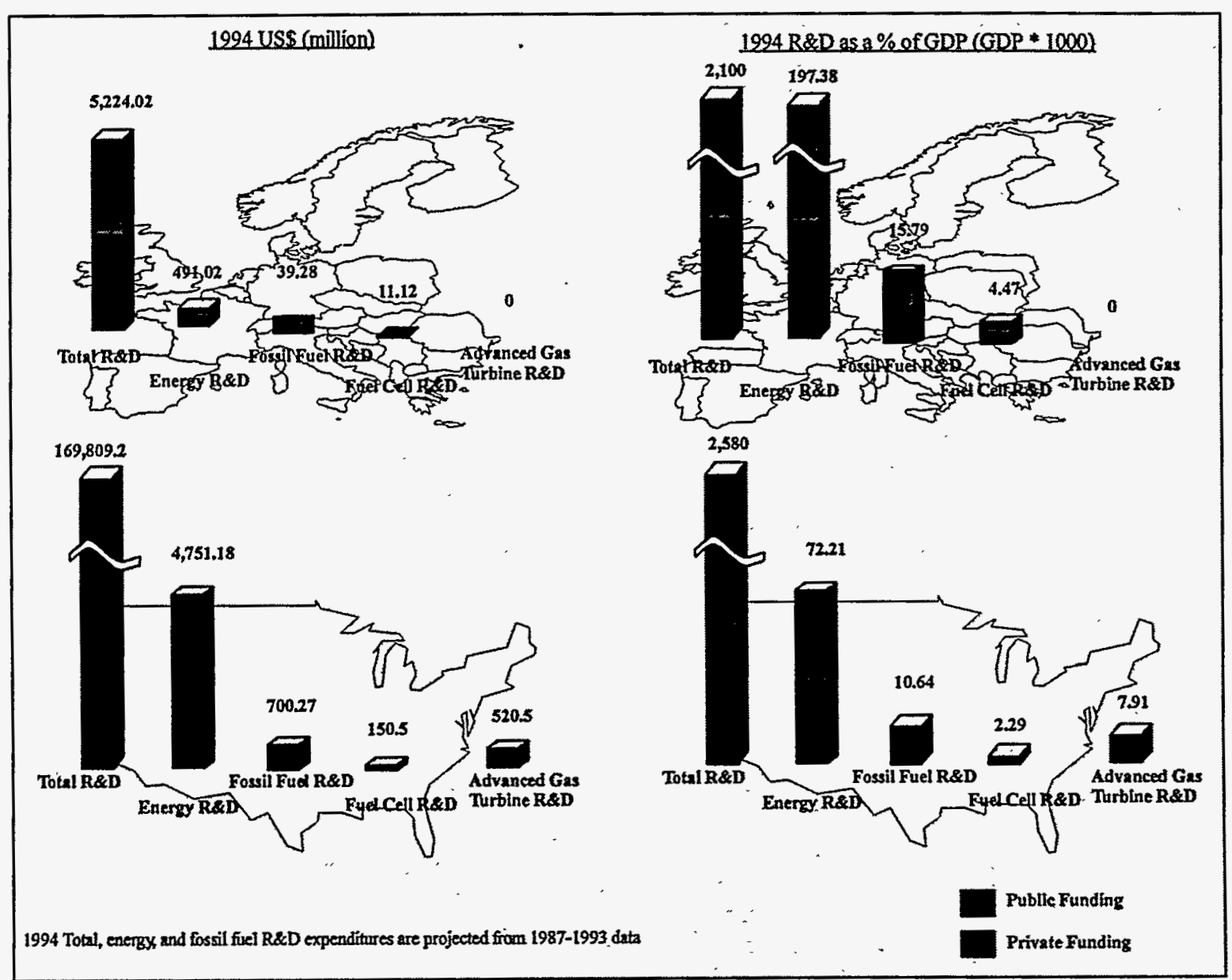

Figure 4.32. European Union R\&D Expenditures 


\subsubsection{R\&D Expenditures}

The EU supports R\&D projects at an estimated 1994 funding level of US\$ 5.2 billion. The EU's total R\&D budget was $2.1 \%$ of the EU GDP in 1994, less than the U.S. level of $2.6 \%$. Detailed past data for R\&D funding was not available for the EU; therefore, it was assumed that its $R \& D$ funding increased at the average of all the selected countries. Energy R\&D was supported at an estimated level of US\$ 491 million in 1994. Energy R\&D funding was considerably lower than that of the U.S.. EU energy R\&D as a percentage of GDP was $197.4 \%$ in 1994. At the 1994 level, the EU committed the fourth largest level of energy R\&D funding as a percentage of GDP of the selected countries. Energy R\&D was $9.4 \%$ of the total R\&D budget, much higher than the $2.8 \%$ U.S. level. The EU was a funder of fuel cell projects throughout Europe. It was estimated to have provided approximately US\$11.1 million in 1994. France, Germany, Italy, the Netherlands, and the U.K. were the only European countries that provided more funding for fuel cell R\&D.

\subsubsection{R\&D Organizational Structure}

EU project funding is provided by national governments, the EC (executive branch of the $\mathrm{EU})$, and industry, universities, and national laboratories.

- National governments. Commit $4 \%$ of their national R\&D budgets towards EU funding

- Industry, universities, and national laboratories provide matching funds for R\&D projects. R\&D partners are required to provide at least $50 \%$ of project cost.

The EC, in consultation with the scientific and business community, prepares research proposals that are reviewed and debated by the Council of Ministers and the European Parliaments. The Council of Ministers represents national political power in the EU; heads of state of the 12 member nations attend it's meetings. The European Parliament is the EU's legislative branch. Consultation with the scientific and business community involves discussions with science and technical research, european development of science and technology, and industrial research and development advisory committees.

\subsubsection{Energy R\&D and Sources of Electricity}

Nuclear technologies R\&D received the largest share of EU funding in 1993. Nuclear fusion received close to one half of the total EU R\&D budget, fission received another $34 \%$ (see Figure 4.33). The remainder of R\&D funding was spread between conservation, fossil fuels, 
and renewables, totaling approximately US\$100 million. Of the US\$100 million for nonnuclear R\&D, approximately $11 \%$ went for fuel-cell projects.

Data on the percentage of total electricity generated in the EU by fuel source was not available at the time of this report; however, data for many member countries can be found in the individual country reports in this section.

\subsubsection{Fuel Cell and Advanced Gas Turbine Projects}

The EU provides fuel-cell R\&D funding primarily through the following programs:

- Joule II

- Joule II Top Up

- Brite Euram

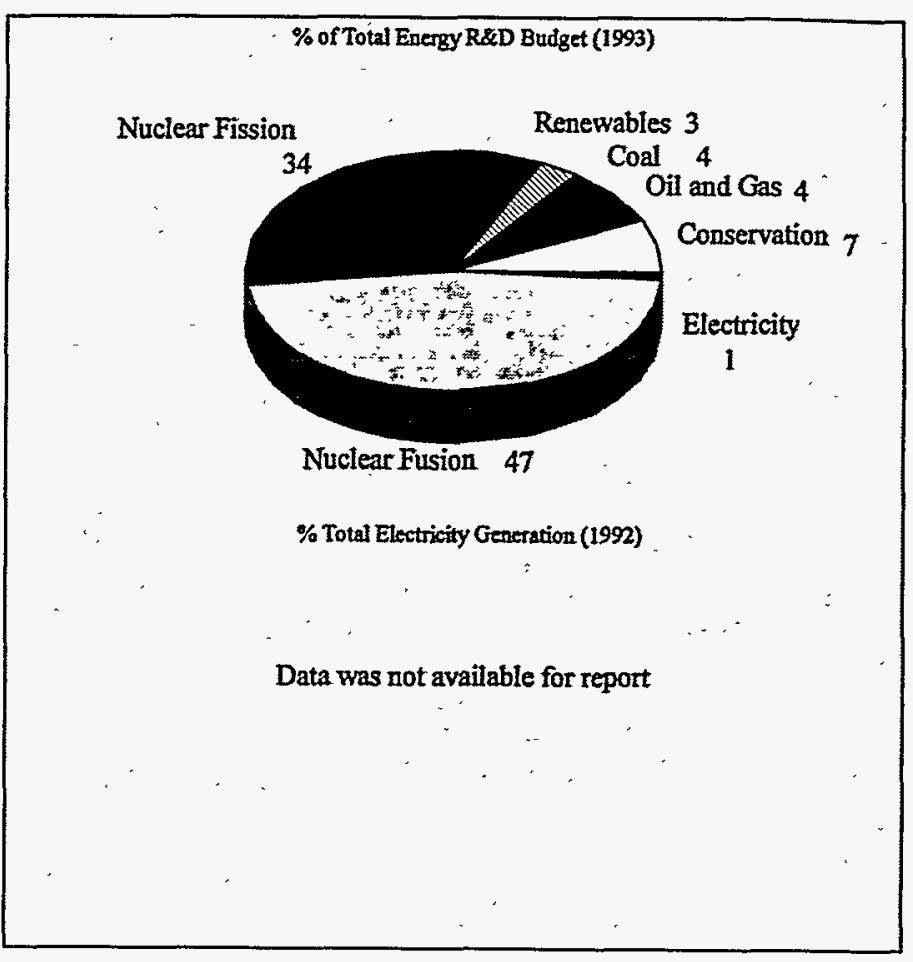

\section{Figure 4.33 European Union Energy R\&D and Electricity Generation Breakdown}

- Thermie

- European Quebec Hydrogen Hydro Pilot Project (EQHHPP)

These five primary programs, as well as specific projects, are listed in Table 4.31. The total fuel-cell funding level was estimated as the sum of the funding levels for each of the five programs. Funding levels listed for individual projects were considered part of the total funding level for each program and were not included in the estimation of overall EU fuel cell R\&D funding. EU fuel-cell funding was estimated at about US\$ 11.1 million in 1994. A separate report estimated funding levels at US\$ 60 million over the next five years (12 million US\$/year) (Michael. 1994). The highest level of funding is appropriated to polymer electrolyte fuel cell R\&D. At least five PEFC R\&D projects involving at least four countries are being partially funded by the EU. DMFC and MCFC projects also receive EU funding. Specific EU funded PAFC and SOFC R\&D projects were not identified.

EU funding for Advanced gas turbine R\&D was unavailable at the time of this writing. 
Table 4.31 Fuel Cell Project List

\begin{tabular}{|c|c|c|c|c|}
\hline Project & \begin{tabular}{|l|} 
Funding \\
Source
\end{tabular} & Performer & Dates & $\begin{array}{l}\text { Funding Level } \\
\text { USS (million) }\end{array}$ \\
\hline Joule II & EU & Various & 1992-1995 & 15 \\
\hline SOFC & & $\begin{array}{l}\text { British Gas, } \\
\text { TNO } \\
\text { (Netherlands) }\end{array}$ & & NA \\
\hline $\mathrm{MCFC}$ & & $\begin{array}{l}\text { ECN, Technical } \\
\text { University of } \\
\text { Delft } \\
\text { (Netherlands) }\end{array}$ & & NA \\
\hline Joule II Top Up & $\mathrm{EU}$ & Various & 1994-1997 & 8 \\
\hline Brite Euram & $\mathrm{EU}$ & Various & $1985-1997$ & 8 \\
\hline PEFC & & \begin{tabular}{|l} 
AEA \\
Technology \\
(UK), EA \\
Technology \\
(UK), Power \\
Gen (UK) \\
\end{tabular} & 1994-Present & 1.5 \\
\hline Thermie & EU & Various & 1986-1992 & 7 \\
\hline EQHHPP & $\mathrm{EU}$ & \begin{tabular}{|l|} 
EU Joint \\
Research Centre
\end{tabular} & $1992-1997$ & 45 \\
\hline PEFC & $\overline{E U}$ & $\overline{E C N}$ & 1993-present & 1 \\
\hline$\overline{\mathrm{PEFC}}$ & $\overline{E U}$ & Tecnarrs & 1993-present & $\overline{\mathrm{NA}}$ \\
\hline PEFC & $\overline{\mathrm{EU}}$ & KFA Julich & 1992-Present & $\overline{\mathrm{NA}}$ \\
\hline PEFC & $\overline{\mathrm{EU}}$ & Seimens & 1992-present & 1.75 \\
\hline$\overline{\text { DMFC }}$ & $\overline{E U}$ & $\begin{array}{l}\text { University of } \\
\text { Bonn }\end{array}$ & $\overline{\mathrm{NA}}$ & $\overline{\mathrm{NA}}$ \\
\hline$\overline{\text { DMFC }}$ & $\overline{\mathrm{EU}}$ & Siemens & $\overline{\mathrm{NA}}$ & $\overline{\mathrm{NA}}$ \\
\hline$\overline{D M F C}$ & $\overline{\mathrm{EU}}$ & $\begin{array}{l}\text { University of } \\
\text { Cork (Ireland) }\end{array}$ & $\overline{\mathrm{NA}}$ & $\overline{\mathrm{NA}}$ \\
\hline
\end{tabular}




\section{Conclusions}

The objective of the analysis was to identify and evaluate R\&D funding sources, levels, and trends in industrialized countries within the energy sector. Fuel cells and advanced gas turbines were the focal fossil-fuel technologies analyzed. The following countries, as well as the EU, were selected for review and analysis: Australia, Belgium, Canada, Denmark, Finland, France, Germany, Italy, Japan, Netherlands, Norway, Sweden, Switzerland, United Kingdom, and United States.

The U.S. and Japan are the world's R\&D leaders; together, their expenditures accounted for about two-thirds of the total R\&D expenditures of the EU and selected countries. Japan allocated almost three-quarters of the total energy R\&D funding of the selected countries (close to US $\$ 30.5$ billion). Japan also led the selected countries in funding of fossil fuel R\&D. In funding for fuel cell technology, Japan and the U.S. were the leaders, accounting for about 38 and $28 \%$, respectively, of total funding of the selected countries. $\mathrm{R} \& D$ funding for advanced gas turbines received the greatest private-level support in the U.S., UK, Japan, Sweden, Switzerland, and Germany. GE, Westinghouse, Rolls Royce, United Technologies, ABB, Seimens, Kawasaki, Mitsubishi, and Hitachi provided most of such funding.

Funding for fuel cell R\&D has escalated to an estimated level of more than US $\$ 500$ million throughout the world. The highest levels of such expenditures (in US\$ million) were provided by Japan (203.8), U.S. (150.5), Germany (53.1), Canada (32.1), and Italy (29.7). Japan's federal funding was provided under the New Sunshine program of the Ministry of International Trade and Industry, which is managed by NEDO and the Agency of Natural Resources and Energy. The following Japanese utilities provided a high level of support: Tokyo Electric Power Company (TEPCO), Kansai Electric Power Company, Chubu Electric Power Company, Tohoku Electric Power Company, and Tokyo Gas. Such private corporations as Fuji, Hitachi, Mitsubishi, Sanyo, and IHI also provided funding.

Most of the U.S. fuel-cell R\&D was federally funded through USDOE, DOD, and NASA in 1994. Private expenditures were provided by MC Power, International Fuel Cells, Energy Research Corporation, Westinghouse, Allied Signal, H Power, and EP Fuel Cells. Additional funding was allocated by the Electric Power Research Institute and the GRI. Canada's fuel cell R\&D program is concentrated within Ballard Power Systems, whose program focuses on develpoment of PEFCs for automotive applications. Germany has the largest European program, which is supported primarily by private companies, including Daimler Benz, BMW, Seimens, and Dornier. Italy has the second-largest European program, whose primary participants are Ansaldo, Fiat, and DeNora. The UK, Denmark, and the Netherlands also have ambitious fuel cell R\&D programs. The UK program is well developed; however, most projects involve either basic research or are 
partially supported by EU programs. As a result, the funding level (US $\$ 12$ million) does not accurately reflect the program size of at least 29 projects. Leading British participants are Johnson Matthley, British Gas, AEA Technology, CJB, VSEL, and Rolls Royce. The Dutch program focuses on development of MCFC and the work of the company BCN. Denmark, through ELSAM, Haldor Topsoe, and the Riso Research Center, has an advanced program investigating $\mathrm{MCFC}$ and SOFC.

Advanced gas turbine $R \& D$ funding is procured from public and private sources, however, the majority of the funding is provided by large, multinational corporations. Expenditures (US\$ million) were as follows: U.S. (520.5), UK (509.5), Japan (129), Sweden (116), Switzerland (116), and Germany (68.3). Funding data was available for many of the governments of the selected countries and estimates were prepared by K\&M that indicate the funds available within a corporation for advanced gas turbine R\&D. GE, the world's leader in advanced gas turbine R\&D, has a tremendous budget and financial resources available to back gas turbine R\&D. Rolls Royce was estimated to have the second largest budget for such funding, followed by ABB, United Technologies, Seimens, Kawasaki, European Gas Turbines, Solar Turbines, Hitachi, Westinghouse, and Mitsubishi. The U.S. and UK are home to three of the four and five of the ten largest gas turbine R\&D companies in the world. As a result, these two countries were determined to have the highest level of R\&D support for gas turbine $R \& D$. ABB R\&D funding was split between Sweden and Switzerland. Seimens, headquartered in Germany, provides funding for advanced gas turbine R\&D. Japanese advanced gas turbine expenditures include those of Hitachi, Kawasaki, Toshiba, IHI, and Mitsubishi. The governments of the United States, Japan, France, Germany, and the Netherlands supported advanced gas turbine R\&D at the highest levels. As a percentage of total advanced gas turbine $R \& D$, the federal governments of the Netherlands (60\%), France (22.9\%), Japan (19.5\%), and Germany (6.5\%) all supported R\&D at levels greater than the U.S. (6.2\%). 


\section{References}

OECD. 1993. Frascati Manual: Proposed Standard Practice for Surveys of Research and Experimental Development. Paris: Organization for Economic Co-operation and Development.

IEA. 1993. Energy Policies of IEA Countries: 1993 Review. Paris: International Energy Agency, Organization for Economic Co-operation and Development.

USDOE. 1993. Comprehensive Program Plan for Advanced Turbine Systems. July. Washington, D.C.: U.S. Department of Energy, Office of Fossil Energy, Office of Energy Efficiency and Renewable Energy.

Michael, P.D. 1994. European Fuel Cells R\&D Review. Final Report to the U.S. Department of Energy, September. Oxfordshire, UK: ETSU.

NEDO. 1993. Research and Development on Fuel Cell Power Generation Technology. FY 1993 Annual Report. Tokyo: New Energy and Industrial Technology Development Organization.

International Gas Turbine Institute. 1993. 1993 Technology Report Land, Sea \& Air. Atlanta, Georgia: The American Society of Mechanical Engineers. 


\section{Appendices}

Appendix A contains the R\&D database used throughout the analysis of R\&D expenditures. Appendices $B$ and $C$ present a list of the fuel cell and advanced gas turbine projects, respectively, within each of the industrialized countries. Appendix $D$ provides the exchange rates and purchasing power parities used during the assessment. Appendix $E$ lists additional resources of information relevant to the analysis of international R\&D efforts. 


\section{Appendix A. Research and Development Expenditures}

1994 Funding Levels

(ER's used)

\begin{tabular}{|c|c|c|c|c|c|c|c|c|c|}
\hline & \multicolumn{3}{|c|}{ Gross Domestic Product } & \multicolumn{6}{|l|}{ Total R\&D } \\
\hline Country & & illion) & $\%$ change & US\$ (million) & $\%$ change & $\%$ total & $\%$ GDP & Public (\%) & Private (\%) \\
\hline Australia & $S$ & 280.93 & $-1.26 \%$ & 4984.35 & $9.35 \%$ & $0.99 \%$ & $1.77 \%$ & $53.39 \%$ & $46.61 \%$ \\
\hline Belgium & $\$$ & 211.34 & $2.44 \%$ & 3562.13 & $6.75 \%$ & $0.71 \%$ & $1.69 \%$ & $27.08 \%$ & $72.92 \%$ \\
\hline Canada & $\$$ & 537.36 & $-1.44 \%$ & 6869.46 & $5.16 \%$ & $1.36 \%$ & $1.28 \%$ & $53.39 \%$ & $46.61 \%$ \\
\hline Denmark & $\overline{\$}$ & 137.70 & $1.63 \%$ & 2634.1 & $8.54 \%$ & $0.52 \%$ & $1.91 \%$ & $39.54 \%$ & $60.46 \%$ \\
\hline European Union & $\$$ & 248.76 & & 5224.02 & $7.09 \%$ & $1.04 \%$ & $2.10 \%$ & $50.00 \%$ & $50.00 \%$ \\
\hline Finland & $S$ & 70.04 & $-15.10 \%$ & 3188.31 & $14.10 \%$ & $0.63 \%$ & $4.55 \%$ & $26.76 \%$ & $73.24 \%$ \\
\hline France & $\$$ & $1,269.81$ & $1.54 \%$ & 36175.37 & $8.03 \%$ & $7.18 \%$ & $2.85 \%$ & $49.14 \%$ & $50.86 \%$ \\
\hline Germany & $\$$ & $1,789.98$ & $4.50 \%$ & 53470.18 & $6.44 \%$ & $10.61 \%$ & $2.99 \%$ & $39.85 \%$ & $60.15 \%$ \\
\hline Italy & 5 & 959.06 & $-3.26 \%$ & 16332.95 & $12.69 \%$ & $3.24 \%$ & $1.70 \%$ & $52.58 \%$ & $47.42 \%$ \\
\hline Japan & $s$ & $4,757.80$ & $12.86 \%$ & 163506.86 & $9.13 \%$ & $32.46 \%$ & $3.44 \%$ & $17.45 \%$ & $82.55 \%$ \\
\hline Netherlands & $\$$ & 317.59 & $2.88 \%$ & 6151.24 & $2.28 \%$ & $1.22 \%$ & $1.94 \%$ & $48.03 \%$ & $51.97 \%$ \\
\hline Norway & $\$$ & 102.44 & $-0.73 \%$ & 1967.38 & $4.69 \%$ & $0.39 \%$ & $1.92 \%$ & $58.34 \%$ & $41.66 \%$ \\
\hline Sweden & 5 & 173.59 & $-6.77 \%$ & 5466.99 & $5.31 \%$ & $1.09 \%$ & $3.15 \%$ & $41.45 \%$ & $58.55 \%$ \\
\hline Switzerland & $\$$ & 237.00 & $1.20 \%$ & 6622.56 & $4.79 \%$ & $1.31 \%$ & $2.79 \%$ & $27.16 \%$ & $72.84 \%$ \\
\hline U.K. & $\$$ & 927.01 & $-1.27 \%$ & 17809.98 & $5.02 \%$ & $3.54 \%$ & $1.92 \%$ & $38.01 \%$ & $61.99 \%$ \\
\hline U.S.A. & $\$$ & $6,579.47$ & $4.63 \%$ & 169809.17 & $4.07 \%$ & $33.71 \%$ & $2.58 \%$ & $47.56 \%$ & $52.44 \%$ \\
\hline Total & $\$$ & $18,599.88$ & & 503775.05 & & & & & \\
\hline
\end{tabular}

\section{Funding Levels}

(PPP's used)

\begin{tabular}{|c|c|c|c|c|c|c|c|c|}
\hline & Conversion Facto & & Total R\&D & & & & & \\
\hline Country & PPP & ER & US\$ (million) & $\%$ change & $\%$ total & $\%$ GDP & Public (\%) & Private (\%) \\
\hline Australia & 1.33 & 1.35 & $5,059.30$ & $9.35 \%$ & $1.25 \%$ & $1.80 \%$ & $53.39 \%$ & $46.61 \%$ \\
\hline Belgium & 38.8 & 32.8 & $3,011.29$ & $6.75 \%$ & $0.75 \%$ & $1.42 \%$ & $27.08 \%$ & $72.92 \%$ \\
\hline Canada & 1.25 & 1.38 & $7,583.88$ & $5.16 \%$ & $1.88 \%$ & $1.41 \%$ & $53.39 \%$ & $46.61 \%$ \\
\hline Denmark & 9.3 & 6.26 & $1,773.06$ & $8.54 \%$ & $0.44 \%$ & $1.29 \%$ & $39.54 \%$ & $60.46 \%$ \\
\hline European Union & 1 & 1 & $5,224.02$ & $7.09 \%$ & $1.30 \%$ & $2.10 \%$ & $50.00 \%$ & $50.00 \%$ \\
\hline Finland & 6.46 & 5.24 & $2,586.18$ & $14.10 \%$ & $0.64 \%$ & $3.69 \%$ & $26.76 \%$ & $73.24 \%$ \\
\hline France & 6.56 & 5.44 & $29,999.09$ & $8.03 \%$ & $7.44 \%$ & $2.36 \%$ & $49.14 \%$ & $50.86 \%$ \\
\hline Germany & 2.13 & $\overline{1.6}$ & $40,165.39$ & $6.44 \%$ & $9.96 \%$ & $2.24 \%$ & $39.85 \%$ & $60.15 \%$ \\
\hline Italy & 1523 & 1595 & $17,105.09$ & $12.69 \%$ & $4.24 \%$ & $1.78 \%$ & $52.58 \%$ & $47.42 \%$ \\
\hline Japan & 187 & 99.75 & $87,218.23$ & $9.13 \%$ & $21.63 \%$ & $1.83 \%$ & $17.45 \%$ & $82.55 \%$ \\
\hline Netherlands & 2.17 & 1.79 & $5,074.06$ & $2.28 \%$ & $1.26 \%$ & $1.60 \%$ & $48.03 \%$ & $51.97 \%$ \\
\hline Norway & 9.22 & 6.95 & $1,483.00$ & $4.69 \%$ & $0.37 \%$ & $1.45 \%$ & $58.34 \%$ & $41.66 \%$ \\
\hline Sweden & 10.1 & 7.78 & $4,211.21$ & $5.31 \%$ & $1.04 \%$ & $2.43 \%$ & $41.45 \%$ & $58.55 \%$ \\
\hline Switzerland & 2.22 & 1.54 & $4,594.03$ & $4.79 \%$ & $1.14 \%$ & $1.94 \%$ & $27.16 \%$ & $72.84 \%$ \\
\hline U.K. & 0.64 & 0.66 & $\begin{array}{ll}S \quad 18,366.54 \\
\end{array}$ & $5.02 \%$ & $4.55 \%$ & $1.98 \%$ & $38.01 \%$ & $61.99 \%$ \\
\hline U.S.A. & i) & 1 & $\begin{array}{ll}\mathbf{S} & 169,809.17 \\
\end{array}$ & $4.07 \%$ & $42.11 \%$ & $2.58 \%$ & $47.56 \%$ & $52.44 \%$ \\
\hline Total & & & \begin{tabular}{|l|l} 
S & $403,263.55$ \\
\end{tabular} & & & & & \\
\hline
\end{tabular}




\section{Funding Levels \\ (ER's used)}

\begin{tabular}{|c|c|c|c|c|c|c|c|c|c|c|c|}
\hline \multirow[b]{2}{*}{ Country } & \multicolumn{3}{|c|}{ Gross Domestic Product } & \multicolumn{8}{|c|}{ Energy R\&D } \\
\hline & & illion) & $\%$ change & & (million) & $\%$ change & $\%$ total & $\%$ total R\&D & $\%$ GDP 1000 & Public (\%) & Private (\%) \\
\hline Australia & $\mathbf{S}$ & 280.93 & $-1.26 \%$ & $\mathbf{S}$ & 167.66 & $6.54 \%$ & $0.40 \%$ & $3.36 \%$ & $59.68 \%$ & $53.39 \%$ & $46.61 \%$ \\
\hline Belgium & $\$$ & 211.34 & $2.44 \%$ & $\$$ & 117.94 & $-15.84 \%$ & $0.28 \%$ & $3.31 \%$ & $55.81 \%$ & $27.08 \%$ & $72.92 \%$ \\
\hline Canada & $s$ & 537.36 & $-1.44 \%$ & $S$ & 945.21 & $-3.92 \%$ & $2.27 \%$ & $13.76 \%$ & $175.90 \%$ & $27.40 \%$ & $72.60 \%$ \\
\hline Denmark & 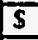 & 137.70 & $1.63 \%$ & 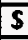 & 139.24 & $14.14 \%$ & $0.33 \%$ & $5.29 \%$ & $101.12 \%$ & $39.54 \%$ & $60.46 \%$ \\
\hline European Union & $S$ & 248.76 & & 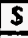 & 491.02 & $-1.95 \%$ & $1.18 \%$ & $9.40 \%$ & $197.39 \%$ & $50.00 \%$ & $50.00 \%$ \\
\hline Finland & $\mathbf{S}$ & 70.04 & $-15.10 \%$ & $\$$ & 205.96 & $4.95 \%$ & $0.49 \%$ & $6.46 \%$ & $294.06 \%$ & $20.45 \%$ & $79.55 \%$ \\
\hline France & 5 & $1,269.81$ & $1.54 \%$ & 5 & $1,137.53$ & $-2.89 \%$ & $2.73 \%$ & $3.14 \%$ & $89.58 \%$ & $49.14 \%$ & $50.86 \%$ \\
\hline Germany & $\$$ & $1,789.98$ & $4.50 \%$ & $\$$ & $1,005.35$ & $-7.99 \%$ & $2.42 \%$ & $1.88 \%$ & $56.17 \%$ & $39.85 \%$ & $60.15 \%$ \\
\hline Italy & $\mathbf{s}$ & 959.06 & $-3.26 \%$ & 5 & 636.80 & $-13.96 \%$ & $1.53 \%$ & $3.90 \%$ & $66.40 \%$ & $52.58 \%$ & $47.42 \%$ \\
\hline Japan & $S$ & $4,757.80$ & $12.86 \%$ & $\$$ & $30,493.65$ & $5.68 \%$ & $73.26 \%$ & $18.65 \%$ & $640.92 \%$ & $17.45 \%$ & $82.55 \%$ \\
\hline Netherlands & 5 & 317.59 & $2.88 \%$ & $s$ & 310.55 & $-4.70 \%$ & $0.75 \%$ & $5.05 \%$ & $97.78 \%$ & $48.03 \%$ & $51.97 \%$ \\
\hline Norway & $\$$ & 102.44 & $-0.73 \%$ & 5 & 93.60 & $3.48 \%$ & $0.22 \%$ & $4.76 \%$ & $91.37 \%$ & $58.34 \%$ & $41.66 \%$ \\
\hline Sweden & 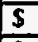 & 173.59 & $-6.77 \%$ & $S$ & 172.06 & $-2.96 \%$ & $0.41 \%$ & $3.15 \%$ & $99.12 \%$ & $41.45 \%$ & $58.55 \%$ \\
\hline Switzerland & $S$ & 237.00 & $1.20 \%$ & $S$ & 547.00 & $4.00 \%$ & $1.31 \%$ & $8.26 \%$ & $230.80 \%$ & $27.16 \%$ & $72.84 \%$ \\
\hline U.K. & 5 & 927.01 & $-1.27 \%$ & $s$ & 408.07 & $-14.31 \%$ & $0.98 \%$ & $2.29 \%$ & $44.02 \%$ & $38.01 \%$ & $61.99 \%$ \\
\hline U.S.A. & 5 & $6,579.47$ & $4.63 \%$ & $s$ & $4,751.18$ & $-4.32 \%$ & $11.41 \%$ & $2.80 \%$ & $72.21 \%$ & $47.56 \%$ & $52.44 \%$ \\
\hline Total & $\$$ & $18,599.88$ & & $\$$ & $41,622.82$ & & & & & & \\
\hline
\end{tabular}

1994 Funding Levels

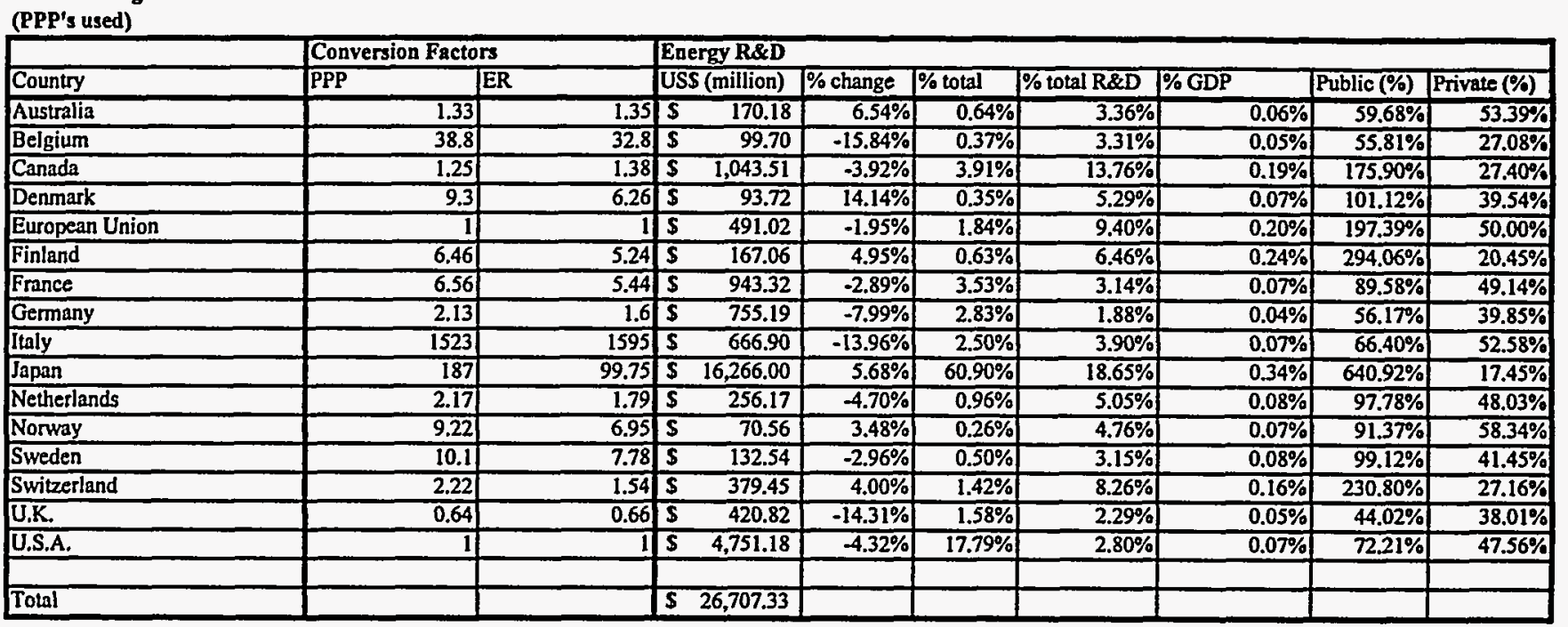


1994 Funding Levels

(ER's used)

\begin{tabular}{|c|c|c|c|c|c|c|c|c|c|c|}
\hline \multirow[b]{2}{*}{ Country } & \multicolumn{3}{|c|}{ Gross Domestic Product } & \multicolumn{7}{|c|}{ Fossil Fuel R\&D } \\
\hline & & illion) & $\%$ change & USS (million) & $\%$ change & $\%$ total & $\%$ total R\&D & $\%$ GDP & Public (\%) & Private (\%) \\
\hline Australia & $\mathbf{S}$ & 280.93 & $-1.26 \%$ & 41.55 & $-7.24 \%$ & $1.02 \%$ & $0.83 \%$ & $14.79 \%$ & $53.39 \%$ & $46.61 \%$ \\
\hline Belgium & $\mathbf{s}$ & 211.34 & $2.44 \%$ & 117.94 & $40.86 \%$ & $2.89 \%$ & $3.31 \%$ & $55.81 \%$ & $27.08 \%$ & $72.92 \%$ \\
\hline Canada & $\$$ & 537.36 & $-1.44 \%$ & 285.33 & $-10.34 \%$ & $7.00 \%$ & $4.15 \%$ & $53.10 \%$ & $27.40 \%$ & $72.60 \%$ \\
\hline Denmark & $\$$ & 137.70 & $1.63 \%$ & 25.28 & $24.96 \%$ & $0.62 \%$ & $0.96 \%$ & $18.36 \%$ & $39.54 \%$ & $60.46 \%$ \\
\hline European Union & $\$$ & 248.76 & & 39.28 & & $0.96 \%$ & $0.75 \%$ & $15.79 \%$ & $50.00 \%$ & $50.00 \%$ \\
\hline Finland & $\mathbf{S}$ & 70.04 & $-15.10 \%$ & 24.88 & $10.60 \%$ & $0.61 \%$ & $0.78 \%$ & $35.52 \%$ & $20.45 \%$ & $79.55 \%$ \\
\hline France & $\$$ & $1,269.81$ & $1.54 \%$ & 76.67 & $-5.58 \%$ & $1.88 \%$ & $0.21 \%$ & $6.04 \%$ & $49.14 \%$ & $50.86 \%$ \\
\hline Germany & $\$$ & $1,789.98$ & $4.50 \%$ & 73.44 & $-25.34 \%$ & $1.80 \%$ & $0.14 \%$ & $4.10 \%$ & $39.85 \%$ & $60.15 \%$ \\
\hline Italy & $\$$ & 959.06 & $-3.26 \%$ & 184.67 & & $4.53 \%$ & $1.13 \%$ & $19.26 \%$ & $52.58 \%$ & $47.42 \%$ \\
\hline Japan & $\$$ & $4,757.80$ & $12.86 \%$ & 2368.97 & $1.54 \%$ & $58.13 \%$ & $1.45 \%$ & $49.79 \%$ & $17.45 \%$ & $82.55 \%$ \\
\hline Netherlands & $\$$ & 317.59 & $2.88 \%$ & 24.77 & $-3.29 \%$ & $0.61 \%$ & $0.40 \%$ & $7.80 \%$ & $48.03 \%$ & $51.97 \%$ \\
\hline Norway & $\$$ & 102.44 & $-0.73 \%$ & 22.45 & $-7.77 \%$ & $0.55 \%$ & $1.14 \%$ & $21.92 \%$ & $58.34 \%$ & $41.66 \%$ \\
\hline Sweden & $\$$ & 173.59 & $-6.77 \%$ & 0.96 & $-50.51 \%$ & $0.02 \%$ & $0.02 \%$ & $0.55 \%$ & $41.45 \%$ & $58.55 \%$ \\
\hline Switzerland & $\$$ & 237.00 & $1.20 \%$ & 47.79 & $12.86 \%$ & $1.17 \%$ & $0.72 \%$ & $20.16 \%$ & $27.16 \%$ & $72.84 \%$ \\
\hline U,K. & $\$$ & 927.01 & $-1.27 \%$ & 40.79 & $-14.34 \%$ & $1.00 \%$ & $0.23 \%$ & $4.40 \%$ & $38.01 \%$ & $61.99 \%$ \\
\hline U.S.A. & $\$$ & $6,579.47$ & $4.63 \%$ & 700.28 & $-22.65 \%$ & $17.18 \%$ & $0.41 \%$ & $10.64 \%$ & $47.56 \%$ & $52.44 \%$ \\
\hline & & & & & & & & & & \\
\hline Total & $\$$ & $18,399.88$ & & 4075.05 & & & & & & \\
\hline
\end{tabular}

1994 Funding Levels

(PPP's used)

\begin{tabular}{|c|c|c|c|c|c|c|c|c|c|}
\hline \multirow[b]{2}{*}{ Country } & \multicolumn{2}{|l|}{ Conversion Factors } & \multicolumn{7}{|c|}{ Fossil Fuel R\&D } \\
\hline & $\overline{\mathrm{PPP}}$ & TER & USS (million) & $\%$ change & $\%$ total & $\%$ total R\&D & $\%$ GDP & Public (\%) & Private (\%) \\
\hline Australia & 1.33 & 1.35 & 42.17 & $-7.24 \%$ & $1.44 \%$ & $0.83 \%$ & $0.02 \%$ & $14.79 \%$ & $53.39 \%$ \\
\hline Belgium & 38.8 & 32.8 & 99.70 & $40.86 \%$ & $3.41 \%$ & $3.31 \%$ & $0.05 \%$ & $55.81 \%$ & $27.08 \%$ \\
\hline Canada & 1.25 & 1.38 & 315.00 & $-10.34 \%$ & $10.78 \%$ & $4.15 \%$ & $0.06 \%$ & $53.10 \%$ & $27.40 \%$ \\
\hline Denmark & 9.3 & 6.26 & $\overline{17.02}$ & $24.96 \%$ & $0.58 \%$ & $0.96 \%$ & $0.01 \%$ & $18.36 \%$ & $39.54 \%$ \\
\hline European Union & II & $\bar{l}$ & 39.28 & $0.00 \%$ & $1.34 \%$ & $0.75 \%$ & $0.02 \%$ & $15.79 \%$ & $50.00 \%$ \\
\hline Finland & 6.46 & 5.24 & 20.18 & $10.60 \%$ & $0.69 \%$ & $0.78 \%$ & $0.03 \%$ & $35.52 \%$ & $20.45 \%$ \\
\hline France & 6.56 & $\overline{5.44}$ & 63.58 & $-5.58 \%$ & $2.18 \%$ & $0.21 \%$ & $0.01 \%$ & $6.04 \%$ & $49.14 \%$ \\
\hline Germany & 2.13 & 1.6 & 55.17 & $-25.34 \%$ & $1.89 \%$ & $0.14 \%$ & $0.00 \%$ & $4.10 \%$ & $39.85 \%$ \\
\hline Italy & 1523 & 1595 & 193.40 & $0.00 \%$ & $6.62 \%$ & $1.13 \%$ & $0.02 \%$ & $19.26 \%$ & $52.58 \%$ \\
\hline Japan & 187 & 99.75 & \begin{tabular}{|l|l|}
$\$$ & $1,263.66$ \\
\end{tabular} & $1.54 \%$ & $43.24 \%$ & $1.45 \%$ & $0.03 \%$ & $49.79 \%$ & $17.45 \%$ \\
\hline Netherlands & 2.17 & 1.79 & 20.43 & $-3.29 \%$ & $0.70 \%$ & $0.40 \%$ & $0.01 \%$ & $7.80 \%$ & $48.03 \%$ \\
\hline Norway & 9.22 & 6.95 & 16.92 & $-7.77 \%$ & $0.58 \%$ & $1.14 \%$ & $0.02 \%$ & $21.92 \%$ & $58.34 \%$ \\
\hline Sweden & 10.1 & 7.78 & 0.74 & $-50.51 \%$ & $0.03 \%$ & $0.02 \%$ & $0.00 \%$ & $0.55 \%$ & $41.45 \%$ \\
\hline Switzerland & 2.22 & 1.54 & 33.15 & $12.86 \%$ & $1.13 \%$ & $0.72 \%$ & $0.01 \%$ & $20.16 \%$ & $27.16 \%$ \\
\hline $\mathrm{U}, \mathrm{K}$. & 0.64 & 0.66 & 42.06 & $-14.34 \%$ & $1.44 \%$ & $0.23 \%$ & $0.00 \%$ & $4.40 \%$ & $38.01 \%$ \\
\hline U.S.A. & 1 & I & 700.28 & $-22.65 \%$ & $23.96 \%$ & $0.41 \%$ & $0.01 \%$ & $10.64 \%$ & $47.56 \%$ \\
\hline & & & & & & & & & \\
\hline Total & & & $\begin{array}{ll} & 2,922.76\end{array}$ & & & & & & \\
\hline
\end{tabular}


1994 Funding Levels

(ER's used)

\begin{tabular}{|c|c|c|c|c|c|c|c|c|c|c|c|}
\hline \multirow[b]{2}{*}{ Country } & \multicolumn{3}{|c|}{ Gross Domestic Product } & \multicolumn{8}{|c|}{ Fuel Cell R\&D } \\
\hline & & illion) & $\%$ change & & million) & $\%$ change & $\%$ total & $\%$ total R\&D & $\%$ GDP & Public (\%) & Private (\%) \\
\hline Australia & 5 & 280.93 & $-1.26 \%$ & $\$$ & 1.00 & na & $0.18 \%$ & $0.02 \%$ & $0.36 \%$ & $100.00 \%$ & $0.00 \%$ \\
\hline Belgium & $\$$ & 211.34 & $2.44 \%$ & $\$$ & 2.25 & na & $0.41 \%$ & $0.06 \%$ & $1.06 \%$ & $0.00 \%$ & $100.00 \%$ \\
\hline Canada & $\$$ & 537.36 & $-1.44 \%$ & $\$$ & 32.06 & na & $5.91 \%$ & $0.47 \%$ & $5.97 \%$ & $2.00 \%$ & $98.00 \%$ \\
\hline Denmark & $\overline{\$}$ & 137.70 & $1.63 \%$ & $\$$ & 8.48 & na & $1.56 \%$ & $0.32 \%$ & $6.16 \%$ & $11.79 \%$ & $88.21 \%$ \\
\hline European Union & $\$$ & 248.76 & & $\$$ & 11.12 & na & $2.05 \%$ & $0.21 \%$ & $4.47 \%$ & $100.00 \%$ & $0.00 \%$ \\
\hline Finland & $\$$ & 70.04 & $-15.10 \%$ & $s$ & 0.50 & na & $0.09 \%$ & $0.02 \%$ & $0.71 \%$ & $0.00 \%$ & $100.00 \%$ \\
\hline France & $\mathbf{S}$ & $1,269.81$ & $1.54 \%$ & $\mathbf{s}$ & 12.04 & na & $2.22 \%$ & $0.03 \%$ & $0.95 \%$ & $85.00 \%$ & $15.00 \%$ \\
\hline Germany & 5 & $1,789.98$ & $4.50 \%$ & $\$$ & 53.12 & na & $9.79 \%$ & $0.10 \%$ & $2.97 \%$ & $13.46 \%$ & $86.54 \%$ \\
\hline Italy & $\$$ & 959.06 & $-3.26 \%$ & $\$$ & 29.67 & na & $5.47 \%$ & $0.18 \%$ & $3.09 \%$ & $31.08 \%$ & $68.92 \%$ \\
\hline Japan & $\$$ & $4,757.80$ & $12.86 \%$ & $\$$ & 203.81 & na & $37.56 \%$ & $0.12 \%$ & $4.28 \%$ & $33.35 \%$ & $66.65 \%$ \\
\hline Netherlands & $\$$ & 317.59 & $2.88 \%$ & $\$$ & 16.20 & na & $2.99 \%$ & $0.26 \%$ & $5.10 \%$ & $68.97 \%$ & $31.03 \%$ \\
\hline Norway & $\$$ & 102.44 & $-0.73 \%$ & $\$$ & 3.86 & na & $0.71 \%$ & $0.20 \%$ & $3.77 \%$ & $22.36 \%$ & $77.64 \%$ \\
\hline Sweden & $\$$ & 173.59 & $-6.77 \%$ & 5 & 3.00 & na & $0.55 \%$ & $0.05 \%$ & $1.73 \%$ & $0.00 \%$ & $100.00 \%$ \\
\hline Switzerland & $\$$ & 237.00 & $1.20 \%$ & $\$$ & 3.00 & na & $0.55 \%$ & $0.05 \%$ & $1.27 \%$ & 33.33\% & $66.67 \%$ \\
\hline U.K. & 5 & 927.01 & $-1.27 \%$ & $\bar{s}$ & 12.01 & na & $2.21 \%$ & $0.07 \%$ & $1.30 \%$ & $2.91 \%$ & $97.09 \%$ \\
\hline U.S.A. & 5 & $6,579.47$ & $4.63 \%$ & $s$ & 150.48 & na & $27.73 \%$ & $0.09 \%$ & $2.29 \%$ & $57.96 \%$ & $42.04 \%$ \\
\hline & & & & & & & & & & & \\
\hline Total & $\$$ & $18,599.88$ & & $\$$ & 542.60 & & & & & & \\
\hline
\end{tabular}

1994 Funding Levels

(PPP's used)

\begin{tabular}{|c|c|c|c|c|c|c|c|c|c|c|}
\hline \multirow[b]{2}{*}{ Country } & \multicolumn{2}{|c|}{ Conversion Factors } & \multicolumn{8}{|c|}{ Fuel Cell R\&D } \\
\hline & $\overline{P P P}$ & ER & $\overline{U S}$ & (million) & $\%$ change & $\%$ total & $\%$ total R\&D & $\%$ GDP & Public (\%) & Private (\%) \\
\hline Australia & 1.33 & 1.35 & $\$$ & 1.02 & na & $0.24 \%$ & $0.02 \%$ & $0.00 \%$ & $0.36 \%$ & $100.00 \%$ \\
\hline Belgium & 38.8 & 32.8 & $\bar{s}$ & 1.90 & na & $0.44 \%$ & $0.06 \%$ & $0.00 \%$ & $1.06 \%$ & $0.00 \%$ \\
\hline Canada & 1.25 & 1.38 & $\$$ & 35.39 & na & $8.26 \%$ & $0.47 \%$ & $0.01 \%$ & $5.97 \%$ & $2.00 \%$ \\
\hline Denmark & 9.3 & 6.26 & $\$$ & 5.71 & na & $1.33 \%$ & $0.32 \%$ & $0.00 \%$ & $6.16 \%$ & $11.79 \%$ \\
\hline European Union & 1 & 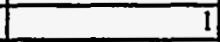 & 5 & 11.12 & na & $2.59 \%$ & $0.21 \%$ & $0.00 \%$ & $4.47 \%$ & $100.00 \%$ \\
\hline Finland & 6.46 & 5.24 & 5 & 0.41 & na & $0.09 \%$ & $0.02 \%$ & $0.00 \%$ & $0.71 \%$ & $0.00 \%$ \\
\hline France & 6.56 & 5.44 & $\$$ & 9.98 & na & $2.33 \%$ & $0.03 \%$ & $0.00 \%$ & $0.95 \%$ & $85.00 \%$ \\
\hline Germany & 2.13 & 1.6 & 5 & 39.90 & na & $9.31 \%$ & $0.10 \%$ & $0.00 \%$ & $2.97 \%$ & $13.46 \%$ \\
\hline Italy & 1523 & 1595 & 5 & 31.07 & na & $7.25 \%$ & $0.18 \%$ & $0.00 \%$ & $3.09 \%$ & $31.08 \%$ \\
\hline Japan & 187 & 99.75 & 5 & 108.72 & na & $25.36 \%$ & $0.12 \%$ & $0.00 \%$ & $4.28 \%$ & $33.35 \%$ \\
\hline Netherlands & 2.17 & 1.79 & $s$ & 13.36 & na & $3.12 \%$ & $0.26 \%$ & $0.00 \%$ & $5.10 \%$ & $68.97 \%$ \\
\hline Norway & 9.22 & 6.95 & $\$$ & 2.91 & na & $0.68 \%$ & $0.20 \%$ & $0.00 \%$ & $3.77 \%$ & $22.36 \%$ \\
\hline Sweden & 10.1 & 7.78 & $\$$ & 2.31 & na & $0.54 \%$ & $0.05 \%$ & $0.00 \%$ & $1.73 \%$ & $0.00 \%$ \\
\hline Switzerland & 2.22 & 1.54 & 5 & 2.08 & na & $0.49 \%$ & $0.05 \%$ & $0.00 \%$ & $1.27 \%$ & $33.33 \%$ \\
\hline U.K. & 0.64 & 0.66 & 5 & 12.39 & na & $2.89 \%$ & $0.07 \%$ & $0.00 \%$ & $1.30 \%$ & $2.91 \%$ \\
\hline U.S.A. & 1 & 1 & $S$ & 150.48 & na & $35.10 \%$ & $0.09 \%$ & $0.00 \%$ & $2.29 \%$ & $57.96 \%$ \\
\hline & & & & & & & & & & \\
\hline Total & & & s & 428.75 & & & & & & \\
\hline
\end{tabular}


1994 Funding Levels

(ER's used)

\begin{tabular}{|c|c|c|c|c|c|c|c|c|c|c|c|}
\hline & & Domestic & Product & & dvanced Ga & s Turbine $\mathrm{F}$ & $\& D$ & & & & \\
\hline Country & & billion) & $\%$ change & & S\$ (million) & $\%$ change & $\%$ total & $\%$ total R\&D & $\%$ GDP & Public (\%) & Private (\%) \\
\hline Australia & 5 & 280.93 & $-1.26 \%$ & $s$ & $\therefore$ & na & $0.00 \%$ & $0.00 \%$ & $0.00 \%$ & $0.00 \%$ & $100.00 \%$ \\
\hline Belgium & Is & 211.34 & $2.44 \%$ & $S$ & - & na & $0.00 \%$ & $0.00 \%$ & $0.00 \%$ & $0.00 \%$ & $100.00 \%$ \\
\hline Canada & s & 537.36 & $-1.44 \%$ & s & 0.08 & na & $0.01 \%$ & $0.00 \%$ & $0.01 \%$ & $0.00 \%$ & $100.00 \%$ \\
\hline Denmark & $s$ & 137.70 & $1.63 \%$ & 5 & - & na & $0.00 \%$ & $0.00 \%$ & $0.00 \%$ & $0.00 \%$ & $100.00 \%$ \\
\hline European Union & 5 & 248.76 & & $s$ & - & na & $0.00 \%$ & $0.00 \%$ & $0.00 \%$ & $0.00 \%$ & $100.00 \%$ \\
\hline Finland & $\$$ & 70.04 & $-15.10 \%$ & $s$ & - & na & $0.00 \%$ & $0.00 \%$ & $0.00 \%$ & $0.00 \%$ & $100.00 \%$ \\
\hline France & $\$$ & $1,269.81$ & $1.54 \%$ & 5 & 22.90 & na & $1.54 \%$ & $0.06 \%$ & $1.80 \%$ & $22.92 \%$ & $77.08 \%$ \\
\hline Germany & $\$$ & $1,789.98$ & $4.50 \%$ & 5 & 68.28 & na & $4.59 \%$ & $0.13 \%$ & $3.81 \%$ & $6.48 \%$ & $93.52 \%$ \\
\hline Italy & $\$$ & 959.06 & $-3.26 \%$ & $\$$ & 0.05 & na & $0.00 \%$ & $0.00 \%$ & $0.01 \%$ & $100.00 \%$ & $0.00 \%$ \\
\hline Japan & $\$$ & $4,757.80$ & $12.86 \%$ & $s$ & 129.00 & na & $8.67 \%$ & $0.08 \%$ & $2.71 \%$ & $19.50 \%$ & $80.50 \%$ \\
\hline Netherlands & $\$$ & 317.59 & $2.88 \%$ & 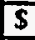 & 5.00 & na & $0.34 \%$ & $0.08 \%$ & $1.57 \%$ & $60.00 \%$ & $40.00 \%$ \\
\hline Norway & 5 & 102.44 & $-0.73 \%$ & $s$ & - & na & $0.00 \%$ & $0.00 \%$ & $0.00 \%$ & $100.00 \%$ & $0.00 \%$ \\
\hline Sweden & $\$$ & 173.59 & $-6.77 \%$ & $s$ & 116.00 & na & $7.80 \%$ & $2.12 \%$ & $66.82 \%$ & $0.00 \%$ & $100.00 \%$ \\
\hline Switzerland & $\$$ & 237.00 & $1.20 \%$ & 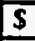 & 116.00 & na & $7.80 \%$ & $1.75 \%$ & $48.95 \%$ & $0.00 \%$ & $100.00 \%$ \\
\hline $\mathrm{U}, \mathrm{K}$. & $s$ & 927.01 & $-1.27 \%$ & $\$$ & 509.50 & na & $34.26 \%$ & $2.86 \%$ & \begin{tabular}{|l|}
$54.96 \%$ \\
\end{tabular} & $0.00 \%$ & $100.00 \%$ \\
\hline U.S.A. & $s$ & $6,579.47$ & $4.63 \%$ & $\$$ & 520.50 & na & $35.00 \%$ & $0.31 \%$ & $7.91 \%$ & $6.15 \%$ & $93.85 \%$ \\
\hline Total & $\$$ & $18,599.88$ & & $\$$ & 1487.31 & & & & & & \\
\hline & & & & & & & & & & & \\
\hline
\end{tabular}

1994 Funding Levels

(PPP's used)

\begin{tabular}{|c|c|c|c|c|c|c|c|c|c|c|}
\hline & Conversion Facto & & & dvanced Gas & 5 Turbine $\mathrm{R}$ & $\& D$ & & & & \\
\hline Country & $\overline{\mathrm{PPP}}$ & ER & & S\$ (million) & $\%$ change & $\%$ total & $\%$ total R\&D & $\%$ GDP & Public (\%) & Private (\%) \\
\hline Australia & 1.33 & 1.35 & $\$$ & - & na & $0.00 \%$ & $0.00 \%$ & $0.00 \%$ & $0.00 \%$ & $0.00 \%$ \\
\hline Belgium & 38.8 & 32.8 & s & - & na & $0.00 \%$ & $0.00 \%$ & $0.00 \%$ & $0.00 \%$ & $0.00 \%$ \\
\hline Canada & 1.25 & 1.38 & $\$$ & 0.09 & na & $0.01 \%$ & $0.00 \%$ & $0.00 \%$ & $0.01 \%$ & $0.00 \%$ \\
\hline Denmark & 9.3 & 6.26 & $\$$ & - & na & $0.00 \%$ & $0.00 \%$ & $0.00 \%$ & $0.00 \%$ & $0.00 \%$ \\
\hline European Union & 1 & 1 & $S$ & 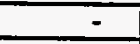 & na & $0.00 \%$ & $0.00 \%$ & $0.00 \%$ & $0.00 \%$ & $0.00 \%$ \\
\hline Finland & 6.46 & 5.24 & 5 & - & na & $0.00 \%$ & $0.00 \%$ & $0.00 \%$ & $0.00 \%$ & $0.00 \%$ \\
\hline \begin{tabular}{|l} 
France \\
\end{tabular} & 6.56 & 5.44 & $\mathbf{S}$ & 18.99 & na & $1.40 \%$ & $0.06 \%$ & $0.00 \%$ & $1.80 \%$ & $22.92 \%$ \\
\hline Germany & 2.13 & 1.6 & $\$$ & 51.29 & na & $3.77 \%$ & $0.13 \%$ & $0.00 \%$ & $3.81 \%$ & $6.48 \%$ \\
\hline Italy & 1523 & 1595 & $\overline{\$}$ & 0.05 & na & $0.00 \%$ & $0.00 \%$ & $0.00 \%$ & $0.01 \%$ & $100.00 \%$ \\
\hline Japan & 187 & 99.75 & $\$$ & 68.81 & na & $5.06 \%$ & $0.08 \%$ & $0.00 \%$ & $2.71 \%$ & $19.50 \%$ \\
\hline Netherlands & 2.17 & 1.79 & s & 4.12 & na & $0.30 \%$ & $0.08 \%$ & $0.00 \%$ & $1.57 \%$ & $60.00 \%$ \\
\hline Norway & 9.22 & 6.95 & $\mathbf{s}$ & - & na & $0.00 \%$ & $0.00 \%$ & $0.00 \%$ & $0.00 \%$ & $100.00 \%$ \\
\hline Sweden & 10.1 & 7.78 & $\mathbf{S}$ & 89.35 & na & $6.57 \%$ & $2.12 \%$ & $0.05 \%$ & $66.82 \%$ & $0.00 \%$ \\
\hline Switzerland & 2.22 & 1.54 & $\bar{s}$ & 80.47 & na & $5.92 \%$ & $1.75 \%$ & $0.03 \%$ & $48.95 \%$ & $0.00 \%$ \\
\hline U.K. & 0.64 & 0.66 & $\mathbf{s}$ & 525.42 & na & $38.66 \%$ & $2.86 \%$ & $0.06 \%$ & $54.96 \%$ & $0.00 \%$ \\
\hline U.S.A. & 1 & 1 & 5 & 520.50 & na & $38.30 \%$ & $0.31 \%$ & $0.01 \%$ & $7.91 \%$ & $6.15 \%$ \\
\hline & & & & & & & & & & \\
\hline Total & & & $\$$ & $1,359.10$ & & & & & & \\
\hline
\end{tabular}




\section{Appendix B. Fuel Cell Database}

\section{Australia}

\begin{tabular}{|l|l|l|l|l|}
\hline Project & $\begin{array}{l}\text { Funding } \\
\text { Source }\end{array}$ & Performer & Dates & $\begin{array}{l}\text { Funding Level } \\
\text { (US\$ } \\
\text { (million)* }\end{array}$ \\
\hline $\begin{array}{l}\text { SOFC Dev. } \\
\text { and Comm. } \\
\text { (Collins } \\
\text { Submarine) }\end{array}$ & $\begin{array}{l}\text { Federal } \\
\text { Government }\end{array}$ & Various & NA & 1 \\
\hline
\end{tabular}

* Estimated funding level; actual data not available.

\section{Belgium}

\begin{tabular}{|l|l|l|l|l|}
\hline Project & $\begin{array}{l}\text { Funding } \\
\text { Source }\end{array}$ & Performer & Dates & $\begin{array}{l}\text { Funding Level } \\
\text { US\$ (million) }\end{array}$ \\
\hline $\begin{array}{l}\text { PEFC } \\
\text { Electrode Dev. }\end{array}$ & VITO & VITO & Prior to 1993 & NA \\
\hline $\begin{array}{l}\text { AFC } \\
\text { Research } \\
\begin{array}{l}\text { Stack Dev. } \\
\text { Bus Demo. }\end{array}\end{array}$ & ELENCO & ELENCO & $\begin{array}{l}1976-1984 \\
1984-\text { present }\end{array}$ & $\begin{array}{l}18 \\
(1976-1984)\end{array}$ \\
\hline
\end{tabular}

\section{Canada}

\begin{tabular}{|l|l|l|l|l|}
\hline Project & $\begin{array}{l}\text { Funding } \\
\text { Source }\end{array}$ & Performer & Dates & $\begin{array}{l}\text { Funding Level } \\
\text { US\$ (million) }\end{array}$ \\
\hline $\begin{array}{l}\text { Alternative } \\
\text { Trans. Fuels (3 } \\
\text { projects) }\end{array}$ & $\begin{array}{l}\text {-Federal } \\
\text { Government. } \\
\text { (FERC) }\end{array}$ & Various & 1994 & .622 \\
\hline $\begin{array}{l}\text { PEFC } \\
\text { Development }\end{array}$ & $\begin{array}{l}\text { Ballard Power } \\
\text { Systems } \\
\text { (Daimler Benz) }\end{array}$ & $\begin{array}{l}\text { Ballard Power } \\
\text { Systems }\end{array}$ & $1994-1997$ & 125 \\
\hline
\end{tabular}


Canada. Continued.

\begin{tabular}{|l|l|l|l|l|}
\hline Project & $\begin{array}{l}\text { Funding } \\
\text { Source }\end{array}$ & Performer & Dates & $\begin{array}{l}\text { Funding Level } \\
\text { USS (million) }\end{array}$ \\
\hline & $\begin{array}{l}\text { Can. Elect. } \\
\text { Ass. }\end{array}$ & $\begin{array}{l}\text { BC Hydro } \\
\text { (Power Tech) }\end{array}$ & $1993-1995$ & .12 \\
$\begin{array}{l}200-\mathrm{kW} \\
\text { Demonstration }\end{array}$ & & Ontario Hydro & $1993-1995$ & .25 \\
$\begin{array}{l}\text { Westinghouse } \\
\text { SOFC }\end{array}$ & & Ontario Hydro & $1993-1995$ & .20 \\
\hline
\end{tabular}

\section{Denmark}

\begin{tabular}{|c|c|c|c|c|}
\hline Project & \begin{tabular}{|l|}
$\begin{array}{l}\text { Funding } \\
\text { Source }\end{array}$ \\
\end{tabular} & Performer & Dates & $\begin{array}{l}\text { Funding Level } \\
\text { USS (million) }\end{array}$ \\
\hline MCFC Asnaes & Elkraft & $\begin{array}{l}\text { Elkraft, Haldor } \\
\text { Topsoe, } \\
\text { Daimler Benz, } \\
\text { Ruhrgas }\end{array}$ & 1991-1995 & $2 / \mathrm{yr}$. \\
\hline $\begin{array}{l}\text { PAFC reformer } \\
\text { development }\end{array}$ & Haldor Topsoe & $\mathrm{NA}$ & $\overline{\mathrm{NA}}$ & $\overline{\mathrm{NA}}$ \\
\hline PAFC Jutland & $\overline{\text { ELSAM }}$ & $\begin{array}{l}\text { Elsam, } \\
\text { Naturgas Syd }\end{array}$ & 1994-1996* & $.050 / \mathrm{yr}$. \\
\hline$\overline{D M F C}$ & $\begin{array}{l}\text { Siemens, } \\
\text { Innovision, } \\
(50 \% \text { EC) }\end{array}$ & $\begin{array}{l}\text { Innovision, } \\
\text { Siemens }\end{array}$ & 1992 - Present & $\overline{\mathrm{NA}}$ \\
\hline PEFC & $\begin{array}{l}\text { Haldor Topsoe, } \\
\text { KFA Julich, } \\
\text { (50\% EC) }\end{array}$ & $\begin{array}{l}\text { Haldor Topsoe } \\
\text { KFA Julich }\end{array}$ & 1992 - Present & $\overline{\mathrm{NA}}$ \\
\hline SOFC & $\mathrm{EU}$ & $\begin{array}{l}\text { Riso Research } \\
\text { Center }\end{array}$ & 1994-1996* & 3.2 \\
\hline $\begin{array}{l}\text { SOFC stack } \\
\text { development }\end{array}$ & $\begin{array}{l}\text { British Gas } \\
\text { EU }\end{array}$ & $\begin{array}{l}\text { Riso Research } \\
\text { Center }\end{array}$ & 1993-1994 & .1 \\
\hline
\end{tabular}


Denmark. Continued.

\begin{tabular}{|l|l|l|l|l|}
\hline Project & $\begin{array}{l}\text { Funding } \\
\text { Source }\end{array}$ & Performer & Dates & $\begin{array}{l}\text { Funding Level } \\
\text { USS (million) }\end{array}$ \\
\hline $\begin{array}{l}\text { SOFC Jutland } \\
\text { Lab Scale }\end{array}$ & ELSAM & Same & $1991-1993$ & 7.6 \\
& Danish Energy & & & \\
SOFC Jutland & Agency (DEA) & & & \\
Scale-up & ELKRAFT & & $1993-1997$ & 14.4 \\
& Riso & & & $(4$, ELSAM) \\
& Innovision & & $(4$, DEA) \\
& Odense & & & \\
& University & & & \\
& Haldor Topsoe & & & \\
& Technical & & & \\
& University of & & & \\
& Denmark & & & \\
& & & & \\
\hline
\end{tabular}

* Projects were assumed to start in 1994.

\section{European Union}

\begin{tabular}{|c|c|c|c|c|}
\hline Project & $\begin{array}{l}\text { Funding } \\
\text { Source } \\
\end{array}$ & Performer & Dates & $\begin{array}{l}\text { Funding Level } \\
\text { US\$ (million) }\end{array}$ \\
\hline $\begin{array}{l}\text { Joule II } \\
\text { SOFC } \\
\text { MCFC }\end{array}$ & EU & \begin{tabular}{|l|} 
Various \\
British Gas, \\
TNO \\
(Netherlands) \\
\\
ECN, \\
Technical \\
University of \\
Delft \\
(Netherlands)
\end{tabular} & $1992-1995$ & $\begin{array}{l}15 \\
\mathrm{NA}\end{array}$ \\
\hline Joule II Top & $\overline{\mathrm{EU}}$ & Various & 1994-1997 & 8 \\
\hline $\begin{array}{l}\text { Brite Euram } \\
\text { PEFC }\end{array}$ & $\overline{E U}$ & $\begin{array}{l}\text { Various } \\
\text { AEA } \\
\text { Technology } \\
\text { (UK), EA } \\
\text { Technology } \\
\text { (UK), Power } \\
\text { Gen (UK) }\end{array}$ & $\begin{array}{l}1985-1997 \\
1994-\text { present }\end{array}$ & $\begin{array}{l}8 \\
1.5\end{array}$ \\
\hline
\end{tabular}


European Union. Continued.

\begin{tabular}{|l|l|l|l|l|}
\hline Project & $\begin{array}{l}\text { Funding } \\
\text { Source }\end{array}$ & Performer & Dates & $\begin{array}{l}\text { Funding Level } \\
\text { US\$ (million) }\end{array}$ \\
\hline Thermie & $\begin{array}{l}\text { European } \\
\text { Union }\end{array}$ & Various & $1986-1992$ & 7 \\
\hline EQHHPP & $\begin{array}{l}\text { Uuropean } \\
\text { Union }\end{array}$ & $\begin{array}{l}\text { EU Joint } \\
\text { Research } \\
\text { Centre }\end{array}$ & $1992-1997$ & 45 \\
\hline PEFC & EU & ECN & 1993 -present & 1 \\
\hline PEFC & EU & Tecnarrs & 1993 -present & NA \\
\hline PEFC & EU & KFA Julich & 1992 -present & NA \\
\hline PEFC & EU & Seimens & 1992 -present & 1.75 \\
\hline DMFC & EU & $\begin{array}{l}\text { Univeristy of } \\
\text { Bonn }\end{array}$ & NA & NA \\
\hline DMFC & EU & Siemens & NA & NA \\
\hline DMFC & EU & $\begin{array}{l}\text { University of } \\
\text { Cork (Ireland) }\end{array}$ & NA & NA \\
\hline
\end{tabular}

\section{Finland}

\begin{tabular}{|l|l|l|l|l|}
\hline Project & $\begin{array}{l}\text { Funding } \\
\text { Source }\end{array}$ & Performer & Dates & Funding Level \\
\hline $\begin{array}{l}\text { PAFC 200 KW } \\
\text { ONSI Demo }\end{array}$ & $\begin{array}{l}\text { IVO } \\
\text { primarily } \\
\text { EA Tech (UK) } \\
\text { and UK } \\
\text { regional } \\
\text { electric } \\
\text { companies }\end{array}$ & $\begin{array}{l}\text { IVO } \\
\text { EA Tech }\end{array}$ & $1993-1995$ & NA \\
\hline
\end{tabular}


France

\begin{tabular}{|c|c|c|c|c|}
\hline Project & \begin{tabular}{|l}
$\begin{array}{l}\text { Funding } \\
\text { Source }\end{array}$ \\
\end{tabular} & Performer & Dates & $\begin{array}{l}\text { Funding Level } \\
\text { USS (million) }\end{array}$ \\
\hline $\begin{array}{l}\text { SOFC stack } \\
\text { development }\end{array}$ & $\overline{E U}$ & Sapco & $\overline{\mathrm{NA}}$ & $\overline{\mathrm{NA}}$ \\
\hline $\begin{array}{l}\text { DMFC } \\
\text { dispersed } \\
\text { catalysts }\end{array}$ & $\begin{array}{l}\text {-Ademe } \\
\text { KFA Julich }\end{array}$ & $\begin{array}{l}\text { Univ. of } \\
\text { Poitiers }\end{array}$ & $5 / 5 / 93-5 / 5 / 96$ & .5 \\
\hline $\begin{array}{l}\text { DMFC } \\
\text { inorganic } \\
\text { electrolyte }\end{array}$ & $50 \%$ from EC & $\begin{array}{l}\text { Univ. of } \\
\text { Poitiers Univ. } \\
\text { of Bonn }\end{array}$ & Ongoing & $\overline{\mathrm{NA}}$ \\
\hline $\begin{array}{l}\text { AFC battery } \\
\text { supply to } \\
\text { Elenco }\end{array}$ & Elenco & SAFT & 1991-Present & $\overline{\mathrm{NA}}$ \\
\hline $\begin{array}{l}\mathrm{PEFC} \\
\text { manafactuing }\end{array}$ & Sorapec & Sorapec & NA & NA \\
\hline $\begin{array}{l}\text { Advamced } \\
\text { Technologies }\end{array}$ & Ademe & Various & $1992-1996$ & 3.7 \\
\hline $\begin{array}{l}\text { PEFC } \\
\text { vehicular }\end{array}$ & $\begin{array}{l}\text { CEA, CNRS, } \\
\text { SORAPEC } \\
\text { Ademe (50\%) }\end{array}$ & $\begin{array}{l}\text { GIE recherche } \\
\text { (cons. between } \\
\text { PSA/Renault) }\end{array}$ & $1992-1997$ & 1.8 \\
\hline CHP fuel cells & Gaz de France & Gaz de France & $\begin{array}{l}1994 \\
1995\end{array}$ & .1 \\
\hline EDF estimate & \begin{tabular}{|l} 
Elect. de \\
France
\end{tabular} & $\begin{array}{l}\text { Elect. de } \\
\text { France }\end{array}$ & 1993 & $\overline{5.4}$ \\
\hline $\begin{array}{l}\text { PEFC } \\
\text { Electrolyte } \\
\text { Development }\end{array}$ & $\begin{array}{l}\text { EC } \\
\text { French Govt. }\end{array}$ & $\overline{\mathrm{CEA}}$ & & .5 \\
\hline
\end{tabular}

\section{Germany}




\begin{tabular}{|c|c|c|c|c|}
\hline \begin{tabular}{|l|} 
Project \\
\end{tabular} & \begin{tabular}{|l} 
Funding \\
Source
\end{tabular} & Performer & Dates & $\begin{array}{l}\text { Funding Level } \\
\text { US\$ (million) }\end{array}$ \\
\hline $\begin{array}{l}\text { MCFC Pilot } \\
\text { Plant }\end{array}$ & $\begin{array}{l}\text { Federal } \\
\text { Government } \\
\\
\text { Deutsche } \\
\text { Aerospace }\end{array}$ & $\begin{array}{l}\text { Deutsche } \\
\text { Aerospace } \\
\text { Energy } \\
\text { Research Co. } \\
\text { (US) } \\
\end{array}$ & $1990-1994$ & $\begin{array}{l}14 \text { (50\% govt.; } \\
50 \% \text { private) }\end{array}$ \\
\hline $\begin{array}{l}\text { MCFC syst. } \\
\text { dev. and demo }\end{array}$ & \begin{tabular}{|l|} 
MTU \\
Ruhrgas \\
Haldor Topsoe \\
(Denmark) \\
Elkraft \\
(Denmark)
\end{tabular} & $\begin{array}{l}\text { MTU } \\
\text { Ruhrgas } \\
\text { Haldor Topsoe } \\
\text { Elkraft }\end{array}$ & $1991-1995$ & 20 \\
\hline $\begin{array}{l}\text { PAFC Demo } \\
\text { Nat.Gas. }\end{array}$ & Ruhrgas & $\begin{array}{l}\text { Ruhrgas (ONSI } \\
\text { stack) }\end{array}$ & Since 1993 & $\overline{\mathrm{NA}}$ \\
\hline $\begin{array}{l}\text { PAFC Demo } \\
\text { Nat. Gas }\end{array}$ & Thyssengas & $\begin{array}{l}\text { Thyssengas } \\
\text { (ONSI stack) }\end{array}$ & $\mathrm{NA}$ & $\overline{\mathrm{NA}}$ \\
\hline $\begin{array}{l}\text { PAFC Demo } \\
\text { Nat. Gas }\end{array}$ & HEAG & $\begin{array}{l}\text { HEAG (ONSI } \\
\text { stack) }\end{array}$ & NA & $\overline{\mathrm{NA}}$ \\
\hline $\begin{array}{l}\text { PAFC Demo } \\
\text { Hydrogen }\end{array}$ & \begin{tabular}{|l|} 
KTI/Solar- \\
Wasserstoff \\
Bayern \\
\end{tabular} & $\begin{array}{l}\text { KTI/Solar } \\
\text { (ONSI stack) }\end{array}$ & $\mathrm{NA}$ & $\mathrm{NA}$ \\
\hline $\begin{array}{l}\text { PEFC stack for } \\
\text { transport. }\end{array}$ & \begin{tabular}{|l|} 
Siemens \\
EC (50\%)
\end{tabular} & $\begin{array}{l}\text { Siemens } \\
\text { AEA Tech. } \\
\text { CEA } \\
\text { PSI }\end{array}$ & 1992-present & 3.5 \\
\hline $\begin{array}{l}\text { PEFC stack } \\
\text { evaluation }\end{array}$ & Daimler Benz & $\begin{array}{l}\text { Daimler Benz } \\
\text { Ballard (Can) }\end{array}$ & 1990-present & 60 \\
\hline $\begin{array}{l}\text { PEFC stack } \\
\text { dev. }\end{array}$ & $\begin{array}{l}\text { Daimler Benz } \\
(70 \%) \\
\text { Ballard (Can) } \\
(30 \%)\end{array}$ & $\begin{array}{l}\text { Daimler Benz } \\
\text { Ballard (Can.) }\end{array}$ & 1993-1997 & 35 \\
\hline $\begin{array}{l}\text { PEFC } \\
\text { methanol } \\
\text { reformer dev. }\end{array}$ & $\begin{array}{l}\text { KFA Julich } \\
\text { Haldor Topsoe } \\
\text { (Denamrk) } \\
\text { EC }(50 \%)\end{array}$ & $\begin{array}{l}\text { KFA Julich } \\
\text { Haldor Topsoe }\end{array}$ & 1992 - present & $\overline{\mathrm{NA}}$ \\
\hline
\end{tabular}


Germany. Continued.

\begin{tabular}{|c|c|c|c|c|}
\hline Project & \begin{tabular}{|l|} 
Funding \\
Source
\end{tabular} & $\overline{\text { Performer }}$ & Dates & $\begin{array}{l}\text { Funding Level } \\
\text { USS (million) }\end{array}$ \\
\hline $\begin{array}{l}\text { PEFC } \\
\text { (Hydrogen } \\
\text { econ. } \\
\text { activities) }\end{array}$ & \begin{tabular}{|l} 
BMW \\
SWB \\
DASA \\
Linde
\end{tabular} & $\begin{array}{l}\text { BMW } \\
\text { SWB } \\
\text { DASA } \\
\text { Linde }\end{array}$ & $1987-1996$ & 87 \\
\hline $\begin{array}{l}\text { DMFC stack } \\
\text { dev. }\end{array}$ & \begin{tabular}{|l} 
Siemens \\
EC (50\%)
\end{tabular} & Siemens & 1992 - Present & $\overline{\mathrm{NA}}$ \\
\hline $\begin{array}{l}\text { DMFC inorg. } \\
\text { electr. dev. }\end{array}$ & $\mathrm{EC}(>50 \%)$ & $\begin{array}{l}\text { Univ. of Bonn } \\
\text { Univ. of } \\
\text { Poitiers }\end{array}$ & & $\overline{\mathrm{NA}}$ \\
\hline AFC stack dev. & Siemens & Siemens & pre-1988 & $\overline{\mathrm{NA}}$ \\
\hline AFFFC dev. & Hoescht & Hoescht & $\overline{\mathrm{NA}}$ & $\overline{\mathrm{NA}}$ \\
\hline $\begin{array}{l}\text { Ceramic for } \\
\text { Fuel Cells }\end{array}$ & Government & $\begin{array}{l}\text { Fraunhofer } \\
\text { Gesellschaft } \\
\text { (Government } \\
\text { res. } \\
\text { organization) }\end{array}$ & 1992-1993 & .6 \\
\hline $\begin{array}{l}\text { SOFC dev. and } \\
\text { apllication }\end{array}$ & \begin{tabular}{|l|} 
Seimens \\
Federal \\
Government
\end{tabular} & Siemens & $1991-1993$ & 8 \\
\hline $\begin{array}{l}\text { SOFC } \\
\text { prototype }\end{array}$ & $\begin{array}{l}\text { Dornier } \\
\text { Federal } \\
\text { Government }\end{array}$ & Dornier & 1991-1993 & 3 million US\$ \\
\hline
\end{tabular}


Italy

\begin{tabular}{|c|c|c|c|c|}
\hline Project & Funder & Performer & Dates & $\begin{array}{l}\text { Funding Level } \\
\text { (US\$ million) }\end{array}$ \\
\hline $\mathrm{MCFC}$ & $\begin{array}{l}\text { Italian } \\
\text { Government } \\
\text { (ENEA) }\end{array}$ & $\overline{\text { ENEA }}$ & 1994-1996 & 8.1 \\
\hline$\overline{\mathrm{MCFC}}$ & $\begin{array}{l}\text { Private } \\
\text { Industry } \\
\text { (Ansaldo, } \\
\text { CISE) }\end{array}$ & NA & 1994-1996 & 8.1 \\
\hline SOFC, PAFC & $\begin{array}{l}\text { Government } \\
\text { (ENEA) }\end{array}$ & ENEA & 1994-1996 & .9 \\
\hline SOFC,PAFC & Private & $\mathrm{NA}$ & $1994-1996$ & .9 \\
\hline PEFC & $\begin{array}{l}\text { Govt. (Min. of } \\
\text { Industry) }\end{array}$ & NA & $1994-1996$ & 19 \\
\hline$\overline{P E F C}$ & $\begin{array}{l}\text { DeNora } \\
\text { Fiat/Avio } \\
\text { Ansaldo } \\
\text { Tecnars }\end{array}$ & $\overline{N A}$ & 1994-1996 & $\begin{array}{l}\text { /yr. } \\
30 \\
\text { NA } \\
\text { NA } \\
\end{array}$ \\
\hline$\overline{\mathrm{AFC}}$ (Elenco) & Ansaldo & Ansaldo & 1991-present & $\overline{\mathrm{NA}}$ \\
\hline PAFC & Eniricerche & Eniricerche & NA & $\mathrm{NA}$ \\
\hline$\overline{\mathrm{PAFC}}$ & ACOSER & ACOSER & $\overline{\mathrm{NA}}$ & $\overline{\mathrm{NA}}$ \\
\hline PAFC & CLC & CLC & $\mathrm{NA}$ & $\mathrm{NA}$ \\
\hline PAFC & $\overline{\text { ENEA }}$ & $\mathrm{NA}$ & $1990-1994$ & 16 \\
\hline
\end{tabular}




\section{Japan}

\begin{tabular}{|c|c|c|c|c|}
\hline Project & \begin{tabular}{|l|} 
Funding \\
Source
\end{tabular} & Performer & Dates & \begin{tabular}{|l|} 
Funding Level \\
USS (million) \\
\end{tabular} \\
\hline Various & $\begin{array}{l}\text { Federal } \\
\text { Government }\end{array}$ & Various & 1994 & 68 \\
\hline Various & $\begin{array}{l}\text { Tokyo Elect. } \\
\text { Power Co. }\end{array}$ & Various & 1994 & 37.9 \\
\hline Various & $\begin{array}{l}\text { Kansai Elect. } \\
\text { Power Co. }\end{array}$ & Various & 1994 & 19 \\
\hline Various & $\begin{array}{l}\text { Chubu Elect. } \\
\text { Power Co. }\end{array}$ & Various & 1994 & $15.7^{*}$ \\
\hline Various & $\begin{array}{l}\text { Tohoku Elect. } \\
\text { Power Co. }\end{array}$ & Various & 1994 & $0.7^{*}$ \\
\hline $\begin{array}{l}\text { PAFC } \\
\text { Research } \\
\text { Association }\end{array}$ & Members & Various & 1991-1996 & 120 \\
\hline Various & Tokyo Gas & Various & 1994 & $10.9^{*}$ \\
\hline Small PAFC & Sanyo & Sanyo & $1993-1994$ & $\overline{\mathrm{NA}}$ \\
\hline Various & $\overline{\mathrm{IHI}}$ & IHI & 1994 & $15.7^{*}$ \\
\hline Various & Fuji & Fuji & 1994 & $15.7^{*}$ \\
\hline Various & Hitachi & Hitachi & 1994 & $15.7^{*}$ \\
\hline $\begin{array}{l}\text { Operation and } \\
\text { testing of } \\
\text { PAFC }\end{array}$ & \begin{tabular}{|l} 
Mitsubishi \\
\end{tabular} & Various & 1993 & $3.6^{*}$ \\
\hline
\end{tabular}

* Estimated funding levels for all fuel cell R\&D activities. 
Netherlands

\begin{tabular}{|l|l|l|l|l|}
\hline Project & $\begin{array}{l}\text { Funding } \\
\text { Souce }\end{array}$ & Performer & Dates & $\begin{array}{l}\text { Funding Level } \\
\text { US\$ (million) }\end{array}$ \\
\hline Various & $\begin{array}{l}\text { Federal } \\
\text { Government }\end{array}$ & Various & 1991 -Present & 11.2 \\
\hline Various & $\begin{array}{l}\text { Private } \\
\text { Industry }\end{array}$ & Various & 1991 -Present & 5 \\
\hline
\end{tabular}

Norway

\begin{tabular}{|l|l|l|l|l|}
\hline Project & $\begin{array}{l}\text { Funding } \\
\text { Source }\end{array}$ & Performer & Dates & $\begin{array}{l}\text { Funding Level } \\
\text { US\$ (million) }\end{array}$ \\
\hline SOFC & Statoil & Statoil & $1990-1995$ & 15 \\
\hline $\begin{array}{l}\text { Norcell } \\
\text { (SOFC) }\end{array}$ & $\begin{array}{l}\text { Federal } \\
\text { Government } \\
\text { (Research } \\
\text { Council of } \\
\text { Norway) }\end{array}$ & Various & 1994 & .86 \\
\hline
\end{tabular}

Sweden

\begin{tabular}{|l|l|l|l|l|}
\hline Project & Funder & Performer & Dates & $\begin{array}{l}\text { Funding Level } \\
\text { USS (million) }\end{array}$ \\
\hline MCFC & $\begin{array}{l}\text { NUTEK } \\
\text { (Swedish } \\
\text { National Board } \\
\text { for Industrial } \\
\text { and } \\
\text { Technology } \\
\text { Development) }\end{array}$ & $\begin{array}{l}\text { Royal Institute } \\
\text { of Technology }\end{array}$ & NA & NA \\
\hline MCFC & Vattenfall & Vattenfall & NA & NA \\
\hline MCFC & Sydkraft & Sydkraft & NA & NA \\
\hline PAFC (Demo) & Vattnefall & Vattenfall & NA & NA \\
\hline PAFC (Demo) & Sydkraft & Sydkraft & NA & NA \\
\hline
\end{tabular}


Switzerland

\begin{tabular}{|l|l|l|l|l|}
\hline Project & $\begin{array}{l}\text { Funding } \\
\text { Source }\end{array}$ & Performer & Dates & $\begin{array}{l}\text { Funding Level } \\
\text { US\$ (million) }\end{array}$ \\
\hline $\begin{array}{l}\text { PAFC } \\
\text { Demonstration }\end{array}$ & SIG & SIG & $1992-1997$ & NA \\
\hline $\begin{array}{l}\text { SOFC } \\
\text { (HEXIS) }\end{array}$ & $\begin{array}{l}\text { Sulzer, Swiss } \\
\text { Department of } \\
\text { Energy }\end{array}$ & Sulzer & NA & $1(60 \%$ govt.) \\
\hline SOFC & $\begin{array}{l}\text { Swiss Federal } \\
\text { Government }\end{array}$ & $\begin{array}{l}\text { Lausanne } \\
\text { Univ. } \\
\text { Zurich Univ. }\end{array}$ & NA & NA \\
\hline PEFC & $\begin{array}{l}\text { European } \\
\text { Union }\end{array}$ & $\begin{array}{l}\text { Paul Scherrer } \\
\text { Institute }\end{array}$ & NA & NA \\
\hline
\end{tabular}

United Kingdom

\begin{tabular}{|l|l|l|l|l|}
\hline Project & $\begin{array}{l}\text { Funding } \\
\text { Source }\end{array}$ & Performer & Dates & $\begin{array}{l}\text { Funding Level } \\
\text { US\$ (million) }\end{array}$ \\
\hline $\begin{array}{l}\text { SOFC plate } \\
\text { cells }\end{array}$ & $\begin{array}{l}\text { British Gas, } \\
\text { EC-JOULE II } \\
(50 \%), \\
\text { Government } \\
(5 \%)\end{array}$ & $\begin{array}{l}\text { Brit. Gas, } \\
\text { Tioxide, BNFL }\end{array}$ & $1993-1994$ & 1.4 \\
\hline IP-SOFC & $\begin{array}{l}\text { Rolls Royce } \\
\text { Government } \\
(60 \%)\end{array}$ & $\begin{array}{l}\text { Rolls Royce } \\
\text { Birmingham } \\
\text { University } \\
\text { Keele } \\
\text { University } \\
\text { CERAM } \\
\text { Research }\end{array}$ & $1993-1994$ & 500,000 US\$ \\
\hline $\begin{array}{l}\text { SOFC stack } \\
\text { dev. }\end{array}$ & $\begin{array}{l}\text { EU (50\%), } \\
\text { CPSL, Sapco, } \\
\text { Viking }\end{array}$ & $\begin{array}{l}\text { Keele } \\
\text { University } \\
\text { Sapco, Viking, } \\
\text { CPSL }\end{array}$ & $1994-1997$ & 2 \\
\hline SOFC & NA & $\begin{array}{l}\text { Keele } \\
\text { University }\end{array}$ & NA & NA \\
\hline
\end{tabular}


United Kingdom. Continued.

\begin{tabular}{|c|c|c|c|c|}
\hline Project & $\begin{array}{l}\text { Funding } \\
\text { Source } \\
\end{array}$ & Performer & Dates & \begin{tabular}{|l|} 
Funding Level \\
US\$ (million) \\
\end{tabular} \\
\hline $\begin{array}{l}\text { SOFC low } \\
\text { temp. }\end{array}$ & EU, Seimens & $\begin{array}{l}\text { Imperial } \\
\text { College }\end{array}$ & $\mathrm{NA}$ & NA \\
\hline $\begin{array}{l}\text { SOFC low } \\
\text { temp. }\end{array}$ & Govt. & $\begin{array}{l}\text { Imperial } \\
\text { College }\end{array}$ & 1993-1996 & .7 \\
\hline $\begin{array}{l}\text { SOFC balance } \\
\text { of plant }\end{array}$ & $\begin{array}{l}\text { British Gas, } \\
\text { Govt. (25\%) } \\
\text { EU (50\%) }\end{array}$ & $\begin{array}{l}\text { Briish. Gas } \\
\text { Eniricerche }\end{array}$ & 1994-1996 & 1.5 \\
\hline $\begin{array}{l}\text { SOFC sealing } \\
\text { and bonding }\end{array}$ & $\overline{E U}$ & $\begin{array}{l}\text { GEC Alsthom } \\
\text { Cookson }\end{array}$ & $\overline{\mathrm{NA}}$ & $\mathrm{NA}$ \\
\hline $\begin{array}{l}\text { SOFC internal } \\
\text { reforming }\end{array}$ & British Gas & British Gas & $\overline{\mathrm{NA}}$ & $\mathrm{NA}$ \\
\hline $\begin{array}{l}\text { SOFC } \\
\text { microwave } \\
\text { assisted firing }\end{array}$ & $\begin{array}{l}\text { EA } \\
\text { Technology }\end{array}$ & $\begin{array}{l}\text { EA } \\
\text { Technology }\end{array}$ & $\overline{\mathrm{NA}}$ & $\overline{\mathrm{NA}}$ \\
\hline MCFC stack & $\begin{array}{l}\text { British Gas } \\
\text { EU (50\%) }\end{array}$ & $\begin{array}{l}\text { British Gas } \\
\text { ECN } \\
\text { (Netherlands) } \\
\text { CNR-TAE } \\
\text { (Italy) }\end{array}$ & 1993-1995 & 3 \\
\hline $\begin{array}{l}\text { PEFC system } \\
\text { demo }\end{array}$ & $\begin{array}{l}\text { VSEL } \\
\text { CJB } \\
\text { Developments }\end{array}$ & $\begin{array}{l}\text { VSEL } \\
\text { CJB } \\
\text { Developments }\end{array}$ & prior to 1990 & 1 \\
\hline PEFC reformer & $\begin{array}{l}\text { CJB, ECN } \\
\text { (Netherlands) }\end{array}$ & CJB, ECN & 1994-1996 & .25 \\
\hline \begin{tabular}{|l|} 
PEFC vehicle \\
demonstration
\end{tabular} & $\begin{array}{l}\text { VSEL, CJB, } \\
\text { Rover, and } \\
\text { Lucas } \\
\end{array}$ & Same & $1993-1997$ & $\overline{\mathrm{NA}}$ \\
\hline PEFC dev. & $\begin{array}{l}\text { Johnson } \\
\text { Matthey, } \\
\text { Government } \\
(30 \%)\end{array}$ & $\begin{array}{l}\text { Johnson } \\
\text { Matthey }\end{array}$ & $1993-1994$ & .75 \\
\hline
\end{tabular}


United Kingdom. Continued.

\begin{tabular}{|c|c|c|c|c|}
\hline Project & \begin{tabular}{|l|}
$\begin{array}{l}\text { Funding } \\
\text { Source }\end{array}$ \\
\end{tabular} & Performer & Dates & $\begin{array}{l}\text { Funding Level } \\
\text { US\$ (million) }\end{array}$ \\
\hline PEFC & \begin{tabular}{|l|} 
Johnson \\
Matthey
\end{tabular} & $\begin{array}{l}\text { Johnson } \\
\text { Matthey }\end{array}$ & $\mathrm{NA}$ & $\overline{\mathrm{NA}}$ \\
\hline PEFC (Ballard) & \begin{tabular}{|l|} 
Johnson \\
Matthey
\end{tabular} & \begin{tabular}{|l|} 
Johnson \\
Matthey
\end{tabular} & $\overline{\mathrm{NA}}$ & $\overline{\mathrm{NA}}$ \\
\hline PEFC (IEA) & \begin{tabular}{|l} 
Johnson \\
Matthey
\end{tabular} & $\begin{array}{l}\text { Johnson } \\
\text { Matthey }\end{array}$ & $\overline{\mathrm{NA}}$ & $\overline{\mathrm{NA}}$ \\
\hline $\begin{array}{l}\text { PEFC (Hot } \\
\text { Spot) }\end{array}$ & $\begin{array}{l}\text { Johnson } \\
\text { Matthey }\end{array}$ & $\begin{array}{l}\text { Johnson } \\
\text { Matthey }\end{array}$ & $\overline{\mathrm{NA}}$ & NA \\
\hline PEFC clean up & $\begin{array}{l}\text { British Gas } \\
\text { Government } \\
(50 \%)\end{array}$ & British Gas & 1992-1994 & .3 \\
\hline $\begin{array}{l}\text { PEFC ceramic } \\
\text { membrane }\end{array}$ & British Gas & British Gas & $\overline{\mathrm{NA}}$ & NA \\
\hline $\begin{array}{l}\text { PEFC natural } \\
\text { gas reformer }\end{array}$ & $\begin{array}{l}\text { British Gas } \\
\text { Government } \\
(50 \%)\end{array}$ & British Gas & \begin{tabular}{|c|}
$1992-1994$ \\
\end{tabular} & .4 \\
\hline $\begin{array}{l}\text { PEFC } \\
\text { autothermal } \\
\text { reformer }\end{array}$ & $\begin{array}{l}\text { Rolls Royce, } \\
\text { Government } \\
(30 \%)\end{array}$ & Rolls Royce & \begin{tabular}{|c|}
$1992-1994$ \\
\end{tabular} & .4 \\
\hline $\begin{array}{l}\text { PEFC EU } \\
\text { BRITE } \\
\text { EURAM }\end{array}$ & \begin{tabular}{|l|} 
AEA \\
Technology \\
EA \\
Technology \\
PowerGen \\
Government \\
$(50 \%)$ \\
EU
\end{tabular} & \begin{tabular}{|l|} 
AEA \\
Technology \\
EA \\
Technology \\
PowerGen
\end{tabular} & 1994 & 3 \\
\hline $\begin{array}{l}\text { PEFC } \\
\text { (Siemens) }\end{array}$ & Seimens & $\begin{array}{l}\text { Loughborough } \\
\text { University }\end{array}$ & $\overline{\mathrm{NA}}$ & $\overline{\mathrm{NA}}$ \\
\hline
\end{tabular}


United Kingdom. Continued.

\begin{tabular}{|l|l|l|l|l|}
\hline $\begin{array}{l}\text { PEFC stack } \\
\text { development }\end{array}$ & Government & $\begin{array}{l}\text { Loughborough } \\
\text { University }\end{array}$ & $1992-1994$ & .3 \\
\hline
\end{tabular}

\section{United States}

\begin{tabular}{|c|c|c|c|c|}
\hline Project & $\begin{array}{l}\text { Funding } \\
\text { Source }\end{array}$ & Performer & $\overline{\text { Dates }}$ & $\begin{array}{l}\text { Funding Level } \\
\text { US\$ (million) }\end{array}$ \\
\hline Various & $\begin{array}{l}\text { Department of } \\
\text { Energy }\end{array}$ & Various & $\begin{array}{l}1994 \\
1993\end{array}$ & $\begin{array}{l}51.8 \\
51.1\end{array}$ \\
\hline Various & NASA & Various & 1994 & $\overline{\mathrm{NA}}$ \\
\hline Various & Defense Dept. & Various & 1994 & 35.4 \\
\hline Various & $\begin{array}{l}\text { Fuel Cell } \\
\text { Commercializat } \\
\text { ion Group }\end{array}$ & $\begin{array}{l}\text { Energy } \\
\text { Research } \\
\text { Corporation }\end{array}$ & $1994-1998$ & 69 \\
\hline Various & $\begin{array}{l}\text { Energy } \\
\text { Research } \\
\text { Corporation }\end{array}$ & $\begin{array}{l}\text { Energy } \\
\text { Research } \\
\text { Corporation }\end{array}$ & $\begin{array}{l}1993 \\
1992\end{array}$ & $\begin{array}{l}1.2 \\
1.5\end{array}$ \\
\hline Various & $\begin{array}{l}\text { GRI } \\
\text { (Cooperative } \\
\text { Member } \\
\text { Support) }\end{array}$ & Various & $\begin{array}{l}1996 \\
1995\end{array}$ & $\begin{array}{l}4.5 \\
(16.1) \\
3.85 \\
(12.1)\end{array}$ \\
\hline Various & $\begin{array}{l}\text { EPRI } \\
\text { (Cooperative } \\
\text { Member } \\
\text { support) } \\
\end{array}$ & Various & 1994 & $\begin{array}{l}6 \\
(6)\end{array}$ \\
\hline Various & MC Power & MC Power & $1995-1999$ & 30 \\
\hline Various & Westinghouse & Westinghouse & $\begin{array}{l}1993 \\
1992\end{array}$ & $\begin{array}{l}9.8^{*} \\
9.7^{*}\end{array}$ \\
\hline $\begin{array}{l}\text { Thin Layers } \\
\text { SOFC }\end{array}$ & Allied Signal & Allied Signal & 1993 & DOE-funded \\
\hline
\end{tabular}




\section{United States}

\begin{tabular}{|l|l|l|l|l|}
\hline Project & $\begin{array}{l}\text { Funding } \\
\text { Source }\end{array}$ & Performer & Dates & $\begin{array}{l}\text { Funding Level } \\
\text { US\$ (million) }\end{array}$ \\
\hline $\begin{array}{l}\text { Green Car } \\
\text { Project }\end{array}$ & EP Fuel Cells & EP Fuel Cells & $1991-1993$ & 3.4 \\
\hline Various & H Power & H Power & NA & NA \\
\hline Various & $\begin{array}{l}\text { International } \\
\text { Fuel Cells }\end{array}$ & $\begin{array}{l}\text { International } \\
\text { Fuel Cells }\end{array}$ & 1993 & $3.5^{*}$ \\
\hline
\end{tabular}

* Estimated levels of expenditures. 


\section{Appendix C. Advanced Gas Turbine Database}

Australia

\begin{tabular}{|l|l|l|l|l|}
\hline Project & $\begin{array}{l}\text { Funding } \\
\text { Source }\end{array}$ & Performer & Dates & Funding Level \\
\hline None & $\begin{array}{l}\text { Federal } \\
\text { Government }\end{array}$ & NA & NA & None \\
\hline
\end{tabular}

\section{Belgium}

\begin{tabular}{|l|l|l|l|l|}
\hline Project & $\begin{array}{l}\text { Funding } \\
\text { Source }\end{array}$ & Performer & Dates & Funding Level \\
\hline None & $\begin{array}{l}\text { Federal } \\
\text { Government }\end{array}$ & NA & NA & None \\
\hline
\end{tabular}

\section{Canada}

\begin{tabular}{|l|l|l|l|l|}
\hline Project & $\begin{array}{l}\text { Funding } \\
\text { Source }\end{array}$ & Performer & Dates & Funding Level \\
\hline None & $\begin{array}{l}\text { Federal } \\
\text { Government }\end{array}$ & NA & NA & NA \\
\hline Various & $\begin{array}{l}\text { Canadian } \\
\text { Electrical } \\
\text { Association }\end{array}$ & EPRI/PGE & $1993-1996$ & $\$ 325,000$ \\
\hline
\end{tabular}

Denmark

\begin{tabular}{|l|l|l|l|l|}
\hline Project & $\begin{array}{l}\text { Funding } \\
\text { Source }\end{array}$ & Performer & Dates & Funding Level \\
\hline None & $\begin{array}{l}\text { Federal } \\
\text { Government }\end{array}$ & NA & NA & None \\
\hline
\end{tabular}

European Union

Not Available at the time of this writing. 
Finland

\begin{tabular}{|l|l|l|l|l|}
\hline Project & $\begin{array}{l}\text { Funding } \\
\text { Source }\end{array}$ & Performer & Dates & Funding Level \\
\hline None & $\begin{array}{l}\text { Federal } \\
\text { Government }\end{array}$ & NA & NA & None \\
\hline
\end{tabular}

France

\begin{tabular}{|l|l|l|l|l|}
\hline Project & $\begin{array}{l}\text { Funding } \\
\text { Source }\end{array}$ & Performer & Dates & $\begin{array}{l}\text { Funding Level } \\
\text { US\$ (million) }\end{array}$ \\
\hline None & Government & NA & NA & None \\
\hline EDF Estimate & $\begin{array}{l}\text { Electricite de } \\
\text { France }\end{array}$ & Various & 1993 & 5.4 \\
\hline Various & $\begin{array}{l}\text { GEC Alsthom; } \\
\text { European Gas } \\
\text { Turbines }\end{array}$ & Various & 1993 & 17.5 \\
\hline
\end{tabular}

\section{Germany}

\begin{tabular}{|l|l|l|l|l|}
\hline Project & $\begin{array}{l}\text { Funding } \\
\text { Source }\end{array}$ & Performer & Dates & $\begin{array}{l}\text { Funding Level } \\
\text { US\$ (million) }\end{array}$ \\
\hline $\begin{array}{l}\text { Total Gas } \\
\text { Turbines }\end{array}$ & $\begin{array}{l}\text { Government } \\
\text { (Min. for Ed., } \\
\text { Sci., Res. and } \\
\text { Tech) }\end{array}$ & Various & 1992 & 1993 \\
& & 1994 & 1.0 \\
& & 1.2 & \\
\hline $\begin{array}{l}\text { Seimens } \\
\text { Estimate }\end{array}$ & Seimens & Seimens & 1993 & 60 \\
& & 1992 & 60.7 \\
\hline $\begin{array}{l}\text { German } \\
\text { Aerospace Res. } \\
\text { Establishment }\end{array}$ & $\begin{array}{l}\text { Government } \\
\text { private (50\%) }\end{array}$ & Various & $1986-1995$ & 62.7 \\
\hline $\begin{array}{l}\text { All further projects are in cooperation with the German Aerospace Research } \\
\text { Establishment project and their funding is included in the 62.7 million US\$ shown } \\
\text { above. All funding levels for futher projects are in German Marks. }\end{array}$ \\
\hline
\end{tabular}


Germany. Continued.

\begin{tabular}{|c|c|c|c|c|}
\hline Project & $\begin{array}{l}\text { Funding } \\
\text { Source }\end{array}$ & Performer & Dates & $\begin{array}{l}\text { Funding Level } \\
\text { USS (million) }\end{array}$ \\
\hline & $\begin{array}{l}\text { Deutsche } \\
\text { Forschungsanst } \\
\text { alt fur Luft und } \\
\text { Raumfahrt }\end{array}$ & & $\begin{array}{l}1991-1994 \\
1991-1995\end{array}$ & \begin{tabular}{|l|}
.52 \\
5.47
\end{tabular} \\
\hline & $\begin{array}{l}\text { BMW Rolls } \\
\text { Royce }\end{array}$ & & $\begin{array}{l}1989-1994 \\
1989-1993 \\
1992-1996\end{array}$ & $\begin{array}{l}2.34 \\
3.33 \\
1.11\end{array}$ \\
\hline & $\begin{array}{l}\text { Motoren und } \\
\text { Turbinenunion } \\
\text { (MTU) }\end{array}$ & & $\begin{array}{l}1989-1992 \\
1990-1994 \\
1992-1996\end{array}$ & $\begin{array}{l}3.78 \\
3.12 \\
.58\end{array}$ \\
\hline & Siemens & & $\begin{array}{l}1986-1993 \\
1989-1993 \\
1990-1993\end{array}$ & $\begin{array}{l}1.83 \\
3.07\end{array}$ \\
\hline & Daimler-Benz & & $1990-1994$ & .32 \\
\hline & $\begin{array}{l}\text { Energiewerke } \\
\text { Schwarze } \\
\text { Pumpe } \\
\end{array}$ & & $1991-1993$ & .07 \\
\hline & $\begin{array}{l}\text { Fichtner Dev. } \\
\text { Engineering }\end{array}$ & & 1992 & 8.72 \\
\hline & $\begin{array}{l}\text { Bundesanstalt } \\
\text { fur } \\
\text { Materilprufung }\end{array}$ & & $1992-1993$ & 1.53 \\
\hline & Universities & & $1986-1995$ & 1.18 \\
\hline & Aachen Tech & & $1986-1995$ & 1.07 \\
\hline & $\begin{array}{l}\text { Darmstadt } \\
\text { Tech }\end{array}$ & & 1986-1994 & 2.33 \\
\hline & Munich Tech & & $1986-1994$ & .57 \\
\hline & Bochum & & $1989-1994$ & .30 \\
\hline
\end{tabular}


Germany. Continued.

\begin{tabular}{|l|l|l|l|l|}
\hline Project & $\begin{array}{l}\text { Funding } \\
\text { Source }\end{array}$ & Performer & Dates & $\begin{array}{l}\text { Funding Level } \\
\text { USS (million) }\end{array}$ \\
\hline & Karlsruhe & & $1989-1994$ & .26 \\
\hline & Zittau/Gorlitz & & $1992-1995$ & .68 \\
\hline & Munich Army & & $1989-1993$ & 1.35 \\
\hline & Hannover & & $1990-1994$ & .44 \\
\hline & $\begin{array}{l}\text { Stuttgart } \\
\text { Tech }\end{array}$ & & $1989-1994$ & 1.02 \\
\hline & $\begin{array}{l}\text { Clausthal Tech. } \\
\text { Fraunschweig } \\
\text { Fuel Institute) }\end{array}$ & & $1989-1993$ & .47 \\
\hline & $\begin{array}{l}\text { Dresden Tech } \\
\text { Tech. }\end{array}$ & & $1989-1992$ & .82 \\
\hline & $\begin{array}{l}\text { Essen } \\
\text { Magdeburg }\end{array}$ & $1992-1996$ & .67 \\
\hline
\end{tabular}

\section{Italy}

\begin{tabular}{|l|l|l|l|l|}
\hline Project & Funder & Performer & Dates & $\begin{array}{l}\text { Funding Level } \\
\text { USS (million) }\end{array}$ \\
\hline Aeroderivative & ENEL (CAGT) & CAGT & 1994 & .05 \\
\hline $\begin{array}{l}\text { Nuovo Pignone } \\
\text { Estimate }\end{array}$ & Nuovo Pignone & Various & $\begin{array}{l}1992 \\
1991\end{array}$ & $\begin{array}{l}4.85 \\
3\end{array}$ \\
\hline
\end{tabular}


Japan

\begin{tabular}{|l|l|l|l|l|}
\hline Project & $\begin{array}{l}\text { Funding } \\
\text { Source }\end{array}$ & Performer & Dates & $\begin{array}{l}\text { Funding Level } \\
\text { US\$ (million) }\end{array}$ \\
\hline New Sunshine & Federal Govt. & Various & 1993 & 23.4 \\
\hline Various & Kawasaki & Various & 1994 & $38.9^{*}$ \\
& & & 1993 & $29.4^{*}$ \\
& & & 1992 & $25.6^{*}$ \\
\hline Various & Tokyo Elect. & Various & 1993 & $37.9^{*}$ \\
& Power Co. & & 1992 & $37.5^{*}$ \\
\hline Various & Tohoku Elect. & Various & 1994 & $0.7^{*}$ \\
& Power Co. & & 1993 & $0.6^{*}$ \\
\hline Various & Tokyo Gas & Various & 1994 & 8.8 \\
& & & 1993 & 8.1 \\
\hline Various & Hitachi & Various & 1993 & $15.7^{*}$ \\
\hline Various & IHI & Various & 1993 & NA \\
\hline Various & Toshiba & Various & 1993 & NA \\
\hline Various & Mitsubishi & Various & 1993 & $3.6^{*}$ \\
\hline
\end{tabular}

* Estimated levels of expenditures

Netherlands

\begin{tabular}{|l|l|l|l|l|}
\hline Project & $\begin{array}{l}\text { Funding } \\
\text { Source }\end{array}$ & Performer & Dates & $\begin{array}{l}\text { Funding Level } \\
\text { US\$ (million) }\end{array}$ \\
\hline Various & $\begin{array}{l}\text { Federal } \\
\text { Government }\end{array}$ & Various & $1991-$ Present & 3 \\
\hline Various & $\begin{array}{l}\text { Priv. Industry } \\
\text { \& Utilities }\end{array}$ & Various & $1991-$ Present & 2 \\
\hline
\end{tabular}

Norway 


\begin{tabular}{|l|l|l|l|l|}
\hline Project & Funder & Performer & Dates & Funding Level \\
\hline None & $\begin{array}{l}\text { Federal } \\
\text { Government }\end{array}$ & NA & NA & None \\
\hline
\end{tabular}

\section{Sweden}

\begin{tabular}{|l|l|l|l|l|}
\hline Project & $\begin{array}{l}\text { Funding } \\
\text { Source }\end{array}$ & Performer & Dates & $\begin{array}{l}\text { Funding Level } \\
\text { US\$ (million) }\end{array}$ \\
\hline None & $\begin{array}{l}\text { Federal } \\
\text { Government }\end{array}$ & Various & NA & None \\
\hline Various & $\mathrm{ABB}$ & $\mathrm{ABB}$ & 1993 & $116^{*}$ \\
& & 1992 & $69.5^{*}$ \\
\hline
\end{tabular}

* Estimated funding levels

\section{Switzerland}

\begin{tabular}{|l|l|l|l|l|}
\hline Project & $\begin{array}{l}\text { Funding } \\
\text { Source }\end{array}$ & Performer & Dates & $\begin{array}{l}\text { Funding Level } \\
\text { US\$ (million) }\end{array}$ \\
\hline None & $\begin{array}{l}\text { Federal } \\
\text { Government }\end{array}$ & NA & NA & None \\
\hline Various & ABB & ABB & 1993 & 116 \\
& & & 1992 & 69.5 \\
\hline
\end{tabular}

\section{United Kingdom}

\begin{tabular}{|l|l|l|l|l|}
\hline Project & $\begin{array}{l}\text { Funding } \\
\text { Source }\end{array}$ & Performer & Dates & $\begin{array}{l}\text { Funding Level } \\
\text { US\$ (million) }\end{array}$ \\
\hline Various & Government & NA & NA & None \\
\hline Various & Rolls Royce & Rolls Royce & 1993 & $328^{*}$ \\
& & & 1992 & $297^{*}$ \\
\hline
\end{tabular}


United Kingdom

\begin{tabular}{|l|l|l|l|l|}
\hline Project & $\begin{array}{l}\text { Funding } \\
\text { Source }\end{array}$ & Performer & Dates & $\begin{array}{l}\text { Funding Level } \\
\text { US\$ (million) }\end{array}$ \\
\hline Various & $\begin{array}{l}\text { GEC Alsthom } \\
\text { European Gas } \\
\text { Turbines }\end{array}$ & $\begin{array}{l}\text { European Gas } \\
\text { Turbines }\end{array}$ & 1993 & $17.5^{*}$ \\
\hline Various & $\begin{array}{l}\text { United } \\
\text { Technologies } \\
\text { (Pratt Whitney) }\end{array}$ & Pratt Whitney & 1993 & $19.9 *$ \\
\hline
\end{tabular}

* Estimated levels of expenditures

\section{United States}

\begin{tabular}{|l|l|l|l|l|}
\hline Project & $\begin{array}{l}\text { Funding } \\
\text { Source }\end{array}$ & Performer & Dates & $\begin{array}{l}\text { Funding Level } \\
\text { USS (million) }\end{array}$ \\
\hline Various & $\begin{array}{l}\text { Department of } \\
\text { Energy } \\
\text { ATS Program } \\
\text { Funding }\end{array}$ & Varous & 1994 & 32 \\
\hline Various & GRI & Various & 1996 & 450 \\
\hline Various & EPRI & Various & NA & $\begin{array}{l}(4.1 \\
(4.5)\end{array}$ \\
\hline Various & Westinghouse & Same & 1993 & 2.3 \\
& & & 1995 & NA \\
\hline Various & Industries & Same & 1993 & $9.8^{*}$ \\
& & 1992 & $9.7^{*}$ \\
\hline
\end{tabular}




\section{United States}

\begin{tabular}{|l|l|l|l|l|}
\hline Project & $\begin{array}{l}\text { Funding } \\
\text { Source }\end{array}$ & Performer & Dates & $\begin{array}{l}\text { Funding Level } \\
\text { US\$ (million) }\end{array}$ \\
\hline Various & $\begin{array}{l}\text { General } \\
\text { Electric }\end{array}$ & Same & 1993 & $442.4^{*}$ \\
\hline Various & Solar Turbines & Same & 1992 & $458^{*}$ \\
& & & 1993 & $20.2^{*}$ \\
& & & $19.3^{*}$ \\
\hline
\end{tabular}

* Estimated levels of expenditures 


\section{Appendix D. Exchange Rates and Purchasing Power Parities}

Table D.1, which follows, shows the exchange rates and purchasing power parities for the selected countries in country currency units per U.S. dollar.

Table D.1 Exchange Rates and Purchasing

Power Parities

\begin{tabular}{|c|c|c|}
\hline Country & Exchange Rate & Purchasing Power Parity \\
\hline Australia & 1.35 & 1.33 \\
\hline Belgium & 32.80 & 38.80 \\
\hline Canada & 1.38 & 1.25 \\
\hline Denmark & 6.26 & 9.30 \\
\hline Finland & 5.24 & 6.46 \\
\hline France* & 5.44 & 6.56 \\
\hline Germany & 1.60 & 2.13 \\
\hline Italy & $1,595.00$ & $1,523.00$ \\
\hline Japan & 99.75 & 187.00 \\
\hline Netherlands & 1.79 & 2.17 \\
\hline Norway & 6.95 & 9.22 \\
\hline Sweden & 7.78 & 10.10 \\
\hline Switzerland & 1.54 & 2.22 \\
\hline United Kingdom & 0.66 & 0.64 \\
\hline
\end{tabular}

* Example: There are 5.44 french francs for every U.S. dollar utilizing exchange rates. 


\section{Appendix E. Further Reading}

Ademe, Programme de recherche et developpement 1992-1996, Paris, March 1993.

A.F. Al-Shaikhly, Aero and Industrial Technology Inc., T.I. Mina, European Gas Turbines, M.O. Neergaard, Sydkraft Konsult, Development of a Dual Fuel LBTU Gas/Diesel Burning combustion System for a 4.2 MW Gas Turbine, June 13-16 1994.

A.J. Appleby, Texas A\&M University, F.R. Foulkes, University of Toronto, Fuel Cell Handbook, Van Nostrand Reinhold Publishing, 1989.

Allied Signal, Annual Report, 1993.

Allison Gas Turbine, Power of Excellence 1915-1990.

A.J. Scalzo, R.L. Bannister, M. DeCorso, G.S. Howard, Evolution of Heavy-Duty Power Generation and Industrial Combustion Turbines in the United States, Westinghouse Electric Corporation, June 13-16 1994.

Asea Brown Boveri, Ltd., Annual Report, Geneva, Switzerland, 1993.

Association technique de l'industrie du gaz en france, Mediagaz bulletin, September 1994.

Bundesministerium fur Wirtschaft, Energy Policy for the United Germany, Berlin, 1993.

Bundesministerium fur Forschung und Technologie, Energieforschung und Energietechnologien, Berlin, Germany, April 1993.

Bundesministerium fur forschung und Technologie, Bundesbericht Forschung 1993, Berlin, Germany, July 1993.

Caterpillar, Inc., The Global Competitor, Annual Report 1993.

Centre national De La Recherche Scientifique (CNRS), Rapport D'Activite 1993.

Chubu Electric Power Company, Inc., Annual Report, 1994.

Cooper Industries, Cooper Industries, February 1994.

Cooper Industries, Annual Report, 1993. 
David Brooks, Nevile Henderson, Jeffery Masters, British Gas, British Gas and Cogeneration.

Directorate of Intelligence, Central Intelligence Agency, Handbook of International Economic Statistics 1993, Washington D.C., September 1993.

Donald F. Borden, William H. Day, Daniel H. Lord, Turbo Power \& Marine Systems, Aeroderivative Gas Turbines for Cogeneration, June 1994.

Donald F. Borden, Turbo Power \& Marine Systems, FT8 Mechanical Drive Gas Turbines for The Oil \& Gas Industry, September 1994.

Donald W. Geiling, Proceedings of the Joint Contractors Meeting: FE/EE Advanced Turbine Systems Conference FE Fuel Cells and Coal-Fired Heat Engines Conference, USDOE, DE93011308, August 1993.

Douglas J. Smith, Fuel Cells hold promise for electric power generation, Power Engineering, February 1994.

Dresser Industries, Inc. Annual Report, 1993.

Electric Power Research Institute (EPRI), Molten Carbonate Fuel Cells at M-C Power Corporation, FPS Developments, Summer 1992.

Electricite de France, Annual Report, Paris, France, 1993.

Energy Research Corporation, ERC Review, Fall 1994.

Energy Research Corporation, Annual Report, 1993.

European Gas Turbines, Annual Report, 1993-1994.

Executive Office of the President of the United States, Budget of the United States Government, Fiscal Year 1992.

Executive Office of the President of the United States, Historical Tables, Budget of the U.S. Government, Fiscal Year 1994.

Federal Ministry for Research and Technology (Germany), Report of the Federal Government on Research 1993 (abridged version), July 1993.

Federal Ministry for Research and Technology (Germany), Renewable Energy, Dec. 1992.

Fuel Cell Commercialization Group, FCCG Update, Spring 1994. 
Fuel Cell Commercialization Group, Fuel Cell Planning.

Fuel Cell Commercialization Group, Santa Clara Demonstration Project Overview, March 1994.

GEC Alsthom, Annual Report, 1992-1993.

Gas Research Institute (GRI), 1995-1999 Research and Development Plan and Research and Development Program, April 1994.

Gas Turbine World, Pequot Publishing, Inc., July-August 1992.

Gas Turbine World, Pequot Publishing, Inc., May-June 1994.

Gas Turbine World, Pequot Publishing, Inc., July-August 1994.

Gas Turbine World, Pequot Publishing, Inc., September-October 1994.

General Electric Company, 1993 Annual Report.

General Electric Company, Source Book.

Helen Fedor, Robert Garian, Research Support on Foreign Funding of Fossil Fuel and Alternative Energy R\&D, Library of Congress, August 1994.

Hitachi, Outline of Hitachi 1994.

Hitachi, Annual Report, Year ended March 31, 1994.

International Energy Agency (IEA), Organization for Economic Co-operation and Development (OECD), The Role of IEA Governments in Energy, Paris, France,1992.

International Energy Agency(IEA), Organization for Economic Co-operation and Development (OECD), International Conference on Emerging Natural Gas Technologies, Proceedings, October 1990.

International Energy Agency(IEA), Organization for Economic Co-operation and Development (OECD), Natural Gas Technologies: Energy Security, Environment and Economic Development, Proceedings, November 1993.

International Energy Agency(IEA), Organization for Economic Co-operation and Development (OECD), Natural Gas Technologies: Energy Security, Environment and Economic Development, Proceedings, November 1993.

Ingersoll-Rand, Annual Report, 1993. 
ITT Corporation, Annual Report, 1993.

Jason Makansi, Are fuel cells heir apparent to the gas turbine?, Power, McGraw Hill, June 1994.

Kansai Electric Power Company, Inc., Current Information 1994, annual report 1994.

Kawasaki Heavy Industries, Ltd., The Power of Kawasaki, annual report 1994.

K. K Matsuzaki, H. Matsuzaki, K. Aouama, S. Aoki, S. Mandai, Development Study of $1500^{\circ} \mathrm{C}$ Class High Temperature Gas Turbine, Tohoku Electric Co., Mitsubishi Heavy Industries, Ltd., June 3-6, 1991.

Manville J. Mayfield, Fuel Cells-Almost There, Electric Perspectives, Sept.-Oct., 1994.

Martin T. Samson, European Gas Turbines, Package Design of the RLM 1600 Gas Turbine, May 24-27, 1993.

M-C Power, Power Generation for Tomorrow and the 21st Century, Annual Report.

Mitsubishi Heavy Industries, Ltd., Mitsubishi Power Systems, First $220 \mathrm{MW}$-Class HighEfficiency Model $701 F$ Gas Turbine Started Operation, July 1992.

Mitsubishi Heavy Industries, Ltd., Annual Report 1993.

Mitsubishi Heavy Industries, Mitsubishi Gas Turbines Application Summary.

National Research Council Canada, Program Report: Wind Energy Research and Development a the National Research Council of Canada 1975-1985, October 1986.

National Science Foundation, National Patterns of R\&D Resources: 1992, NSF 92-330, October 1992.

National Science Foundation, International Science and Technology Data Update: 1991, NSF 91-309, April 1991.

Nuovo Pignone, Annual Report 1992.

Office of Energy R\&D, Natural Resources Canada, Plan of the Program of Energy Research and Development, April 1994.

Organization for Economic Co-operation and Development (OECD), Main Economic Indicators, September 1994. 
Organization for Economic Co-operation and Development (OECD), OECD Science and Technology Indicators, Paris, France, 1989.

ONSI, Fuel Cell Power Generation... The Natural Choice for On-Site Energy Service, Information Package, January 1995.

R.C. Hodrien, G. Fairburn, British Gas, Power into the 21st Century, November 1993.

R.J. Carpenter, J.A. Parsons, J. Person, British Gas, Small scale CHP-Harnessing technology to meet market needs, November 1993.

R.J. Carpenter, A.L. Dicks, J.A. Parsons, British Gas, The development of fuel cells for power generation and combined heat and power, November 1990.

R.L. Bannister, N.S. Cheruvu, D.A. Little, G. McQuiggan, Development Requirements for an Advanced Gas Turbine System, Westinghouse Electric Corporation, June 13-16, 1994.

Richard R. Woods, Steve Huval, IMHEX Fuel Cell Commercialization, M-C Power Corporation, Stewart and Stevenson Services, Inc.

Robert Farmer, Typhoon two shaft into's as 6,500 hp mechanical driver, Gas Turbine World, March-April 1994.

Rolls Royce, Annual Report, 1993.

Siemens, Annual Report, 1993.

Solar Turbines, Gas Turbine Systems.

Stacey Hobart, The commercialization of a Fuel Cell, Public Power, Jan.-Feb. 1994.

Sydkraft, The Bio Power Plant in Varnamo; A milestone in energy technology.

The Department for Enterprise, New and Renewable Energy: Future Prospects in the UK, March 1994.

The Department for Enterprise, Energy Technologies for the UK; An Appraisal of UK Energy Research, Development, Demonstration \& Dissemination, May 1994.

T.I. Mina, G.S. Robinson, A. Seamer, European Gas Turbines, Gas Turbine Systems Development to Meet the Requirements of A Dual Fuel Biomass/Diesel Oil Application.

Tohoku Electric Power Company, Leading Japan's Development in the 21st Century. 
Tohoku Electric Power Co. Demonstrating a Phosphoric Acid Fuel Cell Generating System.

Tohoku Electric Power Co. Perspectives on Energy Supply Dynamics, Ann Rept, 1994.

Tokyo Electric Power Co. Statistical Review, April 1993-March 1994.

Tokyo Electric Power Co. Towards Tomorrow's Technology, 1992-1993.

Tokyo Gas, Research \& Development Program, 1994-1998.

Tokyo Gas, Annual Review, 1994.

Tokyo Electric Power Company, An Overview, April 1993-March 1994.

Tokyo Electric Power Company, New Energies Park Guide.

Tokyo Electric Power Company, $\mathrm{CO}_{2}$ Removal Technology Laboratory at the Yokosuka Thermal Power Station.

UNESCO, Statistical Yearbok 1993, 1993.

United Technologies, Annual Report, 1993.

United Technologies, Turbo Power; FT8 Gas Turbines.

U.S. Department of Commerce, Statistical Abstract of the United States 1993, 113th ed.

U.S. Department of Energy, The Domestic Natural Gas and Oil Initiative, Dec. 1993.

U.S. Department of Energy, Natural Gas Strategic Plan and Multi-Year Program Crosscut Plan FY 1994-1999, December 1993.

Westinghouse Electric Corporation. Steam cooled $60 \mathrm{~Hz}$ W501G generates $230 \mathrm{MW}$, Aug., 1994.

Westinghouse Electric Corporation, A combined cycle designed to achieve greater than 60 percent efficiency, October 1994.

Westinghouse Electric Corporation, Hot Gas Cleaning makes promising progress, Modern Power Systems, September 1994.

Westinghouse Electric Corporation, Business Portfolio, 1994.

Westinghouse Electric Corporation, How will we achieve success?, annual report, 1993. 
Westinghouse Electric Corporation, Powering The Future, 1992.

Westinghouse Electric Corporation, Solid Oxide Fuel Cell, October 1992. 